A. की

$-3 \%$ of 40.960 of

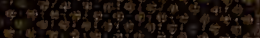

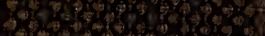

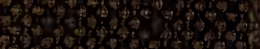

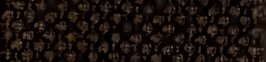

30 .

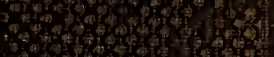

tho

P.9

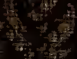

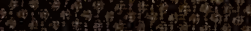

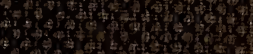

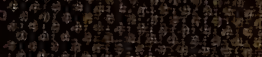

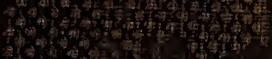

4. भी
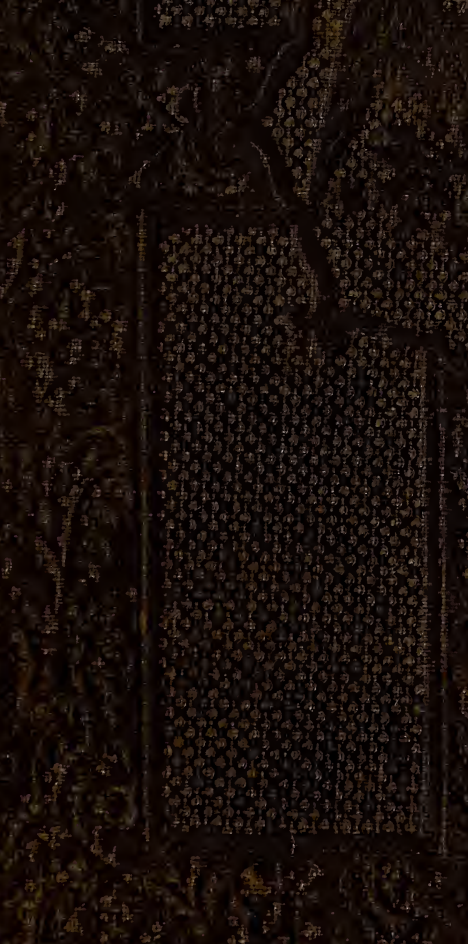

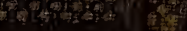

की

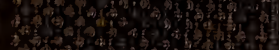

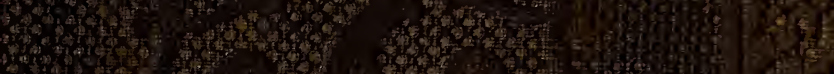

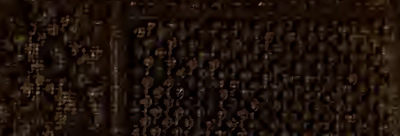

ariat (⿻)丨तs

5. 3is a

郭

का:

chasde.

Deprest

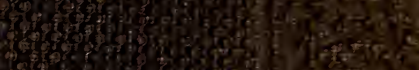

(19)

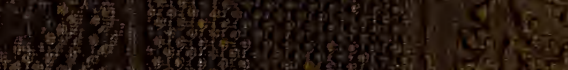

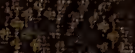

(1)

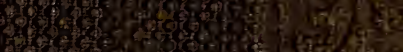

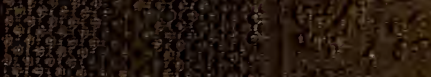

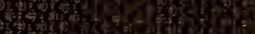

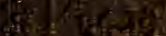

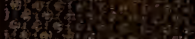

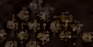

कos? whe

axion

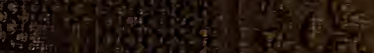
thot.

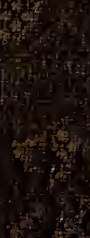

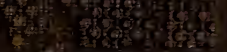

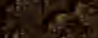

ic ene?

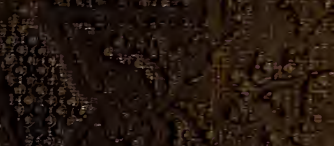
that

and int

2.14 6at

(2)

(1)

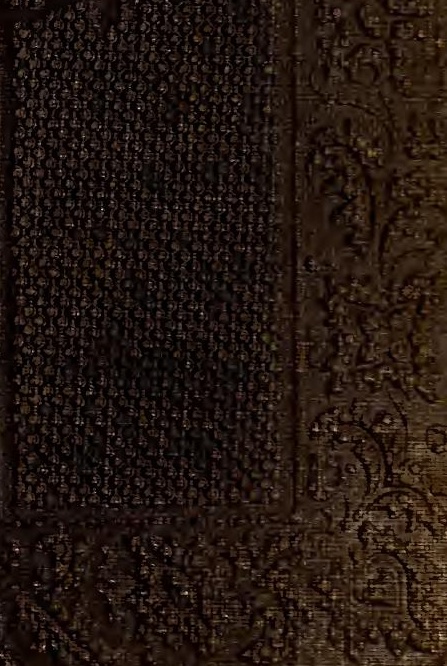








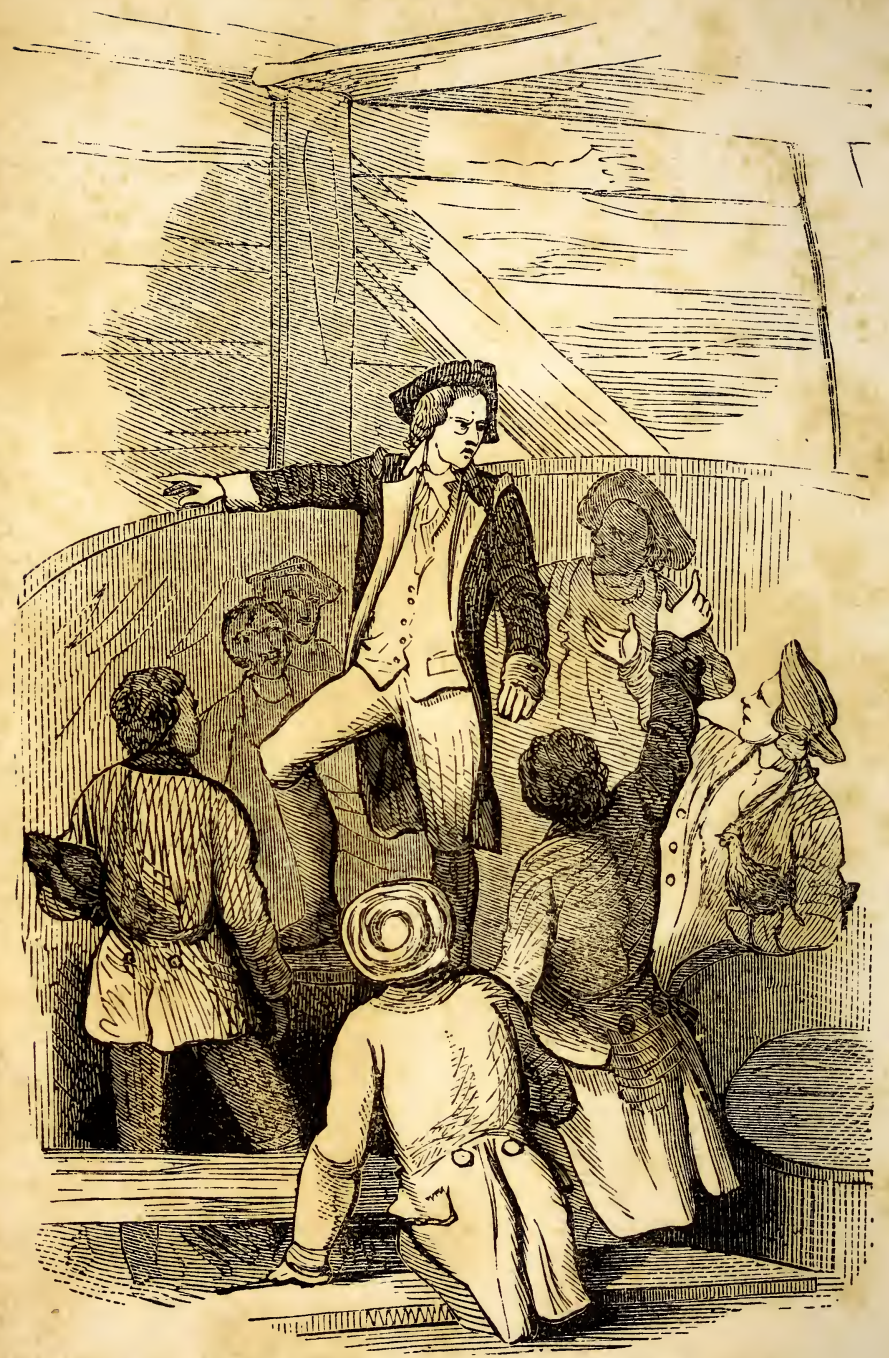

ORIGIN OF SEMPTFR'S SOUBRIQUET OF THE GAME COCK.-PAGE 809. 


\section{LVES OF}

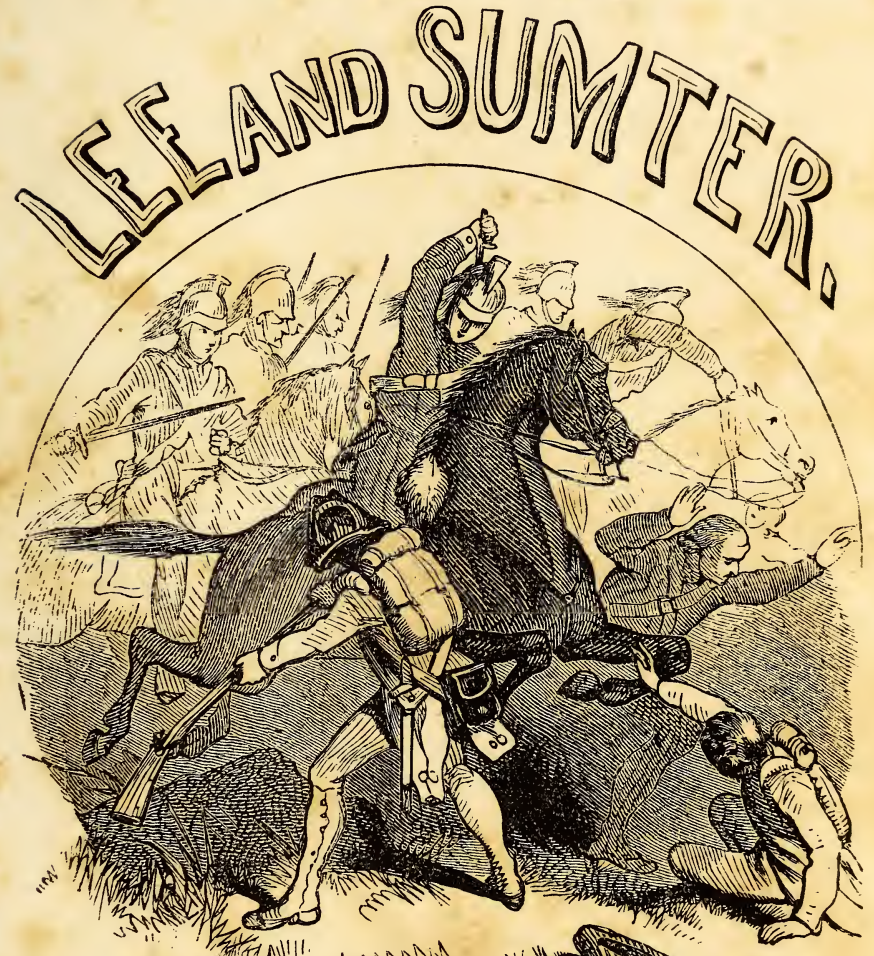

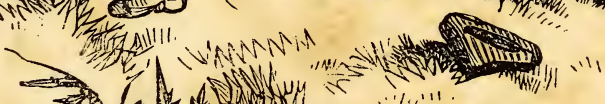

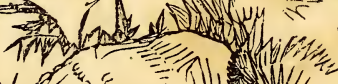

W.1",

i"'! $/ 2$

NWWis/s 


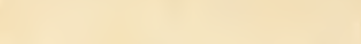

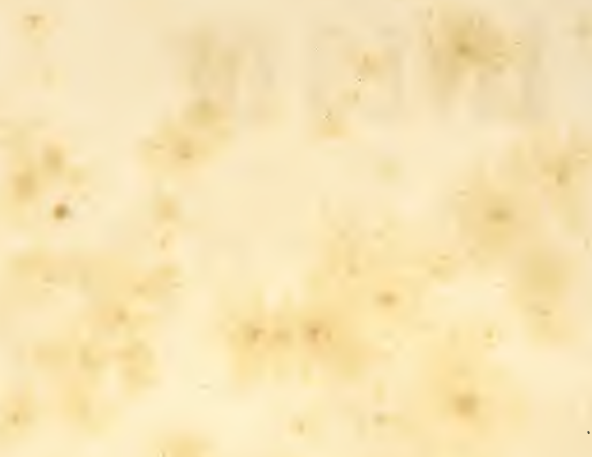

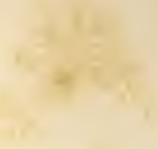

5 


\section{${ }_{207}$ \\ L 5 H $3 X$ \\ 1.859 \\ L I F E O F \\ NMAH \\ MAJOR GENERAL HENRY LEE,}

COMMANDER OF LEE'S LEGION

IN THE REVOLUTIONARY WAR,

AND SUBSEQUENTLY

\section{GOVERNOR OF VIRGINIA;}

TO WHICH IS ADDED THE

LIFE OF

GENERAL THOMAS SUMTER

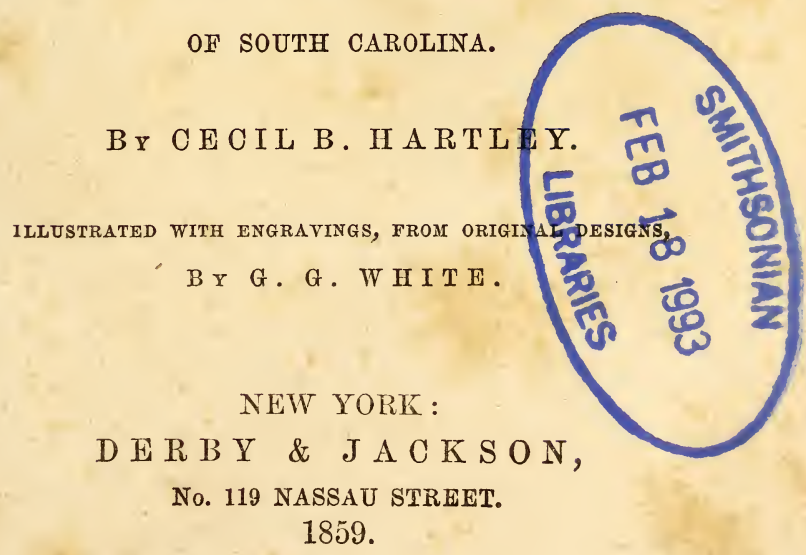


Entered according to the Act of Congress, in the year 1859, by G. G. EVA N S, in the Clerk's Office of the District Court for the Eastern District of Pennsylvania. 


\section{P RE F A CE.}

General Henry Lee was one of the most useful and

- conspicuous officers in the Revolutionary war. He was the intimate personal friend of Washington; and after the revolution he was equally conspicuous in political affairs, rising to the office of governor of the state of Virginia. Yet we are not aware that any extended biography of General Lee has been published since his decease. His well known work, "Memoirs of the War in the Southern Department of the United States," in two octavo volumes published in 1812, furnishes details of a portion of his military life; and we have drawn freely from it in our account of his services in the South; but our other materials, for the present biography, had to be drawn from a variety of sources. We have endeavored to do the subject justice; and we trust that our humble efforts will serve to place before the country in their true light the services of one of the bravest, most generous, and 
chivalrous of all the heroes, who served in the war of the Revolution.

General Thomas Sumter was also a very distinguished officer in the same war. Unlike Lee, his revolutionary services were confined to the South, but on this field they were of inestimable value. He was the first of the partisan chieftains who openly took the field after the fall of Charleston; and for a considerable period he was considered by Lord Cornwallis the most troublesome of all his opponents. In heroic daring he was unsurpassed by any of the partisan officers; and he was the first to defeat the redoubtable Tarleton, who had rendered himself the terror of the South by his activity, boldness, and cruelty. After the close of the war, General Sumter represented South Carolina in the House of Representatives and the Senate of the United States.

We have endeavored to give a clear and impartial account of the lives and services of these eminent patriots in the following pages; which we trust will be read with interest by their countrymen of the present time. 


\section{CON TEN T S.}

\section{LIFE OF MAJOR GENERAL HENRY LEE.}

\section{CHAPTER I.}

Birth of Henry Lee-Private instruction at home-Goes to Princeton College-Is graduated-Takes charge of his father's private business during his absence on public affairs-His remarkable abilities Takes an interest in military affairs-Appointed Captain in Bland's regiment of cavalry-Great want of cavalry in the army under Washington-Bland's regiment joins the main army-Engaged in the battle of Brandywine-Washington's retreat after the battle-Lee sent on detached service with Colonel Alexander Hamilton-Singular adventures of the two officers-Their life-long friondship

\section{CHAPTER II.}

Position of Lee favorable to advancement-His attention to discipline -His conduct noticed by Washingion-Events after the battle of Brandywine-Lee commands Washington's body guard at the battle of Germantown-Situation of the American army at Valley Forge-Of the British army in Philadelphia-Lee employed in harassing the British lines, and cutting off foraging and marauding parties-Attempt to surprise him-Admirable defence-Promoted to be Major, and to command an independent partisan corps-Correspondence with Washington........................................................

\section{CHAPTER III.}

Separation of Lee's corps from Bland's regiment-Lee's attack on, and dispersion of, a detachment of Donop's Hessian yagers-Confidence reposed in Major Lee by Washington-Attack on, and surprise of, Paulus Hook by a detachment under Lee's command-Washington's praise of Lee-Thanks of Congress, and a gold medal voted to LeePromotion of his officers, and pecuniary rewards to his men-Lee sent on a confidential mission to Count D'Estaing by Washington... 
Lee's legion placed by Washington under marching order for the South-Sets out-Stopped, and ordered back to New Jersey by Washington-Arrives, and ordered to take post in rear of the army -Knyphausen's marauding inroad into Jersey-Lee's active and useful services in the battle of Springfield, described by General Greene-Lee again ordered on important and confidential service by Washington, to take the command at Monmouth, to await the arrival of the French fleet.

\section{CHAPTER V.}

Arnold's treason-Lee's corresponderce with Washington on the suspicions against St. Clair and other officers-Lee engages his sergeant major, Champe, to desert, go to the British camp, and seize Arnold and bring him off alive-Lee's own interesting narrative of the whole affair.

\section{CHAPTER VI.}

Congress retains Lee's legion in remodeling the army-Lee advanced to the rank of Lieutenant Colonel-Ordered to join the Southern army under General Greene-Washington's opinion of Lee-General Greene proceeds to Richmond and Hillsborough-Account of North Carolina-Greene joins the army at Charlotte-Gates resigns the command to Greene, and proceeds to Richmond-Noble conduct of the Virginia Legislature towards him-Condition of the army-Character and appearance of General Greene-His disposition of the forces-Colonel Washington's successful stratagem at Rugeley's farm-Army leave Charlotte-Greene takes a position on the Pedee near Cheraw Hill..

\section{CHAPTER VII.}

Tee's legion joins the army under Greene-Surprises GeorgetownBattle of Cowpens-Cornwallis prepares to pursue Greene's army by destroying a part of his baggage and stores-Greene joins Morgan and brings forward his detachment to the main armyThe pursuit commences-Defeat of Davidson-Greene passes the Yadkin-Lee with his legion, joins Greene's main army-Placed between the retreating and advancing armies-Lee dissuades Morgan from leaving the army-But Morgan retires on account of ill health 


\section{CHAPTER VIII.}

Colonel Williams appointed in Morgan's place-Severe duty of Lee's legion and the corps of Williams-An alarm-Lee interrupted at his breakfast, and sent off on duty-Gives his bugler's horse to a countryman-Attacks Tarleton's cavalry-Defeats them-No quarter-British Captain Miller saved by Lewis-Lewis reprimanded by Lee, who determines to sacrifice the captain-How he escapes death-Miller writes an account of this to the British army-Effect of his letter...........................................................

\section{CHAPTER IX.}

Lee again interrupted at his breakfast--Narrow escape of Lee and his legion-Near approach of the enemy-Night march-Great alarm of Lee for Greene's safety-He comes on Greene's deserted camp-Greene passes the Dan-Williams and Lee pass the DanEnd of the retreat-Its immense importance-The salvation of the Southern States-General remarks on the retreat........................

\section{CHAPTER $\mathrm{X}$.}

Cornwallis's proclamation-Its effect-Greene determines to harass him and prevent his gaining recruits in North Carolina-Pickens and Lee ordered to recross the Dan on this service-Greene passes a night in their camp-They pursue Tarleton-His force-Come upon his deserted quarters-Lee and Pickens assume the character of loyalist reinforcements-Success of the stratagem-They hear of Pyle's detachment of royalists-They entrap Pyle's detachment, and are about to capture it, when an accident brings on an action and Pyle's men are sacrificed-Pickens and Lee pursue Tarleton's regiment-Are joined by Colonel Preston and his Virginia militiaOrder of advance-Tarleton recalled by Cornwallis-His narrow escape from Lee and Pickens.

\section{CHAPTER XI.}

General Greene recrosses the Dan-Cornwallis leaves HillsboroughWilliams, Pickens, and Lee, detached to harass Cornwallis-They encounter and baffle Colonel Webster-Encounter with Colonel Webster near Wetzel's mill-His extraordinary escape from Lee's sharpshooters. 


\section{CHAPTER XII.}

Greene's army reinforced-Lee harasses Cornwallis-Attempts to cut off an escort with baggage-Adventures of a night-Lost in the woods-Cornwallis's commentary-Cornwallis's approach towards Guilford Courthouse-Lee's encounter with Tarleton's cavalryGeneral Greene prepares for battle with Cornwallis.

\section{CHAPTER XIII.}

Battle of Guilford Courthouse-Cornwallis's army greatly weakened by this action-Greene retreats to the Iron Works-Loss of the Americans in the battle-Loss of the British-Courage of the British troops-Desperate condition of Cornwallis-He retreats to Cross Creek-Greene pursues him-Cornwallis arrives at WilmingtonGreene gives over the pursuit-Greene resolves to carry the war into South Carolina-Cornwallis decides to proceed to Virginia....... 154

\section{CHAPTER XIV.}

Lee ordered to join Marion on the Pedee-Movements of General Greene-Battle of Hobkirk's Hill-Lord Rawdon determines to evacuate Camden-Exultation of Greene-Lee and Marion capture Fort Watson-Colonel Watson joins Lord Rawdon-They menace Greene, but do not attack him-Lee and Marion kesiege and capture Fort Motte-Noble conduct of Mrs. Motte-Lee proceeds to Fort Granby-General Sumter captures the post at Orangeburgh.... 165

\section{CHAPTER XV.}

Position of Fort Granby-Lee lays siege to it-Summons the garrison -Negotiations-Capitulation of Fort Granby-The garrison retires -Public stores surrendered-Lee apprises General Greene of his success-Greene visits him, and commends the conduct of the legion -Lord Rawdon retreats to Monk's Corner, relinquishing his line of posts-Great success of the Americans-Two States recovered in one month

\section{CHAPTER XVI.}

Lee ordered to join Pickens in the siege of Augusta-Operations of Major Rudulph-Lee reaches Augusta-He hears of the Indian present of supplies, and determines to seize it-Sufferings of the troops on 
the march-Lee obtains the supplies-He sends Mrjor Eggleston to summon Brown to surrender Augustu-Union of the whole besieging force-Lee defeats Grierson, and captures one of the forts-Renewal of intercourse-Mayham tower built-Brown makes a sally, and is repulsed with a severe loss-Brown's stratagem for burning the tower-Its failure--The deserter-The explosion-Brown surrenders Augusta-Lee gaves Brown's life, which is threatened by the Georgians-Pickens remains at Augusta-Lee joins General Groene at Ninety-six.

\section{CHAPTER XVII.}

Siege of Ninety-Six-Kosciusko chief engineer-His blunders-Lee placed in command on the left, besieges the stockade-Resisted by continual night sallies-Greene receives intelligence of Lord Rawdon's approach-Orders Marion and Pickens to delay Rawdon, and retains Lee with him at Ninety-Six-Lee attempts to burn the stockade fort, but fails-Rawdon's messenger reaches Cruger-Active ope-. rations-Near approach of Lord Rawdon-Greene resolves to storm the fort of Ninety-Six-The storming-Lee and Campbell lead the assault-Desperate conflict in the Star 'Fort-Lee's legion captures the stockade fort- $\mathrm{H}_{0}$ is ordered by Greene to hold the stockadeLosses-Retreat ordered-Sad reverso--Groene's equanimity

\section{CHAPTER XVIII.}

Lord Rawdon arrives at Ninety-Six-Pursues Greene, who retreatsRawdon returns to Ninety-Six-Greene offers battle which is declined by Rawdon-Greene detuches Sumter, Marion, and Loe to the lower posts-Lee's suocess at Dorchester-Hampton's success-Sumter approaches Monk's Corner-Retreat of Coates-Lee charges and captures the British rear guard-Affair at Quinby bridge-Retreat of Coates-Separation of the partisan leaders-Eminent character and services of Lee and his legion

\section{CHAPTER XIX.}

Vindictive character of the war in the South-Case of Colonel HayneOf Colonels Brown and Grierson-General Greene discourages this spirit-Greene reinforced-Lord Rawdon sails for England-Succeeded by Colonel Stuart-Greene resolves to attack him-Stuart retires to Eutaw-Greene follows him-Battle of Eutaw-British driven off the field-Take shelter in a brick-house-Attack of Lee's legion on the house-Retire-Misfortunes of Colonel Washington's 
corps-Result of the battle-A British standard, and a gold medal voted by Congress to Greene-Stuart retreats to Monk's CornerGreene retires to the high hills of Santee.

\section{CHAPTER XX.}

Lee is sent to headquarters-Witnesses the surrender of CornwallisReturns to General Greene with despatches from WashingtonWayne's operations in Georgia-Contests with the Indians-Final reconquest of Georgia-Wayne rejoins Greene-Greene's operations in South Carolina-Final reconquest of South Carolina-Death of Colonel Laurens-Lee's attempt on St. John's Island-He obtains leave of absence, and returns to Virginia.

\section{CHAPTER XXI.}

Colonel Lee's marriage-Neglect of his services by Congress-Favorable opinion entertained of him by Greene and Washington-His important services-Lee elected a member of the Continental Congress -His correspondence with Washington-Death of General Greene.. 251

\section{CHAPTER XXII.}

Correspondence of Colonel Lee and General Washington on the subject of the latter accepting the office of President of the United States..... 256

\section{CHAPTER XXIII.}

Colonel Lee chosen a member of the Convention of Virginia for ratifying the Constitution of the United States-His earnest support of the Constitution in the Convention-Colonel Lee chosen a member of the House of Delegates of Virginia-Offered a command in the army to act against the Indians-Declines-Chosen Governor of Virginia-Proposed as commander of the army against the northwestern Indians-Correspondence with President Washington on this subject.

\section{CHAPTER XXIV.}

Washington's proclamation of neutrality-Lee's opinion on it-His letter to Washington-Death of Mrs. Lee-He wishes to take military service in France-His letter to Washington on the subjectWashington's answer. 


\section{CHAPTER XXV.}

Lee's opiniun on Washington's system of neutrality-Genet's conduct -Correspondence of Washington and Lee on the subject-Origin 0. the whiskey insurrection in Pennsylvania-Washington determines to suppress it-Raises an army, and gives Lee the command in chief with the rank of Major General-Washington's instructions to LeeSpeedy suppression of the revolt

\section{CHAPTER XXVI.}

War with France-Army to be raised provisionally-Washington names Lee as one of the Major Generals-Lee elected to CongressDeath of Washington announced-Lee writes the resolutions moved in Congress by General Marshall-Appointed by Congress to deliver the Funeral Eulogy on Washington-Serves in Congress during Adams' administration-Retires to private life......................... 286

\section{CHAPTER XXVII.}

Private life--Pecuniary embarrassment-Literary pursuits-Memoirs -The Baltimore mob-General Lee wounded, and General Lingan killed, in defending the liberty of the press-General Lee's health ruined-He goes to the West Indies-Returns-Visits Mrs. Shaw in Georgia-Dies on her plantation-Character of General Lee.

\section{LIFE OF MAJOR GENERAI, THOMAS SUMTER.}

\section{CHAPTER I.}

Birth of General Sumter-Services in the old French war-Distinguished by Lord Dunmore-At the defeat of General Braddock-Services in the Cherokee war-Goes to England with OcconostotahReturns to the Indian country-Arrests a French Emissary-Takes an active part in opposing the oppression of Great Britain-Appointed Lieutenant Colonel-Stationed in the interior-Battle of Fort Moultrie-Second Cherokee war-Fall of Charleston-Flight of patriots-Burning of Sumter's house-Sumter raises recruits-Origin of his soubriquet of the "Game Cock"-Recruits-Arms...............

\section{CHAPTER II.}

Condition of the Carolinas-Cornwallis and Rawdon's position-Gates advancing-Marion, Sumter, Pickens-Movements of Rawdon-Sumter assaults the British fort at Rocky Mount-Davie's success at Hanging Rock-Sumter's attempt on Rocky Mount foiled by the misconduct of his men-He retreats to his asylum 
Movements of Gates and Rawdon-Gates informed by Sumter of a convoy of stores from Ninety-Six-Sends a reinforcement to him-Sumter captures the convoy-Errors of Gates-Cornwallis determines to fight him-His dispositions for battle-Night encounter-Gates prepares for battle-Battle of Camden-Flight of the militia-Brave resistance of the continentals under Baron de Kalb, and of the North Carolinians-Death of De Kalb

\section{CHAPTER IV.}

Gates informed of Sumter's success-Movements of Major Davie-He informs Sumter of Gates's defeat-Sumter retreats rapidly-Pursued and surprised by Tarleton-Sumter escapes with part of his forceComments on Tarleton's conduct-Gates retires to Salisbury-Afterwards to Hillsborough

\section{CHAPTER V.}

Sumter again in the field-Operations of the parties and leaders in the South-Position of the British army-Operntions of Marion and Sumter-Turleton foiled by Marion--Major Wemyss defeated by Sumter - Tarleton sent against Sumter-Battle of Blackstock Hill-Total defent of Tarleton by Sumter-Sumter severely wounded, and compelled to quit active service-Operations of Marion-State of the Southern country.

\section{CHAPTER VI.}

General Sumter receives the thanks of Congress for his services-What Cornwallis said of him-Sumter again takes the field-Destroys the magazines of Fort Granby-Retreats-Captures an escort with wagons and stores-Advances to Fort Watson-Retires on the approach of Lord Rawdon-Defeats Major Fraser-Raises three regiments of regulars-Services of that force-Sumter in the State Convention-In Congross-His retirement from public life-His death... 350 


\section{I F E O F}

\section{MAJOR GENERAL HENRY LEE.}

\section{CHAPTER I.}

Birth of Henry Lee-Private instruction at home- oes to Princeton College-Is graduated-Takes charge of his father's private business during his absence on public affairs-His remarkable abilities-Takes an interest in military affairs-Appointed Captain in Bland's regiment of cavalry - Great want of cavalry in the army under Washington-Bland's regiment joins the main armyEngaged in the Battle of Brandywine-Washington's retreat after the battle-Lee sent on detached service with Colonel Alexander Hamilton-Singular adventures of the two officers-Their life-long friendship.

Henry LeE was born at the family seat of the Lees, at Stratford, Westmoreland county, Virginia, January 29th, 1752. His family was highly distinguished for respectability and talent. He received the rudiments of his education from a private tutor, a common practice among wealthy families in the South. When thoroughly fitted for admission, he was sent to Princeton College, New Jersey, then under the presidency of the patriotic Dr. 
Witherspoon, where he was graduated in the eighteenth year of his age. In addition to the usual course of study, Lee, young as he was, appears to have paid particular attention to the Belles Lettres; and to have practiced the writing of English composition with success; a fair augury of his rather remarkable career in the republic of letters, as well as the camp and the council chamber.

In the year 1774 , soon after his return home from college, young Lee was intrusted with the management of all the private business concerns of his father, whilst the latter was engaged in negotiating a treaty with some Indian tribes on behalf of the colony of Virginia. In the discharge of this complicated and laborious duty, Henry Lee displayed a degree of prudence, industry, and ability', far beyond his years.

The two years succeeding, viz: 1775,1776 , formed a period of intense excitement in Virginia, that colony having assumed a leading position in resisting by force of arms the oppression of the mother country, Henry Lee was among the foremost to take an active part in organizing and disciplining the militia; and the study of the art of war became now the main business of his life.

In consequence of the active part which he took in military affairs, Henry Lee, in 1776, was appointed captain in one of the twenty-six companies of cavalry, raised in Virginia, to remedy a very important deficiency in the Revolutionary army. These troops were destined to become the celebrated "Virginia Horse," so lauded by Mr. Cooper in his novel of The Spy; and no part of the force was to become so famous as that which 
now and shortly afterwards was placed under the command of Henry Lee.

The reader will not fail to remember that about this time Great Britain was pouring large, and well appointed armies upon our shores. General Howe, the commander-in-chief, having under his command in the neighborhood of New York not less than thirty thousand men, while Washington could not muster a sixth part of this number.

The different colonies were duly impressed by the representations of Congress and of General Washington, with the indispensable importance of sending to the aid of the American commander-in-chief every possible reinforcement. In pursuance of this design, the twenty-six companies of cavalry were incorporated into one regiment, under the command of Lieutenant Colonel Theodorick Bland, and offered by the State of Virginia to Congress.

No offer could possibly have been more acceptable to Washington at that time, (1777.) During the campaign of the preceding year, the army under his command had suffered severely from the total want of efficient cavalry, and many of the disasters of that trying period of the war were attributable to this deficiency in the army.

Henry Lee's company formed a portion of the Virginia Horse. Mr. Irving, in his life of Washington, thus notices young Lee's entrance upon his new theatre of action :

At this time Henry Lee of Virginia, of military renown, makes his first appearance. $\mathrm{He}$ was in the twenty-second year of his age, and in the preceding year had commanded a company of Virginia Volunteers. 
He had recently signalized himself in scouting parties, harassing the enemies' pickets. Washington, in a letter to the President of Congress (Aug. 30th), writes: "This minute twenty-four British prisoners arrived, taken yesterday by Captain Lee of the light-horse." His adventurous exploits soon won him notoriety, and the popular appellation of "Light-horse Harry." He was favorably noticed by Washington throughout the war. Perhaps there was something besides his bold, dashing spirit, which won him this favor. There may have been early recollections connected with it. Lee was the son of the lady who first touched Washington's heart in his schoolboy days, the one about whom he wrote rhymes at Mount Vernon and Greenway Court-his "lowland beauty."

In his last statement respecting Henry Lee's mother, Mr. Irving appears to have been mistaken, as a son of Lee has assured the writer of this memoir, that there is not the slightest foundation for this idea of the accomplished biographer of Washington, although he repeatedly returns to it when mentioning Light-horse Harry, for whom he, as well as Washington, had a decided partiality.

The common accounts say that Colonel Bland's regiment joined the army under Washington in Sept. 1777. The following letter from Captain Lee to Colonel Bland shows that the regiment was already with Washington's army in New Jersey in April 1777. It also affords pleasing evidence of the Captain's solicitude for the good appearance of his men. 
Boundbrook, April 13th, 1777.

Dear Colonel,--Your favor by Lieutenant Peyton, I received yesterday, and am much obliged to you for your favorable sentiments of me and mine. I find my station is Chatham; you require that I march through Morristown. How happy would I be, if it was possible for my men to be furnished with caps and boots, prior to my appearance at head-quarters! You know, dear Colonel, that, justly, an offecer's reputation depends not only on the discipline, but appearance of his men. Could the articles mentioned be allowed my troop, their appearance into Morris would secure me from the imputation of carelessness as their captain, and I have vanity to hope would assist in procuring some little credit to the colonel and regiment. Pardon my solicitations on any head, respecting the condition of my troop; my sole object is the credit of the regiment.

Yours affectionately, \&c.

Another letter to Colonel Bland, dated April 25th, explains his detention by General Lincoln at Boundbrook to assist in an attempt against the Hessian picquet.*

A letter from General Washington to Colonel Bland, dated Wilmington, August 30th, 1777, shows that Bland's regiment was with the main army in Delaware, watching the movements of the British army. They had left Philadelphia with Washington and the main army on the 24th of August, and Wilmington was now the general's head-quarters. The enemy had already landed at the head of Elk, and were proceeding towards the Brandy* Bland's Papers, p. 51, 53. 
wine. Distressed by want of horses, hemmed in by strong parties of the American Militia, and almost daily annoyed by the attacks of Captain Henry Lee's and other smaller detachments of cavalry upon his pickets, Howe did not move forward till the third of September.

A letter from Colonel Bland to General Washington, without date, but written evidently a few days before the battle of Brandywine, communicates information respecting the enemy's movements. On the day of the battle, before its commencement, Colonel Bland was employed in reconnoitering the enemy with his horse. At halfpast one he writes to Sullivan and to Washington that he had discovered the position of a portion of the enemy's force, and at two o'clock General Sullivan writes to Washington: "Colonel Bland has this moment sent me word, that the enemy are in the rear of my right, about two miles, coming down. There are, he says, about two brigades of them. He also says he saw a dust back in the country for above an hour.".

From these notices it is apparent that Bland's regiment was actively engaged in the battle of Brandywine which was fought on the 11th of September, and in which, notwithstanding it has always been considered a perfect defeat of the Americans, they nevertheless put hors de combat not less than one fifth of the British troops, ${ }^{*}$ and taught General Howe to respect the valor of American troops to that extent that he never afterwards ventured to encounter Washington in a pitched battle.

Of Captain Lee's behavior in the battle of Brandywine, we find no written record; but he has given us in * See Headley's Life of Washington. 
his "Memoirs of the War in the Southern Department of the United States," " $\Omega$ interesting relation of certain events immediately following the battle, in which he took an active part. It is as follows :

- Washington retired during the night to Chester;* whence he decamped the next morning. Taking the route to Philadelphia, and crossing the Schuylkill, he moved up that river, until he reached Swedesford, where he recrossed it, and gained the Lancaster road. On the 15th of September he advanced to meet the enemy, who, after three days' repose on the field of battle, quitted the Brandywine, pointing his march to the upper fords of the Schuylkill. A violent storm, accompanied by a deluge of rain, stopped the renewal of battle on the following day, near the Warren tavern on the road from Philadelphia to Lancaster; for which the two armies were arrayed, and in which the van troops were engaged. Separated by the tempest, the American general exerted himself to replenish his ammunition, destroyed by the fall of water, from the insecurity of our $\dagger$ cartouch boxes

* It is worthy of remark that Howe was but eighteen miles from Pliladelphia, and Washington, who reached Chester on the night of the battle, was sixteen miles distant, the Delaware on his right, the Schuylkill in his front, and his enemy on his left. Was it not surprising that the British general did not perceive and seize the advantage, so plainly before him, by a forced march as soon as his troops had snatched food and rest?

† Among the many and afflicting disadvantages imposed on the American general, the insufficiency of the implements covering our powder, was not the least. There existed another ground of disparity, which continued nearly to the end of the war-inferiority of arms. Some of our musketry were without bayonets; and not a single bri- 
and artillery tumbrels; while the British general pursued his route across the Schuylkill, directing his course to the American metropolis. Contiguous to the enemy's route, lay some mills stored with flour, for the use of the American army. Their destruction was deemed necessary by the commander in chief; and his aide-de-camp, Lieutenant Colonel Hamilton, * attended by Captain Lee, $\dagger$ with a small party of his troop of horse, were dispatched in front of the enemy, with the order of execution. The mill, or mills, stood on the bank of the Schuylkill. Approaching, you descend a long hill leading to a bridge over the mill-race. On the summit of this hill two videts were posted; and soon after the party reached the mills, Lieutenant Colonel Hamilton took possession of a flat-bottomed boat for the purpose of transporting himself and his comrades across the river, should the sudden approach of the enemy render such retreat necessary. In a little time this precaution manifested his sagacity: the fire of the videts announced the enemy's appearance. The dragoons were ordered instantly to embark. Of the small party, four with the lieutenant colonel jumped into the boat, the van of the

gade had muskets of the same caliber; by which means, a corps expending its ammunition, could not use that of an adjoining corps. The latter deficiency is imputable to our porerty, as arms in that stage of the war could only be procured by purchase from abroad; but the former is justly to be ascribed to the criminal supineness of our contractors, as we abounded in good leather and good workmen.

* The celebrated Alexander Hamilton.

$\dagger$ Henry Lee, afterwards Lieutenant Colonel Lee of the legion cavalry, the subject of the present memoir. 
enemy's horse in full view, pressing down the hill in pursuit of the two videts. Captain Lee, with the remaining two, took the decision to regain the bridge, rather than detain the boat.

Hamilton was committed to the flood, struggling against a violent current, increased by the recent rains; while Lee put his safety on the speed and soundness of his horse.

The attention of the enemy being engaged by Lee's push for the bridge, delayed the attack upon the boat for a few minutes, and thus afforded to Hamilton a better chance of escape. The two videts preceded Lee as he reached the bridge; and himself with the four dragoons safely passed it, although the enemy's front section emptied their carbines and pistols* at the distance of ten or twelve paces. Lee's apprehension for the safety of Hamilton continued to increase, as he heard volleys of carbines discharged upon the boat, which were returned by guns singly and occasionally. He trembled for the probable issue; and as soon as the pursuit ended, which did not long continue, he despatched a dragoon to the commander in chief, describing with feelings of anxiety what had passed, and his sad presage. His letter was scarcely perused by Washington, before Hamilton himself appeared; and, igno-

* The fire of cavalry is at best innocent, especially in quick mo tion, as was then the case. 'The strength and activity of the horse, the precision and celerity of evolution, the adroitness of the rider, boot-top to boot-top, and the keen edge of the sabre, with fitness of ground, and skill in the leader, constitute their vast power, so often decisive in the day of battle. 
rant of the contents of the paper in the general's hand, renewed his attention to the ill-boding separation, with the probability that his friend Lee had been cut off; inasmuch as instantly after he turned for the bridge, the British horse reached the mill, and commenced their operations upon the boat.

Washington with joy relieved his fears, by giving to his aid-de-camp the captain's letter.

Thus did fortune smile upon these two young soldiers, already united in friendship, which ceased only with life. Lieutenant Colonel Hamilton escaped unhurt; but two of his four dragoons, with one of the boatmen, were wounded. 


\section{CHAPTER II。}

Position of Lee favorable to advancement-His attention to discipline - His conduct noticed by Washington-Events after the battle of Brandywine--Lee commands Washington's body guard at the battle of Germantown--Situation of the American army at Valley Forge -Of the British army in Philadelphia_Lee employed in larassing the British lines and cutting off foraging and marauding partiesAttempt to surprise him--Admirable defence-Promoted to be Major and to command an independent partisan corps-Correspondence with Washington.

Young Harry Lee's position in the army was favorable to his acquiring distinction, by great ability and prudence combined with spirit and enterprise; but all these qualities were essential to success, and fortunately he possessed them in an eminent degree.

In order to increase the efficiency of his company, he maintained a very strict discipline, was always attentive to the comfort and well being of his men, and what was of equal importance, he exacted from them the utmost care of their horses and accoutrements. The last was not so very difficult, as all the world knows that a Virginian naturally and instinctively loves a horse, and cherishes him as the apple of his eye; takes pride in his beauty and his speed, and does his utmost to increaso 
his efficiency. Under these circumstances, perhaps, it is not to be wondered at that Lee's company speedily became noted for its achievements, and that its commander was often charged with services in which it was required for the company to move with celerity, and strike the enemy by surprise with certainty and success.

After the battle of Brandywine, which is but a day's march from Philadelphia, it was naturally to be expected that General Howe would instantly take possession of Philadelphia, then the metropolis of the United States. But Washington by his able strategy kept him at bay for two weeks, and it was not till the 26th of September that Howe took Philadelphia, or rather, as Dr. Franklin shrewdly remarked when he heard the news at Paris, "Philadelphia took General Howe."

Captain Lee's activity and prudence, during this period, attracted the particular attention of General Washington. At the battle of Germantown he ordered Captain Lee, with his company, to act as his body guard, a distinction of no ordinary kind, when we consider the remarkable sagacity of Washington in the choice of persons to whom he entrusted any duty of an important and confidential nature.

The winter which followed the battle of Germantown, was passed by General Howe and his army in inactivity and dissipation in Philadelphia, and by Washington and his patriot army in suffering and want at the dreary camp of Valley Forge.

Stedman, a British historian, who was in Howe's army 
at this time, thus describes the condition of Washington and his army as well as that of Howe:

"The American general determined to remain during the winter in the position which he then occupied at Valley Forge, recommending to his troops to build huts in the woods for sheltering themselves from the inclemency of the weather. And it is perhaps one of the most striking traits in General Washington's character, that he possessed the faculty of gaining such an ascendancy over his raw and undisciplined followers, most of whom were destitute of proper winter clothing, and otherwise unprovided with necessaries, as to be able to prevail upon so many of them to remain with him during the winter, in so distressing a situation. With immense labor he raised wooden huts, covered with straw and earth, which formed very uncomfortable quarters. On the east and south, an intrenchment was made-the ditch six feet wide and three in depth; the mound not four feet high, very narrow, and such as might easily have been beat down by cannon. Two redoubts were also begun, but never completed. The Schuylkill was on his left, with a bridge across. His rear was mostly covered by an impassable precipice formed by Valley Creek, having only a narrow passage near the Schuylkill. On the right his camp was accessible with some difficulty, but the approach on his front was on ground nearly on a level with his camp. It is indeed difficult to give an adequate description of his misery in this situation. His army was destitute of almost every necessary of clothing, nay, almost naked; and very often on short allowance of provisions; an extreme mortality 
raged in his hospitals, nor had he any of the most proper medicines to relieve the sick. There were perpetual desertions of parties from him of ten to fifty at a time. In three months he had not four thousand men, and these could by no means be termed effective. Not less than five hundred horses perished from want and the severity of the season. He had often not three days' provision in his camp, and at times not enough for one day. In this infirm and dangerous state he continued from December to May, during all which time every person expected that General Howe would have stormed or besieged his camp, the situation of which equally invited either attempt. To have posted two thousand men on a commanding ground near the bridge, on the north side of the Schuylkill, would have rendered his escape on the left impossible; two thousand men placed on a like ground opposite the narrow pass, would have as effectually prevented a retreat by his rear, and five or six thousand men stationed on the front and right of his camp, would have deprived him of flight on those sides. The positions were such, that if any of the corps were attacked, they could have been instantly supported. Under such propitious circumstances, what mortal could doubt of success? But the British army, neglecting all these opportunities, was suffered to continue at Philadelphia, where the whole winter was spent in dissipation. A want of discipline and proper subordination pervaded the whole army; and if disease and sickness thinned the American army at Valley Forge, indolence and luxury perhaps did no less injury to the British troops at Philadelphia. During the winter a very unfortunate inatten- 
tion was shown to the feelings of the inhabitants of Philadelphia, whose satisfaction should have been vigilantly consulted, both from gratitude and from interest. They experienced many of the horrors of civil war. The soldiers insulted and plundered them, and their houses were occupied as barracks, without any compensation being made to them. Some of the first families were compelled to receive into their habitations individual officers, who were even indecent enough to introduce their mistresses into the mansions of their hospitable entertainers. This soured the minds of the inhabitants, many of whom were Quakers.

"But the residence of the army at Philadelphia occasioned distresses which will probably be considered by the generality of mankind as of a more grievous nature. It was with difficulty that fuel could be got on any terms. Provisions were most exorbitantly high. Gaming of every species was permitted, and even sanctioned. This vice not only debauched the mind, but, by sedentary confinement, and the want of seasonable repose, enervated the body. A foreign officer held the bank at the game of faro, by which he made a very considerable fortune; and but too many respectable families in Britain had to lament its baleful effects. Officers who might have rendered honorable service to their country, were compelled, by what was termed a bad run of luck, to dispose of their commissions, and return penniless to their friends in Europe. The father who thought he had made a provision for his son by purchasing him a commission in the army, ultimately found that he had put his son to school to learn the science of gambling, 
not the art of war. Dissipation had spread through the army, and indolence and want of subordination; its natural concomitants. For, if the offeer be not vigilant, the soldier will never be alert.

"Sir William Howe, from the manners and religious opinions of the Philadelphians, should have been particularly cautious. For this public dissoluteness of the troops could not but be regarded by such people as a contempt of them, as well as an offence against piety; and it influenced all the representations which they made to their countrymen respecting the British. They inferred from it also, that the commander could not be sufficiently intent on the plans of either conciliation or subjugation; so that the opinions of the Philadelphians, whether erroneous or not, materially promoted the cause of Congress. During the whole of this long winter of riot and dissipation, General Washington was suffered to continue, with the remains of his army, not exceeding five thousand effective men at most, undisturbed at Valley Forge: considerable arrears of pay due to them; almost in a state of nature for want of clothing; the Europeans in the Amęrican service disgusted, and deserting in great numbers, and indeed in companies, to the British army, and the natives tired of the war. Yet, under all these favorable circumstances for the British interest, no one step was taken to dislodge Washington, whose cannon were frozen up and could not be moved. If Sir William Howe had marched out in the night, he might have brought Washington to action; or, if he had retreated, he must have left his sick, cannon, ammunition, and heavy baggage behind. A noc- 
turnal attack on the Americans would have had this further good effect: it would have depressed the spirit of revolt, confirmed the wavering, and attached them to the British interest. It would have opened a passage for supplies to the city, which was in great want of provisions for the inhabitants. It would have shaken off that lethargy in which the British soldiers had been immerged during the winter. It would have convinced the wellaffected that the British leader was in earnest. If Washington had retreated, the British could have followed. With one of the best appointed, in every respect, and finest armies (consisting of at least fourteen thousand effective men) ever assembled in any country, a number of officers of approved service, wishing only to be led to action, this dilatory commander, Sir William Howe, dragged out the winter without doing any one thing to obtain the end for which he was commissioned. Proclamation was issued after proclamation, calling upon the people of America to repair to the British standard, promising them remission of their political sins, and an assurance of protection in both person and property; but these promises were confined merely to paper. The best personal security to the inhabitants was an attack by the army, and the best security of property was peace; and this to be purchased by successful war. For, had Sir William Howe led on his troops to action, victory was in his power, and conquest in his train. During Sir William Howe's stay at Philadelphia, a number of disaffected citizens were suffered to remain in the garrison; these people were ever upon the watch, and 
communicated to Washington every intelligence he could wish for."

We have copied this passage from Stedman with a view to show the contrast between the situation of Washington and Howe, and their respective armies, as exhibited by an enemy to our cause. It is literally the contrast between virtue and vice. The final result shows that Providence, in permitting the occupation of Philadelphia by the British army, was really promoting the cause of human liberty.

Fortunately for America, says Marshall, there were features in the character of Washington which, notwithstanding the discordant materials of which his army was composed, attached his officers and soldiers so strongly to his person, that no distress could weaken their affection, nor impair the respect and veneration in which they held him. To this sentiment is to be attributed, in a great measure, the preservation of a respectable military force, under circumstances but too well calculated for its dissolution.

Through this severe experiment on their fortitude, the native Americans persevered steadily in the performance of their duty; but the conduct of the Europeans, who constituted a large part of the army, was, to a considerable extent, less laudable; and at no period of the war was desertion so frequent as during this winter. Aided by the disaffected, deserters eluded the vigilance of the parties who watched the roads, and great numbers escaped into Philadelphia with their arms.

In a few days, the army was rescued from the famine with which it had been threatened, and considerable sup- 
plies of provisions were laid up in camp. It was perceived that the difficulties which had produced such melancholy effects, were created more by the want of due exertion in the commissary department, and by the efforts of the people to save their stock for a better market, than by any real deficiency of food in the country.

This severe demonstration seems to have convinced Congress that their favorite system was radically vicious, and the subject was taken up with the serious intention of remodeling the commissary department on principles recommended by experience. But such were the delays inherent in the organization of that body, that the new system was not adopted until late in April.

At no period of the war had the situation of the American army been more perilous than at Valley Forge. Even when the troops were not entirely destitute of food, their stock of provisions was so scanty that a quantity sufficient for one week was seldom in store. Consequently, had General Howe moved out in force, the American army could not have remained in camp; and their want of clothes disabled them from keeping the field in the winter. The returns of the first of February exhibit the astonishing number of three thousand nine hundred and eighty-nine men in camp, unfit for duty for want of clothes. Scarcely one man of these had a pair of shoes. Even among those returned capable of doing duty, many were so badly clad, that exposure to the cold of the season must have destroyed them. Although the total of the army exceeded seventeen thousand men, the present effective rank and file amounted to only five thousand and twelve. 
While the sufferings of the soldiers filled the hospitals, a dreadful mortality continued to prevail in those miserable receptacles of the sick. A violent putrid fever swept off much greater numbers than all the diseases of the camp.

If then during the deep snow which covered the earth for a great part of the winter, the British general had taken the field, his own army would indeed have suffered greatly, but the American loss is not to be calculated.

Happily, the real condition of Washington was not well understood by Sir William Howe; and the characteristic attention of that officer to the lives and comfort of his troops, saved the American army. Fortunately, he confined his operations to those small excursions that were calculated to enlarge the comforts of his own soldiers, who, notwithstanding the favorable dispositions of the neighboring country, were much distressed for fuel, and often in great want of forage and fresh provisions. The vigilance of the parties on the lines, especially on the south side of the Schuylkill, intercepted a large portion of the supplies intended for the Philadelphia market; and corporal punishment was frequently inflicted on those who were detected in attempting this infraction of the laws. As Captain Lee was particularly active, a plan was formed, late in January, to surprise and capture him in his quarters. An extensive circuit was made by a large body of cavalry, who seized four of his patrols without communicating an alarm. About break of day the British horse appeared; upon which Captain Lee placed his troopers that were in the house, at the doors and windows, who behaved so gallantly as to re- 



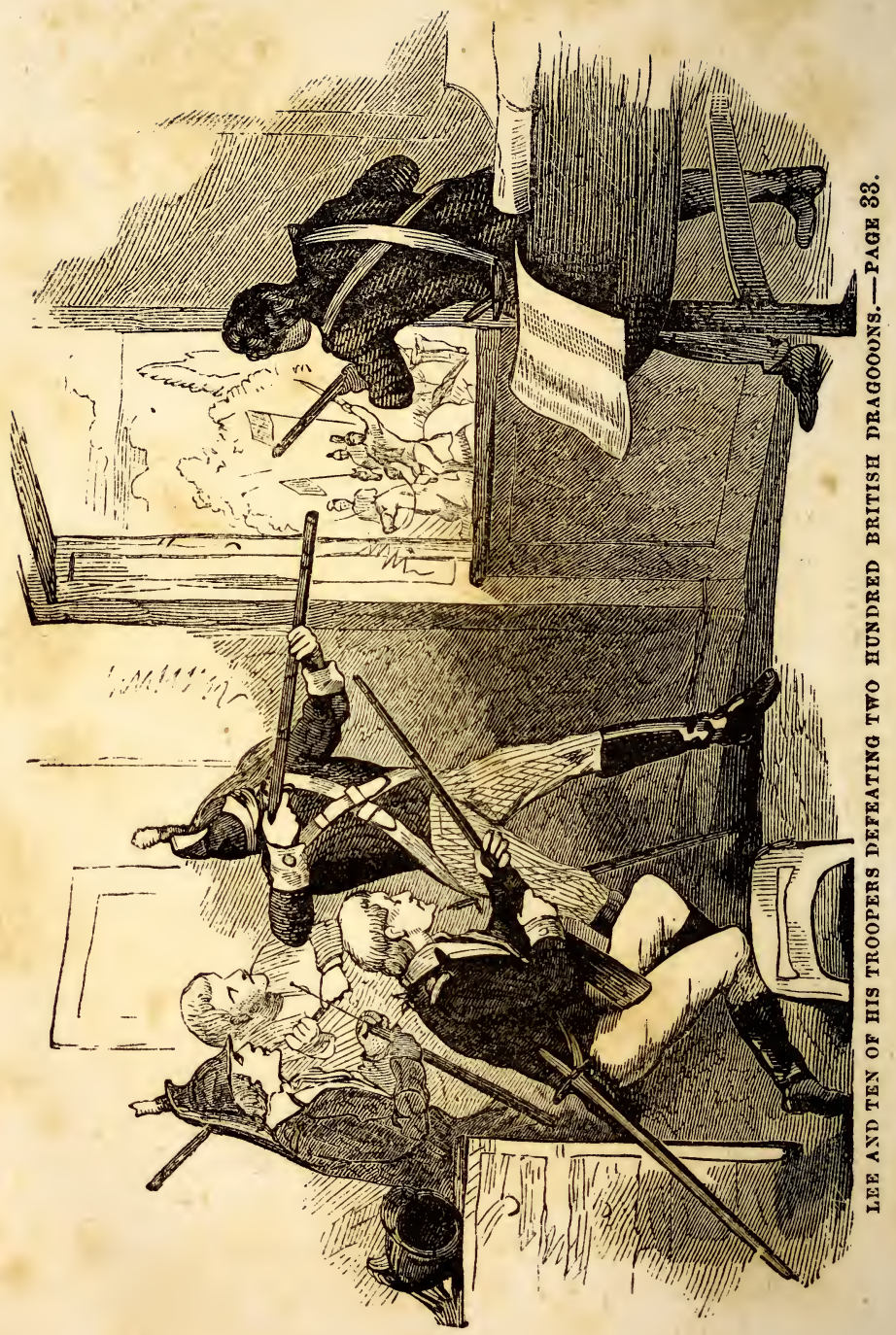


pulse the assailants without losing a horse or man. Only Lieutenant Lindsay and one private were wounded. The whole number in the house did not exceed ten.* That of the assailants was said to amount to two hundred. They lost a sergeant and three men, with several horses, killed; and an officer and three men wounded.

The following is Captain Lee's report of this affair to General Washington: "I am to inform your Excellency of an action, which happened this morning, between a party of the enemy's dragoons and my troop of horse. They were near two hundred in number, and by a very circuitous route endeavored to surprise me in quarters. About daybreak they appeared. We were immediately alarmed, and manned the doors and windows. The contest was very warm; the British dragoons trusting to their vast superiority in number, attempted to force their way into the house. In this they were baffled by the bravery of my men. After having left two killed and four wounded, they desisted and sheered off. We are trying to intercept them. Colonel Stevens has pushed a party of infantry to reach their rear. So well directed was the opposition, that we drove them from the stables and saved every horse. We have got the arms, some cloaks, \&c. of their wounded. The only damage I at present know of, is a slight wound received by Lieutenant Lindsay. I am apprehensive about the patrols. The enterprise was certainly daring, though the issue of it very ignominious. I had not a soldier for each window."January $20 t h$.

* Major Jameson was accidentally present, and engaged in this skirmish. 
Again; "We have at length ascertained the real loss of this day. Four privates, belonging to the patrol at the square, were taken. I am told they made a brave resistance. The quartermaster-sergeant, who imprudently ran from our quarters prior to the commencement - of the skirmish, was also taken. The loss sustained stands thus: one sergeant and four privates taken; one lieutenant and two privates wounded. By what I can learn from the people of Derby, the enemy's loss is as follows: three privates dead; one commissioned officer, one sergeant, and three privates wounded."

The following letter of General Washington to Captain Lee attests his sense of the merit of his young protegé :

"Mr Dear LEE,-Although I have given you my thanks in the general orders of this day, for the late instance of your gallant behavior, I cannot resist the inclination I feel to repeat them again in this manner. I needed no fresh proofs of your merit, to bear you in remembrance. I waited only for the proper time and season to show it; those, I hope, are not far off. I shall also think of and will reward the merit of Lindsay, when an opening presents, as far as I can consistently; and I shall not forget the corporal, whom you have recommended to my notice. Offer my sincere thanks to the whole of your gallant party, and assure them, that no one felt pleasure more sensibly, or rejoiced more sincerely for your and their escape, than your affectionate, \&c."

Washington soon afterwards so strongly recommended Captain Lee to Congress, that he was appointed to the 
command of two troops of horse with the rank of major. This body of troops was to act as an independent partisan corps.

The following is Washington's letter to the President of Congress, soliciting Lee's promotion:

"Captain Lee of the light dragoons, and the officers under his command, having uniformly distinguished themselves by a conduct of exemplary zeal, prudence, and bravery, I took occasion, on a late signal instance of it, to express the high sense I entertained of their merit, and to assure him, that it should not fail of being properly noticed. I was induced to give this assurance from a conviction, that it is the wish of Congress to give every encouragement to merit, and that they would cheerfully embrace so favorable an opportunity of manifesting this disposition. I had it in contemplation at the time, in case no other method more eligible could be adopted, to make him an offer of a place in my family. I have consulted the committee of Congress upon the subject, and we were mutually of opinion, that giving Captain Lee the command of two troops of horse on the proposed establishment, with the rank of major, to act as an independent partisan corps, would be a mode of rewarding him very advantageous to the service. Captain Lee's genius particularly adapts him to a command of this nature; and it will be the most agreeable to him of any station in which he could be placed.

"I beg leave to recommend this measure to Congress, and shall be obliged by their decision as speedily as may be convenient. The campaign is fast approaching, and 
there will probably be very little time to raise and prepare the corps for it. It is a part of the plan to give Mr. Lindsay the command of the second troop, and to make Mir. Peyton captain-lieutenant of the first."

In May, 1778, Major Lee's partisan corps of light dragoons was increased from two companies to three, and the appointment of the additional officers was referred by Congress to General Washington. 


\section{CHAPTER III.}

Separation of Lee's corps from Bland's regiment-Lee's attack or, and dispersion of a detachment of Donop's Hessian yagers-Confdence reposed in Major Lee by Washington-Attack on and surprise of Paulus Hook by a detachment under Lee's commandWashington's praise of Lee-Thanks of Congress and a gold medal voted to Lee-Promotion of his officers, and pecuniary rewards to his men-liee sent on a confidential mission to Count D'Estaing by Washington.

After the formation of Major Lee's command into a separate partisan corps, it was, of course, detached from the regiment of Colonel Theodorick Bland, who was subsequently employed in guarding the Convention prisoners taken at Saratoga and sent to Virginia, while Lee's Legion was engaged in most active service throughout the whole war.

In September, 1777, when the main army under Washington was encamped at White Plains, a detachment from the British lines at Kingsbridge, made a foray in the intervening district, plundering the inhabitants, without distinction, of provisions and forage, and even of the very clothes on their backs. Of these ruffians, a party composed of one hundred of Captain Donop's Hessian yagers, pursuing their depredations between Tarrytown and Dobbs's Ferry, fell in with a detachment of infantry 
under Colonel Richard Butler, and of cavalry under Major Henry Lee, by whom they were completely surprised. Ten of them were killed on the spot, a lieutenant and eighteen privates were made prisoners, and the whole would have been captured or killed if the roughness of the country had not impeded the operations of Lee and his troopers, and enabled the yagers to escape by scrambling up hill-sides or plunging into ravines.*

Of the confidential nature of the services committed by Washington to Major Lee, we may form some estimate by the following letter, from the commander-inchief to the partisan officer, at the time when the celebrated storming of West Point was meditated :

"I have received your letter, dated yesterday, and thank you for the information it contained. I have now to request, that you will endeavor to employ some person in whom you can confide, and who at the same time is intelligent, to go into the works at Stony Point, or, if admittance is not to be gained, to obtain the best knowledge of them he can, so as to describe the particular kind of works, the precise spots on which they stand, and the strength of the garrison. If you should succeed in this point, I must beg you will transmit to me, without delay, a sketch of the works, that I may be able to form an accurate idea of them. You will yourself take the best view you can, that you may the better know whether the report you get from the person sent in is to be relied on. Describe the number of armed vessels and their situation, and keep the contents of this letter to yourself."

* Irving's Life of Washington. 
Writing to General Wayne, July 14th, 1779, the day before the storming of Stony Point, Washington says, "As it is important to have every information we can procure, if you could manage in the meantime to see Major Lee, it may be useful."

The brilliant success of General Wayne at Stony Point fired the ambition of Lee to undertake some grand exploit of the same description; and as his ordinary duty was to observe the position and movements of the enemy, and detect the most assailable points of attack, he was not long in discovering one entirely suited to his purpose. This was the post at Paulus Hook, opposite New York.

The inception and execution of this brilliant affair is thus described by Judge Marshall.*

While Sir Henry Clinton continued encamped just above Haerlem, with his upper posts at Kingsbridge, and the American army preserved its station in the Highlands, a bold plan was formed for surprising a British post at Paulus Hook, which was executed with great address by Major Lee.

This officer was employed on the west side of the river with directions to observe the situation of the British in Stony Point, but, principally, to watch the motions of their main army. While his parties scoured the country, he obtained intelligence which suggested the idea of surprising and carrying off the garrison at Paulus Hook, a point of land on the west side of the Hudson, immedi-

* Life of Washington, Vol. I, p. 314. Marshall, at that time an officer in the army, states that he was in the detachment of Lord Stirling sent to cover Lee's retreat. 
ately opposite the town of New York, penetrating deep into the river. On the point nearest New York, some works had been constructed, which were garrisoned by four or five hundred men.

A deep ditch, into which the water of the river flowed, having over it a drawbridge connected with a barred gate, had been cut across the isthmus, so as to make the Hook, in reality, an island. This ditch could be passed only at low water. Thirty paces within it was a row of abattis running into the river; and some distance in front of it, was a creek fordable only in two places.

This difficulty of access, added to the remoteness of the nearest corps of the American army, impressed the garrison with the opinion that they were perfectly secure; and this opinion produced an unmilitary remissness in the commanding officer, which did not escape the vigilance of Lee.

On receiving his communications, General Washington was inclined to favor the enterprise they suggested; but withheld his full assent, until he was satisfied that the assailants would be able to make good their retreat.

The Hackensack, which communicates with the waters of the Hudson below New York, runs almost parallel with that river quite to its source, and is separated from it only a few miles. This neck is still farther narrowed by a deep creek which divides it, and empties into the Hackensack below Fort Lee. West of that river runs the Passaick, which unites with it near Newark, and forms another long and narrow neck of land. From Paulus Hook to the new bridge, the first place where the Hackensack could be crossed without boats, the distance 
is fourteen miles; and from the North river to the road leading from the one place to the other, there are three points of interception, the nearest of which is less than two miles, and the farthest not more than three. The British were encamped in full force along the North river, opposite to these points of interception. To diminish the danger of the retreat, it was intended to occupy the roads leading through the mountains of the Hudson to the Hackensack with a select body of troops.

Every preparatory arrangement being made, the night of the eighteenth of August was fixed on for the enterprise. A detachment from the division of Lord Stirling, including three hundred men designed for the expedition, was ordered down as a foraging party. As there was nothing unusual in this movement, it excited no suspicion. Lord Stirling followed with five hundred men, and encamped at the new bridge.

Major Lee, at the head of three hundred men, took the road through the mountains which ran parallel to the North river; and, having secured all the passes into York Island, reached the creek which surrounds the Hook between two and three in the morning. He passed first the creek, and then the ditch undiscovered; and, about three in the morning, entered the main work, and with the loss of only two killed and three wounded, made one hundred and fifty-nine prisoners, including three officers. Very few of the British were killed. Major Sutherland, who commanded the garrison, threw himself with forty or fifty Hessians into a strong redoubt, which it was thought inadvisable to attack, because the time occupied in carrying it might endanger the retreat. Wast- 
ing no time in destroying what could easily be replaced, Major Lee hastened to bring off his prisoners and his detachment.

To avoid the danger of retreating up the narrow neck of land which has already been described, some boats had been brought in the course of the night to Dow's Ferry on the Hackensack, not far from Paulus Hook. The officer who guarded them was directed to remain until the arrival of the troops engaged in the expedition, which, it was understood, would happen before day. The light having made its appearance without any intelligence from Major Lee, the officer having charge of the boats conjectured that the attack had been postponed; and, to avoid discovery, retired with them to Newark. The head of the retreating column soon afterwards reached the ferry; and, fatigued as they were by the toilsome march of the preceding night, were compelled to pass as rapidly as possible up the narrow neck of land between the two rivers to the new bridge. A horseman was dispatched with this information to Lord Stirling, and the line of march was resumed.

About nine in the preceding evening, Major Buskirk had been detached up the North river with a considerable part of the garrison of Paulus Hook, and some other troops, for the purpose of falling in with the American party supposed to be foraging about the English neighborhood.

On receiving intelligence of the disappointment respecting the boats, Lord Stirling took the precaution to detach Colonel Ball with two hundred fresh men to meet Lee, and cover his retreat. Just after Ball had passed, 
Buskirk entered the main road, and fired on his rear. Taking it for granted that this was only the advanced corps of a large detachment sent to intercept the party retreating from Paulus Hook, Ball made a circuit to avoid the enemy; and Buskirk, finding a detachment he had not expected, took the same measure to secure his own retreat. The two parties, narrowly missing each other, returned to their respective points of departure; and Lee reached the new bridge without interruption.*

This critical enterprise reflected much honor on Major Lee with whom it originated, and by whom it was conducted. General Washington announced it to the army in his orders with much approbation; and Congress bestowed upon it a degree of applause more adapted, says Marshall, to the talent displayed in performing the service than to its magnitude.

In his letter to the President of Congress, (May 23d, 1779,) inclosing Lee's report of the capture, Washington says, "The Major displayed a remarkable degree of prudence, address, enterprist, and bravery on this occasion, which does the highest honor to himself and to all the officers and men under his command."

Congress passed resolves highly complimentary to Major Lee, thanking him for " the remarkable prudence, address, and bravery, displayed by him in the attack on the enemy's fort and works at Paulus Hook." Much praise was also bestowed on the officers and soldiers composing his party. A medal of gold, emblematical of the affair, was ordered to be struck and presented to

* The author states these facts from his own observation, and con. versation with other officers of the detachment. 
Major Lee. The brevet rank and pay of captain were given to Lieutenants McAlister and Rudulph, respectively; and fifteen thousand dollars in money were to be distributed among the non-commissioned officers and privates, in such a manner as the commander-in-chief should direct.*

Washington writing to Lee, Oct. 7,1779 , says, "I have given a warrant to Captain Rudulph for the sum granted by Congress to the non-commissioned officers and privates concerned in the attack on Paulus Hook. You will be pleased to distribute this money in proportion to the pay of the non-commissioned officers and privates, which was the manner observed in the case of Stony Point. You may in future, or while on your present command, mark your letters private."

The confidential service on which Lee was employed at the time this letter was written, we learn from Washington's letter to the President of Congress, of Oct. 4th, 1779, in which, speaking of the expected arrival of the Count D'Estaing on the coast, with the French fleet, he says, "But as there is a possibility that he may, on being made acquainted with the numbers and situation of the enemy, prefer an attack on Rhode Island, I have desired General Gates to be looking towards, and preparing for such an event. I had upon the first report of the Count's standing towards this coast, stationed Major Lee at Monmouth, with a letter for the Count, to be carried on board on his first appearance, in which I informed him of the enemy's force by sea and land, and their position at that time, and pointed * Sparkes' Writings of Washington. Vol. 6, p. 376-Note. 
out to him the measures which I thought would be advantageous for him to pursue on his arrival."

It is evident that Lee was chosen for this confidential mission, not only on account of his superior prudence and address, so necessary to insure the safe delivery of the letter, but on account of the intelligence and promptness required to answer all inquiries which the Count might wish to make of Washington's chosen messenger, (an officer of rank, with respect to the state of the country and the war. It was a highly honorable, as well as a confidential mission. 


\section{CHA P T E R IV.}

Lee's Legion placed by Washington under marching order for the South-Sets out-Stopped and ordered back to New Jersey by Washington-Arrives and ordered to take post in rear of the army -Knyphausen's marauding inroad into Jersey-Lee's active and useful services in the battle of Springfield described by General Greene-Lee again ordered on important and confidentiąl service by Washington-To take the command at Monmouth, to await the arrival of the French fleet.

EARLy in the year 1780 it appears to have been the determination of Washington to detach the corps under the command of Major Lee from the main army for service at the south. The corps which already consisted of three companies of cavalry had been further augmented by the addition of a body of infantry, and in order that it might be designated by a term which should be applicable to both kinds of the force it comprised, and at the same time include the name of its commander, it was thenceforth known in the army as LeE's LeGIoN, a name under which it acquired imperishable fame.

On March 30th, 1780, in a letter from Washington at his headquarters, Morristown, to Major Lee, he says, "You will be pleased upon receipt of this, to take the most expeditious measures for putting the whole force, both horse and foot, in readiness to march. If you move, your destination will be South Carolina. The 
horse will go the whole way by land; the foot will gn down the Chesapeake Bay by water, and meet the horse at Petersburg. As soon as you have.given the necessary orders at Burlington, you had best repair to Philadelphia, and apply to the Board of War, to whom I have written on the subject, for the articles wanted to equip the corps for so long a march."

Lee set out on his march southward soon after receiving these orders. But the arrival of the Marquis de Lafayette, with the promise of more aid from France, appears to have occasioned a change in Washington's decision, respecting the theatre of operations for Lee's Legion. Writing to Lafayette, from Morristown, May 20th, 1780, Washington says, "I send a letter with this to stop Lee's corps."

Lee was wanted for confidential service near the Commander-in-chief. He does not appear to have reported himself and his corps as ready for service in Washington's neighborhood until June, when he received from him the following letter :

Head-Quarters, near Springfield, 11 June, 1780.

Dear Sir-I have received your favour of this date. The spirit which has been exhibited by your corps gives me pleasure, and, be assured, meets with my thanks and approbation. As your rapid progress must have fatigued the cavalry in some degree, I wish you for the present to take post somewhere in our rear. Perhaps Chatham, or its vicinity, is as well calculated to afford you forage as any other place. You will, however, when you have fixed on the spot, be pleased by a line to 
point it out to me. I shall be glad to see you at my quarters to-morrow morning. I am, \&c.

A few days after Lee's receipt of this, General Knyphausen made his infamous marauding incursion into Jersey, sacking Connecticut Farms, and burning Springfield, without any other apparent motive than that of inflicting distress upon the inhabitants. At Springfield he was met by a detachment under General Greene, and a spirited action ensued, in which Lee's Legion took an active part.

General Greene in his despatch to Washington, 24th June, 1780, giving an account of the battle of Springfield, says :

"The enemy advanced from Elizabethtown about five o'clock in the morning, said to be about five thousand infantry, with a large body of cavalry, and fifteen or twenty pieces of artillery. Their march was rapid and compact. They moved in two columns, one on the main road leading to Springfield, the other on the Vauxhall road. Major Lee, with the horse and pickets, opposed the right column, and Colonel Dayton with his regiment the left, and both gave as much opposition as could have been expected from so small a force. Our troops were so extended, in order to guard the different roads leading to the several passes over the mountains, that I had scarcely time to collect them at Springfield and make the necessary dispositions, before the enemy appeared before the town; when a cannonade commenced between their advance and our artillery posted for the defence of the bridge.

"The enemy continued manœurring in our front for 
upwards of two hours, which induced me to believe they were attempting to gain our flanks. My force was small, and from the direction of the roads my situation was critical. I disposed of the troops in the best manner I could, to guard our flanks, secure a retreat, and oppose the advance of their columns. Colonel Angell, with his regiment, and several small detachments, and one piece of artillery, was posted to secure the bridge in front of the town. Colonel Shreve's regiment was drawn up at the second bridge to cover the retreat of those posted at the first. Major Lee, with his dragoons, and the pickets commanded by Captain Walker, was posted at Little's Bridge, on the Vauxhall road; and Colonel Ogden was detached to support him. The remainder- of General Maxwell's and General Stark's brigades were drawn up on the high grounds at the Mill. The militia were on the flanks. Those under the command of General Dickenson made a spirited attack upon one of the enemy's flanking parties, but his force was too small to push the advantage he had gained.

"While the enemy were making demonstrations to their left, their right column advanced on Major Lee. The bridge was disputed with great obstinacy, and the enemy must have received pretty considerable injury; but, by fording the river and gaining the point of the hill, they obliged the major with his party to give up the pass. At this instant of time their left column began the attack on Colonel Angell. The action was severe and lasted about forty minutes, when superior numbers overcame obstinate bravery, and forced our troops to retire over the second bridge. Here the enemy were warmly 
received by Colonel Shreve's regiment; but, as they advanced in great force, with a large train of artillery, he had orders to join the brigade."

The enemy after these movements set fire to almost every house in Springfield, and then precipitately retreated to Elizabethtown Point, where they remained till midnight, and then began to send their troops across to Staten Island. "By six o'clock this morning," continues Greene, in his despatch, "they had totally evacuated the Point and removed their bridge. Major Lee fell in with their rear guard; but they were so covered by their works, that little or no injury could be done them."

On the 11th of July, 1780, Washington writes to Lee: "You will proceed to Monmouth and establish yourself in that vicinity. When you arrive there, you will see General Forman, who is charged with despatches for a French fleet expected at the Hook, and to keep a look out for its arrival. You will give such assistance as will be necessary. Pilots will be stationed in that quarter, who will put themselves under your protection. Should a fleet appear, which you have good reason to believe is a French fleet, General Forman and you will immediately go on board with the despatches, and offer your service to the general and admiral for everything in which you can be useful to them.

"You will instantly impress every kind of refreshment the country affords, cattle, vegetables, and the like, for the use of our allies; for which purpose you will make previous arrangements, and execute them in the manner most effectual, and least grievous to the inhabitants, 
giving certificates for everything taken. Should there be any State troops or militia in service, not under a superior officer, you will take command of them. If there should be a superior officer, you will endeavor to engage him to coöperate with you. Advise me instantly of anything important that happens on the coast; of all vessels coming in and going out, and of whatever may be doing at the Hook and in the Bay. On the appearance of the fleet, send immediately a dragoon to head-quarters, and another to the minister of France, with advice of the arrival."

It is sufficiently apparent that this was another confidential and highly honorable mission, confided to Major Lee by the commander-in-chief. 


\section{HAPTER V.}

Arnold's treason-Lee's correspondence with Washington on the suspicions against St. Clair and other officers-Lee engages his sergeant major, Champe, to desert, go to the British camp, and seize Arnold and bring him off alive-Lee's own interesting narrative of the whole affair.

When the treason of General Arnold became known to Washington and the army, "rumors went abroad, that other officers of high rank in the American army were implicated with Arnold. It was proved afterwards, that these rumors were set afloat by the enemy, for the purpose of exciting distrust and discord in the American camp. Till this fact was established, however, General Washington felt extreme anxiety, and omitted no effort to ascertain the truth. Secret agents were sent into New York to make inquiries and procure intelligence. The intercourse was managed chiefly by Major Henry Lee, who was stationed with his dragoons on the lines, and whose ability and address, as well as his energy and promptitude, peculiarly qualified him for such a service. A paper had been found, in which the name of General St. Clair was mentioned in a suspicious manner, and which was traced to an emissary by the name of Brown.*" * Sparks' Writings of Washington, Vol. 7. p. 544. 
MAJOR LEE TO GENERAL WASHINGTON.

"October 13th, 1780.- -Sir: I have made it my business to see the person, who was Captain Brown's guide. From a minute examination of him, I am confident that General St. Clair was named to deceive, that Captain Brown did not see or hear from General St. Clair, and that Captain Brown passed himself on his conductor as a person engaged in our service, although his object was to communicate with some gentleman of consequence among us. I am apt to believe that he was charged with despatches for General Arnold.

"I have the honor to be, \&c."

GENERAL WASHINGTON TO MAJOR LEE.

"October 13th.--Dear Sir : I am very glad your letter of this date has given strength to my conviction of the innocence of the gentleman who was the subject of your inquiry. I want to see you on a particular piece of busi- . ness. If the day is fair, and nothing of consequence intervenes, I will be at the Marquis's quarters by ten o'clock to-morrow. If this should not happen, I shall be glad to see you at head-quarters. I am, \&c."

Other papers were sent to General Washington by his spies in New York, which cleared up the matter fully, and rendered it certain, that all the insinuations against the American officers were to be ascribed to the arts of the enemy.

A project was set on foot for seizing the person of Arnold. It was concerning this matter, that Washington wished to see Major Lee. The romantic adventures of Sergeant Champe, so spiritedly and beautifully des- 
cribed in Lee's Memoirs, are well known.* The following letters passed between General Washington and Major Lee on that subject.

MAJOR LEE TO GENERAL WASHINGTON.

"Light Camp, 16 October, 1780.-I waited on Colonel Dey yesterday, but received no information favorable to the business you were pleased to charge me with. On my return last evening the Marquis mentioned to me the same matter as very eligible, and Colonel Hamilton made some inquiry on the same subject. I communicate this to you, lest a mention of it by those gentleman to you may alarm you on the. score of secrecy. Be assured, Sir, I shall endeavour most earnestly to accomplish your wishes, and have hopes to establish the commencement on Wednesday next."

\section{MAJOR LEE TO GENERAL WASHINGTON.}

[October 20th. $\dagger$ - - Sir: I have engaged two persons to undertake the accomplishment of your Excellency's wishes. In my negotiation I have said little or nothing concerning your Excellency, as I presumed it would operate disagreeably, should the issue prove disastrous.

"The chief of the two persons is a sergeant in my cavalry. To him I have promised promotion. The other is an inhabitant of Newark; I have had experience of his fidelity; and his connections with the enemy render

* Memoirs of the War in the Southern Department of the United States, Vol. II. pp. 159-187.

$\dagger$ In the original this letter is not dated ; but in Lee's Memoirs, (Vol. II. p. 182,) it is said to have been written on the same day as Washington's answer to it. 
him, with his personal qualifications, very fit for the business. To this man I have engaged one hundred guineas, five hundred acres of land, and three negroes. I gave him the promise of negroes, because he is engaged in aiding me to destroy the refugees at Bergen Point. Success there puts it in my power to reward him according to compact. If nothing is done, he is to receive an additional sum of money. The outlines of the scheme, which I have recommended, are, that the sergeant should join General Arnold as a deserter from us, should engage in his corps now raising, and should contrive to insinuate himself into some menial or military berth about the General's person; that a correspondence should be kept up with the man in Newark, by the latter's visiting the former every two days; and that, when the favorable moment arrives, they should seize the prize in the night, gag him, and bring him across to Bergen woods.

"If your Excellency approves of what is done, the sergeant will desert from us to-morrow. A few guineas will be necessary for him. I have advised that no third person be admitted into the virtuous conspiracy, as two appear to me adequate to the execution of it.

"The sergeant is a very promising youth, of uncommon taciturnity, and inflexible perseverance. His connections, and his service in the army from the beginning of the war, assure me that he will be faithful. I have instructed him not to return till he receives directions from me, but to continue his attempts however unfavorable the prospects may appear at first. I have incited his thirst for fame, by impressing on his mind the virtue and glory of the act. I have the honor to be, \&c." 
GENERAL WASHINGTON TO MAJOR LEE.

"Head-Quarters, 20 October, 1780.-Dear Sir: The plan proposed for taking $A-$, the outlines of which are communicated in your letter, which was this moment put into my hands without a date, has every mark of a good one. I therefore agree to the promised rewards, and have such entire confidence in your management of the business, as to give it my fullest approbation; and leave the whole to the guidance of your own judgment, with this express stipulation and pointed injunction, that he $(\mathrm{Ar}-\mathrm{d})$ is brought to me alive. No circumstance whatever shall obtain my consent to his being put to death. The idea, which would accompany such an event, would be that ruffians had been hired to assassinate him. My aim is to make a public example of him; and this should be strongly impressed upon those who are employed to bring him off. The sergeant must be very circumspect; too much zeal may create suspicion; and too much precipitancy may defeat the project. The most inviolable secrecy must be observed on all hands. I send you five guineas; but I am not satisfied of the propriety of the sergeant's appearing with much specie. This circumstance may also lead to suspicion, as it is but too well known to the enemy, that we do not abound in this article.

"The interviews between the party in and out of the city should be managed with much caution and seeming indifference, or else the frequency of their meetings may betray the design, and involve bad consequences; but I am persuaded you will place every matter in a proper point of view to the conductors of this interesting busi- 
ness, and therefore I shall only add, that I am, dear Sir, \&c."

MAJOR LEE TO GENERAL WASHINGTON.

"October 21st.-I have just returned from Newark, where I completed the business your Excellency committed to me. The virtuous sergeant deserted last night. I saw the two in Newark this day. This night they go to York.

"Desertion among us is a perfect stranger. My officers are very attentive, and some of them men of nice discernment. This leads me to apprehend they will discover, that the sergeant is on some secret command. Lest the example may operate on the soldiers, the captains will probably inform their troops of their conclusion. From the soldiers, the same sentiments may reach the people.

"To prevent this, I wish your Excellency would order me to move to a forage country; this is very scarce of hay. I can send two troops, including the one to which the deserter belongs, to an abundant neighborhood back of the Mountain Meeting-House, where they will be safe, and ready for any operation. One troop can remain with me here, which number is adequate to the common duties. Sir Henry Clinton is still in New York. Report says Arnold sailed with the fleet, though this is not credible.

"I have the honor to be, \&c." 
MAJOR LEE TO GENERAL WASHINGTON.

"Light Camp, 25 October, 1780.-My friend got safo into New York. He was before Sir Henry Clinton, and has passed all the forms of the garrison. He accidentally met Colonel Arnold* in the street, which has paved a natural way for further acquaintance. The party entertain high hopes of success. I fear their patience will be exhausted; therefore am of opinion it ought to be impressed on their minds at every meeting. I informed Mr. Baldwin, that I was under orders to march south; that I would see him to-morrow, and send on some officer from you, who should transact the business on your Excellency's part in case of my departure. I also promised him ten or twelve guineas. I was induced to do this, because I apprehended he would fail in his assiduity, unless he received some part of his promised reward. On hearing from your Excellency, I shall be able to-morrow to ascertain with Mr. Baldwin the next interview, the time, the place, and the person. The time and place I will communicate to my successor. Should I leave this army, I entreat your Excellency's attention to my sergeant, and should be happy if he could be sent on to me.

"I beg leave to thank your Excellency, for the confidence and friendship you have been pleased to give me since I became a soldier. I flatter myself I shall enjoy a continuation of it, though absent, and that I shall be called on to perform any services, private or public, you

* Arnold was appointed a colonel in the British service, with the brevet rank of brigadier general. 
may wish to execute, convenient to my local situation, and not superior to my ability or station. I sincerely pray for your health, happiness, and success. May you never again experience a second base desertion, and may you live to put an end to a war, which you have hitherto conducted happily, amidst so many and so great diffculties. I have the honor to be, \&c."

There appears to be a discrepancy between these letters and some parts of the narrative of Champe's adventures, as given in Lee's Memoirs. The sergeant is there represented to have deserted before the execution of André, with the special design of seizing Arnold, and thereby saving André. But the execution of André took place on the $2 \mathrm{~d}$ of October, and it is stated above that the sergeant did not desert till the night of the 20th. It was impossible, therefore, to have been a part of the scheme to save André.

The discrepancy may be explained upon the supposition, that the incidents described by Lee, as occurring previously to this latter date, applied to another person, and that in the lapse of time the transactions in which they were both engaged had become confounded in the writer's memory. This solution is the more probable from the circumstance, that a sergeant, who was one of an escort that accompanied Captain Ogden to Paulus Hook, as the bearer of despatches from General Washington to Sir Henry Clinton, deserted at that place during the night of the 30th of September. (See Life and Treason of Arnold, p. 270.) The sergeant had been instructed to desert, and to act as a spy in New York. 
for certain purposes. It may have been a part of his commission to seize Arnold, should circumstances favor such an enterprise.*

We now proceed to lay before the reader Major Lee's account of Champe's heroic conduct referred to in the above extract from Sparks. We commence at the point where he represents himself as giving instructions to Champe on the evening of his desertion.

We thus proceed:

He was further urged, to bear in constant recollection the solemn injunction so pointedly expressed in the instructions to Major Lee, of forbearing to kill Arnold in any condition of things.

This part of the business being finished, the major and serjeant's deliberation were turned to the manner of the latter's desertion; for it was well known to both that to pass the numerous patrols of horse and foot crossing from the stationary guards, was itself difficult; which was now rendered more so by parties thrown occasionally beyond the place called Liberty Pole, as well as by swarms of irregulars, induced sometimes to venture down to the very point at Paulus Hook with the hope of picking up booty. Evidently discernible as were the difficulties in the way, no relief could be administered by Major Lee, lest it might induce a belief that he was privy to the desertion, which opinion getting to the enemy would involve the life of Champe. The serjeant was left to his own resources and to his own management, with the declared determination, that in case his departure should be discovered before morn* Sparks' Writings of Washington. 
ing, Lee would take care to delay pursuit as long as was practicable.

Giving to the serjeant three guineas, and presenting his best wishes, he recommended him to start without delay, and enjoined him to commmunicate his arrival in New York as soon thereafter as might be practicable. Champe pulling out his watch, compared it with the major's, reminding the latter of the importance of holding back pursuit, which he was convinced would take place in the course of the night, and which might be fatal, as he knew that he should be obliged to zigzag in order to avoid the patrols, which would consume time. It was now nearly eleven. The serjeant returned to camp, and taking his cloak, valise, and orderly book, he drew his horse from the picket, and mounting him put himself upon fortune. Lee, charmed with his expeditious consummation of the first part of the enterprise, retired to rest. Useless attempt! the past scene could not be obliterated; and, indeed, had that been practicable, the interruption which ensued would have stopped repose.

Within half an hour Captain Carnes, officer of the day, waited upon the major, and with considerable emotion told him that one of the patrol had fallen in with a dragoon, who, being challenged, put spur to his horse and escaped, though instantly pursued. Lee complaining of the interruption, and pretending to be extremely fatigued by his ride to and from head-quarters, answered as if he did not understand what had been said, which compelled the captain to repeat it. "Who can the fellow that was pursued be?" inquired the major; adding, "a 
countryman, probably." "No," replied the captain, "the patrol sufficiently distinguished him as to know that he was a dragoon; probably one from the army, if not certainly one of our own." This idea was ridiculed from its improbability, as during the whole war but a single dragoon had deserted from the legion. This did not convince Carnes, so much stress was it now the fashion to lay on the desertion of Arnold, and the probable effect of his example. The captain withdrew to examine the squadron of horse, whom he had ordered to assemble in pursuance of established usage on similar occasions. Very quickly he returned, stating that the scoundrel was known, and was no less a person than the sergeantmajor, who had gone off with his horse, baggage, arms, and orderly book, - so presumed, as neither the one nor the other could be found. Sensibly affected at the supposed baseness of a soldier extremely respected, the captain added that he had ordered a party to make ready for pursuit, and begged the major's written orders.

Occasionally this discourse was interrupted, and every idea suggested which the excellent character of the sergeant warranted, to induce the suspicion that he had not deserted, but had taken the liberty to leave camp with a view to personal pleasure: an example, said Lee, too often set by the officers themselves, destructive as it was of discipline, opposed as it was to orders, and disastrous as it might prove to the corps in the course of service.

Some little delay was thus interposed; but it being now announced that the pursuing party was ready, Major Lee directed a change in the officer, saying that 
he had a particular service in view, which he had determined to entrust to the lieutenant ready for duty and which probably must be performed in the morning. $\mathrm{He}$ therefore directed him to summon Cornet Middleton for the present command. Lee was induced thus to act, first to add to the delay, and next from his knowledge of the tenderness of Middleton's disposition, which he hoped would lead to the protection of Champe, should he be taken. Within ten minutes Middleton appeared to receive his orders, which were delivered to him made out in the customary form, and signed by the major. "Pursue so far as you can with safety sergeant Champe, who is suspected of deserting to the enemy, and has taken the road leading to Paulus Hook. Bring him alive, that he may suffer in the presence of the army; but kill him if he resists, or escapes after being taken."

Detaining the cornet a few minutes longer in advising him what course to pursue,-urging him to take care of the horse and accoutrements, if recovered,-and enjoining him to be on his guard, lest he might, by his eager pursuit, improvidently fall into the hands of the enemy, - the major dismissed Middleton, wishing him success. A shower of rain fell soon after Champe's departure, which enabled the pursuing dragoons to take the trail of his horse; knowing, as officer and trooper did, the make of their shoes, whose impression was an unerring guide.*

* The horses being all shod by our own farriers, the shoes were made in the same form; which, with a private mark annexed to the fore shoes, and known to the troopers, pointed out the trail of our dragoons to each other, which was often very useful. 
When Middleton departed, it was a few minutes past twelve; so that Champe had only the start of rather more than an hour-by no means as long as was desired. Lee became very unhappy, not only because the estimable and gallant Champe might be injured, but lest the enterprise might be delayed; and he spent a sleepless night. The pursuing party during the night, was, on their part, delayed by the necessary halts to examine occasionally the road, as the impression of the horse's shoes directed their course; this was unfortunately too evident, no other horse having passed along the road since the shower. When the day broke, Middleton was no longer forced to halt, and he pressed on with rapidity. Ascending an eminence before he reached the Three Pigeons, some miles on the north of the village of Bergen, as the pursuing party reached its summit, Champe was descried not more than half a mile in front. Resembling an Indian in his vigilance, the sergeant at the same moment discovered the party (whose object he was no stranger to), and giving spur to his horse, he determined to outstrip his pursuers. Middleton at the same instant put his horses to the top of their speed; and being (as the legion all were) well acquainted with the country, he recollected a short route through the woods to the bridge below Bergen, which diverged from the great road just after you gain the Three Pigeons. Reaching the point of separation, he halted; and dividing his party, directed a sergeant with a few dragoons to take the near cut, and possess with all possible despatch the bridge, while he with the residue followed Champe; not doubting but that Champe must deliver himself up, 
as he would be closed between himself and his sergeant. Champe did not forget the short cut, and would have taken it himself, but he knew it was the usual route of our parties when returning in the day from the neighborhood of the enemy, properly preferring the woods to the road. He consequently avoided it; and persuaded that Middleton would avail himself of it, wisely resolved to relinquish his intention of getting to Paulus Hook, and to seek refuge from two British galleys, lying a few miles to the west of Bergen.

This was a station always occupied by one or two galleys, and which it was known now lay there. Entering the village of Bergen, Champe turned to his right, and disguising his change of course as much as he could by taking the beaten streets, turning as they turned, he passed through the village, and took the road towards Elizabethtown Point. Middleton's sergeant gained the bridge, where he concealed himself, ready to pounce upon Champe when he came up; and Middleton, pursuing his course through Bergen, soon got also to the bridge, when, to his extreme mortification, he found that the sergeant had slipped through his fingers. Returning up the road, he inquired of the villagers of Bergen, whether a dragoon had been seen that morning preceding his party. He was answered in the affirmative, but could learn nothing satisfactorily as to the route he took. While engaged in inquiries himself, he spread his party through the village to strike the trail of Champe's horse, a resort always recurred to. Some of his dragoons hit it just as the sergeant, leaving the village, got in the road to the Point. Pursuit was renewed with vigor, and 
again Champe was descried. He, apprehending the event, had prepared himself for it, by lashing his valise (containing his clothes and orderly book) on his shoulders, and holding his drawn sword in his hand, having thrown away its scabbard. This he did to save what was indispensable to him, and to prevent any interruption to his swimming by the scabbard, should Middleton, as he presumed, when disappointed at the bridge, take the measures adopted by him. The pursuit was rapid and close, as the stop occasioned by the sergeant's preparations for swimming had brought Middleton within two or three hundred yards. As soon as Champe got abreast of the galleys, he dismounted, and running through the marsh to the river, plunged into it, calling upon the galleys for help. This was readily given; they fired upon our horse, and sent a boat to meet Champe, who was taken in and carried on board, and conveyed to New York, with a letter from the captain of the galley, stating the past scene, all of which he had seen.

The horse with his equipments, the sergeant's cloak and sword scabbard, were recovered; the sword itself, being held by Champe until he plunged into the river, was lost, as Middleton found it necessary to retire without searching for it.

About three o'clock in the evening our party returned, and the soldiers, seeing the horse (well known to them) in our possession, made the air resound with exclamations that the scoundrel was killed.

Major Lee, called by this heart-rending annunciation from his tent, saw the sergeant's horse led by one of Middleton's dragoons, and began to reproach himself 


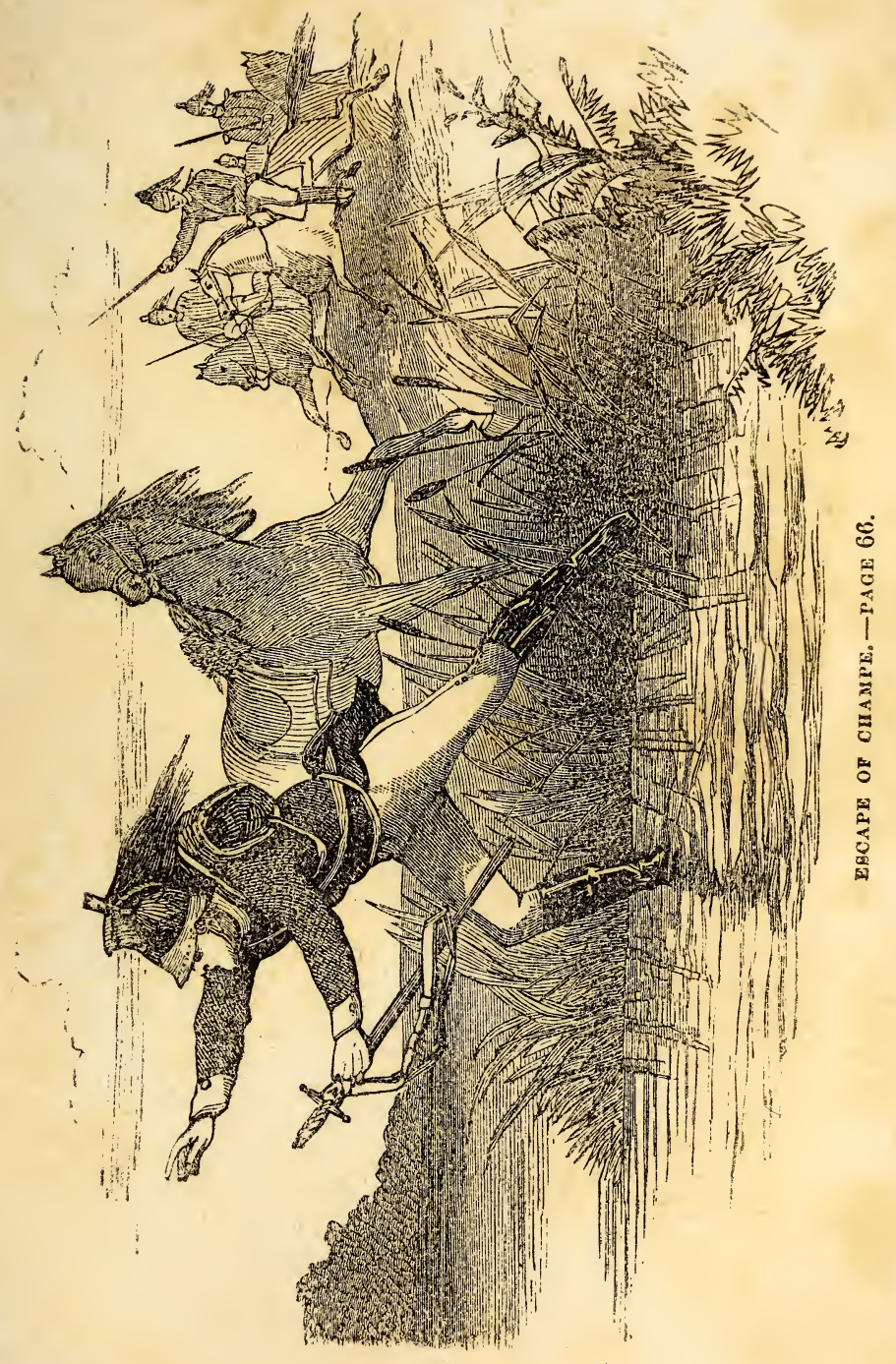



with the blood of the high prized, faithful, and intrepid Champe. Stifling his agony, he advanced to meet Middleton, and became somewhat relieved as soon as he got near enough to discern the countenance of his officer and party. There was evidence in their looks of disappointment, and he was quickly relieved by Middleton's information, that the sergeant had effected his escape with the loss of his horse, and narrated the particulars just recited.

Lee's joy was now as full as, the moment before, his torture had been excruciating. Never was a happier conclusion. The sergeant escaped unhurt, carrying with him to the enemy undeniable testimony of the sincerity of his desertion,-canceling every apprehension before entertained, lest the enemy might suspect him of being what he really was.

Major Lee imparted to the commander-in-chief the occurrence, who was sensibly affected by the hairbreadth escape of Champe, and anticipated with pleasure the good effect sure to follow the enemy's knowledge of its manner.

On the fourth day after Champe's departure, Lee received a letter from him, written the day before in a disguised hand, without any signature, and stating what had passed after he got on board the galley, where he was kindly received.

He was carried to the commandant of New York as soon as he arrived, and presented the letter addressed to this officer from the captain of the galley. Being asked to what corps he belonged, and a few other common questions, he was sent under care of an orderly sergeant 
to the adjutant-general, who, finding that he was sergeant-major of the legion horse, heretofore remarkable for their fidelity, began to interrogate him. He was told by Champe, that such was the spirit of defection which prevailed among the American troops in consequence of Arnold's example, that he had no doubt, if the temper was properly cherished, Washington's ranks would not only be greatly thinned, but that some of his best corps would leave him. To this conclusion, the sergeant said, he was led by his own observations, and especially by his knowledge of the discontents which agitated the corps to which he had belonged. His size, place of birth, his form, countenance, color of his hair, the corps in which he had served, with other remarks, in conformity to the British usage, was noted in a large folio book. After this was finished, he was sent to the commanderin-chief, in charge of one of the staff, with a letter from the adjutant-general. Sir Henry Clinton treated him very kindly, and detained him more than one hour, asking him many questions, all leading, - first to know to what extent this spirit of defection might be pushed by proper incitements, - what were the most operating incitements,-whether any general officers were suspected by Washington as concerned in Arnold's conspiracy, or any other officers of note;-who they were, and whether the troops approved or censured Washington's suspicions; -whether his popularity in the army was sinking, or continued stationary. What was Major Andre's situation, -whether any change had taken place in the manner of his confinement, - what was the current opinion of his probable fate,-and whether it was thought Washington 
would treat him as a spy. To these various interrogations, some of which were perplexing, Champe answered warily; exciting, nevertheless, hopes that the adoption of proper measures to encourage desertion 'of which he could not pretend to form an opinion) would certainly bring off hundreds of the American soldiers, including some of the best troops, horse as well as foot. Respecting the fate of Andre, he said he was ignorant, though there appeared to be a general wish in the army that his life should not be taken; and that he believed it would depend more upon the disposition of Congress, than on the will of Washington.

After this long conversation ended, Sir Henry presented Champe with a couple of guineas, and recommended him to wait upon General Arnold, who was engaged in raising an American Legion in the service of his majesty. He directed one of his aids to write to Arnold by Champe, stating who he was, and what he had said about the disposition in the army to follow his example; which, very soon done, it was given to the orderly attending on Champe, to be presented with the deserter to General Arnold. Arnold expressed much satisfaction on hearing from Champe the manner of his escape, and the effect of Arnold's example, and concluded his numerous inquiries by assigning quarters to the sergeant, - the same as were occupied by his recruiting sergeants.

He also proposed to Champe to join his legion, telling him he would give to him the same station he had held in the rebel service, and promising further advancement when merited. Expressing his wish to retire from war, 
and his conviction of the certainty of his being hung if ever taken by the rebels, he begged to be excused from enlistment, assuring the general, that should he change his mind, he would certainly accept his offer. Retiring to the assigned quarters, Champe now turned his attention to the delivery of his letters, which he could not effect until the next night, and then only to one of the two incogniti to whom he was recommended. This man received the sergeant with extreme attention, and having read the letter, assured Champe that he might rely on his faithful coöperation in doing everything in his power consistent with his safety, to guard which required the utmost prudence and circumspection. The sole object in which the aid of this individual was required, regarded the general and others of our army, implicated in the information sent to Washington by him. To this object Champe urged his attention, assuring him of the solicitude it had excited, and telling him that its speedy investigation had induced the general to send him into New York. Promising to enter upon it with zeal, and engaging to send out Champe's letters to Major Lee, he fixed the time and place for their next meeting, when they separated.

Lee made known to the general what had been transmitted to him by Champe, and received in answer directions to press Champe to the expeditious conclusion of his mission, as the fate of Andre would be soon decided, when little or no delay could be admitted in executing whatever sentence the court might decree. The same messenger who brought Champe's letter, returned with the ordered communication. Five days had nearly 
elapsed after reaching New York, before Champe saw the confidant to whom only the attempt against Arnold was to be entrusted. This person entered with promptitude into the design, promising his cordial assistance. To procure a proper associate to Champe was the first object, and this he promised to do with all possible despatch. Furnishing a conveyance to Lee, we again heard from Champe, who stated what I have related, with the additional intelligence that he had that morning (the last of September) been appointed one of Arnold's recruiting sergeants, having enlisted the day before with Arnold, and that he was induced to take this afflicting step for the purpose of securing uninterrupted ingress and egress to the house which the general occupied, it being indispensable to a speedy conclusion of the difficult enterprise which the information he had just received had so forcibly urged. He added, that the difficulties in his way were numerous and stubborn, and that his prospect of success was by no means cheering. With respect to the additional treason, he asserted that he had every reason to believe that it was groundless; that the report took its rise in the enemy's camp, and that he hoped soon to clear up that matter satisfactorily. The pleasure which the last part of this communication afforded, was damped by the tidings it imparted respecting Arnold, as ou his speedy delivery depended Andre's relief. The interposition of Sir Henry Clinton, who was extremely anxious to save his much loved aide-de-camp still continued; and it was expected the examination of witnesses, and the defence of the prisoner, would protract the decision of the court of inquiry now assembled, and 
give sufficient time for the consummation of the project committed to Champe. A complete disappointment took place from a quarter unforeseen and unexpected. The honorable and accomplished Andre, knowing his guilt, disdained defence, and prevented the examination of witnesses by confessing the character in which he stood. On the next day (the 2nd of October) the court again assembled, when every doubt that could possibly arise in the case having been removed by the previous confession, Andre was declared to be a spy, and condemned to suffer accordingly.*

The sentence was executed on the subsequent day in the usual form; the commander-in-chief deeming it improper to interpose any delay. In this decision he was warranted by the very unpromising intelligence received from Champe; by the still existing implication of other officers in Arnold's conspiracy, by a due regard to public opinion, and by real tenderness to the condemned.

Neither Congress ncr the nation could have been with propriety informed of the cause of the delay, and without such information it must have excited in both alarm and suspicion. Andre himself could not have been entrusted with the secret, and would consequently have attributed the unlooked for event to the expostulation and exertion of Sir Henry Clinton, which would not fail to produce in his breast expectations of ultimate relief; to excite which would have been cruel, as the realization of such expectation depended upon a possible but improbable contingency. The fate of Andre, hastened by himself, deprived the enterprise committed to Champe of a fea-

* Lee's mistake about dates has already been noticed. 
ture which had been highly prized by its projector, and which had very much engaged the heart of the individual chosen to execute it.

Washington ordered Major Lee to communicate what had passed to the sergeant, with directions to encourage him to prosecute with unrelaxed vigor the remaining objects of his instructions, but to intermit haste in the execution only as far as was compatible with final success.

This was accordingly done by the first opportunity, in the manner directed. Champe deplored the sad necessity which occurred, and candidly confessed that the hope of enabling Washington to save the life of Andre, (who had been the subject of universal commiseration in the American camp,) greatly contributed to remove the serious difficulties which opposed his acceding to the proposition when first propounded. Some documents accompanied this communication, tending to prove the innocence of the accused general; they were completely satisfactory, and did credit to the discrimination, zeal, and diligence of the sergeant. Lee inclosed them immediately to the commander-in-chief, who was pleased to express the satisfaction he derived from the information, and to order the major to wait upon him the next day; when the whole subject was re-examined, and the distrust heretofore entertained of the accused was forever dismissed. Nothing now remained to be done, but the seizure and safe delivery of Arnold. To this object Champe gave his undivided attention; and on the 19th October, Major Lee received from him a very particular account of the progress he had made, with the outlines of his plan. This was, without delay, submitted to 
Washington, with a request for a few additional guineas. The general's letter, written on the same day, (20th October) evinces his attention to the minutia of business, as well as his immutable determination to possess Arnold alive, or not at all. This was his original injunction, which he never omitted to enforce upon every proper occasion.

Major Lee had an opportunity in the course of the week of writing to Champe, when he told him that the rewards which he had promised to his associates would be certainly paid on the delivery of Arnold; and in the mean time, small sums of money would be furnished for casual expenses, it being deemed improper that he should appear with much, lest it might lead to suspicion and detection. That five guineas were now sent, and that more would follow when absolutely necessary.

Ten days elapsed before Champe brought his measures to conclusion, when Lee received from him his final communication, appointing the third subsequent night for a party of dragoons to meet him at Hoboken, when he hoped to deliver Arnold to the officer. Champe had, from his enlistment into the American legion (Arnold's corps) every opportunity he could wish, to attend to the habits of the general. He discovered that it was his custom to return home about twelve every night, and that previous to going to bed he always visited the garden. During this visit the conspirators were to seize him, and being prepared with a gag, intended to have applied the same instantly.

Adjoining the house in which Arnold resided, and in which it was designed to seize and gag him, Champe 
had taken off several of the palings and replaced them, so that with care and without noise he could readily open his way to the adjoining alley. Into this alley he meant to have conveyed his prisoner, aided by his companion, one of two associates who had been introduced by the friend to whom Champe had been originally made known by letter from the commander-in-chief, and with whose aid and counsel he had so far conducted the enterprise. His other associate was with the boat prepared at one of the wharves on the Hudson river, to receive the party.

Champe and his friend intended to have placed themselves each under Arnold's shoulder, and to have thus borne him through the most unfrequented alleys and streets to the boat; representing Arnold, in case of being questioned, as a drunken soldier whom they were conveying to the guard-house.

When arrived at the boat the difficulties would be all surmounted, there being no danger nor obstacle in passing to the Jersey shore. These particulars as soon as known to Lee, were communicated to the commander-in-chief, who was highly gratified with the much desired intelligence. He directed Major Lee to meet Champe, and to take care that Arnold should not be hurt. The day arrived, and Lee with a party of dragoons left camp late in the evening, with three led accoutred horses; one for Arnold, one for the sergeant, and the third for his associate, never doubting the success of the enterprise, from the tenor of the last received communication. The party reached Hoboken about midnight, where they were concealed in the adjoining wood,-Lee with three dragoons 
stationing himself near the river shore. Hour after hour passed,-no boat approached. At length the day broke and the major retired to his party, and with his led horses returned to camp, when he proceeded to head-quarters to inform the general of the much lamented disappointment, as mortifying as inexplicable. Washington having perused Champe's plan and communication, had indulged the presumption that at length the object of his keen and constant pursuit was sure of execution, and did not dissemble the joy such conviction produced. He was chagrined at the issue, and apprehended that his faithful sergeant must have been detected in the last scene of his tedious and difficult enterprise.

In a few days, Lee received an anonymous letter from Champe's patron and friend, informing him that on the day preceding the night fixed for the execution of the plot, Arnold had removed his quarters to another part of the town, to superintend the embarkation of troops preparing (as was rumored) for an expedition to be directed by himself; and that the American legion, consisting chiefly of American deserters, had been transferred from their barracks to one of the transports; it being apprehended that if left on shore until the exped: tion was ready, many of them might desert. Thus it happened that John Champe, instead of crossing the Hudson that night, was safely deposited on board one of the fleet of transports, from whence he never departed until the troops under Arnold landed in Virginia! Nor was he able to escape from the British army until after the junction of Lord Cornwallis at Petersburg, when he deserted; and proceeding high up into Virginia 
he passed into North Carolina near the Saura towns, and keeping in the friendly districts of that state, safely joined the army soon after it had passed the Congaree in pursuit of Lord Rawdon.

His appearance excited extreme surprise among his former comrades, whic' was not a little increased when they saw the cordial reception he met with from the late Major now Lieutenant Colonel Lee. His whole story soon became known to the corps, which reproduced the love and respect of officer and soldier (heretofore invariably entertained for the sergeant), heightened by universal admiration of his late daring and arduous attempt.

Champe was introduced to General Greene, who very cheerfully complied with the promises made by the commander-in-chief, as far as in his power; and having provided the sergeant with a good horse and money for his journey, sent him to General Washington, who munificently anticipated every desire of the sergeant and presented him with his discharge from further service,* lest he might, in the vicissitudes of war, fall into the enemy's hands; when, if recognized, he was sure to die on a gibbet.

* When General Washington was called by President Adams to the command of the army, prepared to defend the country from French hostility, he sent to Lieutenant Colonel Lee to inquire for Champe, being determined to bring him into the field at the head of a company of infantry.

Lee sent to London county, where Champe settled after his discharge from the army; when he learned that the gallant soldier had removed to Kentucky, where he soon after died. 


\section{CHAPTER VI.}

Congress retains Lee's Legion in remodeling the army-Lee advanced to the rank of Lieutenant Colonel-Ordered to join the Southern Army under General Greene-Washington's opinion of Lee-General Greene proceeds to Richmond and Hillsborough-Account of North Carolina-Greene joins the army at Charlotte--Gates resigns the command to Greene and proceeds to Richmond-Noble conduct of the Virginia Legislature towards him-Condition of the army-Character and appearance of General Greene-His disposition of the forces-General Washington's successful stratagem at Rugley's farm - Army leave Charlotte-Greene takes a position on the Pedee near Cheraw Hill.

ON the $3 \mathrm{~d}$ of October, 1780, Congress passed resolutions containing a plan for a new arrangement of the army, and by a separate resolve they were referred to the commander-in-chief for his opinion.

On the 11th of October, Washington, in a letter to the President of Congress, gave a written opinion on the new arrangement, and communicated his views on every part of it with that clearness and thorough understanding, which he was accustomed to evince on all public affairs. In this letter he says :

"Besides the four regiments, I cannot forbear recommending, that two partisan corps may be kept up, commanded by Colonel Armand and Major Lee. Though 
in general I dislike independent corps, I think a partisan corps with an army useful in many respects. Its name and destination stimulate to enterprise; and the two officers I have mentioned have the best claims to public attention. Colonel Armand is an officer of great merit, which, added to his being a foreigner, to his rank in life, and to the sacrifices of property he has made, renders it a point of delicacy as well as justice to continue to him the means of serving honorably. Major Lee has rendered such distinguished services, possesses so many talents for commanding a corps of this nature, and deserves so much credit for the perfection in which he has kept his corps, as well as for the handsome exploits he has performed, that it would be a loss to the service, and a discouragement to merit, to reduce him, and I do not see how he can be introduced into one of the regiments in a manner satisfactory to himself, and which will enable him to be equally useful, without giving too much disgust to the whole line of cavalry.

"The partisan corps may consist of three troops of mounted and three of dismounted dragoons, of fifty each, making in all three hundred."

Washington's recommendation was attended to, and Major Lee's corps was retained. About the same time he was advanced to the rank of lieutenant colonel. Before the close of the month he was under marching orders for the south, to join the army of General Greene, who had just been appointed to the command of the southern army in place of General Gates.

Writing to a member of Congress,(October 23, 1780,) 
Washington says, "Lee's corps will go to the southward. I believe it will be found very useful. The corps itself is an excellent one, and the officer at the head of it has great resources of genius." This was a great deal for Washington to say of any man. But Lee never gave him reason to change his opinion, and never lost his confidence. The opinion above expressed respecting his future usefulness was fully justified by Lee's brilliant successes in the southern campaigns.

Making Lieutenant Colonel Lee his bwn biographer for this portion of the narrative, we now proceed to quote from his "Memoirs of the War in the Southern Department of the United States," his own account of some of the more important movements of the southern army under General Greene, to which Lee's Legion was now attached.

General Greene, after employing a few days in preparing for his journey, relinquished, with reluctance, his inferior station to take upon himself the honorable though weighty command to which he had been called. He passed through the states of Maryland and Delaware, for the purpose of ascertaining the extent of the assistance to be obtained from that quarter.

Here he was informed that Brigadier Gist had been indefatigably engaged in executing the trust reposed in him ; but such was the difficulty at this period of procuring recruits as to forbid the expectation of filling up the regiments without the substitution of some new mode. On this, and all other subjects, connected with his duty, he held full and free conferences with the state govern- 
ments ; and having made his final arrangements, pursued his journey to Richmond, the capital of Virginia.

When Greene reached Richmond, he found the government engaged in preparing means of defence against Leslie, who had established himself at Portsmouth. Relying upon this state for his principal support in men and stores, he was sensibly affected by the difficulties in which he found her. But active and intelligent, penetrating and laborious, he persevered in his exertions. Having brought his arrangements to a satisfactory conclusion, he proceeded south, leaving Major General Baron Steuhen to direct the defence of Virginia, and to superintend the reinforcements preparing for the southern army. From Richmond he hastened to Hillsborough, the seat of government of North Carolina. Here he found the executive, apprised of the dangers by which the state was threatened, well disposed to exert their authority in preparing means to resist the advancing enemy. This state very much resembles Virginia in the manners and habits of the people, so much so as to induce the conclusion of its being settled principally by emigrants from that state. Its population, though double that of South Carolina, was very disproportionate to the extent of its territory.

North Carolina is watered by many rivers; few of which are navigable for ships. Cape Fear is the most considerable; and that only navigable to Wilmington, situated not very distant from the sea. In a state of war, when naval superiority is conclusively in favor of the enemy, as was the case in our contest, this privation of nature was replete with advantage to us, though 
extremely incommodious in peace. This state is only to be assailed with effect through Virginia or South Carolina, through each of which her foreign commerce passes. At present it was threatened on both sides, as Leslie still continued in Virginia, waiting, as was presumed, for the advance of Lord Cornwallis. Although in this state, horses, bacon, Indian corn, and beef, which constitute the most essential supplies of an army, could be found in abundance, yet, from the thinness of population, the collection of them was inconvenient.

The mountainous region of North Carolina was inhabited by a race of hardy men, who were familiar with the use of the horse and rifle, were stout, active, patient under privation, and brave. Irregular in their movements, and unaccustomed to restraint, they delighted in the fury of action, but pined under the servitude and inactivity of camp. True to the American cause, they displayed an impetuous zeal, whenever their wild and ardent temper prompted the contribution of their aid. In the middle and Atlantic sections lived a race, less capable of labor, and less willing to endure it; who were much divided in political opinions, and incumbered with that dreadful evil, which the cruel policy of preceding times had introduced. The prospect of efficient aid from a state so situated, was not encouraging. But the fertile genius of Greene, deriving new influence from his conciliating manners, soon laid the foundation of a support, which would have been completely adequate to his purpose, had the quality of the troops corresponded with their number. Having finished his preparatory measures, he hastened to Charlotte, pleased with the hope 
of rescuing the state from the impending calamities. On the $2 \mathrm{~d}$ of December, 1780 , he reached the army, and was received by General Gates with the most cordial respect. The translation of the command was announced in general orders on the ensuing day. After devoting a short time to those communications, which were essential to the information of his successor, Gates took leave of the army, and proceeded to meet the inquiry into his conduct, which had been ordered by Congress. His progress was slow, his manners were grave, his demeanor was condescending, his conversation reserved. On his long road, no countenance shed the balm of condolence; all were gloomy, all scowling. The fatal loss on the 18th of August was acutely remembered; but the important victory of Saratnga was forgotten. The unfortunate general at length reached Richmond, where the general assembly of Virginia was in session. Great and good men then governed the state. Instructed by history, guided by the dictates of virtue, and grateful for eminent services, they saw a wide difference between misfortune and criminality, and weighed the exploits in the North against the disasters in the South. These fathers of the commonwealth appointed a committee of their body to wait on the vanquished general, and "to assure him of their high regard and esteem : that their remembrance of his former glorious services was never to be obliterated by any reverse of fortune; but, ever mindful of his great merit, they would omit no opportunity of testifying to the world the gratitude which Virginia, as a member of the American Union, owed to him in his military character." 
General Gates had supported his fall from splendid elevation to obscurity, with apparent fortitude and complacency. He was sensibly affected and comforted by this kind reception, and retired to his farm in the county of Berkeley, where the keen regrets of disappointment and misfortune were softened by the soothing occupations of agriculture, and the condolence of the state in which he resided.

General Greene directed his whole attention to the high duties of his command. On reviewing his army, he found its total not more than two thousand, of which the major part was militia. Notwithstanding the exertions of his predecessor to establish magazines, he found three days' provision only on hand, and the country around him exhausted. His supply of ammunition was very scanty; and Virginia was the nearest point from which a replenishment could be obtained.

Such means and resources badly comported with the grand design of arresting the progress of the conqueror, and restoring the two lost states to the Union. Capable of doing much with little, Greene was not discouraged by this unfavorable prospect. His vivid plastic genius soon operated on the latent elements of martial capacity in his army, invigorated its weakness, turned its confusion into order, and its despondency into ardor. A wide sphere of intellectual resource enabled him to inspire confidence, to rekindle courage, to decide hesitation, and infuse a spirit of exalted patriotism in the citizens of the state. By his own example, he showed the incalculable value of obedience, of patience, of vigilance, and temperance. Dispensing justice, with an even hand, 
to the citizen and soldier; benign in heart, and happy in manners; he acquired the durable attachment and esteem of all. He collected around his person, able and respectable officers; and selected for the several departments, those who were best qualified to fill them. His operations were then commenced with a boldness of design, well calculated to raise the drooping hopes of his country, and to excite the respect of his enemy.

This illustrious man had now reached his thirty-eighth year. In person he was rather corpulent, and above the common size. His complexion was fair and florid; his countenance serene and mild, indicating a goodness which seemed to shade and soften the fire and greatness of its expression. His health was delicate, but preserved by temperance and regularity.

The British army still remained at Winnsborough. General Greene determined to draw in the detachment under Smallwood, which was advanced some distance in his front, and to risk the division of his force by taking two distant positions on each flank of the British army.

Previous to this movement, Brigadier Morgan, who commanded the van of Smallwood's detachment, attempted to strike a foraging party of the enemy, which had penetrated the country between the two armies. But the vigilant adversary eluded the blow, and returned in safety to Camden, Lieutenant Colonel Washington, at the head of the cavalry, having taken a more extensive range than the infantry, discovered that a party of loyalists were stationed at Rugeley's farm about twelve miles from Camden. He moved instantly towards them, in expectation of carrying the post by surprise; 
but in this he was disappointed, as they occupied a barn, surrounded by abattis, and secure from any attempt of cavalry. Rugeley and his friends were delighted with the safety their precaution had produced, and viewed the approach of horse with indifference. Short was their repose. Washington, well informed of the character of his enemy, shaped the trunk of a tree in imitation of a field piece; and, bringing it up in military style, affected to prepare to cannonade the barn. To give solemnity to the device, he sent in a flag, warning the garrison of the impending destruction, which could be only avoided by immediate submission. Not prepared to resist artillery, Colonel Rugeley seized with promptitude the auspicious opportunity; and, with his garrison, one hundred men surrendered at discretion! No circumstance can more strongly demonstrate the propriety of using every effort in war. A soldier should intimately know the character of his enemy, and mould his measures accordingly. This stratagem of Washington, although conceived and executed with little hope of success, was completely successful; and enabled him to effect an object, which, at first view, most would have abandoned as clearly unattainable.

The return of Smallwood's detachment to camp was followed by the immediate departure of the army from Charlotte. The division, intended for operations in the western quarter, was composed of four hundred continental infantry under Lieutenant Colonel Howard, of the Maryland line, two companies of the Virginia militia under Captains Triplett and Taite, and the remnants of the first and third regiments of dragoons, one hundred in 
number, under Lieutenant Colonel Washington. It was placed under the care of Brigadier General Morgan, who was to be strengthened on his march by bodies of mountain militia from Carolina and Georgia. He was ordered to pass the Catawba, and take post in the country between the Broad and Pacolet rivers. Greene, with the main body, moved down the Pedee, and took a position on its eastern bank, nearly opposite Cheraw hill. By this disposition, General Greene secured an abundance of wholesome provisions for his troops; afforded safe rendezvous for the militia in the East and West, on whose aid he necessarily relied; re-excited by his proximity the spirit of revolt, which preceding events had repressed; menaced the various posts of the enemy, and their intermediate communications; and compelled Lord Cornwallis to postpone his advance into North Carolina, until he should have cleared the country to the west of his enemy. 


\section{CHAPTER VII.}

Lee's Legion joins the army under Greene-Surprises GeorgetownBattle of Cowpens-Cornwallis prepares to pursue Greene's army by destroying a part of his bagage and stores-Greene joins Morgan and brings forward his detachment to the main army-The pursuit commences-Defeat of Davidson-Greene passes the Yadkin-Lee with his legion joins Greene's main army-Placed between the retreating and advancing armies-Lee dissuades Morgan from leaving the army-But Morgan retires on account of ill' health.

We have noticed the movements of Lee, detailed in the last chapter, with a view to the reader's better comprehension of the events now to follow, in which Lee was to take an active part. We resume our quotations from Lee's Memoirs.

Soon after General Greene had taken his position opposite to Cheraw hill, Lieutenant Colonel Lee, with his legion, making about two hundred and eighty in horse and foot, joined the army. This corps, being in excellent condition, was, on the next day, ordered to cross the Pedee, in order to support Brigadier Marion, who continued to interrupt and harass the enemy's posts between the Pedee and the Santee. In a few days after Lee's junction with Marion, they projected an enterprise against the garrison of Georgetown, a small village 
in South Carolina, situated on the bay into which the Pedee empties. Colonel Campbell commanded in this town, with a garrison of two hundred men. In his front he had prepared some slight defences, better calculated to repel a sudden, than resist a determined, assault. Between these defences and the town, and contiguous to each, was an inclosed work with a frize and palisade, which constituted his chief protection. A subaltern guard held it. The rest of the troops were dispersed in light parties in and near the town, looking towards the country. The plan of assault was founded on the facility with which the assailant might convey down the Pedee a part of his force undiscovered, and land in the water suburb of the town, which, being always deemed secure, was consequently unguarded. After this body should have reached the wharves, it was to move in two divisions. The first was to force the commander's quarters, known to be the place of parade, then to secure him, and all who might flock thither on the alarm. The second was to be charged with the interception of such * of the garrison as might attempt to gain the fort, their chief point of safety on annoyance. The militia and cavalry of the legion, under Marion and Lee, were to approach near the town in the night; and when the entrance of the infantry, passed down by water, should be announced, they were to rush into it for co-operation and support.

The plan being approved by General Greene, preparations were immediately made for its execution. The infantry of the legion were embarked in boats under the command of Captain Carnes, with orders to fall down the 
Pedee to a designated island, during the first night; to land and lay concealed there the ensuing day; to reëmbark at an early hour of the night following, and reach Georgetown between one and two in the morning.

Marion and Lee proceeded to their destination, having taken all the requisite precautions to prevent any intimation to the enemy of their approach. At twelve o'clock in the second night, they occupied, unperceived, a position in the vicinity of the town, and waited anxiously for the annunciation of Carnes's arrival. This officer met with no difficulty in descending the river, and reached the appointed island before dawn of light. He remained there the ensuing day; and so unusual is inland navigation in South Carolina, so impervious are the deep swamps which line its rivers, that he might have sojourned for weeks on the island without discovery.

Gaining his place of destination with precision in point of time, he landed unperceived, and instantly advanced to the quarters of Lieutenant Colonel Campbell. The commandant was secured; and Carnes judiciously posted his division for seizing such parties of the garrison as might flock to the parade ground. Captain Rudulph, who led the second division, with equal good fortune gained the vicinity of the fort; and arranged his troops on the route of communication, in order to arrest the fugitives.

On the first fire, which took place at the commandant's quarters, the militia of Marion and the dragoons of Lee rushed into the town, prepared to bear down all resistance. To the astonishment of these officers, every thing was quiet; the legion infantry holding its assigned 
stations, and Lieutenant Colonel Campbell a prisoner. Not a British soldier appeared; not one attempted either to gain the fort, or repair to the commandant. Having discovered their enemy, the troops of the garrison kept close to their respective quarters, barricaded the doors, and determined there to defend themselves. The assailants were unprovided with the requisite implements for battering doors and scaling windows. The fort was in possession of the enemy, and daylight approaching.

Marion and Lee were therefore compelled to retire with a partial accomplishment of their object. Colonel Campbell was suffered to remain on parole; and the troops withdrew from Georgetown, unhurt and unannoyed. The plan of this enterprise, although conceived with ingenuity, and executed with precision, was too refined and complicated for success. Marion and Lee were singularly tender of the lives of their soldiers; and preferred moderate success, with little loss, to the most brilliant enterprise, with the destruction of many of their troops.

This principle is wise and commendable; but, when carried too far, it is sure to produce disappointment. If, instead of placing Rudulph's division to intercept the fugitives, it had been ordered to carry the fort by the bayonet, our success would have been complete. The fort taken, and the commandant a prisoner, we might have availed ourselves of the cannon, and have readily demolished every obstacle and shelter.

On the 17th of January, 1781, was fought the celebrated Battle of Cowpens, in which General Morgan defeated a detachment of the British army under Colonel 
Tarleton, which had been sent in pursuit of him. Lee gives a very vivid description of this battle; but his legion was not engaged in it.

Lord Cornwallis, says Lee, ${ }^{*}$ received the unexpected, doleful tidings of Tarleton's defeat with serenity, but deep regret. He had been baffled in his first expedition into North Carolina by the fall of Ferguson; and this late disaster seemed to forbid perseverance in his second. With a view to retrieve, by the celerity of his movements, the severe loss he had sustained, he formed the wise resolution of converting his army into light troops, by the destruction of his baggage. Commanding this sacrifice without respect to persons, he set the example himself, by committing to flames the baggage of headquarters. With zeal and alacrity his faithful army obeyed the mandate. Everything was destroyed, save a small supply of clothing, and a sufficient number of wagons for the conveyance of hospital stores, of salt, of ammunition, and for the accommodation of the sick and wounded. We are at a loss whether to admire more the wisdom of the chief, or the self-denial of his followers. A memorable instance, among many others in this unnatural war, of the immutable disposition of the British soldiers to endure every privation in support of their king and country. This arrangement being finished, Lord Cornwallis moved from Fisher's Creek, determined on unceasing efforts to destroy Morgan, and recover his lost troops; to keep separate the two divisions of Greene's army; and, should he fail in these attempts, to bring. Lee to action before he could reach Virginia.

* Memoirs. 
Morgan, always attentive to his duty, took measures for retreat the moment victory had declared in his favor. In the evening of the same day, he crossed the Broad river, and moved by forced marches to the Catawba, before Lord Cornwallis could reach its banks.

General Greene was quickly advised of the advance of the British army from Winnsborough and Camden, through the upper country; and accordingly issued his preparatory orders for movement. On the subsequent day he received the gratifying intelligence of the victory at the Cowpens. Foreseeing the enemy's objects, he hastened his march in conformity with his previous disposition, and despatched a courier to Marion and Lee, apprising them of his decampment, and ordering the latter to rejoin with all possible celerity. Escorted by a few dragoons, General Greene hastened to reach Morgan, which he happily accomplished on the last day of January, after that officer had passed the Catawba. Aware of the rapidity with which the British general would advance to strike him before he could gain that point, Morgan redoubled his exertions to reach it; but with all his activity, so keen and persevering had been Cornwallis's pursuit, that he had just crossed the river on the evening of the 29th of January, when the British van appeared on the opposite banks. A heary fall of rain, during the night, rendered the Catawba unfordable. Morgan availed himself of this fortunate occurrence; and continuing in his position during the swell of the river, sent off his prisoners, with the arms, stores, \&c., taken at the Cowpens, under the protection of a part of his militia, on a route nearer to the mountain than that 
intended to be taken by himself. The waters continued high for two days, and gave the brigadier time to place his prisoners in safety. His light troops, joined by some of the neighboring militia, were disposed, by order of General Greene, to dispute the passage of the river. This was attempted with a hope of retarding the British general in his advance so long as to allow time for Brigadier Huger, of South Carolina, who had succeeded Smallwood after the retirement of that officer from Charlotte, to reach Salisbury, the first point assigned for the junction of the two divisions of the American army.

As soon as the fall of the water admitted the passage of troops, Lord Cornwallis resumed his march.

Now commenced that celebrated retreat of General Greene before the superior army of Cornwallis, which is considered the most able and important of all his splendid achievements in the Southern States.

On the first of February, Cornwallis encountered at McCowan's Ford, a detachment under General Davidson, sent by Greene to dispute the passage. An action ensued in which Davidson was killed and the detachment defeated, and a party of militia at Terrant's tavern in the neighborhood, were dispersed by Tarleton's troopers. Soon after ensued the remarkable passage of the Yadkin, thus related by Lee:

The inhabitants of this region of the state were well affected to the American cause; and General Greene had flattered himself with an expectation of here drawing around him reinforcements, which, with the light troops under Morgan, would enable him to hold Lord 
Cornwallis back for some days. But the fall of Davidson, and the rencontre at Terrant's tavern, disappointed, in their effect, this fond calculation. He despatched orders to Brigadier Huger to relinquish the route to Salisbury, and to take the direct course to Guilford court-house, to which point he pressed forward with the light corps under Morgan. Passing through Salisbury, he proceeded to the trading ford on the Yadkin, where he arrived on the night of the second of February.

General Greene having withdrawn his troops from Beattie's ford, on his lordship's passage above, Lieutenant Colonel Webster and his division crossed the Catawba without oposition, and in the course of the day joined the British general. Cornwallis had now gained the great road, leading to Salisbury; and the pursuit of our light troops was renewed with activity.

General Greene passed the Yadkin during the night of, and day following, his arrival at that river. The horse forded the stream, the infantry and most of the baggage were transported in flats. A few wagons fell into the hands of the enemy; for, notwithstanding the unfavorable condition of the roads and weather, Brigadier O'Hara pressed forward with the British van, and overtook our rear guard. The retreating corps was again placed in a critical situation, and Heaven was again propitious. The rain continued during the night; the Yadkin became unfordable; and Greene had secured all the flats on its northern banks.*

* 'T'o an attentive observer of the events during our war, very many strong exemplifications of providential succor occur, besides the two just noticed. 
The British general was a second time delayed by an unforeseen event. Relinquishing his anxious wish to bring the light troops to action before their junction with the main body, he recurred to his last expedient, that of cutting Greene off from the upper fords of the Dan, and compelling his united force to battle, before he could either reach Virginia, or derive any aid from that state. With this view, he moved up the Yadkin to fords, which were still passable. There his lordship crossed; and, directing his course to the Dan, held Greene on his right, with a determination to throw the American general on the lower Dan, which the great fall of rain had rendered impassable without the assistance of boats, which he supposed unattainable. This object, his last hope, the British general pursued with his accustomed rapidity.

Greene was neither less active, nor less diligent. Continuing on the direct road to Guilford court-house, he reached that place on the 7 th of February. Brigadier Huger, who had been overtaken by the legion of Lee, arrived on the same day. The united force of Greene, including five hundred militia, exceeded two thousand three hundred; of which, two hundred and seventy were cavalry of the best quality. The army of Cornwallis was estimated at two thousand five hundred; but his cavalry, although more numerous than that of his adversary, was far inferior in regard to the size, condition, and activity of the horses. Taking into view his comparative weakness, General Greene determined to continue his retreat to Virginia. The British general was twenty-five miles from Guilford court-house; 
equally near with Greene to Dix's ferry on the Dan, and nearer to the upper shallows or points of that river, which were supposed to be fordable, notwithstanding the late swell of water. Lieutenant Colonel Carrington, quartermaster general, suggested the propriety of passing at Irwin's ferry, seventy miles from Guilford courthouse, and twenty below Dix's. Boyd's ferry was four miles below Irwin's; and the boats might be easily brought down from Dix's to assist in transporting the army at these near and lower ferries. The plan of Lieutenant Colonel Carrington was adopted, and that officer was charged with the requisite preparations. The route of retreat being determined, the place of crossing designated, and measures taken for the collection of boats, General Greene formed a light corps, consisting of some of his best infantry under Lieutenant Colonel Howard, of Washington's cavalry, the legion of Lee, and a few militia riflemen, making in all seven hundred. These troops were to take post between the retreating and the advancing armies to hover round the skirts of the latter, to seize every opportunity of striking in detail, and to retard the enemy by vigilance and judicious positions; while Greene, with the main body, hastened towards the Dan, the boundary of his present toils and dangers.

The command of the light corps was offered to Brigadier Morgan, whose fitness for such a service was universally acknowledged, and whose splendid success had commanded the high confidence of the general and army. Morgan declined the arduous task; and being at that time afflicted, as he ocasionally was, with rheumatism, intimated a resolution of retiring from the army. Greene 
listened with reluctance to the excuse, and endeavored to prevail on him to recede from his determination. Lieutenant Colonel Lee, being in habits of intimacy with Morgan, was individually deputed to persuade him to obey the universal wish. Many common-place arguments were urged in conversation without success. Lee then represented, that the brigadier's retirement at that crisis might induce an opinion unfavorable to his patriotism, and prejudicial to his future fame ; that the resignation of a successful soldier at a critical moment was often attributed, and sometimes justly, to an apprehension that the contest would ultimately be unfortunate to his country, or to a conviction that his reputation had been accidentally acquired, and could not survive the vicissitudes of war. These, observations appeared to touch the feelings of Morgan : for a moment he paused; then discovered a faint inclination to go through the impending conflict; but finally returned to his original decision. His refusal of the proffered command was followed by a request to retire, which was granted. 


\section{CHAPTER VIII.}

Colonel Williams appointed in Morgan's place-Severe duty of Lee's Legion and the corps of Williams-An alarm-Lee interrupted at his breakfast and sent off on duty-Gives his bugler's horse to a countryman-Attacks 'Tarleton's cavalry-Defeats them-No quarter-British Captain Miller saved by Lewis-Lewis reprimanded by Lee, who determines to sacrifice the captain-How he escapes death-Miller writes an account of this to the British army -Effect of his letter.

WE now proceed with Lee's intensely interesting account of an affair immediately preceding Greene's famous passage of the Dan.

Colonel Otho Holland Williams, of Maryland, an accomplished gentleman and experienced soldier, being called to the station, so anxiously, but vainly, pressed on Morgan, accepted it with cheerfulness and diffidence. This last arrangement being finished, Greene put his army in motion, leaving Williams on the ground. The greater the distance between the main body and the light troops, the surer would be Greene's retreat. Williams, therefore, soon after breaking up from Guilford court-house, on the 10th, inclined to the left, for the purpose of throwing himself in front of Lord Cornwallis. This movement was judicious, and had an immediate effect. His lordship, finding a corps of horse and foot 
close in front, whose strength and object were not immediately ascertainable, checked the rapidity of his march to give time for his long extended line to condense.

The enemy persevering in his rapid advance, our rear guard (composed of the legion of Lee) and the British van under Brigadier O'Hara, were in sight during the day. Throughout the night, the corps of Williams held a respectful distance, to thwart, as far as was practicable, nucturnal assault.

The duty, severe in the day, became more so at night; for numerous patrols and strong piquets were necessarily furnished by the light troops, not only for their own safety, but to prevent the enemy from placing himself, by a circuitous march, between Williams and Greene. Such a manœuvre would have been fatal to the American army; and to render it impossible, half of the troops were alternately appropriated every night to duty: so that each man, during the retreat, was entitled to but six hours' repose in forty-eight.

Notwithstanding this privation, the troops were in fine spirits and good health; delighted with their task, and determined to prove themselves worthy the distinction with which they had been honored. At the hour of three, their toils were renewed; for Williams always pressed forward with the utmost despatch in the morning to gain such a distance in front as would secure breakfast to his soldiers, their only meal during this rapid and hazardous retreat.

So fatigued was officer and soldier, and so much more operative is weariness than hunger, that each man, not 
placed on duty, surrendered himself to repose as soon as the night position was taken. Situated as was Williams, no arrangement could been devised, better calculated to effect the great object of his trust, and to secure food once a day to his troops.

The moment Lord Cornwallis found it necessary to change his course and to push for Dix's ferry, he ordered his van to proceed slowly; and separating from it at the head of the main body, which had now arrived at a cross-way leading to the desired route, he quickly gained the great road to Dix's ferry, the course of the American light corps.

In pursuance of this system, Williams made a rapid morning's march; and leaving small patrols of cavalry near the enemy, sent forward the staff to select ground and prepare fires. The officers and dragoons, who had been necessarily kept in sight of the British, upon joining, were hastened in front to a farmhouse near the road, where they enjoyed, although a few hours later, a more comfortable meal. Lieutenant Colonel Carrington, who commanded the dragoons near the enemy's van, reported from time to time, in conformity to custom, by which it appeared, that Cornwallis was moving as usual.

The morning was cold and drizzly; our fires, which had been slow in kindling, were now lively; the meat was on the coals, and the corn cake in the ashes. At this moment, a friendly countryman appeared, riding in haste to our camp, whither he had been directed by the sergeant of one of the horse patrols, with which he fell in on his way. The hurry of his approach, and the tired condition of his meager pony, evinced sincerity of 
heart; while the joy of his countenance declared his participation of interest. Asking for "the general," he was conducted to Colonel Williams, whom he bluntly informed, that Lord Cornwallis, leaving his former route, had got into our road; that one half hour past he left the British army advancing, then only four miles behind; that accidentally discovering it from his field, where he was burning brushwood, he ran home, took the first horse he could find, and hastened to give his friends intelligence, which he deemed important. To attach doubt to the information of an honest looking farmer would have violated all the rules of physiognomy.

Williams always delighted to indulge and comfort his brave troops; and, although he credited the countryman, was unwilling to interrupt their hasty repast. He therefore ordered Lieutenant Colonel Lee to detach from his cavalry, in order to ascertain the correctness of the intelligence. Captain Armstrong, with one section of the horse, was despatched accordingly, with the countryman for his guide.

Soon after their departure, Carrington, still near the enemy, communicated the unusually slow progress of the van guard. Combining this intelligence with that just received, Williams ondered Lieutenant Colonel Lee to strengthen Armstrong, and to take upon himself the command entrusted to that officer. Lieutenant Lewis, with the required addition, atteuded Lee, who despatched one of the dragoons to overtake Armstrong, with orders directing him to move slowly until he should join.

Quickly reaching Armstrong, who had not advanced more than a mile, Lee proceeded, in conformity with the 
advice of the countryman, two miles further; but seeing no enemy, he began to believe that his guide, however well affected, was certainly in a mistake. He determined, therefore, to return to breakfast, and leave Armstrong with three dragoons and the guide to continue on to the spot, where the countryman's information had placed the enemy one hour before.

Armstrong selected the dragoons mounted on the swiftest horses, and was in the act of moving, when the amicable countryman protested against accompanying him, unless furnished with a better horse. While with the whole detachment, he had thought himself safe, and never manifested any unwillingness to proceed; but now, being associated with the most alert of alert dragoons, whose only duty was to look and fly, he considered his danger extreme. This remonstrance, the justice of which could not be resisted, added another reason for crediting the information.

Lee dismounted his bugler, whose horse was given to the countryman; and the bugler was sent back to camp to inform Williams how far the lieutenant colonel had proceeded without seeing any portion of the enemy, and of his intention to return after advancing Armstrong still further in front.

Not doubting that the countryman had seen the British army, but supposing him to be mistaken in the distance, Lee led his detachment into the woods, and retired slowly, in sight of the road. He presumed, that should Armstrong be followed, the enemy would discover the trail of advancing horse in the road, and be deterred from a keen pursuit, which he did not wish to encourage, 
as it might deprive the light troops of their meal; although he was disposed in that event to seize any advantage which might offer. Not many minutes elapsed before a discharge of musketry announced that Armstrong had met the enemy; and shortly after, the clangor of horses in swift speed declared the fast approach of cavalry. Armstrong soon appeared, closely followed by a troop of Tarleton's dragoons.

Lee saw his captain and small party well in front, and hand in hand. For them he felt no apprehensions; but for the safety of his bugler, on the countryman's pony, every feeling of his heart became interested. Being passed unperceived by the pursued and pursuers, Lee continued to proceed in the woods, determined to interpose in time to rescue his bugler, yet wishing to let the enemy take the utmost allowable distance, that they might be deprived of support. Directing one of his lieutenants to halt with the rear file and ascertain whether additional cavalry was following, Lee hastened his progress, and soon saw the enemy's near approach to his defenceless bugler, who was immediately unhorsed, and sabred several times while prostrate on the ground.

Lee was pressing forward to the road in the enemy's rear, when the officer who had been left behind, rejoined with the acceptable information, that no reinforcement was approaching. Gaining the road, the lieutenant colonel rushed forward in quick charge, and fell upon the troop of Tarleton soon after it had reached his bugler.

Captain Miller instantly formed, and fronted his approaching adversary; but his worn-down ponies were as 
ill-calculated to withstand the stout, high-conditioned, active horse opposed to them, as were the intoxicated, inexpert riders unfit to contend with dragoons always sober, and excelling in horsemanship. The enemy was crushed on the first charge : most of them were killed or prostrated, and the residue, with their captain, attempted to escape. They were pursued by lieutenant Lewis, who was commanded by Lee to give no quarters. This sanguinary mandate, so contrary to the American character, proceeded from a view of the bugler, a beardless, unarmed youth, who had vainly implored quarter, and in the agonies of death presented a spectacle resistless in its appeal for vengeance.* Having placed the much wounded, hapless boy in the arms of the stoutest of his dragoons, and directed another soldier to attend them to camp, the lieutenant colonel proceeded in support of Lewis. Soon this officer was met, returning with Captain Miller, and all, save two, of the fugitives.

The British captain was unhurt; but his dragoons were severely cut in the face, neck, and shoulders. Lewis was reprimanded on the spot for disobedience of orders; and Miller, being peremptorily charged with the atrocity perpetrated in his view, was told to prepare for death. The captain, with some show of reason, asserted, that intelligence being his object, it was his wish

* This ill-fated boy was one of the band of music, and exclusively devoted in the field to his horse, used in conveying orders. Too small to wield a sword, he was armed only with one pistol, as was the custom in the legion; that sort of weapon being considered of little import in action : now he had not even his pistol, it being with the countryman mounted on his horse. 
and interest to save the soldier, that he had tried to do so, but his dragoons being intoxicated, all his efforts were ineffectual. He added, that in the terrible slaughter under Lieutenant Colonel Buford, his humanity was experienced, and had been acknowledged by some of the Americans who escaped death on that bloody day.

Lee was somewhat mollified by this rational apology, and was disposed to substitute one of the prisoners; but soon overtaking the speechless, dying youth, whose relation to his supporting comrade of the tragical particulars of his fate, when able to speak, confirmed the former impression of Lee, he returned with unrelenting sternness to his first decision. Descending a long hill, he repeated his determination to sacrifice Miller in the vale through which they were about to pass; and handing him a pencil, desired him to note on paper whatever he might wish to make known to his friends, with an assurance that it should be transmitted to the British general.

At this moment the rear guard communicated, by pistol discharge, the approach of the British van. Miller and his fellow prisoners were hurried on to Colonel Williams, who was at the same time informed of the enemy's advance. Williams put his corps in motion, and forwarded the captured officers and soldiers to headquarters; ignorant of the murder of the bugler, and the determination of Lieutenant Colonel Lee.

Thus Miller escaped the fate to which he had been doomed; in order to convince the British cavalry under Lieutenant Colonel Tarleton, that American blood should no longer be wantonly shed with impunity. Believing himself indebted for his life to the accident just recited, 
Captain Miller took care to represent, by letter, to his friends in the British army what had happened, and his conviction of what would have followed; and never afterwards were such cruelties repeated by the British cavalry acting against the army of Greene.

The dead, eighteen in number, being left on the road where they fell, were buried by order of Lord Cornwallis as he passed. On the part of the American officer no life was lost, except that of the beardless bugler, who died soon after the advance of the enemy was announced. His corpse was necessarily deposited in the woods adjoining the road, with the hope that some humane citizen might find it.

The pursuit was continued with unceasing activity. Williams, retiring in compact order, with the legion of Lee in his rear, held himself ready to strike, whenever an opportunity presented. The skillful enemy never permitted any risk in detail, but preserved his whole force for one decisive struggle. 


\section{CHAPTER IX.}

Lee again interrupted at his breakfast-Narrow escape of Lee and his Legion-near approach of the enemy-Night march-Great alarm of Lee for Greene's safety-He comes on Greene's deserted camp-Greene passes the Dan-Williams and Lee pass the DanEnd of the retreat-Its immense importance-The salvation of the Southern States-General remarks on the retreat.

Having continued on the route to Dix's ferry as far as he deemed advisable, and presuming that General Greene would, on the next day, reach the vicinity of the Dan, Colonel Williams determined to pass to the road on his right, leading to Irwin's ferry, the route of the main body. He communicated this intention to the rear officer, and moved forward with increased celerity, for the purpose of gaining a distant night position, that he might be able to diminish the guards necessary for the security of his corps when close to the enterprising enemy.

Lieutenant Colonel Lee having discovered, from conversation with his guides, that a bye-way in front would lead him into Williams's rear before the close of evening, and save a considerable distance, determined to avail himself of the accommodation. A subaltern's command of dragoons was left to proceed on the route taken by Colonel Williams, with orders to communicate any ex- 
traordinary occurrence to the commandant and to Lieutenant Colonel Lee. The cavalry who met Miller in the morning had lost their breakfast, and Lee's chief object in taking the short course was to avail himself of an abundant farm for the refreshment of his party. As soon as he reached the proposed route, the infantry were hastened forward, with directions to halt at the farm, and prepare for the accommodation of the corps, while the cavalry continued close to the enemy. In due time afterwards, they were drawn off and passed through the woods, leaving in front of the British van the detachment which had been selected to follow the route of the light troops. The obscurity of the narrow road taken by Lee, lulled every suspicion with respect to the enemy, and a few videts only were placed at intermediate points, rather to give notice when the British should pass along, than to guard the legion from surprise. This precaution was most fortunate; for so it happened that Cornwallis having ascertained that Greene had directed his course to Irwin's ferry, determined to avail himself of the nearest route to gain the road of his enemy, and took the path which Lee had selected.

Our horses were unbridled, with abundance of provender before them; the hospitable farmer had liberally bestowed his meal and bacon, and had given the aid of his domestics in hastening the much wished repast. To the surprise and grief of all, the pleasant prospect was instantly marred by the fire of the advanced videts-certain signal of the enemy's approach. Before the farm was a creek, which, in consequence of the late incessant rains, could be passed only by a bridge, not more dis- 
tant from the enemy than from our party. The cavalry being speedily arrayed, moved to support the videts, while the infantry were ordered, in full run, to seize and hold the bridge.

The enemy was equally surprised with ourselves at this unexpected meeting; and the light party in front halted, to report and be directed. This pause was sufficient. The bridge was gained, and soon passed by the corps of Lee. The British followed. The road over the bridge leading through cultivated fields for a mile, the British army was in full view of the troops of Lee as the latter ascended the eminence on whose summit they entered the great road to Irwin's ferry.

Thus escaped a corps, which had been hitherto guarded with unvarying vigilance; whose loss would have been severely felt by the American general, and which had been just exposed to imminent peril from the presumption of certain security. Criminal improvidence! $\mathrm{A}$ soldier is always in danger, when his conviction of security leads him to dispense with the most vigilant precaution.

Cornwallis, at length in Greene's rear, urged his march with redoubled zeal, confident of overtaking his adversary before he could reach the Dan. Adverse efforts to accelerate and to retard, were unceasingly exhibited during the evening; the enemy's van being sometimes so close as to indicate a determination to force the light troops to prepare for defence. Avoiding a measure replete with peril, Williams persevered in his desultory retreat. More than once were the legion of Lee, and the van of O'Hara within musket shot, which pre- 
sented so acceptable an invitation to the marksmen flanking the legion, that they were restrained with difficulty from delivering their fire. This disposition being effectually checked, the demeanor of the hostile troops became so pacific in appearance, that a spectator would have been led to consider them members of the same army. Only when a defile or a water course crossed our route did the enemy exhibit any indication to cut off our rear; in which essays, being always disappointed, their useless efforts were gradually discontinued.

The fall of night excited pleasure, as it promised respite from toil. But illusory was the expectation! for the British general was so eager to fall on Greene, whom he believed within his grasp, that the pursuit was not intermitted. The night was dark, the roads deep, the weather cold, and the air humid. Williams, throwing his horse in front, and the infantry of the legion in the rear, continued his retreat.

About eight in the evening, numerous fires discovered an encampment before us. No pen can describe the heart-rending feelings of our brave and wearied troops. Not a doubt was entertained that the descried camp was Greene's, and our dauntless corps was convinced that the crisis had now arrived when its self-sacrifice could alone give a chance of escape to the main body. With one voice was announced the noble resolution to turn on the foe, and, by dint of desperate courage, so cripple him as to force a discontinuance of pursuit. This heroic spirit, first breathed in whispers, soon gained the ear of Williams, who, alike daring and alike willing to offer up his life for the safety of an army on which the 
hopes of the South rested, would have been foremost in the bold conflict. But his first impressions soon yielded to conclusions drawn from a reference to the date of General Greene's last letter, which demonstrated the mistaken apprehension of the troops. Enjoying the delight inspired by their manly ardor, and commending their devotion to their country, he calmed their disquietude. They shortly reached the camp of fires, and discovered that it was the ground where Greene had halted on the evening of the 11th. Relieved from the dire foreboding, the light corps continued its march until the rear officer made known to the commandant that the enemy had halted. The first convenient spot was occupied for the night; the fires were instantly kindled, the cold and wet, the cares and toils of the day, were soon forgotten in the enjoyment of repose.

About midnight our troops were put in motion, in consequence of the enemy's advance on our piquets, which the British general had been induced to order from knowing that he was within forty miles of the Dan, and that all his hope depended on the exertions of the following day. Animated with the prospect of soon terminating their present labors, the light troops resumed their march with alacrity. The roads continued deep and broken, and were rendered worse by being incrusted with frost: nevertheless, the march was pushed with great expedition. In the forenoon one hour was applied by both commanders to the refreshment of their troops.

About noon Colonel Williams received a letter from General Greene, communicating the delightful tidings of 
his passage over the Dan on the preceding day. The whole corps became renovated in strength and agility; so powerful is the influence of the mind over the body. The great object of their long and faithful labors being so nearly accomplished, a general emulation pervaded all ranks to hasten to the boundary of their cares and perils. The hopes of the enemy were still high, and he rivalled our increased celerity; the van of O'Hara following close on the rear of Lee. About three in the evening we arrrived within fourteen miles of the river; and Colonel Williams, leaving the legion of Lee to wait on the enemy, took the nearest course to Boyd's ferry. Before sunset he gained the river, and was soon transported to the opposite shore.

Lee, at the assigned period, directed his infantry to follow on the route of Williams; and about dark withdrew with his cavalry, the enemy being still in motion. Between the hours of eight and nine, the cavalry reached the river, just as the boats had returned from landing the legion infantry. In obedience to the disposition of Lieutenant Colonel Carrington, quarter master general, who superintended, in person, his arrangements for the transportation of the army, the horses were turned into the stream, while the dragoons, with their arms and equipments, embarked in the boats. Unluckily, some of the horses turned back, and gaining the shore, fled into the woods; and for a time some apprehensions were entertained that they might be lost. They were, however, recovered; and being forced into the river, followed those preceding them. In the last boat, the quarter 
master general attended by Lieutenant Colonel Lee and the rear troop, reached the friendly shore.

In the evening Lord Cornwallis had received the unwelcome news of Greene's safe passage over the Dan; and now relinquishing his expectation of annihilating a second army, and despairing of striking the light corps, so long in his view and always safe, he gave repose to his vainly wearied troops.

Thus ended, on the night of the 14th of February, this long, arduous, and eventful retreat.

No operation during the war more attracted the public attention than did this: not only the toils and dangers encountered by a brave general and his brave army interested the sympathy of the nation, but the safety of the South, hanging on its issue, excited universal concern. The danger of this contingency alarmed the hearts of all, especially the more reflecting, who deemed the integrity of the Uuion essential to American liberty and happiness, and indispensable to our future safety and strength.

Destroy the army of Greene, and the Carolinas with Georgia inevitably became members of the British empire. Virginia, the bulwark of the South, would be converted first into a frontier, then into the theatre of war. Already drained nearly to the bottom, she would be committed into a contest for life with reduced means and broken spirits. All the country south of James river, so convenient to predatory incursions from the southern states, would soon be ground to dust and ashes. Such misery without hope could not be long endured; and reannexation to the mother country, presenting the 
only cure within reach, it would be solicited and obtained. That part of the state north of James river, and west of the Blue ridge, must continue united; and so far as its ability permitted, would be found a daring and destructive foe. But in this desperate condition of affairs, with the enemy's uncontrolled maritime superiority, and the facile admission into the bosom of the country, presented by its fine rivers, its resistance could not be of long duration. The stoutest heart trembled lest the Potomac should become the boundary of British dominions on the east of the Blue ridge.

Happily for these states, a soldier of consummate talents guided the destiny of the South.

Cordially supported and truly beloved by the august personage at the head of the American armies, the bosom of Greene, gratefully reciprocating feelings so honorable to his character, never was assailed by those degrading passions, envy and malevolence, which too often disturb the harmony of associate leaders, and generate deep disasters to the common cause.

The glory of Washington, next to the safety of his country, was the prime object of his wishes. Pure and tranquil from the consciousness of just intentions, the undisturbed energy of his mind was wholly devoted to the effectual accomplishment of the high trust reposed in him.

The difficulty of retreat from South Carolina with an inferior army, and that army acting necessarily in two divisions at a great distance from each other,-the state of North Carolina, stored with faithful abettors of the royal cause, who waited with solicitude for a fit oppor- 
tunity to demonstrate their unshaken loyalty,--presented in themselves impediments great and difficult. When we add the comfortless condition of our troops in point of clothing,* the rigor of the season, the inclemency of the weather, our short stock of ammunition, and shorter stock of provisions, - and contrast it with the comfortable raiment and ample equipment of the enemy, inured to service, habituated to daring enterprises, the very troops which had taken Lincoln and destroyed Gates, rendered capable of the most rapid movements by their voluntary sacrifice of baggage, provisions, and liquor, and conducted by a general always to be dreaded,-we have abundant cause to honor the soldier whose mental resources smoothed every difficulty, and ultimately made good a retreat of two hundred and thirty miles, (unaided, except occasionally by small corps of friendly militia) without the loss of either troops or stores. Nor can we hesitate in acknowledging, that the scene just closed, presented satisfactory displays of that masterly genius,

* The shoes were generally worn out, the body clothes much tattered, and not more than a blanket for four men. The light corps was rather better off; but among its officers there was not a blanket for every three : so that among those whose hour admitted rest, it was an established rule, that at every fire, one should, in routine, keep upon his legs to preserve the fire in vigor. The tents were never used by the corps under Williams during the retreat. The heat of the fires was the only protection from rain, and sometimes snow : it kept the circumjacent ground and air dry, while imparting warmth to the body.

Provisions were not to be found in abundance, so swift was our progress. The single meal allowed us was always scanty, though good in quality and very nutritious, being bacon and corn meal. 
which, in the sequel, unfolded itself with such utility and splendor.

The British army have also a clear title to praise. More comfortably clad, the soldier was better able to bear the extremes of the season: in every other respect he equalled his enemy-bearing incessant toil, courting danger, and submitting to privation of necessary food with alacrity; exhibiting, upon all occasions, unquestionable evidence of fidelity, zeal, and courage, in seconding the hardy enterprise of his admired leader.

General Greene, reviewing his army, at length safely enjoying wholesome and abundant supplies of food in the rich and friendly county of Halifax, bestowed upon all his commendations; distinguishing by his marked approbation, Colonel Williams, and Lieutenant Colonel Carrington quarter master general. 


\section{H A P T E R X.}

Cornwallis's proclamation-Its effect-Greene determines to harass him and prevent his gaining recruits in North Carolina-Pickens and Lee ordered to recross the Dan, on this service-Greene passes a night in their camp-They pursue Tarleton-His force-Come upon his deserted qnarters-Lee and Pickens assume the character of loyalist reinforcements-Success of the stratagem-They hear of Pyle's detachment of royalists-They entrap Pyle's detachment and are about to capture it, when an accident brings on an action and Pyle's men are sacrificed-Pickens and Lee pursue 'Tarleton's regiment-Are joined by Colonel Preston and his Virginia militiaOrder of advance-Tarleton recalled by Cornwallis-His narrow escape from Lee and Pickens.

CoRnwalims established his headquarters at Hillsborough, and forthwith issued a proclamation to the inhabitants of North Carolina inviting them to join the royal standard; and promising pardon, protection, and so forth, as usual with the British commanders. Many of the inhabitants availed themselves of his offers. The royalists every where were preparing to rise, while the well affected to the cause of America, seeing that Greene had been driven out of the state, despaired of protection, and began to look for safety in submission.

But Greene, although driven out of the state, had by no means abandoned it.* Determining to risk his army

* Lee's Memoirs of the War in the Southern Department of the United States. 
again in North Carolina,-to rouse the drooping spirits of his friends, and to check the audacity of his foes,the legion of Lee, strengthened by two companies of the veterans of Maryland under Captain Oldham, with the corps of South Carolina militia under Brigadier Pickens, was ordered, in the morning of the 18th, to repass the Dan. This was readily performed; all the boats heretofore collected being still held together by Carrington for the use of the army.

Pickens and Lee were commanded to gain the front of Cornwallis, to place themselves as close to him as safety would permit, to interrupt his communication with the country, to repress the meditated rising of the loyalists, and, at all events, to intercept any party of them which might attempt to join the enemy.

These officers lost no time in advancing to the theatre of operations ; and having in the course of the march provided capable guides, sat down that evening in a covert position, short of the great road leading from the Haw river to Hillsborough, and detached exploring parties of cavalry on the roads towards Hillsborough and towards the Haw. In the course of the evening, Greene, never avoiding toil or danger, with a small escort of Washington's cavalry left his army, and overtook the advanced corps in its secret position. He continued with it during the night, and renewed to the two commandants explanations of his plan and object. He communicated his intention of repassing the Dan with the army in a few days, directing his route towards the upper country; too remote, as he remarked, from the advanced corps to afford the smallest protection; urged cordial concert, 
pressed in fervid terms the necessity of unceasing vigilance, and the most cautious cireumspection.

Before dawn the officer, who had been despatched towards the Haw, returned with intelligence, that on the preceding day Lieutenant Colonel Tarleton had passed up that route from Hillsborough with horse, foot, and artillery; their number unascertained; destined, as was presumed, to pass the Haw river, with the view of hastening the embodying of the loyalists, and of protecting them on their march to Hillsborough.

The wisdom of the measure, adopted by Greene, was now shown, as already an important object presented itself to the detached corps. Greene having set out on his return to camp, Pickens and Lee advanced; first sending reconnoitring parties in their front, with orders to conceal themselves in sight of the road, to watch passing occurrences, and to report from time to time the result of their observations. The main body moving obliquely to their right through an unsettled region, they encamped within three miles of the great road, with the Haw on their right, about seven miles distant. Here they were joined by the light parties sent out in the morning, and by the officer who had the day before been detached towards Hillsborough. The first reported that every thing was still on the road, and that they had not seen a single person, except a well grown boy, during the day, whom they had brought along with them agreeable to orders. From this lad we discovered that Tarleton had not passed the river yesterday, but would do it on the next morning.

The officer who had approached Hillsborough found 
all quiet in that quarter, and neither saw nor heard any thing indicating a movement on the part of the enemy. Resting for the night, the corps proceeded after breakfast the next day, waiting until then to give time for the exploring parties to renew their efforts in obtaining more precise intelligence.

Approaching the road, it was met by a dragoon bringing information that the British detachment had passed. the Haw. This being ascertained, Pickens and Lee gained the great road, and followed on the enemy's route. Guides became unnecessary now ; for the British detachment had plundered all the houses on the road, known, as they were, to be the property of patriots, and symbols of devastation marked their steps. The men having all fled, none but women could be seen.

From them the American commandants learned, that the loyalists between the Haw and Deep rivers were certainly embodying, and that the British detachment would not advance far on the other side of the river, it being commonly said among the soldiers, that they should return in a few days. By what could be gathered from report, and judging by the time of passing any one house, it appeared that most of the cavalry, two light brass pieces, and four hundred infantry, composed the detachment. Sending again a small party of dragoons down the road, to discover whether any second body of troops were moving from Hillsborough, Pickens and Lee continued on to the Haw, which they passed without delay, hearing that Lieutenant Colonel Tarleton was encamped four miles in front. At this moment the officer sent 
down the road, rejoined, communicating that there was no prospect of interruption from that quarter.

Soon after we had crossed the river, which was fordable, a countryman was discovered by the cavalry in front; and being overtaken, was sent to the commandants. From him it was ascertained, that Lieutenant Colonel Tarleton, as had been reported, commanded the party, and that he was encamped within three miles of us about noon; that his horses were unsaddled, and that appearances indicated his confidence of security. With respect to his strength, the countryman's information rated it the same as it was before understood to be. This being correct, Tarleton had the advantage in number of cavalry, but was inferior in quality: he had two light pieces, the Americans none: he was numerically inferior in infantry; but his troops were all tried regulars, while half of our infantry were militia, though of the best sort.

A disposition for attack was immediately made. The infantry of the legion led by Lieutenant Colonel Lee, forming the centre, moved directly towards the enemy, with the cavalry in column under Major Rudulph, upon its right; and the militia riflemen, conducted by Brigadier Pickens, on its left. Oldham, with the two Maryland companies, composed the reserve. Presuming a surprise probable, the march was concealed by keeping through woods, having faithful guides with each division. In this event Major Rudulph had orders to charge in full gallop, supported by Oldham with the reserve; while the legion infantry, covered on its left by the riflemen, in whatever state the enemy might be found, was destined 
to carry the field pieces with fixed bayonets. Should he be apprised of our advance, and consequently prepared for our reception, Oldham, with his Marylanders, was ordered to take the place of the cavalry on the right of the legion infantry, and Rudulph, with the dragoons, to stand in reserve.

Thus arrayed, the divisions proceeded to their designated points, every precaution having been adopted to prevent diseovery. The movement was conducted with the utmost precision and correspondency. When arriving within a few hundred yards of the expected theatre of glory, the farm and house was seen, but no enemy. The van of the horse galloping to the house, found and brought off two of the enemy's staff, who had been delayed in settling for the subsistence of the detachment; and hearing from the family that Lieutenant Colonel Tarleton would not advance above six miles further, Pickens and Lee instantly proceeded towards him, hoping that fortune would be more propitious upon the next occasion.

Thus did the bright prospect of the morning vanish, exciting of itself deep chagrin; rendered more galling, finding that Tarleton, believing hinself perfectly secure, had been unusually remiss, and would have been caught in a condition out of which neither skill nor courage could have extricated him.

To give success, if possible, to this second attempt, it was determined to pass as a reinforcement sent from Hillsborough to Lieutenant Colonel Tarleton; and the two prisoners being placed in the centre of the cavalry, were charged to conduct themselves so as to give cur- 
rency to the deception, in default of which, the sergeant having the care of them, was directed to put them to death instantly. The legion taking the lead, with the horse in front, Lieutenant Colonel Lee put himself at its head, to direct operations both delicate and important. This stratagem could not fail in imposing on the country people, however well acquainted they might be with the appearance of British troops, so far as respected the legion, inasmuch as both cavalry and infantry were dressed in short green coats, with other distinctions exactly resembling some of the enemy's light corps.

Lee's van officer, preceding him a few hundred yards only, was met by two well-mounted young countrymen, who being accosted in the assumed character, promptly answered, that they were rejoiced in meeting us, having been sent forward by Colonel Pyle for the purpose of ascertaining Tarleton's camp, to whom the colonel was repairing with four hundred loyalists. These youths were immediately sent to Lieutenant Colonel Lee, but were preceded by a dragoon, with the information imparted. Immediately upon the arrival of the dragoon, Lee despatched his adjutant with the intelligence to Brigadier Pickens, requesting him to place his riflemen (easily to be distinguished by the green twigs in their hats, the customary emblem of our militia in the South) on the left flank, out of sight, which was readily to be done, as we were then in a thick wood; at the same time to assure him that Lee was determined, in conformity with the concerted plan, to make an attempt with the legion of turning the occurrence to advantage. The prisoners were ulso reminded, as was the sergeant having them in care, 
of the past order. This communication was scarcely finished, before the two dragoons rode up with the two countrymen, who were received with much apparent cordiality; Lee attentively listening with seeming satisfaction to their annunciation of the laudable spirit which had actuated Colonel Pyle and his associates, and which they asserted was rapidly spreading through the country.

Finding them completely deceived, (for they not only believed the troops they saw to be British, but overlooking what had been told them, took them to be Tarleton's, addressing the commandant as that officer, ) Lee sent one of them back with the two dragoons to his van, thence to proceed to Colonel Pyle with Lieutenant Col. Tarleton's gratulations, and his request that he would be so good as to draw out on the margin of the road, so as to give convenient room for his much fatigued troops to pass without delay to their night position, while the other was detained to accompany the supposed Tarleton. Orders were at the same time despatched to the van offcer to halt as soon as he got in sight of the loyalists.

As Lee approached his officer, who had halted, highly gratified with the propitious prospect, and listening to the overflowings of respect and devotion, falling incessantly from the lips of his young attendant, his comrade, who had been sent to Colonel Pyle, returned with his expected compliance, announced in most respectful terms.

The column of horse now became complete by union with the van, and Colonel Pyle was in sight on the right of the road, drawn up as suggested, with his left to the 
advancing column.* This last circumstance was fortunate, as Lieutenant Colonel Lee had concluded to make known to the colonel his real character as soon as he should confront him, with a solemn assurance of his and his associates' perfect exemption from injury, with the choice of returning to their homes, or of taking a more generous part, by uniting with the defenders of their common country against the common foe. By Pyle's lucky occupation of the right side of the road, it became necessary for Lee to pass along the whole line of the loyalists before he could reach their colonel, and thus to place his column of horse in the most eligible situation for any vicissitude.

They were mounted like our militia, fitted like them to move on horseback, and to fight dismounted. Their guns (rifles and fowling pieces) were on their shoulders, the muzzles consequently in an opposite direction to the cavalry. In the event of discovery, they must have changed the direction before they could fire, a motion not to be performed with a body of dragoons close in with their horses' heads, and their swords drawn.

The danger of this rare expedient was by no means so great as it appears to be on first view.

Lee passed along the line at the head of the column with a smiling countenance, dropping, occasionally, ex-

* Had Pyle accidentally arrayed upon the left of the road, he would have been found on the right of his regiment, the flank first reached by the column of the horse. Some pretext must have been adopted to have moved on to the other flank, so as to place the horse in the requisite posture, before Lieutenant Colonel Lee could make the desired communication; therefore it was fortunate that he should have chosen the side of the road on which he was found posted. 
pressions complimentary to the good looks and commendable conduct of his loyal friends. At length he reached Colonel Pyle, when the customary civilities were promptly interchangcd. Grasping Pyle by the hand, Lee was in the act of consummating his plan, when the enemy's left, discovering Pickens' militia, not sufficiently concealed, began to fire upon the rear of the cavalry commanded by Captain Eggleston. This officer instantly turned upon the foe, as did immediately after the whole column. The conflict was quickly decided, and bloody on one side only. Ninety of the royalists were killed, and most of the survivors wounded. Dispersing in every direction, not being pursued, they escaped. During this sudden rencontre, in some parts of the line the cry of mercy was heard, coupled with assurance of being our best friends; but no expostulation could be admitted in a conjuncture so critical. Humanity even forbade it, as its first injunction is to take care of your own: and our safety was not compatible with that of the supplicants, until disabled to offend. Pyle, falling under many wounds, was left on the field as dying, and yet he survived. We lost not a man, and only one horse. The object so sedulously pressed was thus a second time baffled. Tarletón, within a mile, more fatally secure, if possible, than before, escaped the impending blow ; when to get at him a measure had been hazarded, not warranted on ordinary occasions, but now enforced by the double motive of sparing the lives of deluded fellow citizens, and humbling effectually the British partisan and his active corps, whose destruction in the relative condition of the two armies would have probably led to the 
termination of the war in the South. Lord Cornwallis was at the head of a brave enterprising force, but small in number; too small, when reduced by the loss of Tarleton's corps, to have made head against Greene, when assisted, as the American general must have been, by the surrounding country, animated to their best exertions by such signal success.

The discomfiture of Pyle being soon effected, Lee ordered the cavalry to resume its march, and to take post so as to arrest any sudden interference on the part of Lieutenant Colonel Tarleton, who must have heard the enemy's fire, and might probably interpose with the expectation of controlling the event of the confiict.

Brigadier Pickens, following quickly, soon reached the van of the legion, whose cavalry had approached in view of Tarleton's camp. Then were seen incontestable evidences of the embarrassing confusion which an unexpected enemy never fails to produce, even amongst the best disciplined troops,--demonstrating, without shadow of doubt, our certain success, had Pyle and his party been, as they ought to have been, at their own firesides. The sun was setting; and for some moments Pickens and Lee hesitated whether immediate action was not, even at that hour, the eligible course. The troops were fatigued by their long march, increased by preparation for two combats and the rencontre with Pyle. This consideration, combined with the close approach of night, determined them to postpone battle until the morning. Moving to their left, they placed themselves between the British and the upper country, on the great road leading through Tarleton's camp to Hillsborough. The 
advanced sentinels and the patrols were stationed every where in sight of each other.

Here they heard from some countrymen, who, abandoning their houses on the enemy's advance, had fallen in with Pickens, that a small party of militia had collected for mutual safety a few miles in the rear. A dragoon, attended by one of the informants, was immediately despatched with a letter to the officer, requesting him to hasten to camp; more for the purpose of procuring accurate information of the ground expected soon to be the theatre of action, and of furnishing faithful intelligent guides, than from any expectation of aid in battle. It so happened, that with the militia company was found Colonel Preston, of Montgomery county in Virginia, just arrived at the head of three hundred hardy mountaineers, who, hearing of Greene's retreat, had voluntarily hastened to his assistance,-alike ignorant until that hour of the general's having recrossed the Dan, and of Tarleton's corps being but a few miles in front.

The wisdom of the measure so speedily adopted by the commander in the South, after securing his retreat, was again now happily illustrated. It not only produced the annihilation of the first body of loyalists which had embodied and armed, but probably saved from destruction a detachment of brave men, induced by love of country, to seek and to succor their hard pressed friends. Colonel Preston accompanied the dragoons to camp, followed by his battalion of riflemen. Although Pickens and Lee were before determined to engage, such an opportune, unlooked for auxiliary force, could not 9 
but excite new spirits in their troops, always proudly conscious of self-ability. Preston, his officers and soldiers, spent their first hour in gazing at the corps. They were much gratified with the orderly appearance it universally exhibited, and particularly delighted with the cheering looks of the dragoons and the high condition of their stout horses.

Our upper militia were never alarmed in meeting with equal numbers of British infantry. Selecting their own ground (which being mounted they could readily do) before they would engage, they considered themselves their equal; but they entertained dreadful apprehensions of the sabre of the cavalry, particularly when associated with the name of Tarleton, who had, on many occasions, used it with destructive effect. From this source was derived the satisfaction expressed on reviewing the legion horse. They became convinced that no equal number of dragoons ought to excite the smallest apprehensions on our part, and they were assured that the British cavalry was not only inferior in their horses, but very much so in horsemanship. Thoroughly satisfied, these welcome auxiliaries retired to their post, responding with ardor the general wish to be led to battle with the dawn of day. Every arrangement being made to meet the approaching conflict, the troops assumed the disposition in which they were to fight, and lay down to rest.

From the intelligence procured, it was ascertained that the field in which the British were encamped, had three or four wood dwelling houses on the road near its centre, and was sufficiently capacious to have admitted conveniently the major part of the respective combatants 
to close action. The legion infantry, led by Lieutenant Colonel Lee, marched along the road, for the purpose as before, of attending specially to the enemy's artillery, of which it has been mentioned we were destitute. Oldham, with his Marylanders, advanced on its right, parallel with Lee; and on his right, in a wood skirting the field, Brigadier Pickens moved, having under him some of the same soldiers who had so nobly supported Howard's right at the Cowpens. Colonel Preston covered Lee's left, having also the advantage of a copse of wood bordering the field in that direction, and being completely secured on his flank by a very extensive mill pond. The cavalry were formed in reserve, the head of the column pointing to the interval between Oldham and Pickens, where the field could be entered out of the fire from the houses, should Tarleton, as was apprehended, occupy them with musketry. Rudulph, who commanded the horse, was directed to fly to the aid of any portion of the troops hard pressed, as well as to be ready to improve our, and to limit their, victory. Between the hours of two and three in the morning, concurring intelligence was received from the piquets and patrols, announcing that the enemy was in motion, and soon afterwards that he was retiring.

The pickets being assembled by the officer of the day, were ordered to advance, while the main body, hastening to arms, followed with celerity. Anxious to know the cause of this sudden and unexpected movement, an officer was directed to call at the house lately occupied by the enemy, for the purpose of inquiry. He reported that Lord Cornwallis, having been apprised of the ad- 
vance of Pickens and Lee, hastened his orders to Lieutenant Colonel Tarleton, communicating the information he had received, and requiring him to repass the Haw instantly, which order the lieutenant colonel very reluctantly obeyed. He further learned that Tarleton and his officers were in high spirits, had enjoyed an abundant. supper together, and were anxiously wishing for the return of light, determined to take complete revenge for the loss of Pyle; and, assured of victory, delighted themselves with the prospect of mounting, in the course of the day, the chosen horses of the legion. So solicitous Lord Cornwallis appears to have been, that he despatched three successive couriers, all of whom arrived; the last two just as the British corps was ready to move. There were three contiguous passages of the Haw. The nearest within four miles, to be passed in a boat, which, from the size of the flat kept at the ferry and the narrowness of the river would not have been very inconvenient; the infantry and artillery might have been thrown over before daylight, and the cavalry would have readily swam across. One mile below was another ferry, alike commodious; and seven miles lower down was a ford, the same which both corps had used the day before. The legion, accustomed to night expeditions, had been in the habit of using pine torches for flambeaux. Supplied with this, though the morning was dark, the enemy's trail was distinctly discovered whenever a divergency took place in his route. He first took the road leading to the upper ferry, the direct route to Hillsborough; but it being always presumed that he would avail himself of the ford, though out of his way, the 
van officer took care occasionally to examine, by the help of his pine knots, and soon ascertained that after passing some small distance on that road, he crossed to the second route. Here repeating his feint, he at length turned to the road leading to the ford.

The diligence of the leading officer saved to the main body loss of ground; as the enemy's stratagem was detected before we reached the points of their separation from each road. As the day broke, the American troops, pursuing with zeal, had reached within two miles of the ford. The cavalry now taking the front, supported by the riflemen, (all mounted) were ordered to press upon the enemy, and hold him back until the infantry could get up. Before sunrise they gained the enemy's rear, descending the hill to the river, over which the main body, having just passed, was placed on a height commanding the ford, for the protection of the rear guard. Too near to be struck at without rashly exposing the troops, it was omitted; much as it was desired to gain some evidence of our triumphant pursuit. At first Pickens and Lee determined, by a quick retrograde, to pass at the ferry above, and to throw themselves in Tarleton's rear.

This was effectible, in case he loitered only one hour on the banks of the Haw, a very probable event. But there was cause to apprehend, from the solicitude displayed by the British general to bring him safely back, that he would send a reinforcement to meet him. In this incertitude desire to give rest to the much fatigued troops prevailed; and, keeping up the western margin of the Haw, the corps halted in the first settlement capable of supplying the necessary subsistence. Thus 
closed twenty-four hours of very active service; its chief object uneffected, and a secondary one completely executed, which produced a very favorable result, by repressing thoroughly the loyal spirit just beginning to burst forth. Fortune, which sways so imperiously the affairs of war, demonstrated throughout the operation its supreme control. Nothing was omitted on the part of the Americans to give to the expedition the desired termination; but the very bright prospects which for a time presented themselves, were suddenly overcast, - the capricious goddess gave us Pyle and saved Tarleton. 


\section{CHAPTER XI.}

General Greene recrosses the Dan-Cornwallis leaves Hillsborough -Williams, Pickens, and Lee, detached to harass Cornwallis--They encounter and baffle Colonel Webster-Encounter with Colonel Webster near Wetzel's mill-His extraordinary escape from Lee's sharp-shooters.

General. Greene, in pursuance of his plan, passed the Dan on the $23 \mathrm{~d}$, strengthened in a small degree by the corps of militia under Stevens, and took a direction towards the head waters of the Haw river. He was highly gratified by the success of his advanced troops, officially communicated to him after he had entered North Carolina; and was pleased to estimate the destruction of Pyle and his loyalists as more advantageous in its effects than would have been a victory over Lieutenant Colonel Tarleton.

Soon after Tarleton returned to Hillsborough, the British general quitted his position,-moving with his whole force to the country from which Tarleton had been just chased, for the purpose of giving complete protection to his numerous friends inhabiting the district between the Haw and Deep rivers, whose danger in attempting to join him while so distantly situated, had lately been fatally exemplified. As soon as this movement on the part of his lordship was known to 
General Greene, he again resorted to his former expedient, of placing a strong light corps between him and the enemy.

Colonel Williams was of course entrusted with its direction, who, moving towards his lordship, directed Pickens and Lee, a part of his establishment, to join him. Colonel Preston, still continuing with Pickens, now made a part of Williams's force. The return of Greene to North Carolina, and the destruction of Colonel Pyle's loyalists, baffled the hopes so long entertained by the British general, and fast realizing after his possession of Hillsborough; where, in the course of one day seven independent companies of loyalists were raised. Lord Cornwallis's project of filling up his ranks with the youth of North Carolina, which he pressed by every means in his power, although suspended by the late event, was not abandoned. Determined to effect it, he had, as we have seen, left Hillsborough, and placed himself among his friends, whose spirits he wished to revive by some decisive success.

Encamped upon the Almance, he held himself ready to seize any opportunity which might be presented, and heard with pleasure of the approach of our light corps under Colonel Williams. This officer was his first object; the next was to force Greene to battle, which he believed would be risked by the American general to save his light troops. In the opinion of many, General Greene committed himself to much hazard in his newly adopted system. It was asked, why not continue in his safe position on the north of the Dan until, receiving all his expected succor, he could pass into North 
Carolina, seeking, instead of avoiding, his enemy. This safe and agreeable course was relinquished from necessity.

Greene, penetrating Cornwallis's views, foresaw their certain success, if he remained long out of the state, waiting for reinforcements himself. $\mathrm{He}$ discerned the probability, that his enemy would acquire a greater proportionate strength: with the essential difference, that what we obtained would be mostly militia, a fluctuating force; whereas, that gained by the enemy would stand to him throughout the contest.

To arrest the progress of this scheme, pursued with pertinacity by the British general, it was necessary again to risk himself, his army, and the South. He therefore passed the Dan as soon as it was in his power; depending on the resources of his fertile mind, and the tried skill and courage of his faithful, though inferior, army.

Crossing the Haw, near its source, the American general established himself between Troublesome creek and Reedy fork. And changing his position every day, sometimes approaching Colonel Williams, and then falling back upon the Troublesome, he held Cornwallis in perfect ignorance of his position, and stopped the possibility of sudden interruption. Showing himself in so many different quarters, he considerably augmented the fears of the loyalists, who had not yet recovered from the consternation produced by the slaughter of their associates. Williams pursued the same desultory game, preserving correspondency in his movements with those of Greene. 
As yet Lord Cornwallis had not been able to find any opportunity to execute his purpose. Williams, more and more satisfied of his safety from his superiority in the quality of his cavalry, and wishing to take a distance whence he could conveniently interrupt the British parties while collecting provisions and forage, placed himself a few miles on the east side of Reedy fork, having the Almance creek between him and the enemy. Lord Cornwallis well knew the superiority of our horse; feeling it daily in the counteraction of his efforts to obtain intelligence, so important in military operations. Indisposed to such a near neighborhood with us, he moved from his camp at three o'clock on the 6th of March, and passing the Almance, pushed forward under the cover of a heavy fog, with the expectation of beating up Williams's quarters.

The left of the light troops were composed of militia, who had lately joined under Colonel Clarke, one of the the heroes of King's Mountain, relieving Brigadier Pickens and the corps who had so faithfully adhered to General Greene during the trying scenes just passed. Clarke's militia were part of the conquerors of Ferguson; better suited for the field of battle than for the security of camp. In this quarter, through some remissness in the guards, and concealed by the fog, Lieutenant Colonel Webster, commanding the British van, approached close before he was discovered.

The alertness of the light troops soon recovered the momentary disadvantage ; and the legion of Lee advancing to support Clarke, the enemy's van was held back, until Colonel Williams, undisturbed, commenced his re- 
treat, directing the two corps above mentioned to cover his rear. Having crossed the Reedy fork, Williams made a disposition, with the view of opposing the enemy's passage. Clarke, following Williams, joined on the opposite bank, - the infantry of the legion proceeding in the rear of Clarke, followed by the cavalry, which corps continued close to the enemy's advancing van.

During this movement Webster made several efforts to bring the rear guard to action, having under him the British cavalry. All his endeavors were successively counteracted by the celerity and precision with which the legion horse manouvred; establishing evidently in the face of the enemy their decided superiority.*

As soon as Lee was apprised of the rear infantry's passage over the river, he retired by troops from before Webster in full gallop; and reaching Reedy fork, soon united with Colonel Williams, unmolested. There being convenient fords over the creek, above and below, after Williams had safely brought over his corps, he determined no longer to continue in his position. Resuming retreat, he left the legion supported by Colonel Clarke, with orders to retard the enemy as long as it was practicable, without hazarding serious injury.

Lee, having detached a company of Preston's militia * No country in the world affords better riders than the United States, especially the states south of Pennsylvania. The boys from seven years of age begin to mount horses, riding without saddle. and often, in the fields, when sent for a horse, without bridle. They go to mill on horseback, and perform all the other small domestic services mounted. Thus they become so completely versed in the art of riding by the time they reach puberty, as to equal the most expert horsemen any where. 
to guard the pass at Wetzell's mill, a little distance upon his left, drew up his infantry in one line, with its right on the road, and its front parallel with the creek; while the riflemen under Colonels Clarke and Preston, occupied a copse of heavy woods on the right of the road, with its left resting upon the right of the legion infantry.

The horse formed a second line in a field well situated to curb the progress of the British cavalry, should it press upon the first line when retiring, and to protect the horses of the militia, tied at some distance back, agreeably to usage. On the first appearance of the enemy, Colonel Williams despatched a courier to Greene, communicating what had passed, and advising him of the course he should pursue after crossing the Reedy fork. Unwilling to approximate Greene, this officer moved slowly, waiting the disclosure of the enemy's intention. Should he halt on the opposite side of the creek, Colonel Williams would take his night position within a few miles of Wetzell's mill, giving time to the troops to prepare food before dark; but should the enemy advance to the hither side, he would necessarily continue his retreat, however much opposed to his wishes.

This state of suspense lasted but a little while. The British van appeared; and after a halt for a few minutes on the opposite bank, descended the hill approaching the water, where, receiving a heavy fire of musketry and rifles, it fell back, and quickly reascending, was rallied on the margin of the bank.

Here a field officer rode up, and in a loud voice addressing his soldiers, he rushed down the hill at their head, our fire pouring upon him, and plunged into the 
water. In the woods occupied by the riflemen, stood an old log school-house, a little to the right of the ford. The mud stuffed between the logs had mostly fallen out, and the apertures admitted the use of rifles with ease.

In this house twenty-five select marksmen, of King's Mountain militia, were posted by Lee, with orders to forego taking any part in the general resistance, but to hold themselves in reserve for particular objects.

The leading officer plunging in the water, attracted general notice; and the school-house party, recollecting its order, singled him out as their mark. The stream being deep, and the bottom rugged, he advanced slowly; his soldiers on each side of him, and apparently some of them holding his stirrup leathers. This select party discharged their rifles at him, one by one, each man sure of knocking him over; and having reloaded, eight or nine of them emptied their guns a second time at the same object.* Strange to tell, though in a condition so perilous, himself and horse were untouched; and having crossed the creek, he soon formed his troops, and advanced upon us.

The moment that the head of his column got under cover of our banks, Lee directed the line to retire from

* The twenty-five riflemen were selected from their superior excellence as marksmen. It was no uncommon amusement among them to put an apple on the point of a ramrod, and holding it in the hand with the arm extended, to permit their comrades, known to be expert, to fire at it; when many balls would pass through the apple; and yet Iieutenant Colonel Webster, mounted upon a stout horse, in point blank shot, slowly moving through a deep water course, was singled out by this party, who fired, seriatim, thirty.two or three times at him, and neither struck hirn nor his horse. 
its flanks, and gain the rear of the cavalry. In the skirmish which ensued in our centre, after some of the enemy ascended the bank, three or four prisoners fell into our hands. The enemy's column being now formed, soon dislodged our centre; and pushing Lee, came in front of the cavalry. Here it paused, until the British horse, which followed the infantry, passed the creek and took post on the enemy's right, - the nearest point to the road, which we must necessarily take. This attitude indicated a decision to interrupt our retreat; at all events to cut off our rear.

Lee ordered Rudulph to incline in an oblique direction to his left; and, gaining the road, to wait the expected charge. Tarleton advanced with his cavalry, followed by Webster. The legion infantry, close in the rear of the riflemen, had now entered the road, considerably advanced towards Colonel Williams, still waiting in his position first taken for night quarters, and afterwards held to protect the rear guard. Rudulph, with the cavalry, was drawn off, moving slowly, with orders to turn upon the British horse if they should risk a charge.

It was now late in the evening, and nothing more was attempted. The British halted on the ground selected by Williams for our use, which he had abandoned. Having proceeded some miles further, he encamped on the northeast side of a range of hills covered with wood, some distance from the road: thus our fires were concealed from view, while the margin of the road and every avenue to our camp was vigilantly guarded.

General Greene, as soon as he was advised in the morning of the enemy's advance, retired and passed the Haw; 
repeating, in his answer, his order to Colonel Williams to avoid action, which he well knew was very practicable, unless our cavalry should meet with disaster. As soon as all appearance of further contest ceased, the prisoners, as was customary, were brought to the commandant; who, among other inquiries, asked, what officer led the enemy into the creek, and crossed with the leading section of the column? He was told, that it was Lieutenant Colonel Webster; and that he had passed unhurt.

Inscrutable are the ways of Providence. That superior soldier, whose life was in such imminent danger, was now safely shielded, though doomed to fall in a very few days. 


\section{CHAPTER XII.}

Greene's army reinforced-Lee harasses Cornwallis-Attempts to cut off an escort with baggage-Adventures of a night-Lost in the woods-Cornwallis's commentary-Cornwallis's approach towards Guilford Court-house-Lee's encounter with Tarleton's cavalry-General Greene prepares for battle with Cornwallis.

CoRnwallis was convinced that he could not bring Greene to an engagement until he should have received his expected reinforcements. In a few days these reinforcements began to arrive at Greene's headquarters, the Iron Works on Troublesome Creek. New levies under Colonel Greene, militia frum Virginia, under Bri. gadier Lawson, came in, and soon afterwards the North Carolina force under Brigadiers Butler and Eaton, bringing up the whole force to four thousand, of whom sixteen hundred were continentals.

Lee with his legion, and some Virginia militia, still hovered round the enemy.

The American dragoons, far superior in the ability of their horses, stuck so close to the British camp as to render their intercourse with the country very difficult, and subjected the British general to many inconveniences, besides interrupting his acquirement of intelligence. 
No equal party of the enemy's horse would dare to encounter them; and if a superior force approached, the fleetness of their horses mocked pursuit. Feeling his privations daily, Lord Cornwallis, leaving his baggage to follow, made a sudden movement late in the evening from Bell's mill towards New Garden, a Quaker settlement, abounding with forage and provisions. Some of the small parties of the legion horse, traversing in every quarter, one of them approached Bell's mill and found it abandoned. When informed by the inhabitants that the baggage had but lately proceeded under a very small escort, the officer commanding the horse determined to trace secretly the progress of its march. It so happened, that early in the night the escort with the whole baggage mistook the road, proceeding directly on, instead of turning towards New Garden. Fortunately the vigilant officer discovered this error, and having ascertained the fact beyond doubt, he despatched a courier to Lieutenant Colonel Lee with the information, attended by two guides well acquainted with the route taken by the British army, that taken by the escort, and the intermediate cross-roads. The intelligence reached Lee about eleven o'clock, (later than was expected,) as he had, from the advance of the enemy, taken a more distant position. Instantly the legion horse, with two companies of infantry mounted behind two of the troops, were put in motion. Lieutenant Colonel Lee, taking the guides sent to him, advanced with the certain expectation of falling in with the lost escort. The night was extremely dark, and the country covered with woods; but the guides were faithful, intelligent, and intimately versed in all the 
roads, by-roads, and even paths. Estimating the distance to march by their computation, it did not exceed nine miles, which we reckoned, dark as was the night, to make in two hours. Pushing on with all practicable despatch, the first hour brought us to a large road: this the guides passed, leading the detachment again into a thick wood. Here we continued another hour, when, finding no road, doubts began to be entertained by the guides, which issued at last in attempting to return to the very road they had passed, it being concluded to be the one desired. Unhappily they became bewildered, after changing their course, sometimes to the right, sometimes to the left, ever believing every change would surely bring us to our desired route, and yet always disappointed.

At length, with great anxiety, they proposed a halt, while themselves, accompanied by a few dragoons, should take different directions on our flanks in search of a house. This was readily acceded to, and the detachment dismounted, having not before halted. In the space of an hour one of them returned, and shortly after the other, both without success. It was now three o'clock, as well as we could make out the time by feeling the hour and minute hands of our watches. Again mounted, and again moved as our guides directed, more and more bewildered, and more and more distressed; persevering and yet in vain. Lieutenant Colonel Lee, apprehensive that the detachment might be carried too remote from the place assigned for junction in the morning with the militia under Clarke, again halted and dismounted, determining to wait for the light of day. It 
at last to our great joy appeared, and even then our guides were so completely out of their reckoning, as to detain us a long time in the woods before they were satisfied of the course to be taken.

By examining the bark of the trees they ascertained the north, and thus recovered their knowledge of our locality. We were within a mile of the road we had crossed, and which turned out to be the very road desired. When we passed it, the enemy were, as was afterwards ascertained, two miles only on our right, as much bewildered as ourselves. For, finding that they had not reached camp within the period expected, calculating time from distance; and knowing that New Garden must be upon their left: they took a cross road which offered, and soon found themselves encompassed with new difficulties, -fallen trees, and cross-ways, as large as the road they had pursued:- when the officer determined to halt and wait for day.* Lord Cornwallis

* Upon Lee's junction with Clarke, he found a packet from General Greene to Lord Cornwallis, which he sent off the ensuing morning by Cornet Middleton, of South Carolina, with a flag. The cornet reached the British picket just after the captain had breakfasted, and was politely invited to take breakfast, while the packet for his lordship should be sent to headquarters, from whence a reply would be forwarded, if requisite, which Middleton could convey. Cornwallis was on his rounds, agreeably to his custom; and soon after Middleton had finished his breakfast, called at the picket, when he was informed by the captain, of the packet from General Greene, with his detention of the officer for the answer, if any was requisite. His lordship dismounting, entered the captain's quarters, where Cornet Middleton was introduced to him. Presuming from his dress that he belonged to Lee's legion, he asked if he did not belong to that corps ; and being answered in the affirmative, with a smile he significantly 
became extremely alarmed for the safety of his baggage; despatching parties of horse and foot in various directions to fall in with it, and detaching in the rear of these parties a strong corps to reinforce the escort. Not one of the various detachments either met with the escort or with Lee. As soon as it was light, the officer having charge of the baggage retraced his steps; and shortly after gaining the road he had left in the night, fell in with the last detachment sent by Lord Cornwallis, and with it safely reached the British camp; while Lieutenant Colonel Lee and his harassed legion, with his afflicted guides, much mortified, joined Clarke. Here he found orders from General Greene, now nearly prepared for forward movement, to return to camp. The British General remained in his new position; enjoying, without interruption, the wholesome supplies with which this fertile settlement abounded. Lee having proceeded towards the Iron Works, found the American army on the 14th at Guilford court-house, distant about twelve inquired where it had been the preceding night. The amiable Middleton, somewhat surprised and confounded at a query so unexpected, with evident confusion replied, that it had not been far off. Upon which Lord Cornwallis familiarly said, the object of his inquiry was unimportant, the matter to which it related being past; and that he asked the information to gratify his curiosity. Middleton, blushing, then told him, that Lieutenant Colonel Lee had received intelligence of his lordship's escort, with the baggage and stores, being lost in the night, and instantly proceeded in the expectation of putting them in the right course. This idea tickling the British general, he laughingly asked, "Well, why did he not do it ?" " Because," says Middleton, "we got lost ourselves; traversing the roads all night, and as it appeared afterwards within two miles of our much desired prize." Turning to his aids, Cornwallis said, "You see I was not mistaken." 
miles from the enemy; and was immediately advanced on the road towards the Quaker meeting-house, with orders to post himself within two or three miles of the court-house, and to resume his accustomed duties. Lieutenant Heard, of the legion cavalry, was detached in the evening with a party of dragoons to place himself near the British camp, and to report from time to time such occurrences as might happen. About two in the morning this officer communicated, that a large body of horse were approaching the meeting-house, which was not more than six miles from our headquarters, and near the point where the road from Deep river intersects the great road leading from Salisbury to Virginia. The intelligence received was instantly forwarded to the general, and Heard was directed to proceed with a few of his dragoons down the flank of the enemy to discover whether the British army was in motion, leaving his second to hold their front. Hearing from Heard, agreeably to rule, every half hour, it was known that the enemy continued, though slowly, to approach; and at length he communicated, that his various attempts to pass down the flank as directed, had proved abortive, having been uniformly interrupted by patrols ranging far from the line of march; yet that he was persuaded that he heard the rumbling of wheels, which indicated a general movement. This being made known to General Greene, Lee was directed to advance with his cavalry, bear down these interruptions, and to ascertain the truth. Expecting battle as soon as Heard's last information was received, the van was called to arms at four in the morning, and to take breakfast with all practica- 
ble haste. This had just been finished, when the last mentioned order from the general was communicated. Lieutenant Colonel Lee instantly mounted, and took the road to the enemy, at the head of the horse, having directed the infantry and the rifle militia to follow, the first on his right, and the second on his left. The cavalry had not proceeded above two miles when Lee was met by Lieutenant Heard and his party, who were retiring, followed leisurely by the enemy's horse. Wishing to approach nearer to Greene, and at all events to gain the proximity of the rifle militia and legion infantry, lest the British army might be up, as was suspected, Lee ordered the column to retire by troops, taking the proper distance for open evolution. The rear troop under Rudulph going off in full gallop, and followed in like manner by the centre troop under Eggleston, the British commandant flattered himself with converting this retrogade movement into route, and pressed upon the front under Armstrong, still in a walk, it being necessary to gain the open order required, that this officer should not change his pace. With him marched Lieutenant Colonel Lee, attentively watching the British progress. Finding that the charge made at us did not affect Armstrong's troop, now the rear, the enemy emptied their pistols, and then raising a shout, pushed a second time upon Armstrong; who, remaining firm and sullen as before, the leading section having nearly closed with us, drew up.

At this moment, Lee ordering charge, the dragoons came instantly to the right about, and, in close column, rushed upon the foe. This meeting happened in a long 
lane, with very high curved fences on each side of the road, which admitted but one section in front. The charge was ordered by Lee, from conviction that he should trample his enemy under feet, if he dared to meet the shock, and thus gain an easy and complete victory. But only the front section of each corps closed, Tarleton sounding a retreat, the moment he discovered the column in charge. The whole of the enemy's section was dismounted, and many of the horses prostrated,* some of the dragoons killed, the rest made prisoners; not a single American soldier or horse injured. Tarleton retired with celerity, and getting out of the lane, took an obscure way leading directly across the Salisbury road towards the British camp; while Lee, well acquainted with the country, followed the common route by the Quaker meeting-house, with a view to sever the British lieutenant colonel from his army by holding him well upon his left, and with the determination to gain his front, and then to press directly upon him with his condensed force, and thus place his horse between Tarleton and Cornwallis, presumed to be some distance behind.

* This is not stated with a view to extol one, or disparage the other corps ; but merely to state the fact. Lieutenant Colonel Tarleton was obliged to use such horses as he could get; whereas his opponent had the whole South to select out of. The consequence was, the British dragoons were mounted upon small weak horses : those of the legion, on stout, active horses, and kept in the highest condition. When they met, the momentum of the one must crush the other ; and if he fled, he could not escape from his enemy so excellently mounted. There was very little credit, with such superior means, due to the Americans upon victory ; whereas, the disgrace of defeat would have been extreme, and Lee's corps ought to have been decimated. 
By endeavoring to take the whole detachment, he permitted the whole to escape; whereas, had he continued to press on the rear, he must have taken many. As Lee, with his column in full speed, got up to the meeting-house, the British guards had just reached it, and displaying in a moment, gave the American cavalry a close and general fire. The sun had just risen above the trees, and shining bright, the refulgence from the British muskets, as the soldiers presented, frightened Lee's horse so as to compel him to throw himself off. Instantly remounting another, he ordered a retreat. This manœuvre was speedily executed; and while the cavalry were retiring, the legion infantry came running up with trailed arms, and opened a well aimed fire upon the guards, which was followed in a few minutes by a volley from the riflemen under Colonel Campbell, who had taken post on the left of the infantry. The action became very sharp, and was bravely maintained on bath sides.* The cavalry having formed again in column,

* The British sustained a much heavier loss in killed and wounded than we did. His flre was innocent, overshooting the cavalry entirely, whose caps and accontrements were all stuck with green twigs, cut by the British balls out of the large oaks in the meeting-house yard, under which the cavalry received the volley from the guards. Some of the infantry and riflemen were killed, and more wounded: among them was Lieutenant Snowden, of the legion infantry, who, with most of the wounded, was necessarily left on the field.

Lee, after the battle of Guilford, wrote to Lieutenant Colonel Tarleton, asking his care of the legion and rifle corps; it being common for officers, in the habit of meeting in the course of service, mutually to solicit such favors. Tarleton very politely answered by an amanuensis, that he would with pleasure execute the request, and apologized for not writing himself, saying that he had received a ball in his right 
and Lee being convinced from the appearance of the guards, that Cornwallis was not far in the rear, drew off his infantry, and covering them from any attempt of the British horse, retired towards the American army. General Greene being immediately advised of what had passed, prepared for battle, not doubting that the long avoided, now wished for hour was at hand.

hand in our morning rencontre. Captain Schuty of the guards was badly wounded, with other officers and soldiers of that corps. 


\section{CHAPTER XIII.}

Battle of Guilford Court-house-Cornwallis's army greatly weakened by this action-Greene retreats to the Iron Works-Loss of the Americans in the battle-Loss of the British-Courage of the British troops-Desperate condition of Cornwallis-He retreats to Cross Creek-Greene pursues him-Cornwallis arrives at Wilmington-Greene gives over the pursuit-Greene resolves to carry the war into South Carolina-Cornwallis decides to proceed to Virginia.

Now came on the battle of Guilford Court-house. Having determined to risk an action, Greene chose his ground with judgment. Early in the morning of the 15th, the fire of his reconnoitring parties announced the approach of the enemy on the great Salisbury road, and his army was immediately arranged in order of battle. It was drawn up in three lines, on a large hill, surrounded by other hills, chiefly covered with trees and underwood.

The front line was composed of the two brigades of North Carolina militia, who were posted to great advantage on the edge of the wood, behind a strong rail fence, with an extensive open field in front.

The two brigades of Virginia militia formed the second line. They were drawn up entirely in the wood, about 
three hundred yards in rear of the first, and on either side of the great Salisbury road.

The third line was placed about three hundred yards in rear of the second, and was composed of continental troops. The Virginia brigade, commanded by General Huger, was on the right; that of Maryland, commanded by Colonel Williams, was on the left. They were drawn up obliquely, with their left diverging from the second line, and partly in open ground.

The first and third regiments of dragoons, amounting to one hundred and two troopers, Kirkwood's company of light infantry, and a regiment of militia riflemen under Colonel Lynch, formed a corps of observation for the security of the right flank, which was commanded by Lieutenant Colonel Washington. The legion, consisting: of one hundred and sixty-eight horse and foot, and a body of riflemen commanded by Colonels Campbell and Preston, formed a corps of observation for the security of the left flank, which was placed under Lieutenant Colonel Lee. The artillery was in the front line, in the great road leading through the centre, with directions to fall back as the occasion should require.

Though Lord Cornwallis was sensible that the numbers of the American army were greatly augmented by troops whose continuance in service would be of short duration, he deemed it so important to the interests of his sovereign to maintain the appearance of superiority in the field, that he was unwilling to decline the engagement now offered him.

On the advance of Greene, therefore, he prepared for action; and early in the morning moved from his ground, 
determined to attack the adverse army wherever it should be found. About four miles from Guilford court-house, the advance, led by Lieutenant Colonel Tarleton, fell in with Lee, and the sharp skirmish ensued described in the last chapter, which was terminated by the appearance of such large bodies of British troops, as rendered it prudent for Lee to retire. His Lordship continued to advance until he came within view of the American army. His disposition for the attack was then made in the following order.

The seventy-first British regiment, with the German regiment of Bose, led by General Leslie, and supported by the first battalion of the guards under Colonel Norton, formed the right; and the twenty-third and thirty-third regiments, led by Lieutenant Colonel Webster, and supported by Brigadier General O'Hara with the grenadiers and second battalion of the guards, formed the left. The light infantry of the guards and the Yagers, posted in the wood on the left of the artillery, and the cavalry in column behind it in the road, formed a corps of observation.

This disposition being made, the British troops adranced to the charge, with the cool intrepidity which discipline inspires.

The North Carolina militia were not encouraged by the great advantages of their position to await the shock. They broke instantly; and, throwing away their arms and flying through the woods, sought their respective homes.

The British then advanced on the second line, which received them with more firmness; and maintained their 


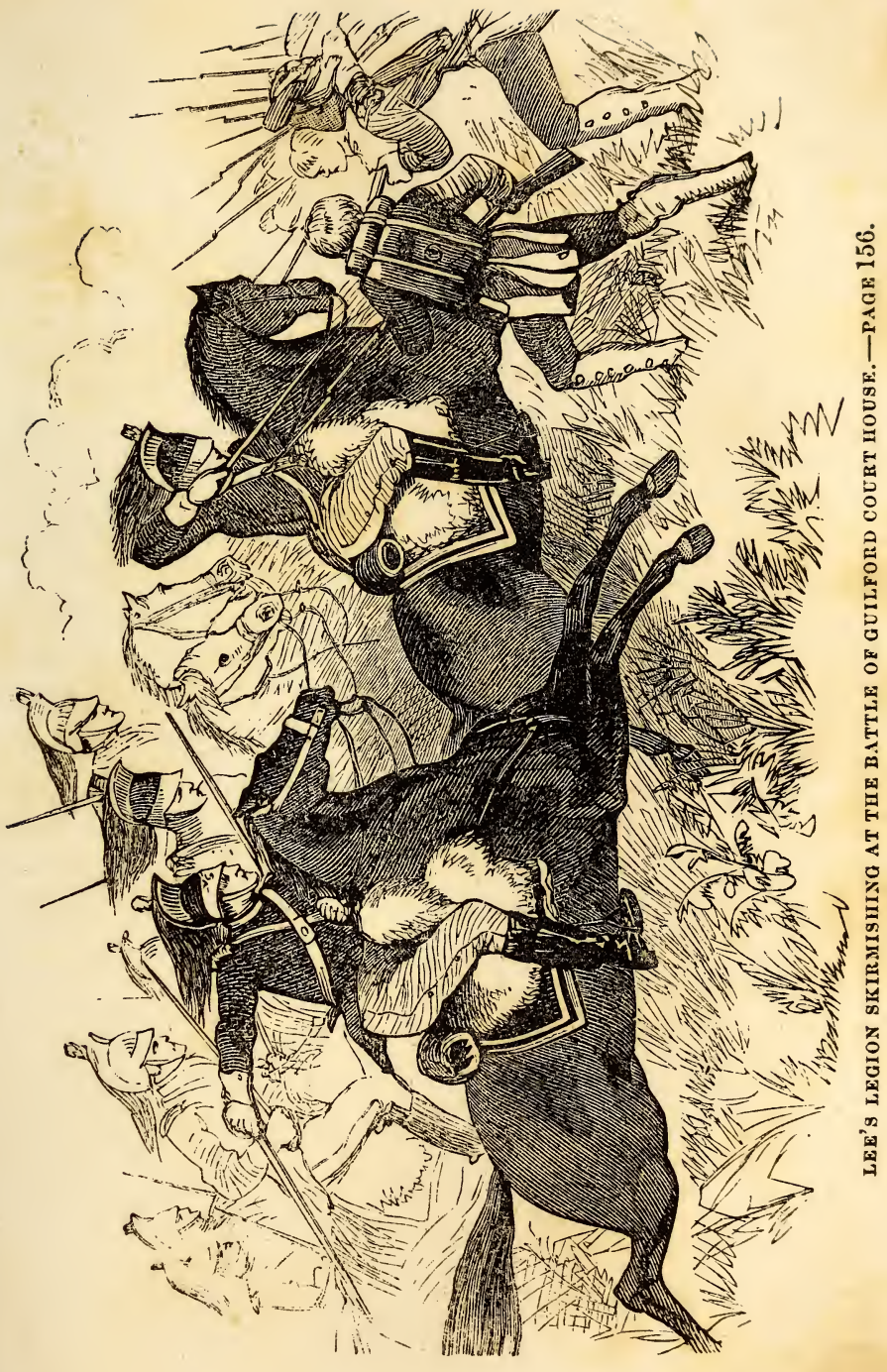



ground for some time with great resolution. Lord Cornwallis, perceiving the corps on his flanks, brought the whole of his reserved infantry into the line. On the right, General Leslie brought up the guards to oppose Lee; and, on the left, Webster changed his front to the left, and attacked Washington, while the grenadiers and second battalion of guards moved forward to occupy the placc which he had just quitted.*

The ground being unfavorable to the action of horse, Washington had posted Lynch's riflemen, with whom he remained in person, on a height covered with thick woods; and had drawn up his cavalry and continental infantry about one hundred yards in their rear. On being attacked by Webster, the riflemen broke; and Washington, finding it impossible to rally them, rejoined his cavalry.

The British continuing to advance, and it being well understood that the militia could not stand the bayonet, General Stevens, who had received a ball in his right thigh, ordered his brigade to retreat. Lawson's brigade having given way a short time before, the second line was entirely routed; and the enemy advanced boldly on the third.

The several divisions of the British army had been separated from each other by extending themselves to the right and left in order to encounter the distinct corps which threatened their flanks; and by advancing in regiments at different times, as the different parts of the second line had given way. The thickness of the wood increased the difficulty of restoring order. They * Letter of Lord Cornwallis._Stedman. 
pressed forward with great eagerness, but with a considerable degree of irregularity.

Greene, in this state of the action, entertained the most sanguine hopes of a complete victory. His continental troops were fresh, in perfect order, and upon the point of engaging an enemy, broken into distinct parts, and probably supposing the severity of the action to be over. This fair prospect was blasted by the misconduct of a single corps. The second regiment of Maryland was posted at some distance from the first, in open ground; its left forming almost a right angle with the line, so as to present a front to any corps which might attack on that flank. The British in advancing, inclined to the right; and the second battalion of guards entered the open ground immediately after the retreat of Stevens, and rushed on the second regiment of Maryland while the first was engaged with Webster. Without waiting to receive the charge, that regiment broke in confusion.

By pursuing them, the guards were thrown into the rear of the first regiment, from which they were concealed by the unevenness of the ground and by a skirt of wood.

Greene was himself on the left, and witnessed the misfortune without being able to remedy it. His militia being entirely routed, the flight of one-fourth of his continental troops would most probably decide the fate of the day. Unwilling to risk his remaining three regiments, only one of which could be safely relied on, without a man to cover their retreat should the event prove unfortunate, he ordered Colonel Greene of Virginia to withdraw his regiment from the line, and to take a posi- 
tion in the rear, for the purpose of affording a rallying point, and of covering the retreat of the two regiments which still continued in the field.

The guards were soon called from the pursuit of the second Maryland regiment, and led by Lieutenant Colonel Stuart against the first. About this time Webster, finding himself overpowered by the first Maryland regiment, then commanded by Colonel Gunby, and by Kirkwood's company and the remaining regiment of Virginia, with whom he was engaged at the same time, had in a great measure withdrawn from the action, and retired across a ravine into an adjoining wood. This critical respite enabled Gunby to provide for the danger in his rear. Facing about, he met the guards, and a very animated fire took place on both sides, during which the Americans continued to advance.

In this critical moment, Lieutenant Colonel Washington, who was drawn to this part of the field by the vivacity of the fire, made a furious charge upon the guards and broke their ranks. At this juncture, Gunby's horse was killed under him, and the command devolved on Lieutenant Colonel Howard. The regiment advanced with such rapidity that Gunby could not overtake it, and was within thirty yards of the guards when they were charged by the cavalry. Almost at the same instant the Maryland infantry rushed upon them with the bayonet, and following the horse through them, were masters of the whole battalion. In passing through it, Captain Smith of the infantry killed its commanding officer.

After passing through the guards into the open ground 
where the second regiment had been originally posted, Howard perceived several British columns, with some pieces of artillery. Believing his regiment to be the sole infantry remaining in the field, he retreated in good order, and brought off some prisoners. The cavalry also retreated.*

About the same time the remaining Virginia regiment commanded by Colonel Hawes, and Kirkwood's infantry, who were still engaged with Webster, were directed by General Greene to retreat. The artillery was unavoidably abandoned; the horses which drew the pieces being killed, and the woods too thick to admit of their being dragged elsewhere than along the great road. The retreat was made in good order, and Greene, in person, brought up the rear.

Though the action was over on the right and centre, Campbell's riflemen still maintained their ground on the extreme of the American left, against General Leslie with the regiment of Bose and the first battalion of guards.

After the guards had routed the brigade commanded by Lawson, they were attacked on their right flank by

* After passing through the guards into the cleared ground, Washington, who always led the van, perceived an officer surrounded by several persons who appeared to be aids-de-camp. Believing this to be Cornwallis, he rushed forward in the hope of making him a prisoner, but was arrested by an accident. His cap fell from his head, and, as he leaped to the ground to recover it, the officer leading the column was shot through the body, and rendered incapable of managing his horse. The animal wheeled round with his rider, and galloped off the field. He was followed by all the cavalry, who supposed that this movement had been directed. 
the infantry of Lee's legion, and by Campbell's riflemen, and were driven behind the regiment of Bose, which having moved with less impetuosity, was advancing in compact order.

This regiment sustained the American fire until Lieutenant Colonel Norton was able to rally the guards, and to bring them back to the charge; after which the action was maintained with great obstinacy on both sides until the battle was decided on the right. Lieutenant Colonel Tarleton was then ordered to the support of Leslie. The legion infantry had retreated, and only a few resolute marksmen remained in the rear of Campbell who continued firing from tree to tree. Being unable to resist a charge of cavalry, they were quickly driven from the field.

Two regiments of infantry and a detachment of cavalry pursued the right wing and centre of the Americans for a short distance, but were soon ordered to return. On examining his situation, Lord Cornwallis found himself too much weakened, and his troops too much fatigued by the action, to hazard its renewal or to continue the pursuit. General Greene halted about three miles from the field of battle, behind Rudy fork creek, for the purpose of collecting his stragglers; after which he retired about twelve miles to the Iron Works on Troublesome creek, the place appointed for the rendezvous of his army in the event of its being defeated.

The returns made immediately after the action, exhibited a loss in killed, wounded, and missing in the continental troops, of fourteen commissioned officers, and three hundred and twelve non-commissioned officers and privates. Major Anderson, a valuable officer of Mary- 
land, was killed; and General Huger, who commanded the continental troops of Virginia, was wounded.

The same return states the loss of the militia at four captains and seventeen privates killed; and, in addition to General Stevens, one major, three captains, eight subalterns, and sixty privates were wounded. A great proportion of this part of the army was missing; but it seems to have been expected that they would either rejoin their corps, or be found at their homes.

The victory of Guilford was dearly purchased. Official accounts state the loss of the British army at five hundred and thirty-two men, among whom were several officers of high rank and distinguished merit. Lieutenant Colonel Stuart of the guards was killed, and Lieutenant Colonel Webster, who was ranked by his enemies among the best officers in the British service, was mortally wounded. This loss, when compared to the numbers brought by Lord Cornwallis into the field, was very considerable. The Americans did not compute his troops at more than two thousand rank and file, but his own accounts state them at only fourteen hundred and forty-five.

No battle in the course of the war reflects more honor on the courage of the British troops, than that of Guilforl. On no other occasion have they fought with such inferiority of numbers, or disadvantage of ground. Estimating his first line at nothing, General Greene's army consisted of three thousand two hundred men, posted on ground chosen by himself; and his disposition was skillfully made.

The American general, expecting to be again attacked, 
prepared for another engagement. But the situation of Lord Cornwallis had become too desperate to hazard a second battle, or to maintain his position. He found himself under the necessity of retreating to a place of greater security, where provisions might be obtained.

When the expedition into North Carolina was originally meditated, Major Craig, at the head of a small military and naval force, took possession of Wilmington, a town near the mouth of Cape Fear, and extended his authority several miles up the river. Lord Cornwallis now looked to a communication with this post for aids which had become indispensable to the farther operations of the campaign.

On the third day after the battle, he broke up his encampment, and proceeded by slow and easy marches towards Cross creek.

General Greene, on hearing that the British army was retreating, resolved to follow it. The difficulty of subsisting the troops in an exhausted and hostile country, and the necessity of waiting for a supply of ammunition, impeded the march of his army so much that he did not reach Ramsay's mills until the 28th of March.

At this place Lord Cornwallis bad halted, and here General Greene expected to overtake and attack him. But, on the approach of the American army, his lordship resumed his march to Cross creek, and afterwards to Wilmington, where he arrived on the 7th of April.

General Greene gave over the pursuit at Ramsay's mills. So excessive had been the sufferings of his army from the want of provisions, that many of the men fainted on the march, and it had become absolutely ne- 
cessary to allow them some repose and refreshment. The expiration of the time for which the Virginia militia had been called into service, furnished an additional motive for suspending the pursuit.

At this place, the bold and happy resolution was taken to carry the war into South Carolina.

The motives which induced the adoption of this measure were stated by himself in a letter communicating his determination to the commander-in-chief. It would compel Lord Cornwallis to follow him, and thus liberate North Carolina, or to sacrifice all his posts in the upper parts of South Carolina and Georgia.

The Southern army amounted to about seventeen hundred effectives. That of Lord Cornwallis is understood to have been still less numerous. So impotent were the means employed for the conquest and defence of States which were of immense extent and value.

This unexpected movement gave a new aspect to affairs, and produced some irresolution in the British general respecting his future operations. After weighing the probable advantages and disadvantages of following Greene into South Carolina, he decided against this retrograde movement, and determined to advance into Virginia. 


\section{CHA P TER XIV.}

Lee ordered to join Marion on the Pedee-Movements of General Greene-Battle of Hobkirk's Hill-Lord Rawdon determines to evacuate Camden-Exultation of Greene-Lee and Marion capture Fort Watson-Colonel Watson joins Lord Rawdon-They menace Greene but do not attack him-Lee and Marion besiege and capture Fort Motte-Noble conduct of Mrs. Motte-Lee proceeds to Fort Granby-General Sumter captures the post at Orangeburgh.

ON resolving to carry the war into South Carolina, General Greene detached Lee to join Marion on the Pedee. Taking the road by Cross Creek and Downing Creek, Lee effected his junction with Marion on the 8th of March 1781.

General Greene appeared before Camden with the design of attacking Lord Rawdon who was stationed at that post, but finding it too strong, he fell back about two miles and took post at Hobkirk's Hill. Here he was attacked by Lord Rawdon on the 25th of April. A hard fought battle ensued, and through some false more on the part of his troops Greene was obliged to retreat. Rawdon did not pursue; but returned to Camden.

Greene now expected to be driven to the mountains; but Rawdon, learning that Lord Cornwallis was gone to Virginia, determined to evacuate Camden. Greene writing to General Davis, said, "Rawdon is preparing to 
evacuate Camden; that place was the key of the enemy's line of forts; they will now all fall or be evacuated. All will now go well. * * I shall march immediately to the Congaree.

His words were prophetic; for now commenced the final reconquest of the Southern States, in which Lee was destined to take an active part.

The first object of attack was Fort Watson.

Determined, says Lee, ${ }^{*}$ to carry this post without delay, Marion and Lee sat down before it early in the evening; not doubting, from the information received, that the garrison must soon be compelled to surrender, for want of water, with which it was supplied from an adjacent lake, and from which the garrison might be readily and effectually secluded. In a very few hours the customary mode of supplying the post with water was completely stopped; and had the information received been correct, a surrender of the garrison could not have been long delayed. The ground selected by Colonel Watson for his small stockade, was an Indian mount, generally conceived to be the cemetery of the tribe inhabiting the circumjacent region: it was at least thirty feet high, and surrounded by table land. Captain M·Koy, the commandant, saw at once his inevitable fate, unless he could devise some other mode of procuring water, for which purpose he immediately cut a trench from his fosse, (secured by abatis) to the river, which passed close to the Indian mount. Baffled in their expectation, and destitute both of artillery and intrenching tools, Marion and Lee despaired of success; when Major Mayham, of

* Memoirs. 
South Carolima, accompanying the brigadier, suggested a plan, which was not sooner communicated than gratefully adopted. He proposed to cut down a number of suitable trees in the nearest wood, and with them to erect a large, strong, oblong pen, to be covered on the top with a floor of logs, and protected on the side opposite to the fort with a breastwork of light timber. To the adjacent farms dragoons were despatched for axes, the only necessary tool, of which a sufficient number being soon collected, relays of working parties were allotted for the labor; some to cut, some to convey, and some to erect. Major Mayham undertook the execution of his plan, which was completely finished before the morning of the $23 \mathrm{~d}$, effective as to the object, and honorable to the genius of the inventor. The besieged was, like besieger, unprovided with artillery, and could not interrupt the progress of a work, the completion of which must produce immediate submission.

A party of riflemen, being ready, took post in the Mayham tower the moment it was completed; and a detachment of musketry, under cover of the riflemen, moved to make a lodgment in the enemy's ditch, supported by the legion infantry with fixed bayonets. Such , was the effect of the fire from the riflemen, having thorough command of every part of the fort, from the relative supereminence of the tower, that every attempt to resist the lodgment was crushed. The commandant, finding every resource cut off, hung out the white flag. It was followed by a proposal to surrender, which issued in a capitulation. This incipient operation having been happily effected by the novel and effectual device of Major 
Mayham, to whom the commandants very gratefully expressed their acknowledgment, Marion and Lee, preceded by the legion cavalry under Major Rudulph, who had been detached on the day subsequent to the investiture of the fort, turned their attention to Lieutenant Colonel Watson, now advancing from below to relieve his garrison. Knowing that the fall of Camden was closely connected with the destruction of Watson, the American commandants viewed with delight his approach; and having disposed of the prisoners, moved to join the cavalry, now retiring in front of the enemy.

After the surrender, Lee received orders from Greene to rejoin him; but these orders were countermanded, when he was on his way, and he returned to Marion, joining him near the confluence of the Congaree and Wateree, where he was waiting for the advance of Col. Watson. The object in view was to prevent Watson from joining Lord Rawdon at Camden; but Watson eluded their pursuit and effected the junction. Thus reinforced, Rawdon marched out of Camden to attack Greene, but finding him in too strong a position, on Colonel's Creek, he returned to Camden; it was then that he determined to abandon Camden, as mentioned above. Meantime, Lee and Marion were engaged in the siege of Fort Motte.

On the 10th of May the evacuation of Camden took place, and the British General proceeded to Nelson's ferry, with the expectation of crossing the Santee in time to dislodge Marion and Lee, still prosecuting the siege of Fort Motte. Previous to his lordship's departure, he burnt the jail, the mills, and some private bouser, and 
destroyed all the stores which he could not take with him. He carried off four or five hundred negroes, and all the most obnoxious loyalists accompanied him.

As soon as Greene was informed of the retreat of the enemy, persuaded that Rawdon's first effort would be directed to relieve Fort Motte, he advanced towards the Congaree, determined to pass that river, if necessary, and cover the operations of the besieging corps.

This post was the principal depot of the convoys from Charleston to Camden, and sometimes of those destined for Fort Granby and Ninety-Six. A large new mansion house, belonging to Mrs. Motte, situated on a high and commanding hill, had been selected for this establishment. It was surrounded with a deep trench, along the interior margin of which was raised a strong and lofty parapet. To this post had been regularly assigned an adequate garrison of about one hundred and fifty men, which was now accidentally increased by a small detachment of dragoons, which had arrived from Charleston a few hours before the appearance of the American troops, on its way to Camden with despatches for Lord Rawdon. Captain M'Pherson commanded, an officer highly and deservedly respected.

Opposite to Fort Motte, to the north, stood another hill, where Mrs. Motte, having been dismissed from her mansion, resided in the old farmhouse. On this height Lieutenant Colonel Lee with his corps took post, while Brigadier Marion occupied the eastern declivity of the ridge on which the fort stood.

Very soon the fort was completely invested; and the six pounder was mounted on a battery erected in Mari- 
on's quarter, for the purpose of raking the northern face of the enemy's parapet, against which Lee was preparing to advance. M'Pherson was unprovided with artillery, and depended for safety upon timely relief, not doubting its arrival before the assailant could push his preparations to maturity.

The vale which runs between the two hills admitted our approach within four hundred yards of the fort. This place was selected by Lee to break ground. 'Relays of working parties being provided for every four hours, and some of the negroes from the neighboring plantations being brought, by the influence of Marion, to our assistance, the works advanced with rapidity. Such was their forwardness on the 10th, that it was determined to summon the commandant.

A flag was accordingly despatched to Captain M'Pherson, stating to him with truth our relative situation, expressing with decision the fate which awaited him, and admonishing him to avoid the disagreeable consequences of an arrogant temerity. To this the captain replied, that, disregarding consequences, he should continue to resist to the last moment in his power. The retreat of Rawdon was known in the evening to the besiegers, and in the course of the night a courier arrived from General Greene, confirming that event, urging redoubled activity, and communicating his determination to hasten to their support. Urged by these strong considerations, Marion and Liee persevered throughout the night in pressing the completion of their works. On the next day, Rawdon reached the country opposite to Fort Motte; and in the succeeding night, encamping on the highest ground in 
his route, the illumination of his fires gave the joyful annunciation of his approach to the despairing garrison. But the hour was close at hand, when this fallacious joy was to be converted into sadness.

The large mansion in the centre of the encircling trench, left but a few yards of the ground within the enemy's works uncovered: burning the house must force their surrender.

Persuaded that our ditch would be within arrow shot before noon of the next day, Marion and Lee determined to adopt this speedy mode of effecting their object. Orders were instantly issued to prepare bows and arrows, with missive combustible matter. This measure was reluctantly adopted; for the destruction of private property was repugnant to the principles which swayed the two commandants, and upon this occasion was peculiarly distressing. The devoted house was a large, pleasant edifice, intended for the summer residence of the respectable owner, whose deceased husband had been a firm friend to his oppressed country, and whose only marriageable daughter was the wife of Major Pinckney, an officer in the South Carolina line, who had fought and bled in his country's cause, and was now a prisoner with. the enemy. These considerations powerfully forbade the execution of the proposed measure; but there were others of much cogency, which applied personally to Lieutenant Colonel Lee, and gave a new edge to the bitterness of the scene.

Encamping contiguous to Mrs. Motte's dwelling, this officer had, upon his arrival, been requested in the most pressing terms to make her house his quarters. The in- 
vitation was accordingly accepted; and not only the lieutenant colonel, but every officer of his corps, off duty, daily experienced her liberal hospitality, politely proffered and as politely administered. Nor was the attention of this amiable lady confined to that class of war which never fail to attract attention. While her richly spread table presented with taste and fashion all the luxuries of her opulent country, and her sideboard offered without reserve the best wines of Europe-antiquated relics of happier days-her active benevolence found its way to the sick and to the wounded; cherishing with softest kindness infirmity and misfortune, converting despair into hope, and nursing debility into strength. Nevertheless the imperative obligations of duty must be obeyed; the house must burn, and a respectful communication to the lady of her destined loss must be made. Taking the first opportunity which offered, the next morning, Lieutenant Colonel Lee imparted to Mrs. Motte the intended measure, lamenting the sad necessity, and assuring her of the deep regret which the unavoidable act excited in his and every breast.

With the smile of complacency this exemplary lady listened to the embarrassed officer, and gave instant relief to his agitated feelings, by declaring, that she was gratified with the opportunity of contributing to the good of her country, and that she should view the approaching scene with delight. Shortly after, seeing accidentally the bow and arrows which had been prepared, she sent for Lee, and presenting him with a bow and its apparatus imported from India, she requested his substitution of 
these, as probably better adapted for the object than those we had provided.

Receiving with silent delight this opportune present, Lee rejoined his troops, now making ready for the concluding scene. The lines were manned, and an additional force stationed at the battery, lest the enemy, perceiving his fate, might determine to risk a desperate assault, as offering the only chance of relief. As soon as the troops reached their several points, a flag was again sent to $M$ 'Pherson, for the purpose of inducing him to prevent the conflagration and the slaughter which might ensue, by a second representation of his actual condition.

Doctor Irvin, of the legion cavalry, was charged with the flag, instructed to communicate faithfully the inevitable destruction impending, and the impracticability of relief, as Lord Rawdon had not yet passed the Santee; with an assurance that longer perseverance in vain resistance, would place the garrison at the mercy of the conqueror ; who was not regardless of the policy of preventing the waste of time, by inflicting exemplary punishment, where resistance was maintained only to produce such waste. The British captain received the flag with his usual politeness, and heard patiently Irvin's explanations; but he remained immovable; repeating his determination of holding out to the last.

It was now about noon, and the rays of the scorching sun had prepared the shingle roof for the projected conflagration. The return of Irvin was immediately followed by the application of the bow and arrows. The first arrow struck, and communicated its fire; a second 
was shot at another quarter of the roof, and a third at a third quarter; this last also took effect, and, like the first, soon kindled a blaze. M'Pherson ordered a party to repair to the loft of the house, and by knocking off the shingles to stop the flames. This was soon perceived, and Captain Finley was directed to open his battery, raking the loft from end to end.

The fire of our six pounder, posted close to one of the gable ends of the house, soon drove the soldiers down; and no other effort to stop the flames being practicable, M'Pherson hung out the white flag. Mercy was extended, although policy commanded death, and the obstinacy of M'Pherson warranted it. The commandant, with the regulars, of which the garrison was chiefly composed, were taken possession of by Lee ; while the loyalists were delivered to Marion. Among the latter was a Mr. Smith, who had been charged with burning the houses of his neighbors friendly to their country. This man consequently became very obnoxious, and his punishment was loudly demanded by many of the militia serving under the brigadier; but the humanity of Marion could not be overcome. Smith was secured from his surrounding enemies, ready to devote him, and taken under the general's protection.

$\mathrm{M} \cdot$ Pherson was charged with having subjected himself to punishment, by his idle waste of his antagonists' time; and reminded as well of the opportunities which had been presented to him of saving himself and garrison from unconditional submission, as of the cogent considerations, growing out of the posture of affairs, which urged the prevention of future useless resistance by present 
exemplary punishment. The British officer frankly acknowledged his dependent situation, and declared his readiness to meet any consequence which the discharge of duty, conformably to his own conviction of right, might produce. Powerfully as the present occasion called for punishment, and rightfully as it might have been inflicted, not a drop of blood was shed, nor any part of the enemy's baggage taken. M'Pherson and his officers accompanied their captors to Mrs. Motte's, and partook with them in a sumptuous dinner ;* soothing in the sweets of social intercourse the ire which the preceding conflict had engendered. Requesting to be permitted to return to Charleston, on parole, they were accordingly paroled and sent off in the evening to Lord Rawdon, now engaged in passing the Santee at Nelson's ferry. Soon after, General Greene, anxious for the success of his detachment against Fort Motte, attended by an escort of cavalry, reached us, for the purpose of knowing precisely our situation, and the progress of the British general, who he expected would hasten to the relief of M'Pherson, as soon as he should gain the southern banks of the Santee; to counteract which the American general had resolved, and was then engaged in preparing boats, to transport his army over the Congaree. Finding the siege prosperously concluded, he returned to camp;

* The deportment and demeanor of Mrs. Motte gave a zest to the pleasures of the table. She did its honors with that unaffected politeness, which ever excites esteem mingled with admiration. Conversing with ease, vivacity, and good sense, she obliterated our recollection of the injnry she had received; and though warmly attached to the defenders of her country, the engaging amiability of her manners left it doubtful which set of officers constituted these defenders. 
having directed Marion, after placing the prisoners in security, to proceed against Georgetown, and ordering Lee to advance without delay upon Fort Granby, to which place the American army would now move. As soon as the troops had finished their repast, Lee set out with his detachment, composed of horse, foot, and artillery; and marching without intermission, he approached the neighborhood of Fort Granby before the dawn of the second day. Brigadier Sumter, having recovered of his wound, as soon as he received Greene's despatch from Ramsay's mill, assembled his corps of militia. For reasons not understood by the author, the brigadier, instead of joining Greene before Camden, directed his attention to the fort of Ninety-Six and its upper communications with Charleston, Fort Granby, and Orangeburgh. He had moved from before Fort Granby, but a few days before Lee's arrival, for the purpose of forcing the small post at Orangeburgh, which he accomplished on the 14 th. 


\section{CHAPTER X V.}

Position of Fort Granby-Lee lays siege to it-Summons the garrison-Negotiations-Capitulation of Fort Granby-The garrison retires-Public stores surrendered-Lee apprises General Greene of his success-Greene visits him and commends the conduct of the legion-Iord Rawdon retreats to Monk's Corner, relinquishing his line of posts-Great success of the Americans-Two States recovered in one month.

Font Granby was erected on a plain, which extended to the southern banks of the Congaree, near Friday's ferry. Protected on one side by that river, it was accessible in every other quarter with facility; but being completely finished, with parapet encircled by fosse and abattis, and being well garrisoned, it could not have been carried without considerable loss, except by regu* lar approaches; and in this way would have employed the whole force of Greene for a week at least, in which period Lord Rawdon's interposition was practicable. Lee, apprized of the readiness with which the British general might attempt its relief, determined to press to conclusion his operations with all possible celerity, having detached, before he left Motte's, Captain Armstrong, with one troop of cavalry, to attend to the movements of Lord Rawdon.

As soon, therefore, as he reached the neighborhood of 12 
the fort, relying upon the information of his guides, he began to erect a battery in the margin of the woods to the west of the fort. The morning was uncommonly foggy, which fortunate circumstance gave time to finish the battery before it was perceived by the enemy.

Captain Finley, with his six pounder mounted in the battery, was directed as soon as the fog should disperse to open upon the fort; when the infantry, ready for action, would advance to gain the ground selected for the commencement of our approaches.

The garrison consisted of three hundred and fifty men, chiefly loyal militia, commanded by Major Maxwell, of the Prince of Wales' regiment, (a refugee from the Eastern Shore of Maryland,) represented to Lee as neither experienced in his lately adopted profession, nor fitted by cast of character to meet the impending crisis. He was the exact counterpart of $\mathrm{M}$ 'Pherson; disposed to avoid, rather than to court, the daring scenes of war. Zealous to fill his purse, rather than to gather military laurels, he had, during his command, pursued his favorite object with considerable success, and held with him in the fort his gathered spoil.

Solicitous to hasten the surrender of the post, Lee determined to try the effect of negotiation with his pliable antagonist; and prepared a summons, couched in pompous terms, calculated to operate on such an officer as Maxwell was represented to be. The summons was entrusted to Captain Eggleston, of the legion horse, who was authorized to conclude finally upon the terms of capitulation, if he found the enemy disposed to surrender. 
The fog ceasing, Finley announced our unexpected proximity, which excited much alarm and some confusion, evidently discerned from our position. The legion infantry, advancing at the same time, took possession of the desired ground without opposition; severing the enemy's pickets in this quarter from the fort. Eggleston now setting out with his flag, produced a suspension of our fire, which induced the pickets and patrols, cut off by our disposition, to attempt to gain the fort.

This effort was partially checked by the rapid movement of the cavalry; and an officer was despatched to Captain Eggleston, requiring him to remonstrate to Major Maxwell upon the impropriety of the conduct of his pickets and patrols, with a demand that he would order them to resume their station; it being never intended, by presenting him with an opportunity of avoiding the useless effusion of blood, to permit the improvement of his capacity to resist. Eggleston's remonstrance was duly respected; and Maxwell despatched his adjutant with the required orders, replacing the portion of his force on duty out of the fort in its original station. The negotiation was begun, and the British major testified a favorable disposition to the proposition submitted to him. After consulting with some of his officers, he agreed to deliver up the fort, upon condition that the private property of every sort, without investigation of title, should be confirmed to its possessors; that the garrison should be permitted to return to Charleston prisoners of war, until exchanged; that the militia should be held in the same manner as the regulars; and that an escort, charged with the protection of persons 
and of property, should attend the prisoners to the British army.

The first condition being diametrically repugnant to the course contemplated by Lee, as it prevented restoration of plundered property, Captain Eggleston did not think proper to act under the full discretion with which he had been so properly invested, but submitted by letter the enemy's demands to the lieutenant colonel, accompanied with one from Major Maxwell, requiring two covered wagons for the conveyance of his own baggage, free from search. In reply, Eggleston received directions to accede to the proposed terms, with the single exception of all horses fit for public service, and to expedite the conclusion of the business. This exception was illy relished by many of the officers, although not resisted by the commandant. Finding that the capitulation would be thus arranged, the Hessian officers came in a body to Eggleston, protesting against proceeding, unless they were permitted to retain their horses; a protest not to be overruled by the authority of Maxwell. The capitulation was suspended, and a second time Eggleston found it necessary to refer to Lee. About this moment a dragoon arrived from Captain Armstrong, commanding the detachment of horse near Lord Rawdon, communicating his lordship's passage across the Santee, and his advance towards Fort Motte. Had Lee determined to resist the requisition of the Hessian officers, this intelligence would have induced a change in his decision. He directed Captain Eggleston to make known to the officers, that he took pleasure in gratifying them, by considering all horses belonging to individuals 
in the fort as private property, and claiming only such, if any, belonging to the public.

This obstacle being removed, the capitulation was signed; and the principal bastion was immediately occupied by Captain Rudulph, with a detachment from the legion infantry. Before noon, Maxwell, with his garrison, consisting of three hundred and forty men, (sixty regulars, the rest loyalists, ) its baggage of every sort, two pieces of artillery, and two covered wagons, moved from the fort; and the major with his garrison, protected by the stipulated escort, proceeded on their route to Lord Rawdon. The public stores of every sort, consisting chiefly of ammunition, salt, and liquor, were faithfully delivered, and presented a very convenient as well as agreeable supply to our army.

The moment Maxwell surrendered, Lee despatched an officer with the information to General Greene, who had pressed on with much expedition, and was within a few miles of Friday's ferry when he received Lee's despatch. The army continued its march to Ancran's plantation, near the ferry; and the general, crossing the river, joined his light corps.

Delighted with the happy termination which had just taken place, General Greene's satisfaction was considerably increased when he saw the strength of the fort, connected with that of the garrison. He testified with much cordiality, and in most gratifying terms, his obligations to the light corps; applauding as well the rapidity of its advance as the vigor of its operations.

Lord Rawdon made but one day's march towards Fort Motte; yielding up with much reluctance his anxious 
desire to defend his line of posts, already broken through in its weakest points, and about to be assailed throughout. Retiring to Monk's Corner, he there encamped; impatiently waiting for an accession of force to enable him to resume offensive operations.

Fort Watson, Fort Motte, Fort Granby, and that at . Orangeburgh, had successively yielded: Marion was now before Georgetown, which was sure soon to fall. Thus in less than one month since General Greene appeared before Camden, he had compelled the British general to evacuate that important post, forced the submission of all the intermediate posts, and was now upon the banks of the Congaree, in the heart of South Carolina, ready to advance upon Ninety-six, (the only remaining fortress in the state, besides Charleston, in the enemy's possession,) and to detach against Augusta, in Georgia; comprehending in this decisive effort, the completion of the deliverance of the two lost states, except the fortified towns of Charleston and Savannah,-safe, because the enemy ruled at sea. 


\section{CHAPTER XVI。}

Lee ordered to join Pickens in the siege of Augusta-Operations of Major Rudulph-Lee reaches Augusta-He hears of the Indian present of supplies, and determines to seize it-Sufferings of the troops on the march-Lee obtains the supplies-He sends Major Eggleston to summon Brown to surrender Augusta-Union of the whole besieging force-Lee defeats Grierson and captures one of the forts-Renewal of intercourse-Mayham tower built-Brown makes a sally and is repulsed with a severe loss-Brown's stratagem for burning the tower-Its failure-The deserter-The explosion-Brown surrenders Augusta-Lee saves Brown's life which is threatened by the Georgians-Pickens remains at Augusta-Lee joins General Greene at Ninety-six.

General Greene reposing his army for the day, and strengthening the light corps with a battalion of North Carolina levies under Major Eaton, directed Lee to move towards Augusta, to which post Brigadier Pickens, with his corps of militia, had been commanded to repair. Lee commenced his march in the course of a few hours, marching thirteen miles in the evening of the day on which Maxwell had surrendered. Resuming motion at a very early hour in the morning, he pressed forward with the utmost expedition, relieving the fatigued infantry by occasionally dismounting his dragoons and mounting his infantry. Not only the claim for celerity, arising out 
of the general state of affairs, enforced this exertion, but there was cause to apprehend that Lieutenant Colonel Cruger, apprised as was presumed, of Lord Rawdon's abandonment, first of Camden and lastly of the field, would, in consequence of these untoward events, hasten to Augusta; giving up South Carolina to save Georgia. To reach Pickens before Cruger could join Brown, became, in this view of events, of the first importance. Pickens and Lee united could readily strike Cruger on his march, with the prospect of bringing him to submission. This done, the destruction of Brown only remained to be effected for the complete re-annexation (except the sea coast) of these States to the Union.

Approaching in the course of his march, the point nearest Ninety-Six, Lee detached a squadron of horse, under Major Rudulph, towards that post, for the purpose of ascertaining whether the enemy exhibited the appearance of breaking up, and with the hope by this sudden dash of seizing some of the garrison,-a very acceptable present to the American general, then on his march for that place, and in want of that accurate information to be derived only from residents in the place.

Rudulph, concealing his approach, appeared suddenly near the town, but was not so fortunate as to find a single individual of the garrison without the lines. $\mathrm{He}$ seized one or two countrymen returning home, who accompanied him to camp. From these we learned that Lieutenant Colonel Cruger was uninformed of the events that had lately taken place; but hearing of Greene's advance upon Camden, he had been industriously engaged 
in strengthening his fortifications, and was determined not to abandon his post.

Lee despatched a friendly countryman to General Greene with the intelligence procured, which banished all those apprehensions heretofore entertained lest Cruger might unite himself to Brown. Persevering in his march, Lee reached on the third day the vicinity of Augusta, which is seventy-five miles from Fort Granby, preceded by Captain O'Neale, with a light party of horse, charged with the collection of provisions and with the acquirement of intelligence.

From this active and discerning officer, the pleasing information was received of the recent arrival of the annual royal present to the Indians, which was deposited at Fort Galphin, about twelve miles below Augusta, on the north side of the river, consisting of articles extremely wanted in the American camp.* To relieve the wants of the army was in itself grateful, but this intelligence was important in a military view, because it showed that Colonel Brown's force in Augusta was reduced by detachments from it to secure his deposit at Fort Galphin.

Two companies of infantry now made the garrison of this latter post, which was a small stockade. Persuaded that his approach was alike unknown to Brown and to the officer commanding here, from the precautions which, by means of his superior cavalry, he had been enabled to

* Powder, ball, small arms, liquor, salt, blankets, with sundry small articles, were gained, one of the many useful and valuable acquisitions occasionally procured by the legion; for which, of the promised remuneration, not a cent has been ever paid to officer or soldier. 
adopt, Lee determined by a forced march, with a detachment of infantry mounted behind his dragoons, to seize the Indian present. Leaving Eaton behind with his battalion, the artillery, and the tired of the corps, to follow, he accordingly pushed on to Fort Galphin.

On the ensuing morning (21st of May), sultry beyond measure, the fatigued detachment gained the desired point; and, halting in the pine barrens which skirted the field surrounding the fort, waited for the moment of assault. For many miles not a drop of water had been procurable; and the extreme heat of the scorching sun, rendered more oppressive by the necessary halt under the pines, without any liquid whatsoever to revive sinking nature, produced a debility forbidding exertion.

Having with him some mounted militia, Lee directed them to dismount and to advance upon the fort in the opposite direction-not doubting that the garrison, as was the custom, would eagerly pursue them, when an opportunity would be presented of obtaining the contemplated prize without loss. The major part of the garrison, as had been expected, ran to arms on sight of the militia, and, leaving the fort, pursued them. A selection having been made of all the infantry whose strength was fitted for action, a portion of them under Captain Rudulph was ordered to rush upon the fort, while the residue, supported by a troop of dragoons, took a direction which shielded the militia from the menaced blow. Rudulph had no difficulty in possessing himself of the fort, little opposition having been attempted, and that opposition having been instantly crushed. We lost one man from 
the heat of the weather; the enemy only three or four in battle.

The garrison, with the valuable deposit in its safe keeping, gave a rich reward for our toils and sufferings. Never was a beginning more auspicious. This success not only deprived Brown of a very important portion of his force, but yielded to his enemy an abundance of supplies much wanted by the army of Greene,-among which were the essentials of war, powder and ball-which articles had become scarce in the American camp, notwithstanding the occasional contributions of the several posts wrested from the enemy.

Lee, reposing his infantry for a few hours, detached Major Eggleston, at the head of his horse, to pass the Savannah below Augusta; and, taking a western direction, to join a corps of militia, known to be in the neighborhood, under Colonel Clarke, in case Brigadier Pickens should not yet have arrived. Eggleston was also ordered to make himself thoroughly acquainted with the enemy's situation for the information of his commandant, who wished to begin his operations the moment of his return; and was further enjoined to send in a flag with a summons from himself, stating the near approach of part of Greene's army, with the investiture of NinetySix by the main body under the general himself; and urging the propriety of sparing the useless waste of life - the certain consequence of resistance,-cruel, because vain.

The substitution of a second officer for his superior in summoning the fort arose from the course taken by Brown. $\mathrm{He}$ had refused to receive flags, forbidding all intercourse 
with the militia officers; and Lee, having profited by negotiation at Fort Granby, was desirous of removing the obstacles which prevented resort to the like course here. To effect this, he thought it advisable to authorize Eggleston, then the senior continental officer on the south of Savannah, to attempt negotiation. Brown, either discrediting the information contained in the summons, or immutable in the decision he had taken, would not answer the letter addressed to him, and forbade the renewal of such communication.

In the evening, Lee, with the artillery and infantry, joined Eggleston, then united to the militia under Pickens and Clarke, and encamped in the woods to the west of Augusta. This town is situated on the southern banks of the Savannah, in an oblong plain, washed by the river on the east and covered by deep woods in the opposite direction. In its centre stood Fort Cornwallis, judiciously constructed, well finished, and secure from storm. A half mile in its front up the river the plain is interrupted by a lagoon or swamp with a rivulet passing through it; and on the northwestern border of this lagoon was erected another fort, very inferior, called Grierson, from the militia colonel who commanded its garrison.

Brown conducted the British force in upper Georgia, and resided in Fort Cornwallis. Lee, hearing from Eggleston the affrontive rejection to his proffered negotiation, was considerably ruffled at the contemptuous treatment received, and determined never to enter into any communication with the British commandant until solicited by himself. Thus decided, he was gratified in discovering the divided condition of the enemy-its reg- 
ulars in Fort Cornwallis and its militia in Fort Grierson; not doubting, if the moment was duly improved, that a tender of negotiation, on the part of Brown, would follow.

While the troops, still, concealed, were engaged in taking refreshments, Lee employed himself in examining the ground. $\mathrm{He}$ did not hesitate in his decision, which was instantly to drive Grierson out of his fort, and to destroy or intercept him in his retreat to Fort Cornwallis.

Communicating his plan to Pickens and Clarke, it was adopted; and the troops were soon after arrayed for executing it.

Brigadier Pickens with the militia was to attack the fort on its north and west; Major Eaton with his battalion, by passing down the north side of the lagoon was to approach it on the south, co-operating with the militia; while Lee, with his infantry and artillery, was to move down the lagoon on its southern margin, parallel with Eaton, ready to support his attack if required, or to attend to the movements of Brown, should he venture to leave his defences and interpose with a view to save Grierson.

The cavalry, under Eggleston, were ordered to draw near to Fort Cornwallis, keeping in the wood and ready to fall upon the rear of Brown should he advance upon Lee. These arrangements being finished, the several commandants proceeded to their respective points. Lee's movement, open to view, was soon discerned by Brown, who, drawing his garrison out of his lines accompanied by two field pieces, advanced with the ap- 
pearance of risking battle to save Grierson, now assailed by Pickens and Eaton. This forward movement soon ceased. Brown, not deeming it prudent, under existing circumstances, to persevere in his attempt, confined his interposition to a cannonade, which was returned by Lee, with very little effect on either side. Grierson's resistance was quickly overpowered; the fort was evacuated; himself with his major and many of his garrison killed; the lieutenant colonel with others taken; and the few remaining, by reaching the river, escaped under cover and concealment of its banks to Fort Cornwallis.*

Lieutenant Colonel Brown, perceiving the fall of this post, withdrew into his fort; and apprehending, from what he had seen, that he had to deal with troops fitted for war, applied himself to strengthening his situation. Whatever was attainable in the town, and necessary to his defence, was now procured; and every part of the works requiring amendment was repaired with industry. These exertions on the part of the enemy could not be counteracted; all now to be done was to assume proper stations for close investiture, and, by regular approaches, to compel his surrender.

In the late contest our loss was trivial, - a few

* The militia of Georgia, under Colonel Clarke, were so exasperated by the cruelties mutually inflicted in the course of the war in this state, that they were disposed to have sacrificed erery man taken, and with great difficulty was this disposition now suppressed. Poor Grierson and several others had been killed after surrender; and although the American commandants used every exertion, and offered a large reward to detect the murderers, no discovery could be made. In no part of the South was the war conducted with such asperity as in this quarter. It often sunk into barbarity. 
wounded, and fewer killed. But unhappily among the latter was Major Eaton of North Carolina, who had served only a few weeks with the light corps, and in that short period had endeared himself to his commandant and fellow soldiers by the amiability of his manners. He fell gallantly at the head of his battalion in the moment of victory.

On the banks of the Savannah, south of the lagoon near its flow into the river, was situated a large brick building, the mansion-house of a gentleman who had joined the enemy. Here Lee with his corps took post, while Brigadier Pickens with the militia occupied the woods on the enemy's left. The morning was spent in ascertaining the most eligible mode of approach; to execute which all the requisite tools found at Fort Galphin, with many collected from the neighboring farms, had been brought to camp.

Fort Cornwallis was not far from the Savannah river, the shelter of whose banks afforded a safe route to the troops. It was determined to break ground in this quarter, and to extend our works towards the enemy's left and rear.

Pickens and Lee pressed forward their measures against Fort Cornwallis with zeal and diligence; but not with the wished for celerity, so vigilant and resolute was the active and sagacious officer opposed to them. The condition of several of the wounded taken in the attack on Fort Grierson, called for various comforts not to be found in the American camp, and the principal officer who had been taken, asked permission to procure the requisite supply from Colonel Brown, whom he knew to 
be well provided, and whose disposition to cherish his soldiers he had often experienced. To this application Pickens and Lee answered, that after the ungracious determination to stop all intercourse, announced by the. commandant of Fort Cornwallis, disposed as they were to obey the dictates of humanity, it could not be expected that any consideration could prevail with them again to expose the American flag to contumely. If, however, he thought proper to wait upon Colonel Brown, they would permit him to proceed whenever he pleased, on the faith of his parole, returning immediately after receiving Brown's reply.

This offer was cheerfully accepted, and a letter was prepared on the part of the American commandants, expressing the regret with which they permitted a flag to pass from their camp, though borne by a British officer, after the affrontive treatment experienced upon a late occasion; and assuring the commandant of Fort Cornwallis, that no consideration affecting themselves or their troops would ever have led to such a condescension.

To this letter, Brown returned a very polite answer by the prisoner (whose application was instantly complied with), excusing what had passed by a reference to some previous altercations, which had rendered such a decision necessary on the part of the British commandant, so long as the individual to whom he alluded continued to command, ${ }^{*}$ and whom he really did believe

* The individual meant was Colonel Clarke. Brown and this officer had before a very severe conflict. Clarke was often beating up the British quarters, and striking at the light parties of the enemy, chiefly loyalists, with whom, and the militia, aspirit of hate 
had sent in the flag refused to be received, not knowing or expecting the extraordinary change of force opposed to him which had taken place. Pickens and Lee were very much gratified that, while obeying the claims of humanity, they should have produced a renewal of intercourse, without which the contest drawing to a close could not be terminated but with a painful waste of human life.

The works contiguous to the river had advanced nearly to the desired state, and those which had been subsequently commenced in the rear of the fort began to assume a formidable appearance; yet extreme diffculty occurred in the consummation of the plan adopted by the besiegers, as the surrounding ground presented no swell or hill which would enable them to bring their six pounder to bear upon the enemy. It was determined to resort to the Mayham tower, the effect of which Lee had so happily witnessed at Fort Wattson; and orders were accordingly issued to prepare and bring in timber of such a size as would sustain our only piece of artillery.

Brown heretofore had patiently looked on at our approach, diligently working within his fort, as we discovered by the heaps of fresh dug earth in various directions, but with what view remained unascertained. Seeing that his enemy's works were rapidly advancing, he now determined to interrupt our progress by sallies,

and revenge had succeeded to those noble feelings of humanity and forgiveness which ought ever to actuate the soldier. At length all intercourse between the troops was broken up, and the vanquished lay at the mercy of the victor. 
however hazardous, which he foresaw could alone retard his approaching fate, hoping that in delay he might find safety. On the 28th he fell upon our works in the river quarter at midnight, and by the suddenness and vigor of the onset, drove the guard before him; but the support under Captain Handy coming up, after an obstinate conflict, regained the trenches, and forced the enemy to take shelter in the fort.

The determined spirit manifested by the foe in this attempt to destroy our approaches, induced Lee to appropriate his infantry exclusively for their defence at night, relieving them from any further share in labor and from every other duty. It was divided into two divisions, to one of which was alternately committed the protection of our works. On the succeeding night Brown renewed his attempt in the same quarter, and for a long time the struggle was continued with mutual pertinacity, till at length Captain Rudulph, by a combined charge with the bayonet, cleared the trenches, driving the enemy with loss to his stronghold. On the 30 th, the timber required to build the proposed Mayham tower, was prepared and conveyed to the intended site. In the evening we commenced its erection, under cover of an old house to conceal our object from the enemy. In the course of the night and the ensuing day we had brought our tower nearly on a level with the enemy's parapet, and began to fill its body with fascines, earth, stone, brick, and every other convenient rubbish, to give solidity and strength to the structure. At the same time the adjacent works, in the rear of the fort, were vigorously pushed to the enemy's left, to connect them 
with the tower, which was the point of their termination.

Brown's attention was soon drawn to this quarter; and, penetrating the use to which the log building would be applied, he determined to demolish it without delay.

Pickens and Lee, well assured from what had passed that their judicious opponent would leave nothing unessayed within his power to destroy their tower, - on the completion of which their expectation of immediate success chiefly depended,--determined to prepare before night for the counteraction of any attempt which might be made. The lines in that quarter, entrusted to the militia, were doubly manned; and Handy's division of the infantry, though on duty every other night, was drawn from the river quarter to maintain the militia. The North Carolina battalion supplied its place; and to Captain Handy on one side, and to Captain Rudulph on the other, (approved officers,) were committed henceforward the protection of our lines. The tower was designated as the peculiar object of attention, and to its defence one company of musketry was exclusively applied. Not more than one third of the night had passed when the enemy began to move; concealing his real object by renewing his attempt upon the river quarter, where Rudulph, with his accustomed gallantry, gave him a warm reception.

While the contest here was bravely urged, and as bravely sustained, Lieutenant Colonel Brown with the elite of his garrison fell upon our works in his rear. Here for a while the militia of Pickens contended with 
vigor, but at length were forced by the bayonet out of the trenches. Handy, leaving one company at the tower, with his main body hastened to support the militia, who very gallantly united with the regulars, and turned upon the successful foe.

The conflict became furious; but at length the Marylanders under Handy carried the victory by the point of the bayonet. Upon this occasion the loss on both sides exceeded all which had occurred during the siege. Brown, finding that every effort to destroy our works by open war proved ineffectual, now resorted to stratagem. Lee had omitted to put down,* as was originally intended the old wooden house, under cover of which the tower had been commenced, and which by accidentally taking fire would have probably consumed it. This house attracted Brown's notice, and he determined, by burning it, to rid himself of the tower. He had by this time erected a platform in one of the angles of the fort opposite to our Mayham tower, and which, being mounted with two of his heaviest pieces of ordnance, opened upon it before it was finished.

Nevertheless the exertions of the builders did not slacken, and on the first of June the tower was completed, and was found to overlook the enemy's parapet. The upper logs having been sawed to let in an embrasure for our six pounder, it only remained to make an apron upon which the matrosses could draw up their piece to the floor of the tower.

* This omission resulted from that spirit of procrastination common to man, and was certainly highly reprehensible. Luckily no injury resulted, whereas very great might have ensued. 
This was done in the course of the day, and at dawn on the second our six pounder was mounted, completely commanding the enemy's fort. Finley instantly announced his readiness to act by returning the enemy's cannonade, which had been continued without intermission. Before noon the enemy's two pieces were dismounted from the platform, and all the interior of the fort was raked, excepting the segment nearest to the tower and some other spots sheltered by traverse.

It was now that Lieutenant Colonel Brown determined to put in execution his concerted stratagem. In the course of the night a deserter from the fort was sent to Lieutenant Colonel Lee. He was a Scot, with all the wily sagacity of his country, and a sergeant of the artillery. Upon being questioned upon the effect of our cannonade, and the situation of the enemy, - -he answered, that the strange loghouse lately erected, gave an advantage, which, duly improved, could not fail to force surrender; but that the garrison had not suffered so much as might be presumed; that it was amply supplied with provisions, and was in high spirits.

In the course of the conversation which followed, Lee inquired, in what way could the effect of the cannonade be increased. Very readily, replied the crafty sergeant: that knowing the spot where all the powder in the fort was deposited, with red hot balls from the six pounder, directed properly, the magazine might be blown up. This intelligence was received with delight, and the suggestion of the sergeant seized with avidity, although it would be very difficult to prepare our balls, as we were unprovided with a furnace. 
It was proposed to the sergeant, that he should be sent to the officer commanding our battery, and give his aid to the execution of his suggestion, with assurances of liberal reward in case of success. This proposition was heard with much apparent reluctance, although every disposition to bring the garrison to submission was exhibited by the sergeant, who pretended that Brown had done him many personal injuries in the course of service. But he added, it was impossible for him to put himself in danger of capture, as he well knew he should be executed on a gibbet, if taken.

A good supper was now presented to him, with his grog; which being finished, and being convinced by the arguments of Lee, that his personal safety could not be endangered, as it was not desired or meant that he should take any part in the siege, but merely to attend at the tower to direct the pointing of the piece, he assented; declaring that he entered upon his task with dire apprehensions, and reminding the lieutenant colonel of his promised reward.

Lee instantly put him in care of his adjutant, to be delivered to Captain Finley, with the information communicated, for the purpose of blowing up the enemy's magazine. It was midnight; and Lieutenant Colonel Lee, expecting on the next day to be much engaged, our preparations being nearly completed, retired to rest. Reflecting upon what had passed, and recurring to the character of his adversary, he became much disquieted by the step he had taken, and soon concluded to withdraw the sergeant from the tower. He had not been many minutes with Captain Finley, before an order re- 
manding him was delivered, committing him to the quarter guard.

In the morning we were saluted with a new exhibition, unexpected though not injurious. Between the quarters of Lee and the fort stood four or five deserted houses; some of them near enough to the fort to be used with effect by riflemen from their upper stories. They had often engaged the attention of Pickens and Lee, with a view of applying them, whenever the enemy should be assaulted, to aid in covering their attack. Brown, sallying out before break of day, set fire to all but two of the houses. No attempt was made to disturb the operation, or to extinguish the flames after the enemy had returned; it being deemed improper to hazard our troops in effecting any object not material in its consequence. Of the two left, one was most commodious for the purpose originally contemplated by Pickens and Lee in the hour of assault.

The besiegers being incapable of discovering any reason for the omission to burn the two houses, and especially the one nearest the fort, various were their conjectures as to the cause of sparing them : some leading to the conclusion that they were left purposely, and consequently with the view of injuring the assailant. The fire from the tower continued, and being chiefly directed against the parapet fronting the river, in which quarter the proposed attack would be directed, demonstrated satisfactorily that the hour had arrived to make the decisive appeal. Orders were accordingly issued to prepare for the assault, to take place on the next day at the hour of nine in the forenoon. In the course of the night, a party of the best marksmen 
were selected from Pickens's militia, and sent to one of the houses nearest to the fort.

The officer commanding this detachment, was ordered to arrange his men in the upper story, for the purpose of ascertaining the number which could with ease use their rifles out of the windows, or any other convenient aperture; then to withdraw, and report to the brigadier. It was intended, before daylight, to have directed the occupation of the house by the same officer, with such a force of riflemen as he should report to be sufficient. Handy was ordered to return to the river quarter at the dawn of day, as to his detachment and the legion infantry the main assault would be committed. These, with all the other preparations, being made, the troops continued in their usual stations,-pleased that the time was near which would close with success their severe toils.

About three in the morning of the fourth of June, we were aroused by a violent explosion, which was soon discovered to have shattered the very house intended to be occupied by the rifle party before daybreak. It was severed and thrown into the air thirty or forty feet high, its fragments falling all over the field. This explained, at once, not only the cause of Brown's omitting its destruction, but also communicated the object of the constant digging which had until lately employed the besieged.

Brown pushed a sap to this house, which he presumed would be certainly possessed by the besieger, when ready to strike his last blow; and he concluded, from the evident maturity of our works, and from the noise made by the militia, when sent to the house in the first part of the night, for the purpose of ascertaining the number 
competent to its capacity, that the approaching morning was fixed for the general assault. Not doubting but the house was occupied with the body destined to hold it, he determined to deprive his adversary of every aid from this quarter; hoping, too, by the consternation which the manner of destruction could not fail to excite, to damp the ardor of the troops charged with storming.

Happily he executed his plan too early for its success, or our gallant band would certainly have shared the fate of the house. This fortunate escape excited grateful sensations in the breasts of the two commandants, for the gracious interposition of Providence; and added another testimonial to the many already received, of the penetration and decision which marked the character of their opponent. The hour of nine approached, and the columns for assault were in array, waiting the signal of advance.

Pickens and Lee having determined, as intercourse with the fort was now open, to present to the enemy another opportunity of avoiding the impending blow by capitulation, a flag was despatched on the $3 \mathrm{~d}$ of June, with a joint letter from the American commanders, adapted to the occasion. Lieutenant Colonel Brown, in reply, repeated his determination to defend the post. This resolution could not be maintained; and on the next day an officer, with a flag, proceeded from the fort. The bearer was received at the margin of our trenches, and presented a letter addressed to the two commandants, offering to surrender upon conditions detailed in the communication. Some of these being inadmissible, the offer was rejected, and other propositions made, which 
would be ratified by them, if acceded to by Lieutenant Colonel Brown. This discussion produced the delay of one day, which was gratifying to Brown; it being unpleasant to surrender on the birth-day of his king.

The terms, as altered, were accepted, and eight o'clock in the morning of the fifth was designated for the delivery of the fort, \&c., to Captain Rudulph, appointed on the part of the victors to take possesion of it with its appurtenances. At the appointed hour the British garrison marched out, Lieutenant Colonel Brown having been taken into the care of Captain Armstrong, of the dragoons, with a safe guard to protect his person from threatened violence.* This precaution suggested by our knowledge of the inveteracy with which the operations in this quarter had been conducted on both sides, turned out to be extremely fortunate; as otherwise, in all probability, the laurels acquired by the arms of America would have been stained by the murder of a gallant soldier, who had committed himself to his enemy on their

* This precaution was indispensable. Already had the humanity of the besieging corps been dreadfully outraged by the slaughter of Colonel Grierson and some of his associates. To risk a repetition of the same barbarity, would have justly exposed the commandants to reproach and censure. It was determined to take measures in time to prevent such an issue. Lieutenant Colonel Brown's life was, we knew, sought with avidity; consequently it became our duty to secure his person before the garrison marched out. Brown had himself suffered very cruel and injurious personal treatment in the beginning of the revolution, and succeeding events more and more embittered both himself and the Georgin militia, heretofore his only opponents, till at length in this quarter a war of extermination became the order of the day. 
plighted faith. Brown was conveyed to Lee's quarters, where he continued until the next day, when himself and a few of his officers were paroled, and sent down the river to Savannah, under the care of Captain Armstrong, with a party of infantry, who had orders to continue with Lieutenant Colonel Brown until he should be placed out of danger. During the few hours' residence in Lee's quarters, the British colonel inquired after his artillery sergeant, who had a few nights before deserted from the fort. Upon being told that he was in the quarter guard, he took the first opportunity of soliciting from Lee his restitution, frankly declaring that he was no deserter, but was purposely sent out by him in that character, to destroy by fire the newly erected loghouse, which he plainly discerned to be destructive to his safety, and which his sergeant undertook to do while pretending to direct our fire with the view of blowing up the magazine of the fort.

This communication showed the danger to which the besiegers were exposed for a few minutes, by the readiness with which Lee entered into the plan of the deserter, but which, upon further reflection, he fortunately changed; and demonstrates the great caution with which the offer of aid from deserters ought to be received, especially when coming from a besieged fortress on the point of surrender, and in the care of an experienced, sagacious soldier. The request of Lieutenant Colonel Brown was granted, and his sergeant with joy rejoined his commander. As soon as the capitulation was signed, preparations for decamping were begun, and early the 
next morning, the baggage of the corps under Lee was transported across the Savannah; about noon, the infantry followed; and in the evening of the 6th, Lee joined with his cavalry; proceeding with expedition to Ninety-Six, in obedience to orders from General Greene. Brigadier Pickens remained at Augusta until conveyance for the stores taken there and at Fort Galphin could be provided; which being accomplished in a few days, he also marched for headquarters. Without delay, after the British garrison had laid down their arms, Pickens and Lee despatched intelligence of the event to Greene, who, announcing the success in general orders, was pleased to express to the two commandants, and their respective corps, the high sense he entertained of their merit and service, with his thanks for the zeal and vigor exhibited in the execution of the duty assigned to them. Lee, pressing forward with despatch, reached Ninety-Six on the forenoon of the 8th. Two routes led south of the enemy to the American headquarters, which had been established on the enemy's right. The officer despatched with the garrison of Fort Cornwallis in his charge, mistaking the intended course, took the road nearest to the town, which brought his troops under command of the enemies' batteries for a small distance. Believing that the exhibition was designed with a view to insult the feelings of the garrison, Lieutenant Colonel Cruger gave orders for. the contiguous batteries to open upon this corps, notwithstanding it enveloped his fellow soldiers taken at Augusta, and was very near chastising the supposed bravado, which in fact was only the error 
of the conducting officer. Luckily no injury was sustained; but the officer was very severely reprimanded by Lieutenant Colonel Lee, for the danger to which his inadvertence had exposed the corps. 


\section{CHAPTER X VII.}

Siege of Ninety Six-Kosciusko chief engineer-His blunders-Lee placed in command on the left besieges the stockade-Resisted by continual night sallies-Greene receives intelligence of Lord Rawdon's approach-Orders Marion and Pickens to delay Rawdon and retains Lee with him at Ninety Six-Lee attempts to burn the stockade fort, but fails-Rawdon's messenger reaches CrugerActive operations-Near approach of Lord Rawdon-Greene resolves to storm the fort of Ninety Six-The storming-Lee and Campbell lead the assault-Desperate conflict in the Star FortLee's Legion captures the stockade fort--He is ordered by Greene to hold the stockade-Losses-Retreat ordered-Sad reverseGreene's equanimity.

While Lee and Pickens had been engaged in capturing Augusta, General Greene with the main army of the South had been prosecuting the siege of Ninety-Six. Lieutenant Cruger the commandant at that post was a New York loyalist, an excellent soldier. The garrison numbered 550 men, of whom 350 were regulars, loyal Americans, and the residue were loyal militia of South Carolina led by Colonel King.

On the left of the village of Ninety-Six ran a small rivulet which furnished water to the town and troops. The defences were a stockade fort, a fortified garrison, and the principal work, called, from its form, the Star Fort. 
On commencing the siege General Greene had entrusted the engineering operations to Colonel Kosciusko, the Polish officer who subsequently became so famous, but who on the present occasion showed utter incapacity, and by his blunders caused the failure of the siege.

Neglecting to cut off the enemy's supply of water from the rivulet, he directed his attention wholly to the Star Fort. His first works were promptly demolished by a vigorous sally of the besieged. General Greene now broke ground at a greater distance from the enemy's works, and proceeded with more caution, still marching under Kosciusko's advice, the Star Fort the single object of attack.

As soon as the corps of Lee entered camp, that officer was directed to take post opposite to the enemy's left, and to commence regular approaches against the stockade. Very soon Lee pushed his ditch to the ground designated for the erection of the battery; under the cover of which the subsequent approaches would be made. In the course of the next day this battery was erected, and Lieutenant Finn, with a six pounder, took possession of it. The besiegers advancing closer and cluser with caution and safety, both on the right and left, Lieutenant Colonel Cruger foresaw his inevitable destruction, unless averted by the approach of Lord Rawdon. To give time for the desired event, he determined, by nocturnal sallies, to attempt to carry our trenches; and to destroy with the spade whatever he might gain by the bayonet. These rencontres were fierce and frequent, directed sometimes upon one quarter and sometimes upon another: but so judicious had been the 
arrangements of the American general to counteract these expected attempts, that in no one instance did the British commandant succeed. The mode adopted was nevertheless pursued without intermission; and although failing to effect the chief object contemplated, became extremely harassing to the American army, whose repose during the night was incessantly disturbed, and whose labor in the day was as incessantly pressed.

General Greene, having learned that Lord Rawdon had received a reinforcement from Ireland, was impatient to conclude the siege. He was informed by Sumter on the 11th of June that Rawdon was on the march to relieve Ninety-Six. Greene directed Sumter to keep in Rawdon's front, and ordered Marion and Pickens to assist Sumter in delaying Rawdon's approach to the besieged place; but he retained Lee to aid in the siege.

Our approaches, says Lee,* continued to be pushed with unabated diligence, in the expectation and hope that they might be brought to maturity in time to enforce the submission of the garrison, before the British general could make good his long march.

We now began to deplore the early inattention of the chief engineer to the enemy's left; persuaded that had he been deprived of the use of the rivulet in the beginning of the siege, he must have been forced to surrender before the present hour. It was deemed practicable to set fire to the stockade fort, and thus to remove the water defence to the left of the rivulet. In the succeeding day, a dark violent storm came on from the west, without rain.

* Memoirs. 
Lee proposed to General Greene to permit him to make the attempt. This being granted, a sergeant with nine privates of the legion infantry, furnished with combustible matter, was directed to approach the stockade in the most concealed direction, under cover of the storm, while the batteries in every quarter opened upon the enemy, and demonstrations of striking at the star redoubt were made, with the expectation of diverting his attention from the intrepid party, which, with alacrity, undertook the hazardous enterprise. The sergeant conducted his gallant band in the best manner; concealing it whenever the ground permitted, and when exposed to view moving along upon the belly.

At length he reached the ditch with three others; the whole close behind. Here unluckily he was discovered, while in the act of applying his fire. Himself and five were killed; the remaining four escaped unhurt, although many muskets were discharged at them running through the field, before they got beyond the nearest rise of ground which could cover them from danger. After this disappointment, nothing remained but to force our works to maturity, and to retard the advance of the British army.

In the evening, a countryman was seen riding along our lines south of the town, conversing familiarly with the officers and soldiers on duty. He was not regarded, as from the beginning of the siege our friends in the country were in the habit of visiting camp, and were permitted to go wherever their curiosity led them, one of whom this man was presumed to be. At length he reached the great road leading directly to the town, in 
which quarter were only some batteries thrown up for the protection of the guards. Putting spur to his horse, he rushed with full speed into town, receiving the ineffectual fire of our sentinels and guards nearest to him, and holding up a letter in his hand as soon as he cleared himself of our fire. The propitious signal gave joy to the garrison, who running to meet their friend, opened the gate, welcoming his arrival with loud expressions of joy. He was the bearer of a despatch from Rawdon to Cruger, communicating his arrival at Orangeburgh in adequate force, and informing him that he was hastening to his relief. This intelligence infused new vigor into the intrepid leader and his brave companions.

It also inspired the indefatigable besieger with additional motives to push to conclusion his preparatives, as he now yielded up every hope heretofore derived from Cruger's ignorance of the movement of the British general, and the forwardness of our works. Major Greene, who commanded in the star with great ability, finding that our third parallel was nearly finished, and that a Mayham tower was erecting which would overlook his parapet, very judiciously covered it with sand-bags to lessen the capacity derived from superior height, leaving between each bag an aperture for the use of his riflemen.

Nor were Lee's approaches on the left less forward than those on the right; they not only were directed against the stockade, but also were carried so near the rivulet, as to render supplies of water difficult and precarious. The fire during the 17 th was so effectual, as to induce the enemy to withdraw his guards established 
between the rivulet and the stockade; and parties of the troops on the left were posted in various points, to annoy the communication with the rivulet. These arrangements succeeded throughout the day completely, and the enemy suffered greatly from this privation, though accomplished too late to produce material advantage. Rawdon continued to advance by forced marches, and inclining to his right, made a vigorous push to throw himself between Sumter and Greene.

In this effort he completely succeeded, and thus baffled all the measures adopted by Greene to delay his approach. It became now necessary to hazard assault of the fort, to meet Rawdon, or to retire. The American general was disposed to imitate Cæsar at Alisia ; first to beat the relieving army, and then to take the besieged town. But his regular force did but little exceed the half of that under Rawdon, which added to his militia, consisting of the corps of Sumter, Marion, and Pickens, still left him numerically inferior to the British general. Nevertheless confiding in his known superiority of cavalry, he would have given battle to his lordship, could he have left an adequate corps to attend to the garrison. Compelled to relinquish this plan, he determined to storm the fort, although his works were yet unfinished. On the right, our third parallel was completed, two trenches and a mine were nearly let into the enemy's ditch, and the Mayham tower was finished.

On the left, our trenches were within fifty yards of his ditch; and the battery directed by Lieutenant Finn, gave to the assailant, in his quarter, advantages, which, well supported, ensured success. Greene, anxiously as 
he desired to conclude his severe toils in triumph, was averse to the unequal contest to which he must necessarily expose his faithful troops, and would probably have decided on the safe course, had not his soldiers, with one voice, intreated to be led against the fort.

The American army having witnessed the unconquerable spirit which actuated their general, as well as the unexpected results of former battles, could not brook the idea of abandoning the siege, without one bold attempt to force a surrender. They recollected, with pain and remorse, that by the misbehavior of one regiment at the battle of Guilford, and of another at Hobkirk's Hill, their beloved general had been deprived of his merited laurels; and they supplicated their officers to intreat their commander to give them now an opportunity of obliterating preceding disgrace. This generous ardor could not be resisted by Greene. Orders were issued to prepare for a storm; and the hour of twelve on the next day (18th of June) was appointed for the assailing columns to advance by signal from the centre battery.

Lieutenant Colonel Campbell, of the first Virginia regiment, with a detachment from the Maryland and Virginia brigades, was charged with the attack on the left; and Lieutenant Colonel Lee, with the legion infantry and Kirkwood's Delawares, with that on the right. Lieutenants Duval of Maryland, and Seldon of Virginia, commanded the forlorn hope of Campbell ; and Captain Rudulph, of the legion, that of Lee. Fascines were prepared to fill up the enemy's ditch, long poles with iron hooks were furnished to pull down the sand-bags, 
with every other thing requisite to facilitate the progress of the assailant. At eleven the third parallel was manned, and our sharp shooters took their station in the tower. The first signal was announced from the centre battery, upon which the assailing columns entered the trenches; manifesting delight in the expectation of carrying by their courage the great prize in view.

At the second cannon which was discharged at the hour of twelve, Campbell and Lee rushed to the assault. Cruger, always prepared, received them with his accustomed firmness. The parapets were manned with spike and bayonet, and the riflemen, fixed at the sand-bag apertures, maintained a steady and destructive fire. Duval and Seldon entered the enemy's ditch at different points, and Campbell stood prepared to support them, in the rear of the party furnished with hooks to pull down the sand-bags. This party had also entered the enemy's ditch, and began to apply the hook.

Uncovering the parapet now would have given us victory; and such was the vigorous support afforded by the musketry from the third parallel, from the riflemen in the tower, and from the artillery mounted in battery, that sanguine expectations of this happy issue were universally indulged. The moment the bags in front were pulled down, Campbell would have mounted the parapet, where the struggle could not have been long maintained.

Cruger had prepared an intermediate battery with his three pieces, which he occasionally applied to the right and left. At first it was directed against Lee's left, but 
very soon every piece was applied upon Campbell's right, which was very injurious to his column.

Major Greene commanding in the star redoubt, sensible of the danger to which he was exposed, if the attempted lodgment upon his front curtain succeeded, determined to try the bayonet in his ditch as well as on his parapet. To Captains Campbell and French was committed this bold effort. Entering into the ditch through a sally-port in the rear of the star, they took opposite directions, and soon came in contact, the one with Duval, the other with Seldon.

Here ensued a desperate conflict. The Americans not only fighting with the enemy in front, but with the enemy overhead, sustained gallantly the unequal contest, until Duval and Seldon became disabled by wounds, when they yielded, and were driven back with great loss to the point of entry. The few surviving escaped with the hookmen to our trenches, where yet remained Campbell, the sand-bags not being removed.

On the left the issue was very different. Rudulph gained the enemy's ditch, and followed by the column, soon opened his way into the fort, from which the enemy, giving their last fire, precipitately retreated. Measures were in train on the part of Lee, to follow up his blow by passing the rivulet, entering the town, and forcing the fortified prison, whence the left might have yielded substantial aid to the attack upon the star, by compelling Cruger to struggle for the town, or forcing him with all his troops to take refuge in the star; a situation not long to be held, crowded as he must have been, and destitute of water. The adverse fortune experienced in the 
assault on the right, made the mind of Greene return to his cardinal policy, the preservation of adequate force to keep the field.

Charmed with the courage displayed in his view, and regretting its disadvantageous application, he sent orders to Campbell to draw off, and to Lee to desist from further advance, but to hold the stockade abandoned by the enemy.

Our loss amounted during the siege, to one hundred and eighty-five killed and wounded; that of the garrison to eighty-five. Captain Armstrong, of the Maryland line, was the only officer killed on our side, as was Lieutenant Roney the only one on their side. After our repulse, Greene sent a flag to Lieutenant Colonel Cruger, proposing a cessation of hostilities for the purpose of burying the dead; but as to the burial of the dead the proposition was rejected, Cruger not choosing to admit our participation in a ceremonial which custom" had appropriated to the victor.

As soon as it was dark, the detachment was withdrawn from the stockade, and preparations were begun for retreat.

On the 19th, Greene communicated to Sumter the event of the preceding day, advised him of the route of retreat, and ordered the corps in his front, with the caralry under Washington, to join him with celerity. Taking leave of Mrs. Cruger and Mrs. Greene, and leaving for the protection of the ladies the usual guard,* until

* When General Greene approached Ninety-Six, he found the ladies of Lieutenant Colonel Cruger and Major Greene, in a farm-house in 
Col. Cruger should be advised of his retreat, and take his measures for their security, the American general withdrew, having two days before sent forward his sick and wounded. During the preceding night, gloom and silence pervaded the American camp: every one disapappointed-every one-mortified. Three days more, and Ninety-Six must have fallen; but this short space was unattainable. Rawdon had approached our vicinity with a force not to be resisted, and it only remained to hold the army safe, by resuming that system which adverse fortune had rendered familiar to us. Greene alone preserved his equanimity; and highly pleased by the unshaken courage displayed in the assault, announced his grateful sense of the conduct of the troops, as well during the siege as in the late heroic attack; presaging from the past, the happiest result whenever an opportunity should be presented of contending with the enemy upon equal terms, - to the attainment of which his best exertions would be invariably directed, relying, as he did, upon the same dauntless spirit recently exhibited. Con-

the neighborhood. The American general tranquilized the fears of the ladies, and as they preferred continuing where they were, he not only indulged them, but placed a guard at the house for their protection. The guard was left until Lieutenant Colonel Cruger was ap. prised of our departure, when he sent the guard with his passport to rejoin our army. Some hours after Greene had withdrawn, one of our light parties, absent some days, returned, and passing by the farmhouse, was going directly to our late camp before Ninety-Six, when Mrs. Cruger sending for the officer, communicated what had happened, and instructed him to overtake the retiring general. 
scious as the army was of having done its duty, it derived eonsolation from this exhilarating address, and burying in oblivion the grating repulse, looked forward with the anticipation of soon displaying their courage in a fair and decisive battle. 


\section{CHAPTER XVIII.}

Lord Rawdon arrives at Ninety-Six-Pursues Greene, who retreats -Rawdon returns to Ninety-Six-Greene offers battle which is declined by Rawdon-Greene detaches Sumter, Marion, and Lee to the lower posts-Lee's success at Dorchester-Hampton's success - Sumter approaches Monk's Corner-Retreat of Coates-Lee charges and captures the British rear guard-Affair at Quinby bridge-Retreat of Coates-Separation of the partisan leadersEminent character and services of Lee and his Legion.

ON the morning of the 21st of June, Lord Rawdon arrived at Ninety-Six ; and, on the evening of the same day, marched in quest of the American army. In the preceding operations of the campaign, he had felt the want of cavalry so severely that, while at Monk's corner, and in Charleston, he had formed a corps of one hundred and fifty horse.

Greene, foreseeing that his active adversary would avail himself to the utmost of his superiority, had sent his sick and wounded northward; and, as soon as Rawdon had crossed the Saluda, he retreated towards Virginia. Lord Rawdon pursued him to the Ennore, whence he returned to Ninety-Six.

The retreat ceased with the pursuit. General Greene halted near the cross roads, on the North of Broad river. 
As Rawdon retired, he was followed close by Lee's legion as far as Ninety-Six, at which place he remained but two days. Still retaining the opinion that circumstances required him to contract his posts, he left the principal part of his army, under the command of Lieutenant Colonel Cruger, to protect the loyalists while removing within those limits which were to be maintained by the British forces; and, at the head of less than one thousand men, marched in person towards the Congaree.

Supposing that his adversary intended to preserve the post at Ninety-Six, where the royalists were numerous, and to establish one or two on the Congaree, where provisions were more plentiful than in any other part of the state, Greene determined to interrupt the execution of the plan which he believed to have been formed. Leaving his sick and baggage at Wynnsborough, to be conducted to Camden, he marched with the utmost expedition for Friday's ferry on the Congaree, at which place Lord Rawdon had arrived two days before him. As Greene drew near to his enemy, a detachment from the legion under the command of Captain Eggleston, announced his approach by attacking a foraging party within a mile of the British camp, and bringing off a troop consisting of forty-five men, with their officers and horses. Rawdon retreated the next day to Orangeburg, where he formed a junction with a detachment from Charleston, commanded by Lieutenant Colonel Stuart.

On the Congaree, Greene was reinforced by Sumter and Marion with about one thousand men; and, on the 11th of July, marched towards Orangeburg with the in- 
tention of attacking the British army at that place. He arrived there the next day, but found it so strongly posted as to be unassailable. He offered battle, but prudence restrained him from attacking the enemy in his camp.

At this place, intelligence was received of the evacuation of Ninety-Six, and that Lieutenant Colonel Cruger was marching down to Orangeburg. The north branch of the Edisto, which, for thirty miles, was passable only at the place occupied by Rawdon, interposed an insuperable obstacle to any attempt on Cruger; and Greene thought it most advisable to force the British out of the upper country by threatening their lower posts at Monk's corner, and at Dorchester. Sumter, Marion, and Lee, were detached on this service; and on the same day, Greene moved towards the high hills of Santee, a healthy situation, where he purposed to give some refreshment and repose to his harassed army, and where he hoped to be joined by a few continental troops and militia from North Carolina.

The detachments ordered against the posts in the north-eastern parts of the state, under the command of Sumter, were not so completely successful as their numbers, courage, and enterprise deserved. The several corps took distinct routes, intending to fall on the different posts between Ashley and Cooper rivers at the same time. That at Dorchester was broken up on the approach of Lee, who captured horses, military stores, and baggage to a considerable amount, and obtained some trivial successes over the flying enemy. Lieutenant Colonel Wade Hampton, of the State cavalry, fell in 
with a body of mounted refugees, dispersed the whole, and made forty or fifty prisoners.

Sumter advanced against Monk's corner. This post was defended by Lieutenant Colonel Coates with the 19th British regiment, and a troop of horse. He had taken possession of a brick church at a bridge over Biggin creek, the most northern of the water courses which form the west branch of Cooper river. After passing Biggin, the road to Charleston crosses first Wattoo, and then Quinby creek; neither of which are passable except at the bridges over which the road leads, and at a ferry over Quinby.

On the sixteenth, Sumter approached Monk's corner, but, not supposing himself strong enough to hazard an attack until all his detachments should be collected, sent a party to seize the bridge over Wattoo, and either to hold or destroy it. This party being attacked by a superior force, retired from the bridge without completing its destruction, and without informing Sumter that his orders had not been fully executed.

Marion had joined Sumter. Lee arrived late in the evening, and the resolution was taken to attack Coates early next morning.

In the course of the night he set fire to the church, in order to destroy the stores which were collected in it, and commenced his march to Charleston, by the road east of Cooper. Having repaired the bridge over Wattoo, he met with no obstruction; and proceeded with his infantry on the road leading to Quinby bridge, directed his cavalry to take the road turning to the right, and crossing the creek at the ferry. 
About three next morning, the flames bursting through the roof of the church announced the retreat of the British; and the pursuit was immediately commenced. Sumter was preceded by the legion, supported by the State cavalry. A detachment from this regiment followed the British horse, in the vain hope of overtaking the troop at the ferry, while Lee pursued the infantry. Within a short distance of the bridge, which is eighteen miles from Monk's corner, he perceived the rear guard of the British, consisting of about one hundred men, commanded by Captain Campbell, which the cavalry charged sword in hand. They threw down their arms, and begged for quarter; upon which they were placed under the care of a few militia horsemen, and the American cavalry resumed the pursuit.

They had not proceeded far, when Lee was called to the rear, by information that the prisoners had been ordered to resume their arms. At this critical moment, Armstrong, at the head of the leading section, came in sight of Coates, who having passed the bridge, and loosed the planks, lay, unapprehensive of danger, intending to destroy it as soon as his rear guard should cross the creek. Armstrong, in obedience to orders, given in the expectation that he would overtake Coates before passing the creek, dashed over the bridge on the guard stationed at the opposite end with a howitzer, which he seized. In this operation, his horses threw off some of the loosened planks, and made a chasm, over which the following section, led by Lieutenant Carrington, leaped with difficulty. In doing this some other planks were thrown off, and the horses of the third section refused to 
take the leap. At this time Lee came up, and every effort was made to replace the planks, but without success. The creek was too deep and miry to afford foothold to those who attempted to raise them from the water.

This halt revived the courage of the British soldiers, who returned to the support of their commander, then engaged in an equal conflict with the cavalry who had passed the bridge. These gallant men finding themselves overpowered by numbers, and that their comrades could not support them, pressed over the causeway, and wheeling into the woods, made their escape.

After finding the impracticability of replacing the planks on the bridge, in attempting which, Doctor Irvin, surgeon of the legion cavalry, and several of the troopers were wounded, Lee withdrew from the contest, and moved some distance up the creek, to a ford where he . was soon joined by the infantry of the legion.

Coates then completed the demolition of the bridge, and retired to an adjoining plantation, where he took possession of the dwelling house and out buildings that surrounded it.

As the Americans were obliged to make a considerable circuit, Sumter, who unfortunately left his artillery behind, did not arrive on the ground till three in the afternoon, and at four the house was attacked. The fire was kept up chiefly by Marion's division, from a fence near the house, till evening, when the ammunition was exhausted, and the troops were called off. In the course of the night, it was perceived that the loss had fallen almost entirely on Marion. Great discontent prevailed, 
and many of the men left him. The infection was communicated to Sumter's troops, and there being reason to fear the approach of Lord Rawdon, the enterprise was abandoned. Sumter crossed the Santee; and the legion rejoined the army, then encamped at the high hills of that river.

The intense heat of this sultry season demanded some relaxation from the unremitting toils which the southern army had encountered. From the month of January, it had been engaged in one course of incessant fatigue, and of hardy enterprise. All its powers had been strained, nor had any interval been allowed to refresh and recruit the almost exhausted strength and spirits of the troops.

The continued labors and exertions of all were highly meritorious; but the successful activity of one corps will attract particular attention. Lee's legion, from its structure, was peculiarly adapted to the partisan war of the southern states; and, by being detached against the weaker posts of the enemy, had opportunities for displaying with advantage all the energies it possessed. In that extensive sweep which it made from the Santee to Augusta, which employed from the 15th of April to the 5th of June, this corps, acting in conjunction, first with Marion, afterwards with Pickens, and sometimes alone, had constituted an essential part of the force which carried five British posts, and made upwards of eleven hundred prisoners. Lee, in the performance of these services, displayed a mind of so much fertility of invention and military resource, as to add greatly to his previous reputation as a partisan. 
The whole army had exhibited a degree of activity, courage, and patient suffering, surpassing any expectation that could have been formed of troops composed chiefly of new levies; and its general had manifested great firmness, enterprise, prudence, and skill.*

* Memoirs. 


\section{CHAPTER XIX.}

Vindictive character of the war in the South-Case of Colonel Hayne -Of Colonels Brown and Grierson-General Greene discourages this spirit-Greene reinforced-Lord Rawdon sails for EnglandSucceeded by Colonel Stuart-Greene resolves to attack himStuart retires to Eutaw-Greene follows him-Battle of EutawBritish driven off the field-Take shelter in a brick house-Attack of Lee's Legion on the house-Retire-Misfortune of Colonel Washington's corps-Result of the battle-A British standard and a gold medal voted by Congress to Greene-Stuart retreats to Monk's Corner-Greene retires to the high hills of Santee.

THE suffering sustained in the ardent struggle for the southern states was not confined to the armies. The inhabitants of the country felt all the miseries which are inflicted by war in its most savage form. Being almost equally divided between the two contending parties, reciprocal injuries had gradually sharpened their resentments against each other, and had armed neighbor against neighbor, until it became a war of extermination.

As the parties alternately triumphed, opportunities were alternately given for the exercise of their vindictive passsions. They derived additional virulence from the examples occasionally afforded by the commanders of the British forces. After overcoming Georgia and 
South Carolina, they seem to have considered those states as completely reannexed to the British empire; and they manifested a disposition to treat those as rebels, who had once submitted and again taken up arms, although the temporary ascendancy of the continental troops should have induced the measure.

One of these executions, that of Colonel Hayne, took place on the third of August, while Lord Rawdon* was in Charleston, preparing to sail for Europe. The American army being at this time in possession of great part of the country, the punishment inflicted on this gentleman was taken up very seriously by General Greene, and was near producing a system of retaliation. The British officers, pursuing this policy, are stated to have executed several of the zealous partisans of the revolution who fell into their hands.

These examples had unquestionably some influence in unbridling the revengeful passions of the royalists, and letting loose the spirit of slaughter which was brooding in their bosoms. The disposition to retaliate to the full extent of their power, if not to commit original injury, was equally strong in the opposite party. When Fort Granby surrendered, the militia attached to the legion

* The execution of Colonel Hayne has been generally ascribed to Lord Rawdon, and that gallant nobleman has been censured throughout America for an act which has been universally execrated. A letter addressed by him to the late General Lee, on receiving the memoirs of the southern war, written by that gentleman, which has been published in the "View of the Campaign of 1781 , in the Carolinas, by H. Lee," gives the British view of that transaction, and exonerates Lord Rawdon from all blame. Lieutenant Colonel Balfour commanded, and Lord Rawdon sought to save Colonel Hayne. 
manifested so strong a disposition to break the capitulation, and to murder the most obnoxious among the prisoners who were inhabitants of the country, as to produce a solemn declaration from General Greene, that any man guilty of so atrocious an act should be executed.

When Fort Cornwallis surrendered, as we have seen, no exertions could have saved Colonel Brown, had he not been sent to Savannah protected by a guard of continental troops. Lieutenant Colonel Grierson of the royal militia was shot by unknown marksmen; and, although a reward of one hundred guineas was offered to any person who would inform against the perpetrator of the crime, he could never be discovered. "The whole country," said Greene, in one of his letters, "is one continued scene of blood and slaughter."

Greene was too humane, as well as too judicious, not to discourage this exterminating spirit. Perceiving in it the total destruction of the country, he sought to appease it by restraining the excesses of those who were attached to the American cause.

At the high hills of Santee, the reinforcements expected from North Carolina were received. The American army, counting every person belonging to it, was augmented to two thousand six hundred men; but its effective force did not exceed sixteen hundred.

After the retreat of General Greene from Orangeburg, Lord Rawdon was induced by ill health to avail himself of a permit to return to Great Britain, and the command of the British forces in South Carolina devolved on Lieutenant Colonel Stuart. He again advanced to the Con- 
garee, and encamping near its junction with the Wateree, manifested a determination to establish a permanent post at that place.

Though the two armies were within sixteen miles of each other on a right line, two rivers ran between them which could not be crossed without making a circuit of seventy miles; in consequence of which Lieutenant Col. Stuart felt himself so secure, that his foraging parties were spread over the country. To restrain them, and to protect the inhabitants, General Greene detached Marion towards Combahee ferry, and Washington over the Wateree. Frequent skirmishes ensued, which, from the superior courage and activity of the American cavalry, uniformly terminated in their favor.

Finding that Lieutenant Colonel Stuart designed to maintain his important position on the Congaree, Greene prepared to recommence active operations. Breaking up his camp at the high hills of Santee, he crossed the Wateree near Camden, and marched towards Friday's ferry.

On being informed of his approach, the British army retired to Eutaw, where it was reinforced by a detachment from Charleston. Greene followed by slow and easy marches, for the double purpose of preserving his soldiers from the effects of fatigue under a hot sun, and of giving Marion, who was returning from a critical expedition to the Edisto, time to rejoin him. In the afternoon of the seventh, that officer arrived; and it was determined to attack the British camp next day.

At four in the morning of the eighth, the American army moved from its ground, which was seven miles from Eutaw, in the following order: The legion of Lee, 
and the State troops of South Carolina, formed the advance. The militia moved next, and were followed by the regulars. The cavalry of Washington, and the infantry of Kirkwood, brought up the rear. The artillery moved between the columns.

At eight in the morning, about four miles from the British camp, the van fell in with a body of horse and foot, who were escorting an unarmed foraging party, and a brisk action ensued. The British were instantly routed. The cavalry made their escape at the sight of the legion dragoons, and the infantry were killed or taken. About forty, including their captain,'were made prisoners. The foraging party which followed in the rear saved themselves by flight, on hearing the first musket. Supposing this party to be the van of the English, Greene arranged his army in order of battle.

The militia, commanded by Generals Marion and Pickens, composed the first line. The second was formed of the continental infantry. The North Carolina brigade, commanded by General Sumner, was placed on the right; the Virginians, commanded by Lieutenant Col. Campbell, formed the centre; and the Marylanders, commanded by Colonel Williams, the left. The legion of ILee was to cover the right flank; the State troops of South Carolina, commanded by Colonel Henderson, the left; and the cavalry of Washington, with the infantry of Kirkwood, formed the reserve. Captain Lieutenant Gaines, with two three-pounders, was attached to the first line; and Captain Brown, with two sixes, to the second.

The British line also was immediately formed. It 
was drawn up across the road, in an oblique direction, in a wood, on the heights near the Eutaw springs, having its right flank on Eutaw creek. This flank was also covered by a battalion commanded by Major Majoribanks which was posted in a thicket, in a line forming an obtuse angle with the main body. The left flank was protected by the cavalry commanded by Major Coffin, and by a body of infantry held in reserve. A detachment of infantry was pushed forward about a mile, with a field piece to employ the Americans until his arrangements should be completed.

The American van continuing to move forward, encountered the British advanced party; upon which Captain Lieutenant Gaines came up with his field pieces, which opened upon the enemy with considerable effect. General Greene also ordered up his first line with directions to move on briskly, and to advance as they fired. As this line came into action, the legion formed on its right flank, and the State troops of South Carolina on its left.

The British advanced party was soon driven in ; and the Americans, continuing to press forward, were engaged with the main body. Lieutenant Colonel Stuart, perceiving the materials of which this line was composed, and probably anticipating its speedy discomfiture, to avoid exposing his flanks to the American cavalry, had directed his troops not to change their position. His design was to meet the American regular's without any alteration of the arrangement originally made. But the militia, many of whom had frequently faced an enemy, being commanded by generals of experience and courage, 
exhibited a degree of firmness not common to that species of force, and maintained their ground with unexpected obstinacy. In the ardor of action, the order not to advance was disregarded, and the British pressed forward as the militia retired. The artillery which was placed in the road was well served on both sides, and did great execution till both the three-pounders commanded by Captain Lieutenant Gaines were dismounted. About the same time, one of the British shared the same fate.

When the militia gave way, Lee and Henderson still maintained the engagement on the flanks. General Sumner was ordered up to fill the place from which Marion and Pickens were receding; and his brigade, ranging itself with the legion infantry, and the State regiment of South Carolina, came into action with great intrepidity. The British, who had advanced upon the militia, fell back to their first ground, upon which Stuart ordered the corps of infantry posted in the rear of his left wing into the line, and directed Major Coffin with his cavalry to guard that flank. About this time Henderson received a wound which disabled him from keeping the field, and the command of his corps devolved on Lieutenant Colonel Hampton.

After sustaining the fire of the enemy with considerable resolution, Sumner's brigade began to give way, and the British rushed forward in some disorder. Greene then directed Williams and Campbell to charge. with the bayonet, and at the same time ordered Washington to bring up the reserve, and to act on his left. Williams charged without firing a musket; but the soldiers of 
Campbell's regiment, being chiefly new levies, returned the fire of the enemy as they advanced. In this critical moment, Lee, perceiving that the American right extended beyond the British left, ordered Captain Rudulph, of the legion infantry, to turn their flank and give them a raking fire. This order was instantly executed with precision and effect. Charged thus both in front and flank, the British broke successively on the left, till the example was followed by all that part of the line. The Marylanders under Williams, had already used the bayonet, and before the troops opposed to them gave way, several had fallen on both sides, transfixed with that weapon.

The British left, when driven off the field, retreated through their encampment towards Eutaw creek, near which stood a three story brick house, surrounded with offices, and connected with a strongly enclosed garden, into which Major Sheridan, in pursuance of orders previously given by Lieutenant Colonel Stuart, threw himself with the New York volunteers. The Americans pursued them closely, and took three hundred prisoners and two pieces of cannon.

Unfortunately for their hopes of victory, the refreshments found in camp furnished a temptation too strong to be resisted; and many of the soldiers left their ranks, and, under cover of the tents, seized the spirits and food within their view. The infantry of Lee's legion, however, pressed the rear so closely as to make a serious struggle to enter the house with the British. The door was forcibly shut in their faces, and several British officers and men were excluded. These were made pri- 
soners, and mixed with the Americans, so as to save them from the fire of the house while retiring from it.

As the British left gave way, Washington was directed to charge their right. He advanced with his accustomed impetuosity, but found it impossible, with cavalry, to penetrate the thicket occupied by Majoribanks. Perceiving an interval between the British right and the creek, he determined to pass through it round their flank and to charge them in the rear. In making the attempt, he received a fire which did immense execution.

The British occupied a thicket almost impervious to horse. In attempting to force it, Lieutenant Stuart who commanded the leading section was badly wounded, his horse killed under him, and every man in his section killed or wounded. Captain Watts, the second in command fell pierced with two balls. Colonel Washington was wounded, and his horse was killed. They fell together; and, before he could extricate himself, he was made a prisoner.

After nearly all the officers, and a large portion of the men were killed or wounded, the residue of the corps was drawn off by Captain Parsons, assisted by Lieutenant Gordon. Soon after the repulse of Washington, Lieutenant Colonel Hampton and Captain Kirkwood with his infantry, came up and renewed the attack on Majoribanks. Great efforts were made to dislodge him, but they were ineffectual. Finding it impracticable to employ horse to advantage on that ground, Hampton drew off his troops and retired to the road.

The corps commanded by Sheridan kept up a contin- 
ual and destructive fire from the house in which they had taken shelter; and Greene ordered up the artillery to batter it. The guns were too light to make a breach in the walls, and, having been brought within the range of the fire from the house, almost every artillerist was killed, and the pieces were abandoned.

The firm stand made by Majoribanks, and the disorder which had taken place among a part of the Americans, gave Stuart an opportunity of rallying his broken regiments, and bringing them again into action. They were formed between the thicket occupied by Majoribanks, and the house in possession of Sheridan.

Major Coffin, who had repulsed the legion cavalry about the time the British infantry was driven off the field, still maintained a formidable position on their left; and no exertions could dislodge Majoribanks or Sheridan from the cover under which they fought. Perceiving that the contest was maintained on ground, and under circumstances extremely disadvantageous to the Americans, Greene withdrew them a small distance, and formed them again in the wood in which the battle had been fought. Thinking it unadvisable to renew the desperate attempt which had just failed, he collected his wounded, and retired with his prisoners to the ground from which he had marched in the morning, determined again to fight the British army when it should retreat from the Eutaws.

Every corps engaged in this hard fought battle reseived the applause of the general. Almost every officer whose situation enabled him to attract notice was named with distinction. "Never," he said; "was artillery 
petter served;" but, "he thought himself principally indebted for the victory he had gained, to the free use made of the bayonet by the Virginians and Marylanders, and by the infantry of Lee's legion and of Kirkwood." To Colonel Williams he acknowledged himself to be particularly indebted. He gave that praise too to the valor of his enemy which it merited. "They really fought," he said, "with courage worthy a better cause."

The loss on both sides bore a great proportion to the numbers engaged. That of the Americans was five hundred and fifty-five, including sixty officers. One hundred and thirty were killed on the spot. Seventeen commissioned officers were killed, and four mortally wounded. "This loss of officers," said their general, " is still more heavy on account of their value than their numbers."

Among the slain was Lieutenant Colonel Campbell, who received a mortal wound while leading the Virginia brigade to that bold and decisive charge which broke the adverse line.

The loss of the British army was stated by themselves at six hundred and ninety-three men, of whom only eighty-five were killed in the field. If this statement be correct, * the American dead greatly exceeded that of the adversary, which was probably the fact, as the carnage of the former, during their unavailing efforts to dislodge the latter from the house and strong adjoining ground, was immense.

* The British accounts acknowledge only two hundred and fifty-seven missing ; but General Greene, in his letter of the 11th of September, says, that including seventy wounded who were left at Eutaw, he made five hundred prisoners. 
Each party had pretensions to the victory, and each claimed the merit of having gained it with inferior numbers. The truth probably is that their numbers were nearly equal.

Nor can the claim of either to the victory be pronounced unequivocal. Unconnected with its consequences, the fortune of the day was nearly balanced. But if the consequences be taken into the account, the victory unquestionably belonged to Greene. The result of this, as of the two preceding battles fought by him in the Carolinas, was the expulsion of the hostile army from the territory which was the immediate object of contest.

Four six-pounders, two of which had been taken in the early part of the day, were brought to play upon the house, and, being pushed so near as to be within the command of its fire, were unavoidably abandoned; but a three-pounder which had been also taken, was brought off by Captain Lieutenant Gaines, whose conduct was mentioned with distinction by General Greene. Thus the trophies of victory were divided.

The thanks of congress were voted to every corps in the army; and a resolution was passed for "presenting to Major General Greene," as an honorable testimony of his merit, a British standard, and a golden medal, emblematic of the battle and of his victory."

On the day succeeding the action, Lieutenant Colonel Stuart marched from Eutaw to meet Major M'Arthur, who was conducting a body of troops from Charleston. The junction was effected about fourteen miles from Eutaw ; and this movement saved $\mathbf{M}^{\top}$ Arthur from Marion 
and Lee, who had been detached on the morning of the same day to intercept any reinforcement which might be coming from below. Stuart continued his retreat to Monk's corner, to which place he was followed by Greene, who, on finding that the numbers and position of the British army were such as to render an attack unadvisable, returned to the high hills of Santee.

The ravages of disease were added to the loss sustained in battle, and the army remained for some time in too feeble a condition for active enterprise.*

On the fourth of January, General St. Clair, who conducted the reinforcement from the north, arrived in camp, and, five days afterward, General Wayne, $\uparrow$ with his brigade, and the remnant of the third regiment of dragoons, commanded by Colonel White, was detached over the Savannah for the recovery of Georgia.

General Greene crossed the Edisto and took post six miles in advance of Jacksonborough, on the road leading to Charleston, for the purpose of covering the state legislature, which assembled at that place on the eighteenth.

* Marshall.

$\dagger$ In the judicious orders given to Wayne, Greene endeavored to jmpress on that officer the importance of a course of conduct, always observed by himself, which might tend to conciliate parties. "Try," says he, "by every means in your power, to soften the malignity and dreadful resentments subsisting between the Whig and 'Tory ; and put a stop as much as possible to that cruel custom of putting men to death after they surrender themselves prisoners. The practice of plundering you will endeavor to check as much as possible; and point out to the militia the ruinous consequences of the policy. Let your discipline be as regular and as rigid as the nature and constitution of your troops will admit." -2 Johnson, 277. 
Thus was civil government re-established in South Carolina, and that state restored to the union.

It is impossible to review this active and interesting campaign without feeling that much is due to General Greene; and that he amply justified the favorable opinion of the Commander-in-chief. He found the country completely conquered, and defended by a regular army estimated at four thousand men. The inhabitants were so divided, as to leave it doubtful to which side the majority was attached. At no time did the effective continental force which he could bring into the field, amount to two thousand men; and of these a considerable part were raw troops. Yet he could keep the field without being forced into action; and by a course of judicious movements, and of hardy enterprise, in which invincible constancy was displayed, and in which courage was happily tempered with prudence, he recovered the southern states. It is a singular fact, well worthy of notice, which marks impressively the soundness of his judgment, that although he never gained a decisive victory, he obtained, to a considerable extent, even when defeated, the object for which he fought.

A just portion of the praise deserved by these achievements, is unquestionably due to the troops he commanded. These real patriots bore every hardship and privation*

* The distresses of the southern army were' snch that, if plainly described, truth would wear the appearance of fiction. They were almost naked and barefooted, frequently without food, and always without pay. That he might relieve them when in the last extremity, without diminishing the exertions of their general to derive support from other sources, by creating an opinion that supplies could be drawn from him, Mr. Morris, as was stated by himself in conversation with the 
with a degree of patience and constancy which can not be sufficiently admired. And never was a general better supported by his inferior officers. Not shackled by men, who, without merit, held stations of high rank obtained by political influence, he commanded young men of equal spirit and intelligence, formed under the eye of Washington, and trained in the school furnished in the severe service of the north, to all the hardships and dangers of war.

author, employed an agent to attend the southern army as a volunteer, whose powers were unknown to General Greene. This agent was instructed to watch its situation; and, whenever it appeared impossible for the general to extricate himself from his embarrassments, to furuish him, on his pledging the public faith for repayment, with a draught on the financier for such a sum as would relieve the urgency of the moment. Thus was Greene occasionally rescued from impending ruin by aids which appeared providential, and for which he could not account. 


\section{CHAPTER XX.}

Lee is sent to headquarters-Witnesses the surrender of CornwallisReturns to General Greene with despatches from WashingtonWayne's operations in Georgia-Contests with the Indians-Final reconquest of Georgia-Wayne rejoins Greene-Greene's operations in South Carolina-Final reconquest of South Carolina-Death of Colonel Laurens-Lee's attempt on St. John's Island-He obtains leave of absence, and returns to Virginia.

Immediateli after the battle of Eutaw, Lee was sent with despatches from General Greene to Washington's headquarters at Yorktown, the siege of which place was terminated by the surrender of Lord Cornwallis, soon after Lee's arrival in camp. Lee tells us in his "Memoirs" that he was present at the surrender. The object of Lee's mission was to gain the assistance of the French fleet in the operations of General Greene in the South. As soon as it was ascertained that the Count Le Grasse would not take under convoy the troops destined to reinforce the southern army, and would not assist in the recovery of Charleston, he was directed to return with the despatches of the Commander-in-chief.

After his return, the war in the South was actively carried on. General Wayne was detached from the main army to recover the State of Georgia, in which the British still held some posts. 
When General Wayne entered Georgia, the British troops in that State retired to the town of Savannah; and the Americans advanced to Ebenezer. Though inferior to their enemy in numbers, they interrupted his communications with the country, and even burned some magazines which had been collected and deposited under the protection of his guns.

Not receiving the aids from the militia which he had expected, Wayne pressed Greene for reinforcements, which that officer was unable to furnish, until Lieutenant Colonel Posey arrived from Virginia with about two hundred men. He proceeded immediately to Georgia, and reached the camp at Ebenezer on the 1st of April.

These troops, though new levies, were veteran soldiers, who, having served the times for which they enlisted, had become the substitutes of men who were designated, by lot, for tours of duty they were unwilling to perform. Being commanded by old officers of approved courage and experience, the utmost confidence was to be placed in them; and Wayne, though still inferior to his enemy in numbers, sought for opportunities to employ them.

The Indians, who occupied the southern and western parts of Georgia, were in the habit of assembling annually at Augusta, for the purpose of receiving those presents which were indispensable to the preservation of British influence over them. The usual time for holding these meetings was arrived; but the Americans being in passession of Augusta, it was necessary to transfer them to a British post, and the Indians were invited to keep down the south side of the Altamaha to its mouth, 
whence they were to be conveyed through the inland passage to Savannah. Arrangements had been made for bringing a strong party of Creeks and Choctaws, assembled on the south side of Altamaha, to Harris's bridge, on the Ogechee, about seven miles from that town, and Colonel Brown marched at the head of a strong detachment to convoy them into it. The Indians having quarrelled, instead of proceeding to Ogechee, returned home, and Brown marched back his detachment.

Wayne received intelligence of this movement, and, determined to avail himself of the opportunity given by this division of his enemy to fight him in detail, immediately put his army in motion. He was soon informed that Brown was on his return, and would reach Savannah that night. Disregarding the danger of throwing himself with inferior numbers between the two divisions of the British army, he determined on hazarding an action, and his advance, consisting of a troop of Virginia cavalry, commanded by Captain Hughes and Lieutenant Boyer, and a light company of Virginia infantry, commanded by Captain Parker, entered the road along which Brown was marching, about twelve at night, just as his front appeared in view. A vigorous charge was instantly made, which, being entirely unexpected, was completely successful. The British, struck with a panic, dispersed among the thickets and fled in all directions. Colonel Douglass and about forty men were killed, wounded, or taken. The American loss was five men killed and two wounded. The next day, after parading 
in view of Savannah, Wayne resumed his position at Ebenezer.

The resolution of Parliament against the farther prosecution of active war in America was followed by instructions to the officers commanding the armies of Britain, in consequence of which, propositions for the suspension of hostilities were made in the southern department, about the time that they were rejected in the north. The same motives continuing to influence congress, they were rejected in the south also, and the armies still continued to watch each other with vigilance.

To avoid surprise, Wayne frequently changed his ground, and was continually on the alert. While his whole attention was directed towards Savannah, an enemy entirely unlooked for came upon his rear, entered his camp in the night, and, had not his army been composed of the best materials, must have dispersed it.

A strong party of Creeks, led by a gallant warrior, Emistasigo, or Guristersego, instead of moving down on the south side of the Altamaha, passed through the centre of Georgia with the determination of engaging the American posts. Marching entirely in the night, through unfrequented ways, subsisting on meal made of parched corn, and guided by white men, they reached the neighborhood of the American army then encamped at Gibbon's plantation, near Savannah, without being perceived, and made arrangements to attack it. In the night they emerged from the deep swamp in which they had been concealed, and, approaching the rear of the American camp with the utmost secrecy, reached it about three in the morning. The sentinel was killed 
before he courd sound the alarm, and the first notice was given by the fire and the yell of the enemy. The Indians rushed into camp, and killing the few men they fell in with, seized the artillery. Fortunately some time was wasted in the attempt to turn the pieces on the Americans. Captain Parker, who commanded the light company, had been employed on a very fatiguing tour of duty near Savannah, and had returned that evening to camp. To allow his harassed soldiers some repose, he was placed in the rear near the artillery, and was asleep when the Indians entered the camp. Roused by the fire, and perceiving that the enemy was amidst them, he judiciously drew off his men in silence, and formed them with the quarter guard behind the house in which the general was quartered. Wayne was instantly on horseback, and believing the whole garrison from Savannah to be upon him, determined to repulse the enemy or die in the attempt. Parker was directed to charge immediately with the bayonet, and orders were despatched to Posey, the commanding officer in camp, to bring up the troops without delay. The orders to Parker were so promptly executed, that Posey, although he moved with the utmost celerity, could not reach the scene of action in time to join in it. The light troops and quarter guard under Parker, drove everything before them at the point of the bayonet. The Indians, unable to resist the bayonet, soon fled, leaving their chief, his white guides, and seventeen of his warriors dead upon the spot. Wayne, who accompanied his light troops, now first discovered the character of his enemy, and adapted his pursuit to it. Yet only twelve prison- 
ers were made: The general's horse was shot under him, and twelve privates were killed and wounded.*

This sharp conflict terminated the war in Georgia. Information was soon given of the determination to withdraw the British troops from Savannah; and arrangements being made, with the sanction of the civil government, for the security of such individuals as might remain in town, the place was evacuated. The regular troops retired to Charleston, and Colonel Brown conducted his loyalists through the islands into Florida. Wayne was directed to rejoin General Greene.

In South Carolina the American army maintained its position in front of Jacksonborough, and that of the British was confined to Charleston and its immediate vicinity. The situation of the ground as well as the condition of his army, was unfavorable to offensive operations on the part of General Greene; and General Leslie, who commanded in Charleston, was not strong enough to attempt the recovery of the lower country. While the two armies continued to watch each other, occasional enterprises were undertaken by detachments, in some of which a considerable degree of merit was displayed. In one of them, the corps of Marion, its general being attending in the legislature, was surprised and dispersed by the British Colonel Thompson; and in another, an English guard galley, mounting twelve guns, and manned with forty-three seamen, was captured by Captain Rudulph of the legion.

* In addition to the public documents and accounts the author received a statement of this action in a letter from his friend Captain Parker. 
From the possession of the lower country of South Carolina, which was known to contain considerable quantities of rice and beef cattle, the army had anticipated more regular and more abundant supplies of food than it had been accustomed to receive. This hope was disappointed by the measures of the government.

The generals, and other agents acting under the authority of Congress, had been accustomed in extreme cases, which too frequently occurred, to seize provisions for the use of the armies. This questionable power had been exercised with forbearance, most commonly in concert with the government of the state, and under the pressure of such obvious necessity as carried its justification with it.

The war being transferred to the South at a time when the depreciation of paper money had deprived congress of its only fund, it became indispensably necessary to resort more generally to coercive means in order to procure subsistence for the troops. Popular discontent was the natural consequence of this odious measure, and the feelings of the people were communicated to their representatives. After the termination of the very active campaign of 1781 in Virginia, the legislature of that state passed a law prohibiting all impressment, "unless it be by warrant from the executive in time of actual invasion;" and the assembly of South Carolina, during the session at Jacksonborough, also passed a law forbidding impressment, and enacting, "that no other persons than those who shall be appointed by the governor for that purpose, shall be allowed or permitted to procure supplies for the army." 
The effect of this measure was soon felt. The exertions of the agent appointed by the governor failed to procure subsistence for the troops, and General Greene, after a long course of suffering, was compelled to relieve his urgent wants by an occasional recurrence to means forbidden by the law.

Privations, which had been borne without a murmur under the excitement of active military operations, produced great irritation during the leisure which prevailed after the enemy had alondoned the open field; and, in the Pennsylvania line, which was composed chiefly of foreigners, the discontent was aggravated to such a point as to produce a treasonable intercourse with the enemy, in which a plot is understood to have been laid for seizing General Greene and delivering him to a detachment of British troops, which would move out of Charleston for the purpose of favoring the execution of the design. It was discovered when it is supposed to have been on the point of execution; and a Sergeant Cornell, believed to be the chief of the conspiracy, was condemned to death by a court martial, and executed on the 22nd of April. Some others, among whom were two domestics of the general's family, were brought before the court on suspicion of being concerned in the plot, but the testimony was not sufficient to convict them; and twelve deserted the night after it was discovered. There is no reason to believe that the actual guilt of this transaction extended farther.

Charleston was held until the 14th of December. Previous to its evacuation, General Leslie had proposed 
a cessation of hostilities, and that his troops might be supplied with fresh provisions, in exchange for articles of the last necessity in the American camp. The policy of government being adverse to this proposition, General Greene was under the necessity of refusing his assent to it, and the British general continued to supply his wants by force. This produced several skirmishes with foraging parties, to one of which importance was given by the death of Lieutenant Colonel Laurens, whose loss was universally lamented.

This gallant and accomplished young gentleman had entered into the family of the Commander-in-chief at an early period of the war, and had always shared a large portion of his esteem. Brave to excess, he sought every occasion to render service to his country, and to acquire that military fame which he pursued with the ardor of a young soldier, whose courage seems to have partaken largely of that romantic spirit which youth and enthusiasm produce in a fearless mind. No small addition to the regrets occasioned by this loss was derived from the reflection that he fell unnecessarily, in an unimportant skirmish, in the last moments of the war, when his rash exposure to the danger which proved fatal to him could no longer be useful to his country.

During these last operations in the southern war, Lee took as usual an active part, and on one occasasion was near accomplishing a brilliant feat by surprising a British force stationed on St. John's Island in the Ashely river. But the night was so excessively dark, that after landing on the island, the two divisions of the attacking 
force became separated, and the attempt was necessarily abandoned. Soon after this affair, Lee, having become incapable from ill health of continuing in command of the light troops, obtained leave of absence and returned to his home in Virginia. 


\section{CHAPTER XXI.}

Colonel Lee's marriage-Neglect of his services by Congress-Favorable opinion entertained of him by Greene and Washington-His important services-Lee elected a member of the Continental Congress-His correspondence with Washington-Death of General Greene.

Soow after Lieutenant Colonel Lee's return to Virginia, he married Miss Matilda, the daughter of Philip Ludwell Lee, and settled at Strafford, the residence of his father-in-law, in the county of Westmoreland. A season of repose had become indispensable; for Lee had suffered greatly under the unceasing activity of body and mind to which he had been subjected during his recent campaigns in the South.

It is said that at the time of his quitting the army, Lieutenant Colonel Lee thought himself neglected, and his services underrated. Whether he entertained such an opinion or not, the fact is unquestionable that his rank at the time of his leaving the army was by no means so high as it should have been. The neglect of his remarkable merits and services is one of the numerous acts of injustice which are chargeable on the Continental Congress, who elevated to the rank of brigadier, and even major general, many officers who had 
not a tithe of his ability as a commander, and had not rendered to the country a hundredth part of the services which had been performed by Lee.

Washington always did him justice, and remained, as we shall see, his attached and zealous friend as long as he lived. Greene also well understood his merit, and a reciprocal esteem and friendship bound them firmly together. So highly did Greene appreciate Lee's achievements while under his command, that he declared without reserve, that "his services had been greater than those of any one man attached to the southern army."

It is really trying to the patience of the reader of American history to find in our list of the generals of the revolutionary army, a number of men of whom scarcely anything is known but that they were generals; while Lee, whose brilliant exploits are traced through the whole history of the war, from ' 77 to its close, and who captured fort after fort from New York to Georgia, is permitted to retire from the army with the same rank which he held just after the long series of victories commenced, that of Lieutenant Colonel. It is much to his credit that he did not retire from the army till the great work was accomplished, and there was no more serious fighting to be done.

In the year 1786, Lee was elected a member of Congress from Virginia, and he remained in this high, responsible, but by no means agreeable office until the adoption of the Federal Constitution. During this period, Congress was not what it had been in the early days of the revolution. The master spirits of the nation had generally withdrawn from its legislative councils 
and the people, disgusted by the imbecility of their successors, paid little attention to its acts. But Lee addressed himself to his new duties with his accustomed ardor and patriotism. His correspondence with Washington at this period shows that he still retained the confidence of the Father of his country, who freely interchanged opinions with him on public affairs.

By the following extract from a letter from Colonel Lee to General Washington respecting the grand topic of the day, the free navigation of the Mississippi, it would appear that Lee was a believer in the doctrine that a representative must yield his own judgment to the instructions of his constituents. Lee says :

"The eastern States consider a commercial connection with Spain as the only remedy for the distresses, which oppress their citizens, most of which they say flow from the decay of their commerce. Their delegates have consequently zealously pressed the formation of this connection, as the only effectual mode to revive the trade of their country. In this opinion they have been joined by two of the middle States. On the other hand, Virginia has with equal zeal opposed the connection, because the project involves expressly the disuse of the navigation of the Mississippi for a given time, and eventually they think will sacrifice our right to it. The delegation is under instructions from the State on this subject. They have acted in obedience to their instructions, and, myself excepted, in conformity to their private sentiments. I confess that $I$ am by no means convinced of the justice or policy of our instructions, and very much apprehend, unless they are repealed by the 
present Assembly, the fatal effects of discord in council will be experienced by the United States in a very high degree.

"With respect to the navigation of the Mississippi, you already know my sentiments. They have been uniformly the same, and, as I have observed to you in a former letter, are controverted by only one consideration of weight, and that is, the operation which the occlusion of it may have on the minds of the western settlers, who will not consider the subject in a relative point of view, or on a comprehensive scale, and may be influenced by the demagogues of the country to acts of extravagance and desperation, under the popular declamation, that their interests are sacrificed. Colonel Mason at present is in a fit of the gout. What his sentiments on the subject are, I know not, nor whether he will be able to attend the Assembly during the present session. For some reasons, however, which need not be mentioned, I am inclined to believe he will advocate the navigation of that river. But in all matters of great national moment, the only true line of conduct is dispassionately ti: compare the advantages and disadvantages of the measure proposed, and decide from the balance. The less evil, where there is a choice of them, should always yield to the greater. What benefits, more than we now enjoy, are to be obtained by such a treaty with Spain, as you have delineated, I am not enough of a commercial man to give my opinion on."

A few months before this correspondence General Greene died after a short illness near Savannah, Georgia, (June 19th, 1786,) aged forty-four, leaving a name 
that will ever shine with pre-eminent lustre in the snnals of the country.

"Your friend and second," said Mr. Lee in his letter to Washington, "the patriot and noble Greene is no more. Universal grief reigns here. How hard is the fate of the United States to lose such a son in the middle of life! Irreparable loss! But he is gone, and I am incapable to say more."-July 11th. Congress voted, that $n$ monument should be erected at the seat of governmont, s" in leonor of his patriotism, valor, and

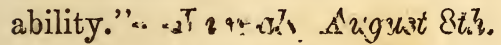




\section{HAPTER XXII.}

Correspondence of Colonel Lee and General Washington on the subject of the latter accepting the office of President of the United States.

After the adoption of the Federal Constitution, it was referred to Congress to pass the acts necessary for carrying it into execution. Colonel Lee, being at this time a member of Congress, was able to appreciate all the difficulties which would attend the new government at its outset; and was strongly impressed with the absolute necessity of General Washington being placed at its head as President of the United States. At the same time he knew Washington's reluctance to enter public life again. With the cordial familiarity of an old friend, he wrote to Washington as follows:

HENRY LEE TO GEORGE WASHINGTON.

\section{New YoRk, 13 September, 1788.}

Mr dear General, -At length the new government has received the last act necessary to its existence. This day Congress passed the requisite previous arrrangements. The first Wednesday in January the ratifying States are to appoint electors; on the first Wednesday in February the President is to be chosen; and the first 
Wednesday in March is the time, and this city the place, for commencing proceedings.

Some delay has attended this business from a difference in opinion respecting the place of meeting, but this delay has not in the least affected the sooner or later operation of the constitution. The southern gentlemen did not accord in the place of temporary residence, from a discordance in sentiment of its effect on the establishment of the permanent seat of government. Some considered this city, others a more southern position, as the most favorable theatre to negotiate the determination of the ten miles square. Many plausible and some cogent reasons are adducible in support of either opinion, and time only can show which is founded in propriety.

The solemnity of the moment, and its application to yourself, has fixed my mind in contemplations of a public and a personal nature; and I feel an involuntary impulse, which I carnot resist, of communicating without reserve to you some of the reflections which the hour has produced. Solicitous for our common happiness as a people, and convinced, as I continue to be, that our peace and prosperity depend on the proper improvement of the present period, my anxiety is extreme that the new government may have an auspicious beginning. To effect this, and to perpetuate a nation formed under your auspices, it is certain that again you will be called forth.

The same principles of devotion to the good of mankind, which have invariably governed your conduct, will, no doubt, continue to rule your mind, however opposite their consequences may be to your repose and happiness. It may be wrong, but I cannot suppress, in my wishes 
for national felicity, due regard to your personal fame and content.

If the same success should attend your efforts on this important occasion, which has distinguished you hitherto, then to be sure you will have spent a life, which Providence rarely, if ever, gave to the lot of one man. It is my belief, it is my anxious hope, that this will be the case, but all things are uncertain, and perhaps nothing more than political events. The new government, though about to commence its proceedings, and received by a large majority of the people with unprecedented unanimity and attachment, must encounter, from the nature of human affairs, many difficulties. These obstacles to its harmonious progress will receive additional weight and influence from the active and enterprising characters, who continue to inflame the passions and to systematize the measures of opposition. The circular letter from this State seems to be the standard to which the various minorities will repair, and, if they should succeed in bringing quickly into action the objects of that letter, new and serious difficulties must arise, which will cross and may destroy the government in its infancy.

Much will depend on the part which the Assembly of Virginia may adopt in this business, and from the complexion of that body, little is to be hoped. They appear to be generally opposed, and Mr. Henry with many other conventional coadjutors are members of the legislature. Madison will not be there, nor is there a friend to government in the Assembly of comparative ability. It would be fortunate if this gentleman could be introduced into that body, and I think it is practic- 
able. Mr. Gordon, one of the Orange members, would readily vacate to let him in, and the county would certainly elect him. In my letter of this date to Dr. Stuart I have mentioned this suggestion.

It would certainly be unpleasant to you, and obnoxious to all who feel for your past fame, to see you at the head of a tumbling system. It is a sacrifice on your part, insupportable in any point of view. But, on the other hand, no alternative seems to be presented. Without you the government can have but little chance of success, and the people of that happiness which its prosperity must yield. In this dilemma it seems wise, that such previous measures be in time adopted, as most promise to allay the fury of opposition, to defer amendments till experience has shown defects, and to insure the appointment of able and honest men in the first Congress.

One of the best means to accomplish this seems to me, to bring into the Assembly of Virginia the aid before mentioned. Indeed I know of nothing so effective; for on the conduct of Virginia every thing will depend. Her example will be followed; and, if she supports with promptitude the system recommended by this State, confusion and anarchy may be the substitutes of order and good government.

With much freedom have I disclosed to you, and to you only, my sentiments on the present epoch, as it involves in it yourself. I am persuaded you will attribute my conduct to the motives which gave birth to it, zeal for the public prosperity and solicitude for your fame and happiness. In a few weeks I shall return to Virginia; if by land, I shall pay my respects to you at 
Mount Vernon, when it will be more in my power to explain fully my opinions. I have the honor to be, with unalterable attachment, yours truly,

\section{Henry Lee.}

The following is Washington's answer, which strongly evinces the confidential terms of their friendship, and the respect which Washington entertained for the opinion of Lee.

TO HENRY LEE, IN CONGRESS.

Mount Vernon, 22 September, 1788.

Dear Sir,-Your letter of the 13th instant was of so friendly and confidential a complexion, as to merit my early attention and cordial acknowledgments. I am glad Congress have at last decided upon an ordinance for carrying the new government into execution. In my mind the place for the meeting of the new Congress was not an object of such very important consequence; but I greatly fear, that the question entailed upon that body, respecting their permanent residence, will be pregnant with difficulty and danger. God grant that true patriotism and a spirit of moderation may exclude a narrow locality, and all ideas unfriendly to the Union, from every quarter.

Your observations on the solemnity of the crisis, and its application to myself, bring before me subjects of the most momentous and interesting nature. In our endeavour to establish a new general government, the contest. nationally considered, seems not to have been so much for glory as existence. It was for a long time doubtful 
whether we were to survive as an independent republic, or decline from our federal dignity into insignificant and wretched fragments of an empire. The adoption of the constitution so extensively, and with so liberal an acquiescence on the part of the minorities in general, promised the former; until lately the circular letter of $\mathrm{New}$ York carried, in my apprehension, an unfavorable if not an insidious tendency to a contrary policy. I still hope for the best; but, before you mentioned it, I could not help fearing it would serve as a standard to which the disaffected might resort. It is now evidently the part of all honest men, who are friends to the new constitution, to endeavor to give it a chance to disclose its merits and defects, by carrying it fairly into effect in the first instance. For it is to be apprehended, that, by an attempt to obtain amendments before the experiment has been candidly made, "more is meant than meets the ear," that an intention is concealed to accomplish slily what could not have been done openly, to undo all that has been done.

If the fact so exists, that a kind of combination is forming to stifle the government in embryo, it is a happy circumstance that the design has become suspected. Preparations should be the sure attendant upon forewarning. Probably prudence, wisdom, and patriotism were never more essentially necessary, than at the present moment; and so far as it can be done in an irreproachably direct manner, no effort ought to be left unessayed to procure the election of the best possible characters to the new Congress. On their harmony, deliberation, and decision every thing will depend. I 
heartily wish Mr. Madison was in our Assembly, as I think with you it is of unspeakable importance that Virginia should set out with her federal measures under right auspices.

The principal topic of your letter is to me a point of great delicacy indeed, insomuch that I can scarcely without some impropriety touch upon it. In the first place, the event to which you allude may never happen; among other reasons, because, if the partiality of my fellow citizens conceive it to be a means by which the sinews of the new government are to be strengthened, it will of consequence be obnoxious to those, who are in opposition to it, many of whom unquestionably will be placed among the electors.

This consideration alone would supersede the expediency of announcing any definitive and irrevocable resolution. You are among the small number of those, who know my invincible attachment to domestic life, and that - my sincerest wish is to continue in the enjoyment of it solely until my final hour. But the world would be neither so well instructed, nor so candidly disposed, as to believe me uninfluenced by sinister motives, in case any circumstance should render a deviation from the line of conduct I had prescribed to myself indispensable.

Should the contingency you suggest take place, and (for argument's sake alone let me say it) should my unfeigned reluctance to accept the office be overcome by a deference for the reasons and opinions of my friends, might I not, after the declarations I have made (and Heaven knows they were made in the sincerity of my heart), in the judgment of the impartial world and of 
posterity, be chargeable with levity and inconsistency, if not with rashness and ambition? Nay farther, would there not be some apparent foundation for the two former charges? Now justice to myself and tranquillity of conscience require, that I should act a part, if not above imputation, at least capable of vindication. Nor will you conceive me to be too solicitous for reputation. Though I prize as I ought the good opinion of my fellow citizens, yet, if I know myself, I would not seek or retain popularity at the expense of one social duty or moral virtue.

While doing what my conscience informed me was right, as it respected my God, my country, and myself, I could despise all the party clamor and unjust censure, which might be expected from some, whose personal enmity might be occasioned by their hostility to the government. I am conscious, that I fear alone to give any real occasion for obloquy, and that I do not dread to meet with uumerited reproach. And certain I am whensoever I shall be convinced the good of my country requires my reputation to be put in risk, regard for my own fame will not come in competition with an object of so much magnitude. If I declined the task, it would lie upon quite another principle. Notwithstanding my advanced season of life, my increasing fondness for agricultural amusements, and my growing love of retirement, augment and confirm my decided predilection for the character of a private citizen, yet it would be no one of these motives, nor the hazard to which my former reputation might be exposed, nor the terror of encountering new fatigues and troubles, that would deter me from an ac- 
ceptance; but a belief, that some other person, who had less pretence and less inclination to be excused, could execute all the duties full as satisfactorily as myself. To say more would be indiscreet; as a disclosure of a refusal beforehand might incur the application of the fable in which the fox is represented as undervaluing the grapes he could not reach. You will perceive, my dear sir, by what is here observed, which you will be pleased to consider in the light of a confidential communication, that my inclinations will dispose and decide me to remain as I am, unless a clear and insurmountable conviction should be impressed on my mind, that some very disagreeable consequences must, in all human probability, result from the indulgence of my wishes.

If you return by land, I shall expect without failure the pleasure of your company. I am much indebted to you for your obliging offer of forwarding such articles as I might want from New York, though I shall not have occasion at this moment to avail myself of your goodness. With great regard and esteem, 


\section{CHAPTER XXIII.}

Colonel Lee chosen a member of the Convention of Virginia for ratifying the Constitution of the United States-His earnest support of the Constitution in the Convention-Colonel Lee chosen a member of the House of Delegates of Virginia-Offered a command in the army to act against the Indians-Declines-Chosen governor of Virginia-Proposed as commander of the army against the northwestern Indians-Correspondence with President Washington on this subject.

COLONEL LEE was chosen a member of the Convention of Virginia, which met in June, 1788, for the purpose of considering the propriety of adopting the new Constitution of the United States. He was one of the most strenuous and eloquent supporters of the Constitution, notwithstanding the opposition of some of the most influential men of the State, among whom was Patrick Henry.

None of the patriotic men who supported the Constitution was more gratified than Lee, when after long and earnest debates, the Convention of Virginia finally voted for ratification of the Constitution.

Lee was soon after chosen a member of the House of Delegates in Virginia.

In 1791, Colonel Lee was offered the command of a portion of the army raised by the government of the 
United States to chastise the Indians who were ravaging our northwestern frontier. This office he declined. The troops to act under his command were to consist of three battalions, to be raised in Pennsylvania, Maryland, and Virginia.

In 1792 he retired from his seat in the House of Delegates, on being raised to the high and responsible office of governor of Virginia. He filled the chair of governor for the next three years.

After St. Clair's defeat, Lee was proposed for the chief command of the army to act against the Indians (1792), and in a letter to General Washington he remarks that he might have been appointed. Washington was anxious that he should receive the appointment. Lee appears not to have desired to accept it.

He was not pleased, however, when assured by Colonel Darke that the Secretary of War, General Knox, had opposed the wishes of Washington in this matter.

The following letter from Lee to Washington shows Lee's resentment against Knox; and at the same time evinces an unusual degree of moral courage in Lee. Scarce another man in the country would have dared to address so bold a remonstrance as this to Washington. But Lee was well assured of the good will and candour of his illustrious friend, and knew that his motives would not be misconstrued. The extracts from Lee's letter and from Darke's letter to Lee are as follows: *

From Governor Lee's Letter.- "You cannot have forgotten a declaration, which you made at your own table just before your acceptance of the arduous station you * Sparks' Writings of Washington. 
enjoy, which then sunk deep into my heart, and never can be eradicated, namely, that a frank communication of the truth to you, respecting the public mind, would be ever received as the highest testimony of respect and attachment. Often have I wished to present you with evidences of my affection and devotion in conformity to the above declaration, since your return to public life: but, presuming that you might derive ample information from others, and distrusting my own inquiry and observations, I have heretofore silenced my desire. Nor indeed, for the same reasons, should I now commence the task, did it not appear to me indispensably necessary; for, if the information be accurate, you are deceived and abused by those in whom you place the highest confidence, and consequently your own character, as well as the public interest, may be submitted to derogation and injury. What one minister may have done on one occasion, may extend to all occasions and to all ministers.

"You cannot be a stranger to the extreme disgust, which the late appointment to the command of the army excited among all orders in this State. Whether the same be just or not, is immaterial at present; or whether taking into view all the circumstances of the case a better appointment could have been made, is by no means the object of my inquiry. The event was the subject of general conversation, during which period Colonel Darke visited Richmond, and of course became a party in the opinions and communications given on the occasion. What he said to me was in my judgment necessary to you, and I took the liberty to write to 
Colonel Darke, requesting him to commit to paper the conversation between us the previous day. This he did, and I enclose it for your perusal.

"I thought it proper to send you the original, although the handwriting is rather obscure, lest a copy might in any degree change the meaning of the communication. . If Colonel Darke is right, it follows clearly, that, in a very important matter to yourself and the community, one of your officers exerted himself to increase certain difficulties, which obstructed the execution of your own wishes, instead of endeavoring to remove them; acting in obedience to his own desire, rather than following the decision of his superior. If your ministers dare thus to do, you must be subject to hourly impositions, and the national concerns will be regulated by their and not your judgment. I have not, nor shall I lisp a word of this communication to the gentlemen whom it concerns. For yourself only it is intended. It is not in my power to ascertain whether the same be true or not. You can readily distinguish this fact. ' Colonel Darke is a man of truth and honor, and he speaks positively. You will, I trust, be the event as it may, impute my conduct to the motives which produce it, respect and attachment to yourself. Personally I do not feel on the occasion, only that I cannot dissemble the gratification, which the opinion you were pleased to express of my talents afforded; and indeed I am candid to declare, that I prefer such a testimonial to the office itself, to which I might have been appointed."-Richmond, June 15 th.

From Colonel Darke's Letter to Governor Lee._- In 
answer to your letter, concerning the conversation I had the honor to have with the President, as it was not of a private nature as far as it related to you, I will give as good an account as my memory will allow, as it could not be the President's desire that I should not. He mentioned you as commander-in-chief of the army, spoke much in favor of your abilities in so respectful a manner, that I thought you would certainly have been appointed. He indeed said something of your rank in the late Continental army, and asked me if I would serve, should you be appointed to the chief command; which question I did not answer, though I confess I think I should. But being so distressed in mind, for reasons that I need not mention to you, I did not give his Excellency an answer, but intended to do it before I left town, which I did not. Knowing he was much engaged in business of importance, I was in doubt he would think I intruded; at the same time was determined, if you had been appointed, to have gone with you and given you what little assistance I was capable of, or indeed any other of my acquaintance, that I thought equal to that great and important trust.

"The Secretary of War said something to me concerning my accepting of some appointment. I told him I first wanted to know who would command the army, and said something of you and some others. He let me understand some time after, that he thought I could not serve with you with propriety, honor, or words to that purpose, but that you would not be appointed. This I confess I thought General Knox might be mistaken in, 
as, from what I heard from the President, I had a right to expect you would." - May $12 t h$.

In the following extract from Washington's answer to Lee, it will be observed that he exonerates General Knox, whom he designates by the letters G. K., from having exerted his influence against Lee, and asisigns reasons for his not being appointed which any military man will see are decisive, although they involve no disparagement of Lee's acknowledged courage and ability as a commander. In his answer to Lee, Washington says : *

"I have no hesitation in declaring to you, that the bias of my inclination was strongly in your favor; but that the result of my inquiries, direct and indirect, of military and indeed of other characters, who were well disposed to see you in nomination, was, that, if you were appointed to the command, it would be vain to look for senior officers to act subordinately, or, if they consented, it would be so grudgingly as that more than probably the seeds of sedition would be coeval with the formation of the army, such being the nature of military pride. Admitting this, then, one of two things would inevitably have followed; either an army composed of discontented materials, or of junior characters. The first might be attended with fatal consequences; and as to the other, however excellent the officers might be, if any disaster should befall the army, it would instantly be ascribed to the inexperience of the principal officers in stations to which they had never been accustomed, thereby drawing a weight upon my shoulders too heavy to be borne. This was my own view of the sub-

* Sparks' Writirgs of Washington. Vol. x. p. 247. 
ject, and the principle upon which I acted; not, be assured, because G. K. was of this or of that opinion. The fact, I sincerely believe, is, that he was as much puzzled as I was to fix on the first officer, under the circumstances that existed.

How far the appointment of $G$. W.* is a popular or an unpopular measure, is not for me to decide. It was not the determination of a moment, nor was it the effect of partiality or of influence; for no application (if that in any instance could have warped my judgment) was ever made in his behalf from any one, who could have thrown the weight of a feather into his scale, but because, under a full view of all circumstances, he appeared most eligible. To a person of your observation and intelligence it is unnecessary to remark, that an appointment, which may be unpopular in one place, and with one set of men, may not be so in another place, or with another set of men, and vice vers $\hat{a}$; and that to attempt to please every body is the sure way to please nobody; because the attempt would be as idle, as the exertion would be impracticable. G. W. has many good points as an officer, and it is to be hoped, that time, reflection, good advice, and, above all, a due sense of the importance of the trust, which is committed to him, will correct his foibles, or cast a shade over them. With esteem and regard,

I am, \&c.

* General Wayne, who had been appointed to the command of the western expedition as successor to General St. Clair, who had resigned. 


\section{CHAPTER XXIV.}

Washington's proclamation of neutrality-Lee's opinion on it-His letter to Washington-Death of Mrs. Lee-He wishes to take military service in France-His letter to Washington on the subjectWashington's answer.

No act of Washington's administration has commanded more respect from the reflecting part of his countrymen, than his proclamation of neutrality on the breaking out of the war between England and revolutionary France. It is well understood now, that this act saved the country from endless embarrassments and perils. It is a curious fact, and one which is very decisive of the sound judgment of governor Lee in political affairs, that before receiving this proclamation, he wrote to Washington advising him to issue such a paper. In his letter. he said, "The minds of the people of my acquaintance are much agitated by reports of privateers being fitted out in some of our ports. The considerate part of society hope for peace, which can only be obtained by strict neutrality. Do you not think your proclamation on this subject would be useful? Pardon the suggestion, and regard it only as my opinion; and you know how uninformed I must be on this subject."

General Lee's wife died about this time; and he appears to have suffered the most intense affliction at her 
loss. In his distress he thought of action in the stirring life of the camp, as relief from afflictive thoughts and memories; and as no opportunity of indulging this wish, and returning to his old military pursuits, was presented in his own country, he had serious thoughts of offering his services to the government of France, where he could have received the appointment of Major General.

The following extract from a letter to Washington asking his advice, will fully explain this matter:

"As soon after my hearing of your return to Mount Vernon as I could, I set out on a visit to you, but unfortunately your stay at home was so short, that I could not see you. I had reached Stafford Court-House, when I accidentally learned that you had departed on the previous Sunday; and on knowing this I instantly turned back from whence I came. This disappointment would have always been mortifying to me, as it deprived me of the pleasure of seeing you; but it was uncommonly so then, as I had vast solicitude to obtain your opinion on a subject highly interesting to me personally.

"Bred to arms, I have always since my domestic calamity wished for a return to my profession, as the best resort for my mind in its affliction. Finding the serious turn which the French affairs took last year, I interposed with the Marquis to obtain me a commission in their army, and at the same time made the same application in another way. The Marquis, about the time he got my letter, took the part, which issued so unfortunately to him. From him I had no reply. But from the other source I am informed, that a major-general's commission will be given to me on my appearance in Paris, 18 
and that probably it would be sent to me. I have detailed this to you, merely that your mind might be fully informed, inasmuch as the step I may take will be to me all-important. I am consequently solicitous for the best advice, and this I am persuaded you can give. Should it be improper on your part, much as I want it, I must relinquish the hope. But as your opinion to me will never be known but to myself, and as I ask your counsel in your private character, I feel a presumption in favor of my wishes.

"If fair war on terms of honor, with certainty of sustenance to the troops, and certainty of concert among citizens, will and can be supported by France, I will embark. If the reverse in any part is probable, to go would be the completion of my lot of misery. You see my situation; you have experienced my secrecy in my younger days, and you know the inviolable affection I bear towards you. Apprehend no improper effects of your free opinion to me."-Richmond, April 29th, 1793.

Washington in a letter, dated May 1793, returns the following wise, and friendly answer to Lee's inquiries, which appears to have extinguished Lee's aspirations for distinction in a foreign service. Washington, after touching on other matters, wrote as follows :*

I come now to a more difficult part of your letter. As a public character, I can say nothing on the subject of it. As a private man, I am unwilling to say much. Give advice I shall not. All I can do, then, towards complying with your request is to declare, that, if the case which you have suggested were mine, I should pon-

* Sparks' Writings of Washington. Vol.x. p. 343. 
der well before I resolved; not only for private considerations, but on public grounds. The latter, because, being the first magistrate of a respectable State, much speculation would be excited by such a measure, and the consequences thereof not seen into at the first glance. As it might respect myself only, because it would appear a boundless ocean I was about to embark on, from whence no land is to be seen. In other words, because the affairs of [France] would seem to me to be in the highest paroxysm of disorder; not so much from the pressure of foreign enemies, for in the cause of liberty this ought to be fuel to the fire of a patriot soldier, and to increase his ardor, but because those in whose hands the government is intrusted are ready to tear each other to pieces, and will more than probably prove the worst foes the country has. To all which may be added the probability of the scarcity of bread, from the peculiar circumstances of the contending parties, which, if it should happen, would accelerate a crisis of sad confusion, and possibly of entire change in the political system.

The enclosed came under cover to me by one of the late arrivals. If the date of it is as old as the one to me, which accompanied it, it can contain nothing new. Although no name will appear to this letter, I beg it may be committed to the flames as soon as it is read. I need not add, because you must know it, that I am always yours. 


\section{CHAPTER XXV.}

Lee's opinion on Washington's system of neutrality-Genet's conduct -Correspondence of Washington aud Lee on the subject-Origin of the whiskey insurrection in Pennsylvania-Washington determines to suppress it-Raises an army and gives Lee the command in chief with the rank of Major General-Washington's instructions to Lee-Speedy suppression of the revolt.

WE have already seen that governor Lee was a firm supporter of Washington's system of neutrality towards the belligerent powers of Europe. The following letter to General Washington shows that he continued to follow this course; that he endeavored to prevent the French minister Genet from endeavoring to disturb the state of neutrality, and that he foresaw the pernicious and unprincipled course of conduct which Genet would adoptexciting the citizens of the United States to resist their own government, and endeavoring to involve this country in the war between France and England.

The letter from Lee to Washington, dated Richmond, June 14, 1793, is as follows :

MY DEAR SIR:-Plain and evident as is the wise policy of neutrality on the part of the United States during the present European war, I find that the papers teem with publications reprobating this system.

If $I$ am to judge of the feelings and disposition of the 
people of the United States, from what I believe to be the. temper of Virginia on this question, I cannot doubt, that nine tenths of America applaud the policy adopted, and feel increased gratitude and love for the man, who has declared the same as the rule of conduct for his fellow citizens. There are in all societies, at all times, a set of men anxious for change in the political machine, and fond of confusion. This disposition results in part from love of novelty, from ruined private circumstances, and disappointments in political stations. This class of men receive the aid of the wicked and abandoned of every description, and therefore in free countries are considered more numerous than they really are, because they are noisy, clamorous, and impudent.

But when their weight in society is taken, they will be found as light as straw. So it is here at present. If a stranger were asked his opinion of the wishes of the people of this country with respect to war, he would probably declare the same to be universally favorable; for he would gather his information from the conversations he had heard at taverns, where this order of men abound, gambling and drinking all night, and all day abusing men and measures however respectable, however proper.

I returned yesterday from a visit to our arsenal at the Point of Fork, and took occasion during my journey to talk freely with the planters respecting your proclamation. I found every person regarding it as highly wise, duly timed, and all expressed a confidence in your adhering invariably to its purport.

To my mind these communications were not unex- 
pected, and, yet I professs I derived great satisfaction from them, because, from the clamor issuing out of the towns and promulgated in the papers, I began to fear that the golden prospects of felicity before us would be lost by our country, in spite of the wisdom and firmness of our government; and I have been induced to give to you my observations thereon, as in your situation at this crisis the happiness of the people requires you should be well acquainted with their opinions.

When M. Genet was here, we conversed very freely with respect to the neutrality of the United States. I attempted to convince him, and I thought with some effect, that, from the superiority of the enemy's fleet, it was the only way we could take, which promised to France those provisions which we had, and which she might want; and concluded the argument $I$ held on this subject by asserting, that, had you determined to prefer the interests of France to every other consideration, you could not have acted more effectually than you did, when you issued your proclamation, and that happily on this occasion, while you did the greatest good to the United States, you did all the good possible to their ally; that we had no fleet, no army, no money to authorize us to take a part in the war with effect, and to do it pitifully was to risk our own destruction, without the consolation of affording material aid to our friends.

He seemed to acquiesce in my reasoning, but insinuated, that, in case the royal government was reëstab lished in France, the kings of Europe would combine to destroy liberty here, and that our existence as a nation depended upon the success of the republican system, 
and that we might conveniently make important diversions in her favor on our southern and northern neighbors.

To this I opposed our infant situation as a people, our love of peace, the heavy debt which oppresses us in consequence of the last war, the probable futility of such vast enterprises, and the certainty that France would derive more benefit from holding within her own bosom all her means of men and money, than she possibly could by such Quixotic adventures. I augured ill of their late efforts against Belgium, (which have turned out since as I presumed,) and contended that the sure way to effect their object was to be content with defending their own country.

The impressions, which he seemed to entertain when we parted, induced me to hope that he would never attempt to disturb the system of neutrality adopted.

But opinions of moderation and wisdom can scarcely be held long by any man in his situation, when our citizens seem to take an active part in commending very opposite conduct. I judge by what I read in the Philadelphia papers, then, that his mind will be soon turned from those proper sentiments, which he possessed when here, and that our only route to national prosperity may experience new obstructions.

But, Sir, let whatever may happen or be effected, in your firmness we all rest thoroughly convinced, that you can never be brought to depart from that line of conduct, which in your judgment best promotes the public good. 
With best wishes for your health and happiness, I am ever your most affectionate friend and humble servant.

\section{Henry Lee.}

\section{Washington's answer was as follows:}

"The communications in your letter were pleasing and grateful; for, although I have done no public act with which my mind upbraids me, yet it is highly satisfactory to learn, that the things which I do, of an interesting tendency to the peace and happiness of this country, are generally approved by my fellow citizens. But, were the case otherwise, I should not be less inclined to know the sense of the people upon every matter of great public concern; for, as I have no wish superior to that of promoting the happiness and welfare of this country, so, consequently, it is only for me to know the means to accomplish the end, if it be within the compass of my powers.

"That there are in this, as well as in all other coun. tries, discontented characters, I well know; as also that these characters are actuated by very different views; some good, from an opinion that the measures of the general government are impure; some bad, and, if I might be allowed to use so harsh an expression, diabolical, inasmuch as they are not only meant to impede the measures of that government generally; but more especially, as a great means towards the accomplishment of it, to destroy the confidence, which it is necessary for the people to place, until they have unequivocal proof of demerit, in their public servants. In this light I consider myself, whilst I am an occupant of office; and, if 
they were to go further and call me their slave, during this period I would not dispute the point.

"But in what will this abuse terminate? For the result, as it respects myself, I care not; for I have a consolation within, that no earthly efforts can deprive me of, and that is, that neither ambitious nor interested motives have influenced my conduct. The arrows of malevolence, therefore, however barbed and well pointed, never can reach the most vulnerable part of me; though, whilst I am up as a mark, they will be continually aimed. The publications in Freneau's and Bache's papers are outrages on common decency; and they progress in that style, in proportion as their pieces are treated with contempt, and are passed by in silence, by those at whom they are aimed. The tendency of them, however, is too obvious to be mistaken by men of cool and dispassionate minds, and, in my opinion, ought to alarm them; because it is difficult to prescribe bounds to the effect.

"The light in which you endeavored to place the views and conduct of this country to M. Genet, and the sound policy thereof, as it respected his own, was unquestionably the true one, and such as a man of penetration, left to himself, would most certainly have viewed them in; but mum on this head. Time may unfold more than prudence ought to disclose at present."

Some further correspondence took place between Washington and Lee, respecting the proceedings of Genet, and the fashion of Jacobin Clubs which he introduced into this country, for the purpose of involving it in such scenes of bloody anarchy as had been enacted in 
France under the auspices of the original Jacobin Club of Paris. It appears by the correspondence of Washington and Lee, and indeed it is a well known fact of history, that the Democratic Societies, as these clubs were called, supported the opposers of government in the famous Whiskey Insurrection in Pennsylvania.

One of the measures of Washington's administration for raising revenue for the support of the government, and paying the interest on the national debt, was an excise duty on whiskey of domestic manufacture. This was openly resisted by the people of the western counties of Pennsylvania, and the officers of government were prevented from performing their duty by force of arms. Conciliatory measures, far from terminating, only increased the evil. The insurgents, misled by the Democratic Societies and other opponents of the government, gathered strength from the supposed weakness of a government which tried conciliation with them, and the insurrection assumed a very formidable aspect.

It was impossible for Washington to tolerate such a state of things as this, and he determined to put down the insurrection by military force.

An army of fifteen thousand men was speedily raised, consisting of militia from the States of Pennsylvania, New Jersey, Maryland, and Virginia, and a large number of volunteers from these states. So determined were the people to sustain the laws that men of the highest standing and influence in the community, shouldered their muskets, and took their places in the ranks as private soldiers.

Washington appointed Governor Lee commander-in- 



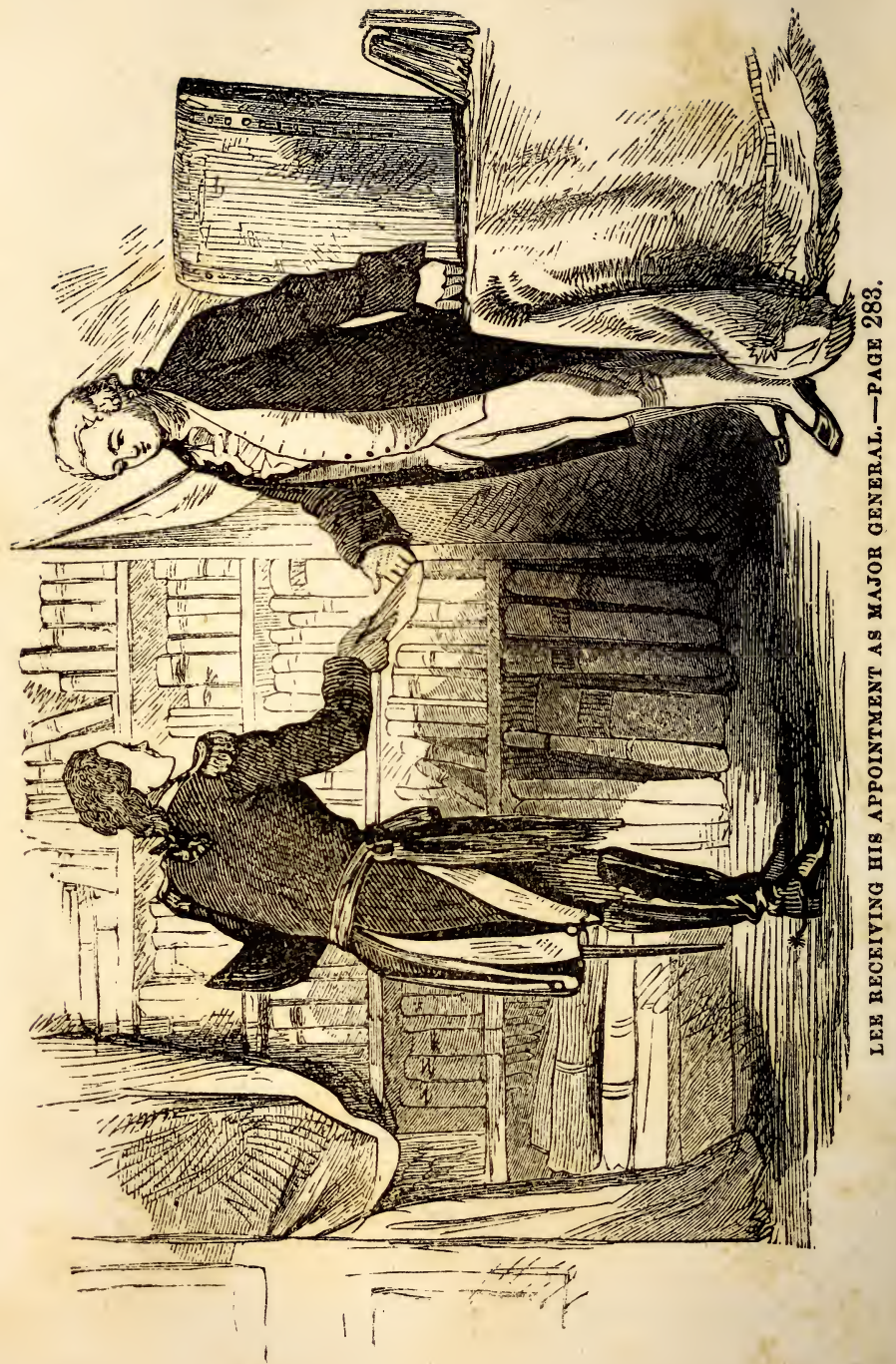


chief of this force, with the rank of Major General ; and when a portion of the army was assembled at Bedford, he went to that place in person to superintend the arrangements for their march to the revolted counties. The following is his letter of instructions to General Lee before returning to Philadelphia, where his presence was required in consequence of the approaching session of Congress.

TO HENRY LEE, COMMANDER-IN-CHIEF OF THE MILITIA ARMY.

BeDFord, 20th October, 1794.

Sir:-Being about to return to the seat of government, I cannot take my departure, without conveying through you to the army under your command, the very high sense $I$ entertain of the enlightened and patriotic zeal for the constitution and the laws, which has led them cheerfully to quit their families, homes, and the comforts of private life, to undertake and thus far to perform a long and fatiguing march, and to encounter and endure the hardships and privations of a military life. Their conduct hitherto affords a full assurance, that their perseverance will be equal to their zeal, and that they will continue to perform with alacrity whatever the full accomplishment of the object of their march shall render necessary :

No citizens of the United States can ever be engaged in a service more important to their country. It is nothing less than to consolidate and to preserve the blessings of that revolution, which, at much expense of blood and treasure, constituted us a free and independent 
nation. It is to give the world an illustrious example, of the utmost consequence to the cause of mankind. I experience a heart-felt satisfaction in the conviction, that the conduct of the troops throughout will be in every respect answerable to the goodness of the cause and the magnitude of the stake.

There is but one other point on which I think it proper to add a special recommendation; it is, that every officer and soldier will constantly bear in mind, that he comes to support the laws, and that it would be peculiarly unbecoming in him to be in any way the infractor of them; that the essential principles of a free government confine the province of the military, when called forth on such occasions, to these two objects, first, to combat and subdue all who may be found in arms in opposition to the national will and authority, secondly, to aid and support the civil magistrates in bringing offenders to justice. The dispensation of this justice belongs to the civil magistrate; and let it ever be our pride and our glory to leave the sacred deposit there inviolate. Convey to my fellow-citizens in arms my warm acknowledgments for the readiness, with which they have hitherto seconded me in the most delicate and momentous duty the chief magistrate of a free people can have to perform, and add my affectionate wishes for their health, comfort, and success. Could my further presence with them have been necessary, or compatible with my civil duties at a period when the approaching commencement of a session of Congress particularly calls me to return to the seat of government, it would not have been withheld. In leaving them I have the less 
regret, as I know I commit them to an able and faithful direction, and that this direction will be ably and faithfully seconded by all. I am, \&c.

Bedford was the rendezvous of the troops from New Jersey and Pennsylvania, and Cumberland on the Potomac for those of Maryland and Virginia. The governors of New Jersey and Pennsylvania commanded the militia of their respective states and acted under the orders of Lee.

From Cumberland and Bedford, the army marched in two divisions into the country of the insurgents. The greatness of the force prevented the effusion of blood. The disaffected did not venture to assemble in arms. Several of the leaders, who had refused to give assurances of future submission to the laws, were seized, and some of them detained for legal prosecution.

But although no direct and open opposition was made, the spirit of insurrection was not subdued. A sour and malignant temper displayed itself, which indicated, but too plainly, that the disposition to resist had only sunk under the pressure of the great military force brought into the country, but would rise again should that force be withdrawn. It was, therefore, thought advisable to station for the winter, a detachment to be commanded by Major General Morgan, in the centre of the disaffected country.

Thus, without shedding a drop of blood, did the prudent vigor of the executive terminate an insurrection, which, at one time, threatened to shake the government of the United States to its foundation.*

$$
\text { *.Marshall. }
$$




\section{CHAPTER XXVI.}

War with France-Army to be raised provisionally-Washington names Lee as one of the Major Generals-Lee elected to Congress -Death of Washington announced-Lee writes the resolutions moved in Congress by General Marshall-Appointed by Congress to deliver the Funeral Eulogy on Washington-Serves in Congress during Adams's administration-Retires to private life.

General Lee continued to serve as governor of Virginia for three years. It was during the last of these years, 1795 , that he led the army against the insurgents of Pennsylvania. He now retired to private life.

In 1798, the insults of the revolutionary government of France, and the depredations of French cruisers on the commerce of the United States, roused the whole country to indignation. The attempt of Talleyrand to obtain money from our ambassadors as the price of peace, received the reply of one of their number, General Pinckney, which has since become so celebrated: "Millions for defence, but not a cent for tribute." These words became the war cry of the nation; and preparations for hostilities were entered upon with lively zeal.

An army was ordered to be raised provisionally for the emergency which was supposed to be approaching, and the President, John Adams, appointed General 
Washington Lieutenant General and Commander-in-chief. In selecting the other officers, the name of General Lee was placed on the list as one of the Major Generals by Washington. The arrangements with regard to the organization of the Provisional Army occupied the attention of Washington during the remainder of his life; and we learn from his correspondence that he had recourse to the advice of General Lee with respect to the appointment of officers for the different corps of the army.

These preparations, doubtless, had their influence in convincing the French government that the government of the United States was not to be trifled with, and the terms of peace being arranged, the Provisional Army was never called into active service. But peace was not restored till after the decease of General Washington.

In 1799, General Lee was elected a member of Congress, from Virginia. On the second of December the session of Congress commenced. On the eighteenth of the same month, General John Marshall, the future biographer of Washington, and then a member of the House of Representatives, with much emotion, "in a voice," says the record, "that bespoke the anguish of his mind, and a countenance expressive of the deepest regret," rose, and delivered himself as follows:

Mr. Speaker: Information has just been received, that our illustrious fellow-citizen, the Commander-inChief of the American Army, and the late President of the United States, is no more!

Though this distressing intelligence is not certain, there is too much reason to believe its truth. After receiving information of this national calamity, so heavy 
and so afflicting, the House of Representatives can be but ill fitted for public business. I move you, therefore, they adjourn.

The motion was unanimously agreed to; and then the House adjourned till to-morrow morning, 11 o'clock.

On the next day, (December 19th,) Mr. Marshall addressed the Chair as follows:

Mr. Speaker: The melancholy event which was yesterday announced with doubt, has been rendered but too certain. Our Washington is no more! The Hero, the Sage, the Patriot of America-the man on whom in times of danger every eye was turned and all hopes were placed-lives now only in his own great actions, and in the hearts of an affectionate and afflicted people.

If, sir, it had even not been usual openly to testify respect for the memory of those whom Heaven had selected as its instruments for dispensing good to men, yet such has been the uncommon worth, and such the extraordinary incidents which have marked the life of him whose loss we all deplore, that the whole American nation, impelled by the same feelings, would call with one voice for a public manifestation of that sorrow which is so deep and so universal.

More than any other individual, and as much as to any one individual was possible, has he contributed to found this our wide-spreading empire, and to give to the Western world its independence and its freedom.

Having effected the great object for which he was placed at the head of our armies, we have seen him converting the sword into the ploughshare, and voluntarily sinking the soldier in the citizen. 
When the debility of our federal system had become manifest, and the bonds which connected the parts of this vast continent were dissolving, we have seen him the Chief of those patriots who formed for us a constitution, which, by preserving the Union, will, I trust, substantiate and perpetuate those blessings our Revolution had promised to bestow.

In obedience to the general voice of his country, calling on him to preside over a great people, we have seen him once more quit the retirement he loved, and in $\approx$ season more stormy and tempestuous than war itself, with calm and wise determination, pursue the true interests of the nation, and contribute, more than any other could contribute, to the establishment of that system of policy which will, I trust, yet preserve our peace, our honor, and our independence.

Having been twice unanimously chosen the Chief Magistrate of a free people, we see him at a time when his re-election, with the universal suffrage, could not have been doubted, affording to the world a rare instance of moderation, by withdrawing from his high station to the peaceful walks of private life.

However the public confidence may change, and the public affections fluctuate with respect to others, yet with respect to him they have, in war and in peace, in public and in private life, been as steady as his own firm mind, and as constant as his own exalted virtues.

Let us then, Mr. Speaker, pay the last tribute of respect and affection to our departed friend-let the Grand Council of the nation display those sentiments which the nation feels. 
For this purpose I hold in my hand some resolutions, which I will take the liberty to offer to the House.

Mr. Marshall having handed them in at the table, they were read, and unanimously agreed to by the House, in the words following, to wit:

The House of Representatives of the United States, having received intelligence of the death of their highly valued fellow-citizen George Washington, General of the Armies of the United States, and sharing the universal grief this distressing event must produce, unanimously resolve :

1. That this House will wait on the President of the United States, in condolence of this national calamity.

2. That the Speaker's chair be shrouded with black, and that the members and officers of the House wear mourning, during the session.

3. That a joint committee of both Houses be appointed to report measures suitable to the occasion, and expressive of the profound sorrow with which Congress is penetrated, on the loss of a citizen, first in war, first in peace, and first in the hearts of his countrymen.

4. That when this House adjourn, it will adjourn until Monday next.

Ordered, That Mr. Marshall and Mr. Smith be appointed a commmittee to wait on the President of the United States, to know when and where he will receive this House for the purpose expressed in the first resolution.

Ordered, That Mr. Marshall, Mr. Craik, Mr. Henry Lee, Mr. Eggleston, Mr. Smith, Mr. Stone, Mr. Rutledge, Mr. Abiel Foster, Mr. Muhlenburg, Mr. Van 
Cortlandt, Mr. Dwight Foster, Mr. Franklin Davenport, Mr. Claiborne, Mr. Morris, Mr John Brown, and Mr. Taliaferro, be a committee, jointly with such committee as may be appointed on the part of the Senate, for the purpose expressed in the third resolution.

The reader will observe that the expression, since so often quoted, "First in war, first in peace, and first in the hearts of his countrymen," occurs in the resolutions proposed by General Marshall on this mournful occasion; but General Marshall, in his life of Washington, is careful to inform his readers that the resolutions were prepared by General Lee, who, happening not to be in his place when the melancholy intelligence was received and first mentioned in the House, placed them in the hands of General Marshall who proposed them for adoption the next day.

General Lee was appointed to deliver Washington's Eulogy at the public Funeral. The proceedings are thus noted on the record:

\section{Thursday, December 26.}

This being the day appointed by the resolution of Congress for the funeral procession in honor of the memory of George Washington, late General of the Armies of the United States, the House proceeded to the German Lutheran Church, where they attended the funeral oration, prepared and delivered on the occasion by Major General Lee, one of the members of this House for the State of Virginia.

The House, having returned, adjourned until to-morrow morning. 
A part of the record of proceedings on the 30 th of December, is as follows :

The Speaker informed the House that, in pursuance of the resolution of Friday last, he had addressed to $\mathrm{Ma}$ jor General Henry Lee, one of the members for the State of Virginia, the following letter :

\section{"Philadelphia, Dec. 27, 1799.}

"Dear Sir:-The enclosed resolutions, which unanimously passed the House of Representatives this day, will make known to you how highly they have been gratified with the manner in which you have performed the service assigned to you, in preparing and delivering a funeral oration on the death of General Washington. That our constituents may participate in the gratification we have received; from your having so well expressed those sentiments of respect for the character, of gratitude for the services, and of grief for the death of that illustritrious personage, I flatter myself you will not hesitate to comply with the request of the House, by furnishing a copy of your oration, to be taken for publication.

"Allow me, while performing this pleasing task of official duty in communicating an act of the Representatives of the people, so just to you and so honorable to themselves, to embrace the opportunity to declare that I am, personally, with great esteem and sincere regard, dear sir, your friend and obedient servant,

"The Hon. Maj. Gen. LeE."

\section{"THEOdORE SEDGWICK.}

To which Mr. Lee had replied as follows: 


\section{"Franklin Court, Dec. 28, 1799.}

"Dear Sir:-I owe to the goodness of the House of Representatives the honor which their resolutions confer on my humble efforts to execute their wish.

"I can never disobey their will, and therefore will furnish a copy of the oration delivered on the late afflicting occasion, much as I had flattered myself with a different disposition of it.

"Sincerely reciprocating the personal considerations with which you honor me, I am, very respectfully, sir, your friend and obedient servant,

\section{"Henry Lee.}

"The Speaker of the House of Rep's."

General Lee, thus prominently brought forward on his first appearance in Congress under the new Constitution, subsequently took an active part in the debates, and continued to serve until the close of Mr. Adams's administration, when he retired to private life. After this period he never held any conspicuous public office. 


\section{CHAPTER XXVII.}

Private life-Pecuniary embarrassments-Literary pursuits-Memoirs-The Baltimore mob-General Lee wounded and General Lingan killed in defending the liberty of the press-General Lee's health ruined-He goes to the West Indies-Returns--Visits Mrs. Shaw in Georgia-Dies on her plantation-Character of General Lee.

ON his retirement to private life, General Lee found himself seriously embarrassed in his pecuniary affairs. His military services had obtained for him more honor than profit. His subsequent appointment to high civil offices had been by no means lucrative; but had imposed upon him the necessity of entertaining a great deal of company; and his disposition being genial and hospitable, he had spent more money in exercising the rites of hospitality than he could well afford.

This led to the gradual accumulation of debt upon debt, and in 1809, we find him confined within the bounds of Spotsylvania county, on account of pecuniary obligations. It is fortunate for the literature of our country that this was the case; for, in the succeeding three years, he produced the work on which his literary reputation will hereafter rest, the "Memoirs of the War in the Southern Department of the United States." This is one of the best works which has ever been writ. 
ten on the Revolutionary War. As we have copicusly quoted from it, in the present work, it is superfluous for us to make any remarks on its style; but we may be permitted to observe that so far as regards the war in the Southern States, it is complete, clear, circumstantial, and satisfactory. In all matters in which the writer himself was concerned, it has all the vividness and graphic force which might be expected from an intelligent eye-witness; and in those actions where he was not personally present, he has had recourse to the best written authorities, and to the testimony of other officers who were his personal acquaintance. All subsequent writers on the Revolution have had recourse to this work, and have regarded it as reliable authority. It was published in Philadelphia in 1812.

General Lee's brilliant career as a military commander, and as a statesman, would naturally lead the reader to anticipate a peaceful and glorious termination to his eventful life. But unfortunately this was not his destiny. When war was declared by the United States against Great Britain, (June 18th, 1812), General Lee was in Baltimore. He was the personal friend of $\mathrm{Mr}$. Hanson, the Editor of the Baltimore Federal Republican which was published in that city. Two days after the declaration of war, June 20th, an article appeared in this paper announcing a determined opposition to the war and its supporters. Two days after this publication a mob pulled down the printing office, occupied by the editors of the paper, and destroyed their printing press.

While the rioters were being prosecuted for this breach of the peace, Mr. Hanson and his friends took 
possession of a building in Charles Street, renewed the paper, and armed for the defence of the office. It was soon attacked by the mob, and defended by Hanson and his friends, and several of the assailants were killed and others wounded by fire arms. A field piece was brought to bear upon the building, when the civil authorities interfered. What followed we copy from the report of a committee of the city councils made to the Mayor of Baltimore :

"The assailants with their field piece by the interposition of several citizens were restrained from firing upon the house, under an assurance that the persons in it would surrender themselves to the civil authority; the military soon after appeared and placing themselves in front of the house no further injury occurred, a negotiation took place with those within the house, and upon being assured that a military guard would be furnished, and every effort used by the mayor and the general to ensure their safety from violence, they surrendered themselves to the civil authority about seven o'clock on the morning of Tuesday, and were conducted to jail and committed for further examination; they were Alexander C. Hanson, General Henry Lee, General James M. Lingan, William Schroder, John Thompson, William B. Bend, Otho Sprigg, Henry Kennedy, Robert Kilgour, Henry Nelson, John E. Hall, George Winchester, Peregrine Warfield, George Richards, Edward Gwinn, David Hoffman, Horatio Bigelow, Ephraim Gaither, William Gaither, Jacob Schley, Mark U. Pringle, Daniel Murray, and Richard S. Crabb. After the removal of the persons, the interior of the house was great- 
ly injured, and the furniture in it destroyed and dispersed.

"The committee further report, that during the course of the day the mayor applied to the sheriff to use part1cular precaution in securing the doors of the jail, which he promised to do, and about one o'clock application was made by the mayor and other justices, to the brigadier general to call out the military to preserve the peace and quiet of the state. Orders were issued calling out a regiment of infantry, two troops of cavalry, and two companies of artillery, to parade at an appointed time and place. The mayor, the general, and many citizens repaired to the jail early in the afternoon, at which a number of persons had assembled, the much greater part of whom were peaceable and orderly citizens; those of a different temper of mind upon being remonstrated with, appeared to yield to the admonitions of others, and to be appeased with the assurances given that the party in gaol should not be bailed or suffered to escape during the night, it became the prevailing opinion about the prison that no mischief would be attempted that night; in consequence of which, and of the insufficiency of the force assembled, the military, by the order of the general, with the approbation of the mayor, were dismissed; and many persons left the prison and went to their homes. Shortly after dark, the number of the disorderly increased, and an intention was manifested of breaking into the jail; the mayor, with the aid of a few persons, succeeded for some time in preventing the prison door from been forced open; they being overpowered by the increased numbers and violence of the 
assailants, the mayor was forced away; and the door having been previously battered, and again threatened, was opened by the turnkey.* Upon the entry of the assailants, they forced the inner doors and pressed into the room in which the persons above-mentioned were confined. Here a scene of horror ensued which the committee cannot well describe. The result was, that one of the persons (General Lingan) was killed, eleven others dreadfully beaten, eight of whom were thrown together in front of the jail, supposed to be dead."

Thus far the report of a committee who themselves at the time the report was made, were no doubt in terror of another Baltimore mob, and glossed over the affair as well as they could. Its horror and atrocity has never, we believe, been surpassed in the history of mobs.

General Lee was among those who were severely wounded; and the injuries which he received then and there, so effectually broke down his naturally firm and strong physique, that he never knew a moment of respite from disease and suffering for the remainder of his life; though he lived near six years after this brutal attack on his person.

In the hope of some benefit from change of air, he repaired to the West Indies. But this was of no avail.

Returning from the West Indies in 1818, he paid a visit to Mrs. Shaw, the daughter of his old commander General Greene, who was then residing on Cumberland * Not Mr. Greene, the regular turnkey. 
Island, near St. Mary's, Georgia; and at this place on the 25th March, 1818, General Lee breathed his last.

From a member of the family we learn that General Lee was married a second time, and that one of the sons by this marriage is an officer in the Navy of the United States. Other details of his family connections we have not been able to obtain.

After the account which we have given of General Lee's life and actions in the foregoing pages, it seems almost superfluous to attempt a portrait of his character. We have seen the purity of his patriotism, his undaunted courage, his high sense of the claims of honor and humanity, his ability as a military commander, his unceasing care of the welfare of his men, his constant vigilance as a disciplinarian, and his brilliant success in military undertakings which had baffled the efforts of officers older and supposed to be abler than himself. We have witnessed his patriotism and ability as a statesman and politician; and we have had frequent occasion to observe that the illustrious Washington, one of the keenest detectors of the real traits of human character that ever lived, and who never tolerated the slightest dereliction from truth and honor, distinguished Lee by the warmest friendship, from the moment when he mustered his troop at Morristown in 1777, till the Father of his country breathed his last at Mount Vernon. Washington advocated Lee's claims for promotion with Congress; and distinguished him by placing him always in the noblest theatre for active military service; and when Lee was placed in the legislative councils of the nation, and Washington in the supreme executive chair, the latter 
often consulted the former in relation to important public measures.

In private the friendship of these illustrious men was still more remarkable. Lee seems to have been almost the only man living who could take a personal liberty with Washington, without instant and stern rebuke. The following anecdote which we transcribe from Irving's Life of Washington will illustrate this point:

Colonel Henry Lee, too, who used to be a favored guest at Mount Vernon, does not seem to have been much under the influence of that "reverential awe" which Washington is said to have inspired; if we may judge from the following anecdote. Washington one day at table mentioned his being in want of carriage horses, and asked Lee if he knew where he could get a pair.

"I have a fine pair, general," replied Lee, "but you cannot get them."

"Why not?"

"Because you will never pay more than half price for any thing; and I must have full price for my horses."

The bantering reply set Mrs. Washington laughing, and her parrot perched beside her, joined in the laugh. The general took this familiar assault upon his dignity in great good part. "Ah, Lee, you are a funny fellow," said he,-_"see, that bird is laughing at you." *

To have been on such terms of intimacy at Mount Vernon, implies a very amiable and estimable character; and convinces us that with the high qualities of a great

* Communicated to us in a letter from a son of Colonel Lee. 
commander and sound statesman, Lee united the gentle amenities of private life.

Among the brave and able men whose military services gave liberty and independence to the United States, General Lee will always be placed in the highest rank. On this point there can be no debate. History bears testimony to his invaluable services; and posterity will not fail to recognize his claims to immortal honor. 

MAJOR GENERAL THOMAS SUMTER.

(303) 

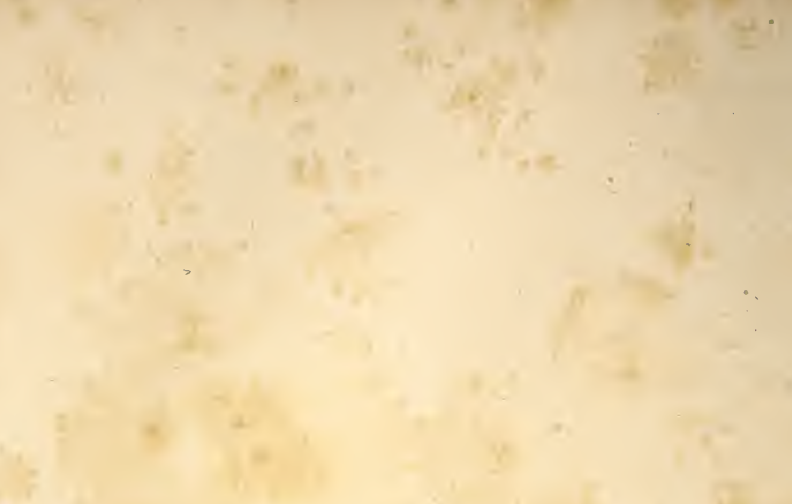

$+2$

4
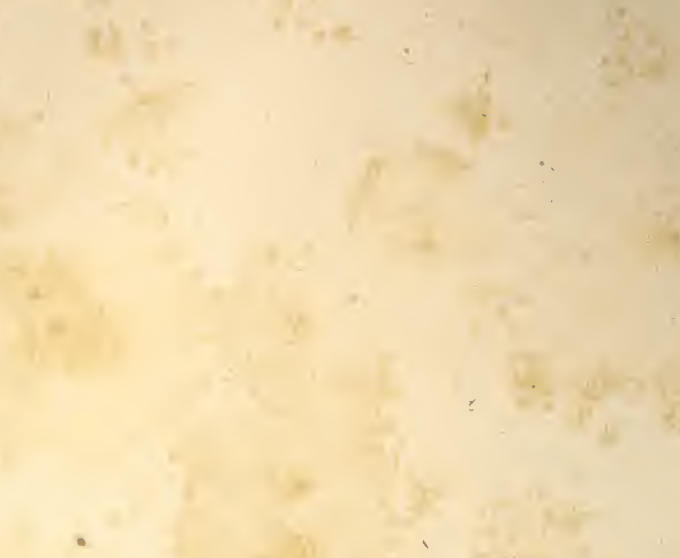

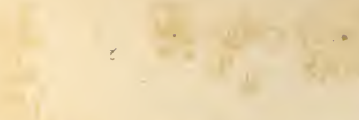

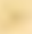

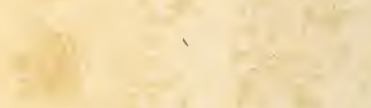

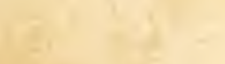

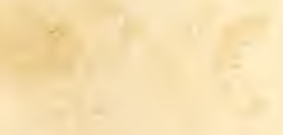

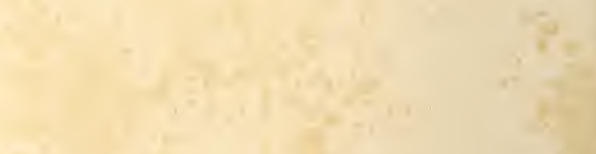

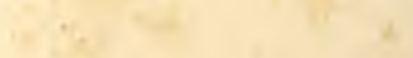
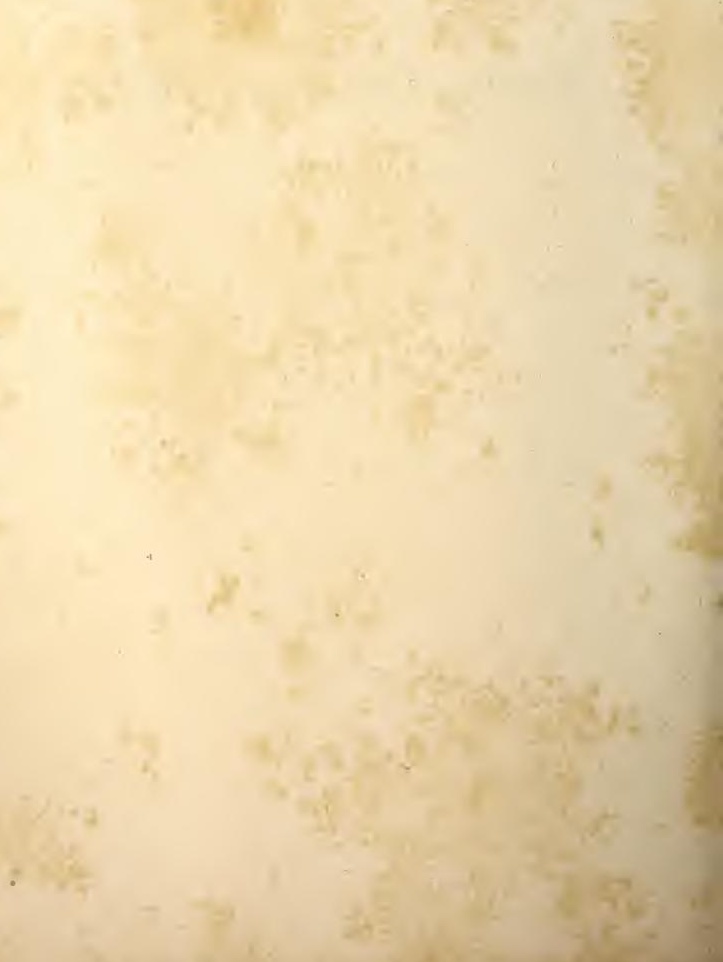

4 


\section{I F E O F}

\section{MAJOR GENERAL THOMAS SUMTER.}

\section{CHAPTER I.}

Birth of General Sumter-Services in the old French War-Distinguished by Lord Dunmore-At the defeat of General BraddockServices in the Cherokee war-Goes to England with Occonostotah -Returns to the Indian country-Arrests a French EmissaryTakes an active part in opposing the oppression of Great Britain -Appointed Lieutenant Colonel-Stationed in the interior-Battle of Fort Moultrie-Second Cherokee War-Fall of CharlestonFlight of patriots-Burning of Sumter's house-Sumter raises recruits-Origin of his soubriquet of the "Game Cock"-Recruits -Arms.

General Sumter was born in Virginia in 1734. Of his education and early life we have no record. It is known, however, that he served as a volunteer against the French and Indians in the Seven Years' War, commonly called by the soldiers, the Old French War, to distinguish it from the war of the Revolution. In this war his courage, activity, and intelligence, attracted the notice of Lord Dunmore, the last royal governor of the 
colony of Virginia. In consequence of this, he was employed in important and hazardous enterprises by the governor.

In the famous expedition of Braddock, Sumter served as one of the Virginia Rangers, who were instrumental, under the guidance of Washington, in saving the remnant of Braddock's army at the disastrous battle of the Monongahela.

After the fall of Fort Duquesne, the Cherokees became, by French influence, involved in a war with the Carolinians, and in 1760, and 1761, several expeditions were sent into the country of that tribe under the British officers Grant, Middleton, and Montgomery.

In this service he rose by promotion in military rank; and when peace was concluded he was appointed to accompany the Indian Chief Occonostotah, or the "Emperor," to England; it being common at that time to induce Indian Chiefs to visit the mother country for the purpose of confirming their friendship to the colonists.

On returning with Occonostotah to his home, in 1763, Sumter found among the Indians, one Baron des Johnes, a French Canadian, who spoke seven of the Indian languages. This man he suspected on very sufficient grounds to be a French emissary, whose business among the Indians was to stir them up to renewed hostilities against the people of South Carolina. Being well satisfied on this point, he determined to take the responsibility of arresting him, and carrying him off a prisoner. It was an enterprise of no small hazard and personal risk; but Sumter was a man of the most daring courage and determination; and in spite of the opposition of the Indians, he 
accomplished his purpose. His noble presence and air of command, as well as his high reputation as a military commander, no doubt, stood him in good stead on this occasion. He safely conducted his prisoner to Fort George on the Kehowee. Des Johnes was afterwards sent to Charleston where he was examined, and though his guilt was not positively proved, it was deemed expedient to send him to England.

During the excitement which preceded the outbreak of the Revolution, Sumter was in Charleston, and in 1774 , and 1775 , he took an active part among the opposers of the British government in their assumption of arbitrary power. The provisional congress of South Carolina, when organizing an army, did not lose sight of this patriotic soldier, and in March 1776, they appointed him lieutenant colonel of the second regiment of riflemen.

This regiment was stationed in the interior, where it served to keep in awe the tories and Indians, who were ever ready to commence hostilities against the patriots. Sumter, consequently, was not present at the battle of Fort Moultrie, (June 1776).

Two days after this battle a new Cherokee war broke out, and was terminated by destroying the Indian towns as in the previous war of $1760-61$. Sumter's regiment was probably engaged in this war, but we find no record of the fact.

In May 1780, Charleston was taken by the British army under the Commander-in-chief Sir Henry Clinton; and as nearly the whole disposable force of the colony had been engaged in its defence, they hecame prisoners 
of war. The whole state was treated as a conquered country, and all who would not submit to British authority were compelled to seek safety in concealment or flight.

Sumter was one of the fugitives.* He retired to the swamps of the Santee, from the shelter of which he beheld his wife driven from her dwelling, as the wife of an outlawed rebel, and the torch of the incendiary applied to his habitation. The sense of personal wrong added fuel to the flames of patriotism. He emerged from his hiding-place, and gathered his friends about him. Too few for such enterprises as his eager courage demanded, he made his way into North Carolina seeking recruits. One of the traditions by which his course along the frontiers of this state was marked, is here in place, as equally illustrative of his progress and his character. He found himself one day at a place known as the "Gillespie settlement." Of the Gillespie family there were numerous brothers, who were all famous cock-fighters. They were content with the conflicts of the barn-yard, having in their possession, among other famous fightingbirds, a blue hen of the game species, whose progeny were particularly distinguished for their martial qualities. Of one of these chickens, called Tuck, there is quite a biography. His reputation was extended far and wide, from mountain to mountain. He was never known to refuse a fight, or to lose a battle. Sumter suddenly appeared at the cockpit, and surprised the Gillespies at their usual occupation. They looked up, and were struck with the bold and military aspect of the stran* Washington and the Gencrals of the American Revolution 
ger. His well-made person, muscular without bulk, impressed them with respect. His eye had in it that fiery courage which they were accustomed to admire; and they were not offended, when, with something contemptuous in his voice and manner, as he referred to their amusement, which was at once child-like and cruel, he called upon them, in abrupt and energetic language, to leave the cockpit, and "go with him where he should teach them how to fight with men!" They took him at his word. "Tuck, for ever!" was the cry of the Gillespies; "he is one of the Blue Hen's chickens!" The sobriquet stuck to him always after; and the eagerness with which he sought his enemy on all occasions, and frequently without duly measuring the inequalities of the parties, amply justified, in the opinion of his followers, the nom de guerre of the "Game Cock," which they always coupled with his name.*

Sumter was comparatively successful in procuring recruits. He obtained a greater number than he could arm. He was reduced to great straits for weapons. old millsaws were converted by rude blacksmiths into broad swords. Knives, fastened to the ends of poles, made tolerable lances. The pewter of ancient housekeepers was run into bullets, and supplied the few fowling-pieces which he could procure with a few rounds of missileș; but, with all these rude helps and appliances,

* The propriety of the epithet was very soon acknowledged by the enemy. Tarleton, on one occasion, having hunted for Marion in vain, is reported to have said to his officers, "Come, let us leave hunting this $d-d$ 'Swamp Fox,' and see if we cannot find the 'Game Cock.'" 
it was still the case that a portion of his men had to keep aloof in the action, waiting till the fall of the enemy, or of their comrades, should yield them an opportunity of obtaining weapons. But these deficiencies offered no discouragement to Sumter. He very quickly proceeded to give the Gillespies the amusements which he had promised them. The British and their tory allies soon offered him a proper opportunity. 


\section{CHAPTER II.}

Condition of the Carolinas-Cornwallis and Rawdon's position-Gates advancing-Marion, Sumter, Pickens-Movements of Rawdon Sumter assaults the British fort at Rocky Mount-Davie's success at Hanging Rock-Sumter's attempt on Rocky Mount foiled by the misconduct of his men-He retreats to his asylum.

A $\mathrm{T}$ the time of Sumter's appearance apon the grand theatre of the Southern War, Sir Henry Clinton had left Lord Cornwallis in command of the British army in the Southern States, with Lord Rawdon as the second in command. A proclamation had been issued calling upon the prisoners of war taken at Charleston, and paroled, to take up arms in the royal cause, and great numbers, disgusted by this bad faith of the British commanders, were ready to join the army of the United States. General Gates was on his march towards Camden, and great hopes were entertained of his being able effectually to relieve the Carolinas and expel the British from all their southern conquests.

Upon the fall of Charleston, says Lee, * many of the leading men of the State of South Carolina sought personal safety with their adherents, in the adjoining states. Delighted at the present prospect, these faithful and * Memoirs of the War in the Southern Department of the United States. 
brave citizens hastened back to their country to share in the perils and toils of war.

Among them were Francis Marion and Thomas Sumter; both colonels in the South Carolina line, and both promoted by Governor Rutledge to the rank of brigadier general in the militia of the state. Marion was about forty-eight years of age, small in stature, hard in visage, healthy, abstemious, and taciturn. Enthusiastically wedded to the cause of liberty, he deeply deplored the doleful condition of his beloved country. The commonweal was his sole object; nothing selfish, nothing mercenary, soiled his ermine character. Fertile in stratagem, he struck unperceived; and retiring to those hidden retreats, selected by himself, in the morasses of Pedee and Black river, he placed his corps not only out of the reach of his foe, but often out of the discovery of his friends.* A rigid disciplinarian, he reduced to practice the justice of his heart; and during the difficult course of warfare, through which he passed, calumny itself never charged

* Lieutenant Colonel Lee was ordered to join Marion after Greene determined to turn the war back to South Carolina in 1781. An officer, with a small party, preceded Lee a few days' march to find out Marion, who was known to vary his position in the swamps of Pedee: sometimes in South Carolina, sometimes in North Carolina, and sometimes on the Black river. With the greatest difficulty did this officer learn how to communicate with the brigadier; and that by the accident of hearing among our friends on the North side of the Pedee, of a small provision party of Marion's being on the same side of the river. Making himself known to this party, he was conveyed to the general, who had changed his ground since the party left him, which occasioned many hours' search even before his own men could find him. 
him with violating the rights of person, property, or of humanity. Never avoiding danger, he never rashly sought it; and acting for all around him as he did for himself, he risked the lives of his troops only when it was necessary. Never elevated with prosperity, nor depressed by adversity, he preserved an equanimity which won the admiration of his friends, and exacted the respect of his enemies. The country from Camden to the seacoast between the Pedee and Santee rivers, was the theatre of his exertions.

Sumter was younger than Marion, larger in frame, better fitted in strength of body to the toils of war, and, like his compeer, devoted to the freedom of his country. His aspect was manly and stern, denoting insuperable firmness and lofty courage. He was not over scrupulous as a soldier in his use of means, and apt to make considerable allowances for a state of war. Believing it warranted by the necessity of the case, he did not occupy his mind with critical examinations of the equity of his measures, or of their bearings on individuals; but indiscriminately pressed forward to his end-the destruction of his enemy and liberation of his country. In his military character he resembled Ajax; relying more upon the fierceness of his courage than upon the results of unrelaxing vigilance and nicely adjusted combination. Determined to deserve success, he risked his own life and the lives of his associates without reserve. Enchanted with the splendor of victory, he would wade in torrents of blood to attain it. This general drew about him the hardy sons of the upper and middle grounds; brave and determined like himself, familiar with diff- 
culty, and fearless of danger. He traversed the region between Camden and Ninety-Six.

A third gentleman quickly followed their great example. Andrew Pickens, younger than either of them, inexperienced in war, with a sound head, a virtuous heart, and a daring spirit, joined in the noble resolve to burst the chains of bondage riveted upon the two southern states, and soon proved himself worthy of being ranked with his illustrious precursors. This gentleman was also promoted by the governor to the station of brigadier general; and having assembled his associates of the same bold and hardy cast, distinguished himself and corps in the progress of the war by the patience and cheerfulness with which every privation was borne, and the gallantry with which every danger was confronted. The country between Ninety-Six and Augusta received his chief attention. These leaders were always engaged in breaking up the smaller posts and the intermediate communications, or in repairing losses sustained by action. The troops which followed their fortunes, on their own or their friends' horses, were armed with rifles; in the use of which they had become expert; a small portion only who acted as cavalry, being provided with sabres. When they approached the enemy they dismounted, leaving their horses in some hidden spot to the care of a few of their comrades. Victorious or vanquished, they flew to their horses, and thus improved victory or secured retreat.

Their marches were long and toilsome, seldom feeding more than once a day. Their combats were like those of the Parthians, sudden and fierce: their deci- 
sions speedy, and all subsequent measures equally prompt. With alternate fortunes they persevered to the last, and greatly contributed to that success, which was the first object of their efforts.

With Marion on his right and Sumter on his left, and General Gates approaching in front, Rawdon discerning the critical event at hand, took his measures accordingly.

He not only called in his outposts, but drew from the garrison of Ninety-Six four companies of light infantry, and made known to Lord Cornwallis the menacing attitude of his enemy.

Sumter's promotion had been the result of one of his brilliant feats. On the 12th of July, 1780, Sumter's little band darted suddenly upon one of these parties, at Williams's plantation, in one of the upper districts of South Carolina. The enemy was taken by surprise, and soon utterly defeated. The sabre did its work eagerly. Scarcely twenty of the bewildered wretches escaped its edge. Captain Huck, one of the most brutal of those who were conspicuous in this warfare, perished in his crimes; and Colonel Ferguson, who was probably the true commander of the party, a good officer, was also among the slain.

This affair, at once brief and brilliant, though on a small scale only, opened equally the eyes of friends and onemies. It was one of the very first, which, after the fall of the metropolis, denoted the reawakening of the spirit of patriotism throughout the state. Sumter's squadron began to receive recruits. In a short time he found himself at the head of six hundred men. Rutledge, 
the governor of South Carolina, promptly acknowledged his spirit and services, by sending him a commission as a brigadier in the service of the state; and assigned to him, as he did to Marion, a certain portion of the country which he was to cover with his protection, and rescue from the enemy.*

Sumter continued his inroads upon the British territory by assaulting, on the first of August, 1780, the post of Rocky Mount, in the charge of Lieutenant Colonel Turnbull, with a small garrison of one hundred and fifty of the New York volunteers and some South Carolina militia. Sumter, attended by the Colonels Lacey, Erwine, and Neale, having each collected some of their militia, repaired, on the 30th of July, to Major Davie, who still continued near the enemy, and was now encamped on the North of the Waxhaw's creek, for the purpose of concerting a joint assault upon some of the British outposts. They were led to hasten the execution of this step, fearing that, by delay, their associates might disperse without having effected any good. After due deliberation they came to the resolution of carrying the posts of Rocky Mount and Hanging rock in succession. The first of these is situated on the west side of the Catawba, thirty miles from Camden, and the last was established on the east side of the same river, twenty-four miles from Camden. They are distant from each other twelve miles.

Sumter having under him three colonels, advanced with the main body upon Rocky Mount. While Major Davie, with his corps and a part of the Mecklenburgh * Washington and the Generals of the American Revolution. 
militia, under Colonel Heaggins, marched to Hanging Rock to watch the motions of the garrison, to procure exact intelligence of the condition of the post, and to be ready to unite with Sumter in the intended blow.

Rocky Mount station is fixed on the comb of a lofty eminence, encircled by open wood. This summit was surrounded with a small ditch and abatis; in the centre whereof were erected three log buildings, constructed to protect the garrison in battle, and perforated with loop holes for the annoyance of the assailants.

As Davie got near to Hanging Rock he learned that three companies of Bryant's loyalists, part of the garrison, were just returning from an excursion, and had halted at a neighboring farm-house. He drew off, determined to fall upon this party. This was handsomely executed, and completely succeeded. Eluding the sentinels in one quarter with his infantry, and gaining the other point of attack with his horse undiscovered, by marching through some adjoining woods, he placed the enemy between these two divisions, each of which pressed gallantly into action.

The royalists, finding their front and rear occupied, attempted to escape in a direction believed to be open, but were disappointed; the Major having detached thither a party of his dragoons in time to meet them. They were all, except a few, killed and wounded; and the spoils of victory were safely brought off, consisting of sixty horses with their trappings, and one hundred muskets and rifles.

Sumter approached Rocky Mount with his characteristic impetuosity; but the British officer was found on 
his guard, and defended himself ably. Three times did Sumter attempt to carry it; but being always foiled, having no artillery to batter down the houses, he drew off undisturbed by the garrison, having lost a few of his detachment, with Colonel Neale, an active, determined, influential officer, and retired to his frontier position on the Catawba. Here he rested no longer than was necessary to recruit his corps, refresh his horses, and provide a part of the provisions necessary to support him on his next excursion. Quitting his retreat with his brave associates, Davie, Irvine, Hill, and Lacey, he darted upon the British line of communications, and fell on the post at Hanging Rock, (6th of August,) which was held by Major Carden with five hundred men, consisting of one hundred and sixty of the infantry of Tarleton's legion, a part of Colonel Brown's regiment, and Bryan's North Carolina corps, a portion of which had, a few days before, been cut to pieces by Major Davie. His attack was, through the error of his guides, pointed at the corps of Bryan, which, being surprised, soon yielded and took to flight. Sumter pressed with ardor the advantage he had gained, and bore down upon the legion infantry, which was forced. He then fell upon Brown's detachment. Here he was received upon the point of the bayonet. The contest grew fierce, and the issue doubtful; but at length the corps of Brown fell back, having lost nearly all its officers and a great proportion of its soldiers.

Hamilton's regiment, with the remains of Brown's, and the legion infantry, now formed in the centre of their position, a hollow square.

Sumter advanced with the determination to strike this 
last point of resistance; but the ranks of the militia had become disordered; and the men scattered from success, and from the plunder of part of the British camp, so that only two hundred infantry, and Davie's dragoons, could be brought into array. The musketry opened; but their fire was ineffectual: nor could Sumter, by all his exertions, again bring his troops to risk close action against his well posted enemy, supported by two pieces of artillery. The cavalry under Davie fell upon a body of the loyalists, who, having rallied, had formed in the opposite quarter, and menaced our right flank. They were driven from their ground, and took shelter under the British infantry still in hollow square.

The spoils of the camp, and the free use of spirits in which the enemy abounded, had for some time attracted and incapacitated many of our soldiers. It was therefore determined to retreat with the prisoners and booty. This was done about twelve o'clock very leisurely in face of the enemy; who did not attempt interruption, so severely had he suffered. A party was now for the first time seen drawn up on the Camden road, with the appearance of renewal of the contest; but on the approach of Davie it fell back. Our loss was not ascertained, from the usual inattention to returns prevalent with militia officers; and many of our wounded were immediately. carried home from the field of battle. The corps of Davie suffered most. Captain M'Clure, of South Carolina, and Captain Reed, of North Carolina, were killed; Colonel Hill, Major Winn, and Lieutenant Crawford, were wounded, as were Captain Craighead, Lieutenant Flenchau, and Ensign M'Clure, of North Carolina. 
The British loss exceeded the Americans. Captain $\mathrm{M}^{\circ}$ Cullock, who commanded the legion infantry with much personal honor, two other officers, and twenty men of the same corps, were killed, and nearly forty wounded. Many officers and men of Brown's regiment were also killed and wounded, and some taken.

Bryan's loyalists were less hurt, having dispersed as soon as pressed. The error of the guides which deranged the plan of attack, the allurement of the spoils found in the enemy's camp, and the indulgence in the use of liquor, deprived Sumter of the victory once within his grasp, and due to the zeal, gallantry, and perseverance of himself and his officers.

Checked but not dismayed, disappointed but not discouraged, Sumter sought his remote asylum to recruit and repair. 


\section{CHA P T E R III.}

Movements of Gates and Rawdon-Gates informed by Sumter of a convoy of stores from Ninety-Six-Sends a reinforcement to him Sumter captures the convoy-Errors of Gates-Cornwallis determines to fight him-His dispositions for battle-Night encounterGates prepares for battle-Battle of Camden-Flight of the militia -Brave resistance of the continentals under Baron De Kalb, and of the North Carolinians--Death of De Kalb.

Aвout this period Gates was advancing near to the scene of action. The American general, soon after he entered South Carolina, directed his march towards Lynch's creek, the southern branch of the Pedee, keeping on his right the friendly and fertile country about Charlotte, the principal town of Mecklenburgh county. Lord Rawdon, unwilling that Gates should find him in Camden, where were deposited his stores, ammunitions, and sick, advanced to a strong position, fifteen miles in front, on the southern banks of Lynch's creek.

This being ascertained by General Gates, he moved to Lynch's opposite to Liord Rawdon; and the two armies remained for four days, separated only by the creek. Gates broke up from this ground inclining to his right, which putting in danger the British advanced force at Rugely's mill, Lord Rawdon directed its evacuation, and fell back to Logstown, in the vicinity of Camden. 21 
Here he became acquainted with the insurrection of the inhabitants on Black river, headed by Brigadier Marion, which, although suspected, it was presumed would have been delayed until the American army should obtain some decisive advantage. Gates, desirous of opening his communication with Sumter, continued to advance upon the North side of Lynch's creek, and took post at Rugely's mill, where he was joined by Brigadier Stevens with seven hundred of the Virginia militia. At the same time he received information from General Sumter that a detachment of the enemy from Ninety-Six, with stores for the main body at Camden, was on its march, which he could conveniently intercept as it passed the ferry on the Wateree, one mile below Camden, if supplied with artillery to batter down a redoubt which covered the ferry. Gates weakened his army, though in striking distance of his foe, by detaching to Sumter four hundred men under the command of Lieutenant Colonel Woolford, of the Maryland line, with two light pieces. As soon as this detachment was put in motion, preparations were made to advance still nearer to Camden.

Meantime Sumter, the moment he received his reinforcement, set off in pursuit of the convoy. Putting his command in motion for Camden ferry, he pushed forward with equal caution and celerity.

Near break of day on the 16th of August, he had approached, undiscovered, to within a few miles of Carey's Ford. The British were taken by surprise. A sudden and impetuous onslaught in Sumter's usual style succeeded, and victory soon declared in his favor. The fort, the stores, troops-ail, were surrendered, and in possession 
of forty-four wagons crammed with valuable stores, together with numerous prisoners, Sumter instantly commenced his retreat with the view of placing his valuable capture beyond the reach of the enemy.

The evacuation of Rugely's mill, and the falling back of Lord Rawdon from Lynch's creek, seem to have inspired General Gates with the presumption that his approach would drive the enemy from Camden. No conclusion more erroneous could have been drawn from a fair view of the objects and situation of the respective armies.

The British general was under the necessity of maintaining his position; for retreat yielded up that country which he was bound to retain, and encouraged that spirit of revolt which he was bound to repress. All the disposable force under his orders had been concentrated at Camden; delay would not thicken his ranks while it was sure to add to those of his adversary. Every consideration urged the British general to battle; and no commander was ever more disposed than Lord Cornwallis to cut out relief from embarrassment by the sword. The foundation of the policy pursued by General Gates, was laid in error; and we ought not to be surprised at its disastrous termination. Had Gates not confidently presumed that a retrogade movement on the part of the enemy would have.been the effect of his advance, he certainly would have detained Woolford's detachment, and ordered Sumter to join him; it being unquestionable that victory in the plains of Camden would give to him the British army, and with it all the posts in South Carolina except Charleston. To this end his means 
ought to have been solely directed; or if he preferred the wiser course, to spin out the campaign condensing his main body, and beating the enemy in detail, he should have continued in his strong position behind Lynch's creek, ready upon Cornwallis's advance to have fallen back upon its head waters, in the powerful and doubtful counties of Cabarrus, Rowand, and Mecklenburgh,*

No doubt General Gates was unfortunately persuaded that he had nothing to do but to advance upon his enemy, never supposing that, so far from retiring, the British general would seize the proffered opportunity of battle.

Unhappily for America, unhappily for himself, he acted under this influence, nor did he awake from his reverie until the proximity of the enemy was announced by his fire in the night, preceding the fatal morning.

Lord Cornwallis having been regularly informed of the passing occurrences, hastened to Camden, which he reached on the 13th; spending the subsequent day in review and examination, he found his army very much enfeebled; eight hundred being sick, his effective

* The inhabitants of these three counties, among the most populous in the state, were true and zealous in their maintenance of the revolution; and they were always ready to encounter any and every peril to support the cause of their hearts. Contiginous to the western border over the mountains, lived that hardy race of mountaineers. equally attached to the cause of our common country, and who rolled occasionally like a torrent on the hostile territory. The ground was strong, and the soil rich and cultivated. In every respect, therefore, it was adapted to the American general until he had rendered himsclf completely ready for defence. 
strength was reduced to somewhat less than two thousand and three hundred men, including militia, and Bryan's corps, which together amounted to seven hundred and fifty men. Judging from the exertions of Congress and the States of Virginia and North Carolina, by their publications, he rated his enemy at six thousand; in which estimation his lordship was much mistaken, as from official returns on the evening preceding the battle, it appears that the American force did not exceed four thousand, including the corps detached under Lieutenant Colonel Woolford; yet there was a great disparity of numbers in our favor; but we fell short in quality, our continental horse, foot, and artillery, being under one thousand, whereas the British regulars amounted to nearly one thousand and six hundred.

Notwithstanding his diminished force, notwithstanding the vast expected superiority of his enemy, the discriminating mind of the British general paused not an instant in deciding upon his course.

No idea of a retrogade movement was entertained by him. Victory only could extricate him from the surrounding dangers; and the quicker the decision the better his chance of success. He therefore gave orders to prepare for battle, and in the evening of the $15 \mathrm{th}$, put his army in motion to attack his enemy next morning in his position at Rugeley's mill.

Having placed Camden in the care of Major M'Arthur, with the convalescents, some of the militia, and a detachment of regulars expected in the course of the day, he moved, at the hour of ten at night, in two divisions. The front division, composed of four companies 
of light infantry, with the twenty-third and thirtythird regiments, was commanded by Lieutenant Colonel Webster.

The rear division, consisting of the legion infantry, Hamilton's regiment of North Carolinians, the volunteers of Ireland, and Bryan's corps of loyalists, was under the orders of Lord Rawdon. Two battalions of the seventy-first, with the legion cavalry, formed the reserve.

After Gates had detached Woolford to Sumter, and prepared his army to move, it was resolved in a council of war to march on the night of the 15th, and to sit down behind Saunders's creek, within seven miles of Camden. Thus it happened that both the generals were in motion at the same hour, and for the same purpose: with this material distinction, that the American general grounded his conduct in his mistaken confidence of his adversary's disposition to retreat; whereas, the British commander sought for battle with anxiety, regarding the evasion of it by his antagonist as the highest misfortune.

Our baggage, stores, and sick, having been sent off to the friendly settlement of the Waxhaws, the army marched at ten o'clock at night. Armand's * legion, in horse and foot not exceeding one hurıdred, moved as

* Armand was one of the many French gentlemen who joined our army, and was one of the few who were honored with important commands. His officers were generally foreign, and his soldiers chiefly deserters. It was the last corps in the army which ought to be entrusted with the van post; because, however, unexceptionable the officers may have been, the materials of which the corps was composed did not warrant such distinction. 
a van guard, flanked by Lieutenant Colonel Porterfield's corps on the right, and by Major Armstrong's light infantry, of the North Carolina militia, on the left. The Maryland and Delaware lines composed the front division, under Baron de Kalb; the Militia of North Carolina, General Caswell, the centre; and the Virginia militia under Brigadier Stevens, the rear. Some volunteer cavalry were placed to guard the baggage. Midway between Camden and Rugeley's mill, the two armies met, about one in the morning. They instantly felt each other; when the corps of Armand shamefully turned its back, carrying confusion and dismay into our ranks. The leading regiment of Maryland was disordered by this ignominious flight; but the gallant Porterfield, taking his part. with decision on the right, seconded by Armstrong on the left, soon brought the enemy's van to a pause. Prisoners being taken on both sides, the adverse generals became informed of their unexpected proximity.*

* Mr. Marshall, in his life of Washington, gives a summary of the principal events in the southern war. This faithful historian tells us, that in the night, as soon as the skirmish terminated, some prisoners were brought to Gates; from whom he learnt that the British army was in front. The general officers were immediately assembled. The intelligence received from the prisoners was communicated to them, and their opinions asked on -the measures to be adopted.

General Stevens, of the Virginia militia, answered, that "It was now too late to retreat." A silence of some moments ensued ; and General Gates, who seems himself to have been disposed to try the chance of a battle, understanding silence to be an approbation of the sentiments delivered by Stevens, broke up the council by saying, "Then we must fight, gentlemen, please to take your posts." 
The two armies halted, each throbbing with the emotions which the van rencontre had excited. The British army displayed in one line, which completely occupied the ground, each flank resting on impervious swamps. The infantry of the reserve took post in a second line, one half opposite the centre of each wing; and the cavalry held the road, where the left of the right wing united with the volunteers of Ireland, which corps formed the right of the left wing. Lieutenant Colonel Webster commanded on the right, and Colonel Lord Rawdon on the left. With the front line were two six and two three pounders, under Lieutenant M'Leod of the artillery; with the reserve were two six pounders. Thus arranged, confiding in discipline and experience, the British general waited anxiously for light.

The Maryland leading regiment was soon recovered from the confusion produced by the panic of Armand's cavalry. Battle, although unexpected, was now inevitable; and General Gates arrayed his army with promptitude. The second brigade of Maryland, with the regiment of Delaware, under General Gist, took the right; the brigade of North Carolina militia, led by Brigadier Caswell, the centre; and that of Virginia, under Brigadier Stevens, the left. The first brigade of Maryland was formed in reserve, under the command of General Smallwood, who had on York Island, in the beginning of the war, when colonel of the first regiment of Maryland, deeply planted in the hearts of his country the remembrance of his zeal and valor, conspicuously displayed in that the first of his fields. To each brigade a due proportion of artillery was allotted; 
but we had no cavalry, as those who led in the right were still flying. Major General Baron de Kalb, charged with the line of battle, took post on the right; while the general in chief, superintending the whole, placed himself on the road between the line and the reserve. The light of day dawned,-the signal for battle. Instantly our centre opened its artillery, and the left of our line, under Stevens, was ordered to advance. The veterans of the enemy, composing its right, were of course opposed to the Virginia militia; whereas they ought to have been faced by the continental brigade.* Stevens, however, exhorting his soldiers to rely on the bayonet, advanced with his accustomed intrepidity. Lieutenant Colonel Otho Williams, Adjutant General, preceded him with a band of volunteers, in order to invite the fire of the enemy before they were in reach of the militia, that experience of its inefficacy might encourage the latter to do their duty. The British general, closely watching our motions, discovered this movement on the left, and gave orders to Webster to lead into battle with the right. The command was executed with the characteristic courage and intelligence of that officer. Our left was instantly overpowered by the assault; and the brave Stevens had to endure the mortifying spectacle, exhibited

* General Gates did not, in his disposition, conform to the judi. cious principle which we find observed by General Lincoln; or our continentals would have been posted on the left to oppose the British right. Indeed, such seems to have been Gates' hurry, from the moment he was called to the command of the south, as to forbid that full inquiry into his enemy's and his own situation, as well as intimate acquaintance with the character of his own and his enemy's troops, so necessary to the pursuit of right measures in war. 
by his flying brigade. Without exchanging more than one fire with the enemy, they threw away their arms; and sought that safety in flight, which generally can be obtained only by courageous resistance. The North Carolina brigade, imitating that on the right, followed the shameful example. Stevens, Caswell, and Gates himself, struggled to stop the fugitives, and rally them for battle; but every noble feeling of the heart was sunk in base solicitude to preserve life; and having no cavalry to assist their exertions, the attempted reclamation failed entirely. 'The continental troops, with Dixon's regiment of North Carolinians, were left to oppose the enemy; every corps of whose army was acting with the most determined resolution. De Kalb and Gist yet held the battle on our right in suspense. Lieutenant Colonel Howard, at the head of Williams's regiment, drove the corps in front out of line. Rawdon could not bring the brigade of Gist to recede:-bold was the pressure of the foe; firm as a rock the resistance of Gist. Now the Marylanders were gaining ground; but the deplorable desertion of the militia having left Webster unemployed, that discerning soldier detached some light troops with Tarleton's cavalry in pursuit, and opposed himself to the reserve brought up by Smallwood to replace the fugitives. Here the battle was renewed with fierceness and obstinacy. The gallant Marylanders, with Dixon's regiment, although greatly outnumbered, firmly maintained the desperate conflict; and De Kalb, now finding his once exposed flank completely shielded, resorted to the bayonet. Dreadful was the charge! In one point of the line the enemy were driven before us 
with the loss of many prisoners. But while Smallwood covered the flank of the second brigade, his left became exposed; and Webster, never omitting to seize every advantage, turned the light infantry and twenty-third regiment on his open flank. Smallwood, however, sustained himself with undiminished vigor; but borne down at last by superiority of force, the first brigade receded. Soon it returned to the line of battle;-again it gave ground, and again rallied. Meanwhile De Kalb, with our right, preserved a conspicuous superiority. Lord Cornwallis, sensible of the advantages gained, and aware of the difficulty to which we were subjected by the shameful flight of our left, concentrated his force and made a decisive charge. Our brave troops were broken; and his lordship, following up the blow, compelled the intrepid Marylanders to abandon the unequal contest. To the woods and swamps, after performing their duty valiantly, these gallant soldiers were compelled to fly. The pursuit was continued with keenness, and none were saved but those who penetrated the swamps which had been deemed impassable. The road was heaped with the dead and wounded. Arms, artillery, horses, and baggage, were strewed in every direction; and the whole adjacent country presented evidences of the signal defeat.

Our loss was very heavy. More than a third of the continental troops were killed and wounded; and of the wounded one hundred and seventy were made prisoners. The regiment of Delaware was nearly annihilated; and Lieutenant Colonel Vaughn and Major Patton being taken, its remnant, less than two companies, was after- 
wards placed under the orders of Kirkwood, senior Captain. The North Carolina militia also suffered greatly; more than three hundred were taken, and nearly one hundred killed and wounded. Contrary to the usual course of events and the general wish, the Virginia militia, who set the infamous example which produced the destruction of our army, escaped entirely.

De Kalb, sustaining by his splendid example the courageous efforts of our inferior force, in his last resolute attempt to seize victory, received eleven wounds, and was made prisoner. His yet lingering life was rescued from immediate death by the brave interposition of Lieutenant Colonel Du Buysson, one of his aids-de-camp; who, embracing the prostrate general, received into his own body the bayonets pointed at his friend. The heroic veteran, though treated with every attention, survived but a few days. Never were the last moments of a soldier better employed. He dictated a letter to General Smallwood, who succeeded to the command of his division, breathing in every word his sincere and ardent affection for his officers and soldiers; expressing his admiration of their late noble though unsuccessful stand; reciting the eulogy which their bravery had extorted from the enemy; together with the lively delight such testimony of their valor had excited in his own mind, then hovering on the shadowy confines of life. In this endearing adicu he comprehended Lieutenant Colonel Vaughn, with the Delaware regiment and the artillery attached to his division; both of which corps had shared in the glory of that disastrous day. Feeling the pressure of death, he stretched out his quivering hand 
to his friend Du Buysson, proud of his generous wounds; and breathed his last in benedictions on his faithful, brave division. We lost, besides Major General Baron de Kalb, many excellent officers ; and among them Lieutenant Colonel Porterfield, whose promise of future greatness had endeared him to the whole army. Wounded in his brave stand in the morning, when our dragoons basely fled, he was taken off the field, never more to draw his sword! Brigadier Rutherford, of the North Carolina militia, and Major Thomas Pinkney, of the South Carolina Line, aid-de-camp to General Gates, were both wounded and taken.

The British loss is stated to have amounted to eighty killed, and two hundred and forty-five wounded.*

* Lee's Memoirs. 


\section{H A P TER IV.}

Gates informed of Sumter's success--Movements of Major Darie-

He informs Sumter of Gates's defeat-Sumter retreats rapidlyPursued and surprised by Tarleton-Sumter escapes with part of his force-Comments on 'Tarleton's conduct-Gates retires to Salisbury-Afterwards to Hillsborongh.

In the midst of this heart-rending defeat, General Gates received advice of the success of Sumter against the British convoy. Some consolation* was thus administered to his wounded spirit. The corps under Sumter, added to those who had escaped this day of destruction, would have formed a force which could preserve

* This consolation was necessarily mingled with acute remorse. It must have reminded the general of the advantages once in his command, by pursuing the prudent system of striking his adversary in detail ; and if victory with him was ouly pleasant by being immediate, it would bring to his recollection the propriety of having brought Sumter to him, instead of detaching Woolford from him.

Lord Cornwallis, hearing from his commander at Camden of the success of Sumter, in the midst of his prosperity turned his mind to the recovery of the loss he had sustained,-an example meriting imitation from all who may command in war. Small as was the advantage gained, had it been enjoyed, great would have been the good derived in its consequences. The British general, foreseeing this, did not indulge even in the proud moments of victory, but gave his mind and time to prepare Sumter's destruction. 
the appearance of resistance, and give time for the arrival of succor. Major M'Arthur, about the same time, communicated the occurrence to Lord Cornwallis; who occupied his first moments after his victory in despatching orders to Lieutenant Colonel Turnbull, then stationed on Little river with the New York volunteers, and Major Ferguson's corps of loyalists, to intercept General Sumter and bring him to action.

Major Davie's corps, part of the force under Sumter, in his preceding operations, had suffered severely on the 6 th of August, in the unsuccessful attempt on the post at Hanging Rock; and was subsequently engaged in escorting our wounded to Charlotte, where Davie had previously established a hospital. The moment this service was performed, Major Davie hastened to the general rendezvous at Rugeley's mill.

On the fifteenth, arriving after Gates had moved, he followed the army; and marching all night, met the first part of our flying troops about four miles from the field of battle. With an expectation of being useful in saving soldiers, baggage, and stores, he continued to advance; and meeting with Brigadier General Huger, of the South Carolina line, driving his tired horse before him, he learnt the probability of Sumter's ignorance of the defeat of our army, and of the consequent danger to which he would be exposed. Major Davie therefore instantly despatched Captain Martin, attended by two dragoons, to inform Sumter of this afflicting event; to urge him to take care of his corps by immediate retreat, and to request him to repair to Charlotte, whither him- 
self meant to proceed, and assemble, as he returned, all the force which could be induced to take the field.

On the night following, Captain Martin reached Sumter, who immediately decamped with his prisoners and Dooty. Turnbull's attempt failed, from the celerity with which Sumter had moved. Apprehensive that Sumter might escape Turnbull, and anxious to break up this corps, the British general was not satisfied with a single effort to destroy him; and, on the same evening, directed Lieutenant Colonel Tarleton, with his legion and some light infantry, to proceed in the morning from the field of battle across the Wateree in pursuit of that enterprising officer.

Having avoided Turnbull, Sumter seems to have indulged a belief that he was safe; and accordingly encamped on the night of the 17th at Rocky Mount, about thirty miles from Camden, and much nearer Cornwallis. To halt for the night within striking distance of the British army was evidently improvident. After a few hours rest, he ought certainly to have renewed his march. At daylight, he did, indeed, resume it; but, having passed Fishing creek, eight miles distant, he again halted. His troops occupied, in line of march, a ridge contiguous to the north side of the creek, at which place his rear guard was stationed; and two videts were posted at a small distance in its front. Confiding in this hazardous situation, to these slender precautions, his arms were stacked, the men were permitted to indulge at pleasure; some in strolling, some bathing, and others reposing. The troops, no doubt, were extremely wearied; but bodily debility does not warrant inattention in a com- 
mander. it snould redouble his caution and exertion. If the halt at Fishing creek was unavoidable, the troops least fatigued and best armed should have been selected and posted for combat, while those most fatigued, snatched rest and food. With this alternate relief the retreat ought to have been continued; and the corps would have been saved.

Lieutenant Colonel Tarleton moved with his accustomed velocity; and after a rapid march on the 17 th, approached Sumter's line of retreat. Finding many of his men and his horses too much exhausted to proceed with the requisite despatch, he left behind more than half of his force, and pressed forward with about one hundred and sixty. Passing the Catawba at Rocky Mount ford, he got into Sumter's rear, whose precautions for security were readily eluded. The enemy reached him unperceived, when consternation at the unlooked-for assault became general. Partial resistance was attempted, but soon terminated in universal flight. Sumter's force, with the detachment under Lieutenant Colonel Woolford, was estimated at eight hundred: some were killed, others wounded, and the rest dispersed. Sumter himself fortunately escaped, as did about three hundred and fifty of his men; leaving two brass pieces of artillery, arms, and baggage, in possession of the enemy, who recovered their wagons, stores, and prisoners.*

* The officer adventuring, as did General Sumter, must never be satisfied with common precautions : they will not do.

It is difficult to prescribe rules upon the subject; because every single case is to be regarded, and must suggest its own regulations to a meditating mind. One fixed principle however we may venture 22 
In this enterprise, although fortunate in its issue, Lieutenant Colonel Tarleton evinced a temerity, which could not, if pursued, long escape exemplary chastisement. Had Sumter discovered his approach, that day would at least have arrested his career, if it had not closed his existence. But unhappily for America, her soldiers were slaughtered, sometimes from the improvidence of their leaders, more often from their own fatal neglect of duty and disobedience of orders. Vain is it to place guards around your camp, and videts in their front, if, unmindful of the responsibility of their stations, they indulge in repose, or relinquish their posts. The severe consequences of such criminal neglect, we may suppose, would prevent the repetition of the evil; but soldiers are not to be corrected by their own observations or deductions. Rewards and punishments must be added; and execution on the spot, of a faithless or negligent sentinel, is humanity in the end. Militia will not endure this rigor, and are therefore improperly intrusted with the sword of the nation in war. The pursuance of that system must weaken the best resources of the state, by throwing away the lives of its citizens; and those rulers must provoke the vengeance of Heaven, who

to lay down : viz., that the captured, with a portion of the victorious corps, ought to be immediately despatched, with orders to move night and day until out of reach; while the commander, with the least fatigued troops, should hold himself some few hours in the rear, sweeping with the best of his cavalry all the country between him and his enerny, thus procuring correct information, which will always secure a retiring corps. 
invite such destruction, by adhering to this impotent policy.

The tragedy of the 16th closing with the catastrophe of the 18th, the army of the South became a second time nearly annihilated. General Gates halted at Charlotte, where some of his defeated army had arrived. Soon after he retired to Salisbury, and afterwards to Hillsborough, one hundred and eighty miles from Camden; where he determined to collect his scattered forces, and to draw reinforcements, with a resolution of again facing his successful adversary.* Smallwood and Gist continued at Salisbury, until all the dispersed continentals were assembled. The militia of both states passed on towards their respective homes, selecting their own route, and obtaining subsistence from the charity of the farmers on the road.

* This rapid withdraw of General Gates has been generally supposed to diminish his reputation. Not so, in truth. It does him honor; as it evinced a mind capable, amidst confusion and distress, of discerning the point most promising to renew with expedition his strength: at the same time incapable of being withheld from doing his duty, by regarding the calumny with which he was sure to be assailed. 


\section{CHAPTER V.}

Sumter again in the field-Operations of the parties and leaders in the South-Position of the British army-Operations of Marion and Sumter-Tarleton foiled by Marion-Major Wemyss defeated by Sumter-Tarleton sent against Sumter-Battle of Blackstock Hill-'Total defeat of Tarleton by Sumter-Sumter severely wounded and compelled to quit active service-Operations of Marion-State of the Southern country.

IN three days after Sumter's disastrous defeat at Fishing creek, as related in the last chapter, he had collected his fugitive men, was reinforced by volunteers, and had made a stand at Sugar creek.

Although when the defeat of Gates at Camden was effected, there was no regular army in South Carolina for three months, Sumter with his small irregular force maintained a constant warfare with the enemy, and kept up the spirit of liberty in the country in the neighborhood of Broad river. He crossed that stream, and by rapid marches ranged the country between the Ennoree and Tyger rivers, in the neighborhood of the Broad. His men were all mounted. They would strike a blow in one place to-day; to-morrow their power would be felt at a point far distant. Marion and Pickens were engaged in a similar service in the lower country; while 
Clarke and Twiggs of Georgia, and Williams of NinetySix were equally active.

Meantime, on the 29th of October, the British army reached the country lying between Camden and NinetySix.

To support these two stations, and to shield the intermediate space from American incursions, Cornwallis established himself at Winnsborough, a position very convenient for the purposes contemplated. Here he desired to repose in quiet until the junction of the detachment from Virginia, under Leslie, should enable him to resume his operations in North Carolina. But Marion and Sumter continuing unchanged amid the despondency which the disasters of August had produced, boldly pushed their disturbing inroads into the enemy's territory. With a force fluctuating from fifty to two hundred and fifty men, Marion held himself in his recesses on the Pedee and Black rivers; whence he darted upon the enemy whenever an opportunity presented. He not only kept in check all the small parties of the enemy, whom the want of forage and provisions, or the desire of plunder, occasionally urged into the region east and south of Camden; but he often passed the Santee, interrupting the communication with Charleston, and sometimes alarming the small posts in its vicinity. To such a height had his interruption reached, that Cornwallis turned his attention to the subject. Lieutenant Colonel Tarleton was despatched with his legion and the light artillery, with orders to find out Marion's haunts, and to destroy him. Having passed the Santee and approached the Black river, this officer exerted 
himself to bring Marion to action; but the American partisan, having ascertained the very superior force of his adversary, acted so as to elude all the attempts made to entrap him.

At length Tarleton contrived, by his manœurres, to circulate an opinion that, by detachments from his corps, he had very much reduced his force. This rumor, as was intended, soon reached Marion, who was always willing to seize every opportunity of striking at his antagonist. Presuming that Tarleton was reduced to an equality with himself, he cheerfully relinquished his occult asylum, wishing to give battle to his adversary. His caution and vigilance were not intermitted; and, discovering that he was proceeding upon erroneous intelligence, he skillfully withdrew to his unassailable position, leaving Tarleton to deplore the inefficacy of his wiles and toils.

While Marion engaged the attention of Cornwallis, whose cavalry and artillery were drawn to the east of the Santee, Sumter hovered on the west of that river, searching for some vulnerable point to assail. This officer, equally indefatigable and enterprising with his compeer, had the mountainous country of the Carolinas to draw upon for assistance. He had therefore, the advantage of Marion in numbers; sometimes commanding five hundred, and at others eight hundred, men. When Lord Cornwallis became acquainted with the approach of Sumter, Major Wemyss was detached in pursuit of him, with the sixty-third regiment, and the remains, about forty in number, of the legion cavalry. 
The American general having displayed, on past occasions, a character of more boldness than vigilance, the British officer was inspired with a hope of surprising him; and directed his march, with great secrecy, to Broad river, where Sumter was encamped. The silent celerity with which Wemyss advanced, brought him, sooner than he intended, to the vicinity of his enemy; and, apprehending that Sumter might be apprised, before morning, of his proximity, he determined on a nocturnal attack. His corps was immediately formed for battle, and advanced on Sumter's camp. Anxious to observe the condition of his foe, Major Wemyss placed himself with the van officer, who soon fell on our piquet and threw them back on the main body, after a feeble resistance. Only five muskets were discharged; and, happily for us, two balls pierced the major, and disabled him from further exertion. The command devolved upon a subaltern, who, although unacquainted with the ground, and uninformed as to the plan, determined to press the attack. He found Sumter prepared to receive him; and very soon the contest terminated in the repulse of the British, who retired, leaving their commandant and twenty men on the ground.*

* Major Wemyss was very remiss in not having opened his plau and views to his second in command; for it often happens that the first is stopped from service during the action. What might have been the issue of this enterprise had the British major properly informed his next in command with his plan, resources, and expectations, cannot be determined; but no doubt can exist but that the effect of the assailing troops must have been diminished considerably by this culpable omission in the commandant. 
344 LIFE OF MAJOR GENERAL THOMAS SUMTER.

The American officer, satisfied with his success, did not pursue it; but crossed the Broad river, for the purpose of proceeding to the chief object of his expedition. He had concerted, with Colonels Clarke and Banner, who commanded bands of mountaineers, measures for surprising Ninety-six. To cover that enterprise, he menaced Camden; intending by a forced march, to join Clarke and Banner on the west side of the Broad river.

On the day following a junction was effected; and Sumter, at the head of the combined forces, proceeded to the execution of his design. These occurrences excited in Lord Cornwallis apprehensions for the safety of Ninety-six. Orders were instantly despatched, recalling Tarleton from his expedition against Marion, and directing him to proceed without delay against Sumter. The sixty-third regiment which had not yet returned from its unsuccessful enterprise, was ordered to join Tarleton as he advanced. As soon as that officer received the order of Cornwallis, he left his position in the vicinity of Black river, and hastened towards Ninety-six.

Accustomed to quick movements, he arrived in the neighborhood of Sumter, before the latter had even heard of his advance. Pushing up the Ennoree river, Tarleton hoped to place himself in his enemy's rear; but, luckily, a deserter from the British infantry had apprised the American general of his adversary's movements.

Sumter immediately drew off and passed the Ennoree, where the British van overtook a part of his rear guard, and handled it roughly. Sumter continued to retreat, 
having the Tyger, one of the most rapid and obstructive rivers of that country, in his front. Tarleton, foreseeing that should his adversary pass the Tyger, there would be little prospect of bringing him to action, redoubled his exertions to overtake him. Well knowing the character of his foe, he had preserved his force in a compact order; but his apprehension that Sumter might escape, his ardor in pursuit, and desire to continue the success with which his zeal had been generally crowned, impelled him to deviate from that prudent course.

In the evening of the 20 th of November, at the head of his cavalry, about one hundred and seventy in number, and eighty mounted infantry, of the sixty-third regiment, he dashed forward to bring Sumter to battle, before the latter had passed the Tyger; and soon came in sight of his enemy, who had selected a strong position on Blackstock hill, on the eastern banks of the river.

Here prudence would have dictated to Colonel Tarleton a pause. The residue of the sixty-third regiment, the legion and light infantry, were following with all possible dispatch; and in one hour might have joined him. There was no possibility of his enemy's escape without battle; and the co-operation of his infantry was indispensable to secure victory. But delay did not comport with the ardent zeal or experience of Tarleton; and he boldly advanced to the assault.

"That part of the hill," says M'Kenzie, in his Strictures on the Campaigns of Tarleton, "to which the attack was directed was nearly perpendicular, with a small rivulet, brushwood, and a rail fence in front. The rear of the Americans, and part of their right flank, was se- 
cured by the river Tyger; and their left was covered by a large iog barn, into which a considerable division of their force had been thrown, and from which, as the apertures between the logs served them for loop holes, they fired with security. British valor was conspicuous in this action; but no valor could surmount the obstacles that here stood in its way. Of the sixty-third regiment, the commanding officer, two others, and one third of the privates, fell.*

"Lieutenant Colonel Tarleton, observing their situation, charged with his cavalry; but, unable to dislodge the enemy, either from the log barn on his right, or the height on his left, he was obliged to fall back. Lieutenant Skinner, with a presence of mind ever useful on such emergencies, covered the retreat of the sixty-third; and in this manner did the whole party continue to retire, till they formed a junction with their infantry, who were advancing to support them, leaving Sumter in quiet possession of the field.

"Sumter occupied the ground for several hours; but having received a severe wound, and knowing that the British would be reinforced before next morning, he

* Major Money, Lieutenant Gibson, Lieutenant Cope : the infantry amounted only to eighty. What presumption! to expect to dislodge an officer acknowledged to be the most brave, posted on ground chosen by himself, at the head of five or six hundred troops, whose valor had been often before tested, with one hundred and sixty, mostly dragoons. The British cavalry could not act with effect from the nature of the ground, as was evinced by the nugatory attempt made by Lieutenant Colonel Tarleton at their head. 
thought it hazardous to wait. He accordingly retired,* and taking his wounded men along with him, crossed the rapid river Tyger. The wounded of the British detachment were left to the mercy of their enemy; and it is doing but bare justice to General Sumter to declare that the strictest humanity took place upon the present occasion: they were supplied with every comfort in his power." This faithful and plain relation was made from the representations of officers in the action.

Lieutenant Colonel Tarleton, however, viewed his own conduct in the most favorable light; and not only considered the assault warrantable, but even claimed the victory. If the principle, on which his pretension is founded, be correct, nothing short of exterminating success can give title to victory. What more could the assailed party have done than to fight, to retain his ground, bury the dead, and take care of the enemy's wounded? Of his own wounded, General Sumter had but four to take care of, and of his own dead, but three to bury. But he did not wait until Colonel Tarleton might return with a superior force; and as Tarleton did return and occupy the field of battle on the day following, therefore Tarleton was the victor. Such logic does not merit refutation. But, however interested military disputants may contest the point, impartial posterity will concur in the conclusion of common sense, that Sumter gained a decisive victory. A grievous wound suspended his personal exertions, and probably

* Tradition says that Sumter's wound was so severe that he had to be placed in a litter made of a new ox hide and carried on the shoulders of his men. 
preverited him from improving his success. After performing the funeral rites of the dead, and placing the wounded of the enemy in the most comfortable condition in his power, he continued his retreat. His faithful associates, agreeably to usage, separated as soon as they reached their point of safety.

Sumter's wound, unfortunately for his country, long detained him from the field; but useful consequences continued to result from the deep impression of his example, from the spirit he had infused, and the experience gained under his guidance. Pickens, Harden, Clarke, and others, persevered in their arduous exertions. Frequently interrupting the communication between the different posts of the enemy, they obliged the British general to strengthen his stations, spread throughout the country, and thereby weaken his operative force.

Tarleton was no sooner recalled from the east of the Santee, than Marion emerged from his concealed retreat, traversed the country from Georgetown to Camden, and endangered the communication between them. Frequently crossing the Santee, he interrupted the intercourse between Charleston and Camden; to secure which, an intermediate post had been established at Matte's hill, on the south side of the Congaree.

Thus, in this gloomy period, was resistance in the South continued; as embarrassing to the enemy, as exhilarating to the scattered refugees from South Carolina and Georgia. It produced in Congress and the 
nation a solacing conviction, that the spirit of the peo- ple was not subdued; and promised, if seconded with vigor, and directed with wisdom, to restore the two lost States to the Union.*

$$
\text { * Lee's Memoirs. }
$$


CHAPTER VI.

General Sumter receives the thanks of Congress for his servicesWhat Cornwallis said of him--Sumter again takes the field-Destroys the magazines of Fort Granby-Retreats-Captures an escort with wagons and stores-Advances to Fort Watson-Retires on the approach of Lord Rawdon-Defeats Major FraserRaises three regiments of regulars-Service of that force-Sumter in the State Convention-In Congress-His retirement from public life-His death.

ON the 13th of January, 1781, Congress passed a very complimentary resolution of thanks to General Sumter and his men, in the preamble of which, his victory at Hanging Rock, and his defeat of Wemyss and Tarleton, are particularly mentioned.

Soon after the battle at Blackstock hill, Cornwallis, writing to Tarleton, said, "I shall be very glad to hear that Sumter is in a condition to give us no further trouble. He certainly has been our greatest plague in this country." This is a very high testimony to Sumter's transcendent abilities as a partisan. No one knew better than Lord Cornwallis, how much injury Sumter had inflicted on the enemies of his country.

After the battles fought by General Greene, and the departure of Cornwallis for Virginia, General Sumter, who had just recovered from his wound, collected ano- 
ther force, and early in February, 1781, crossed the Congaree and destroyed the magazines of Fort Granby.

On the advance of Lord Rawdon from Camden, Sumter retreated-and immediately menaced another British post. Two days after, he defeated an escort of the enemy, and captured the wagons and stores which they were conveying from Charleston to Camden. He next, with two hundred and fifty horsemen, swam across the Santee, and advanced on Fort Watson, but retreated on the approach of Lord Rawdon to its relief. On his return to Black river he was attacked by Major Fraser with a very large force. Fraser lost twenty men and retreated. Having thus cheered the spirits of the people of the centre of the state, he retired to the borders of North Carolina. In March, 1781, he raised three regiments of regulars. His previous enterprises had all been executed by militia. He subsequently took part in the military movements in the lower country, until the close of the war, and co-operating with Marion, struck many successful blows at the British, and was distinguished in the several actions which were fought between Orangeburgh and Charleston.*

After the peace, General Sumter was a distinguished member of the State Convention, in which he voted with those who opposed the adoption of the Federal Constitution, on the ground that the states were not sufficiently

* For details of Sumter's services with the regular force under his command, the reader is referred to the 18th chapter of the Life of General Lee, in the former part of this volume. This force was engaged in the battle of Eutaw. But before that action, Sumter bad left the army, the war being then virtually at an end, and the enemy beaten. 
shielded by it against federal usurpation. He was afterwards selected one of the five members from that state in the House of Representatives of the first Congress under the Constitution, and continued to represent South Carolina in the House of Representatives, and afterwards in the Senate, until 1808. He took an active part with the other members from that state, in denouncing a petition for the abolition of slavery, which was presented from the Quakers of Pennsylvania.

For many years the veteran patriot lived in retirement amid the respect and affection of his neighbors. He retained his fine spirit unbroken to the end, and at the age of nearly a hundred years exhibited the cheerfulness and fire of youth. But a few weeks before his death, he vaulted into his saddle with the activity of a young man, and the faculties of the mind retained their vigor as well as those of the body. He died at his residence, South Mount, South Carolina, on the first of June, 1832, at the advanced age of ninety-seven. 


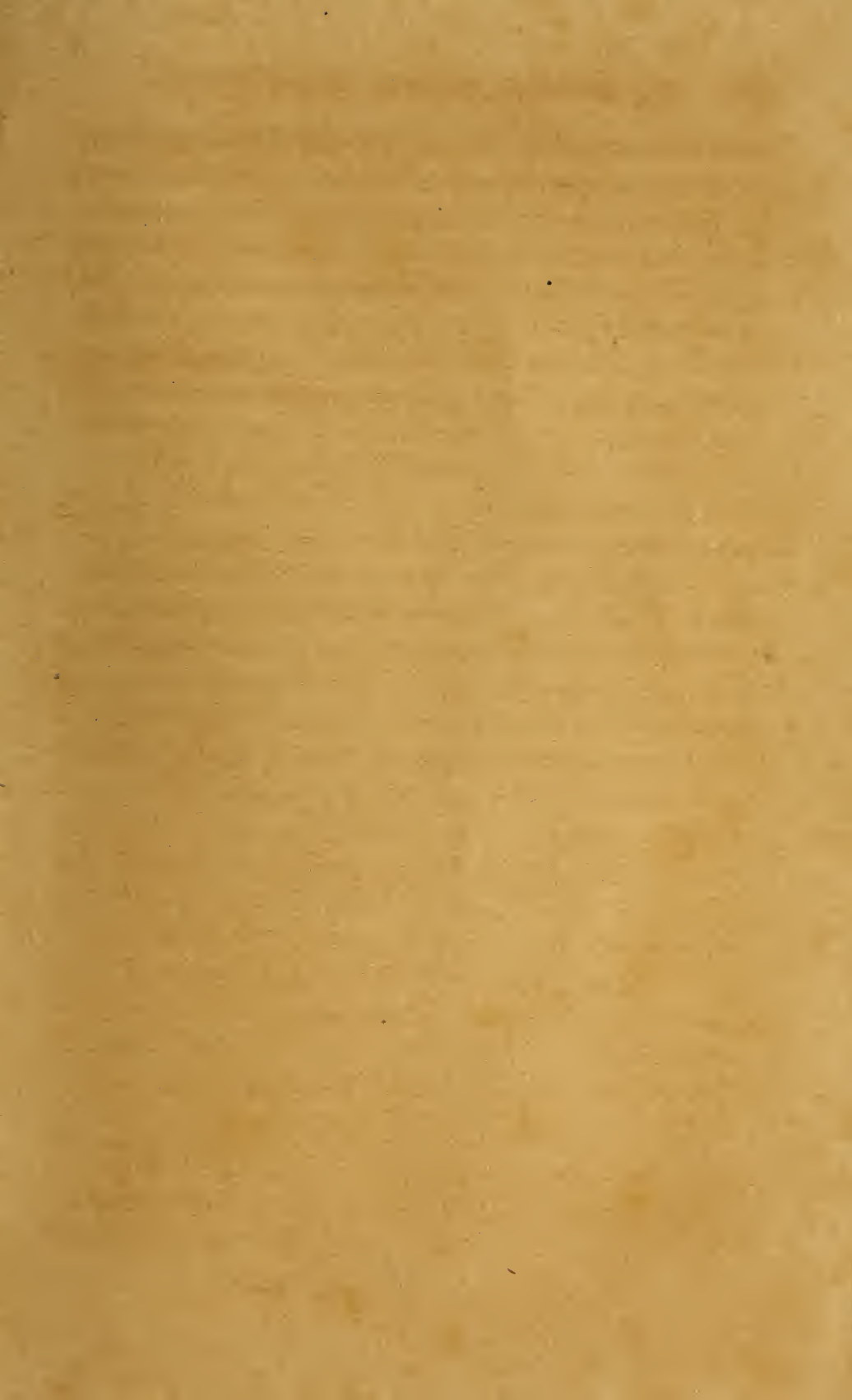






